\title{
Early Paleozoic Brachiopods of the Moose River Synclinorium, Maine
}

GEOLOGICAL SURVEY PROFESSIONAL PAPER 784

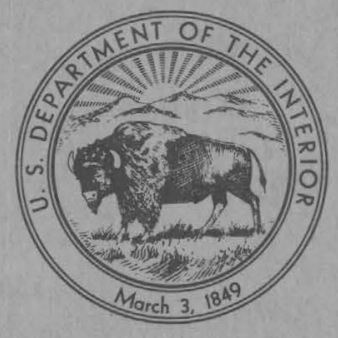





\section{Early Paleozoic Brachiopods of the Moose River Synclinorium, Maine}

By ARTHUR J. BOUCOT

GEOLOGICAL S UR VEY PROFESSIONAL PAPER 784

Descriptions are provided for large Early Devonian and Late Silurian brachiopod faunas of northwestern Maine, together with small Early Silurian and Middle Ordovician faunas

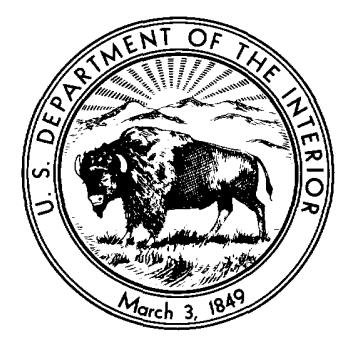




\section{UNITED STATES DEPARTMENT OF THE INTERIOR ROGERS C. B. MORTON, Secretary}

\section{GEOLOGICAL SURVEY}

V. E. McKelvey, Director

Library of Congress catalog-card No. 73-600004 


\section{CONTENTS}

Abstract

Introduction

Age of the faunas

Provinciality

Systematic paleontology

Superfamily Orthacea

Genus Orthambonites Pander, 1830 ......-

Genus Dolerorthis Schuchert and Cooper, 1931 -..-.-.-.-.--

Genus Ptychopleurella Schuchert and Cooper, 1931 -_-

Genus Valcourea Raymond, 1911

Superfamily Dalmanellacea -.............-.

Genus Resserella Bancroft, 1928

Genus Isorthis Kozlowski, 1929

Genus Levenea Schuchert and Cooper, 1931 -

Genus Dicaelosia King, 1850

Genus Discomyorthis Johnson, 1970

Genus Dalejina Havlicek, 1953

Genus Platyorthis Schuchert and Cooper, 1931 -..---_--_-_-

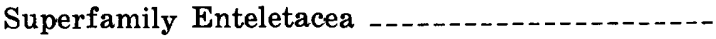

Genus Salopina Boucot, 1960

Superfamily Pentameracea Genus Gypidula Hall, 1867 .......

Genus Sieberella Oehlert, 1887 ......-.--

Genus Pentamerus Sowerby, 1812 .....-.--

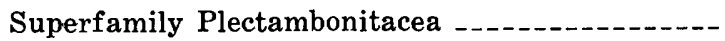

Genus Sowerbyites Teichert, 1937 .........

Superfamily Strophomenacea

Genus Leptaena Dalman, 1828

Genus Stropheodonta Hall, 1852

Genus Leptostrophia Hall, 1892 .........-

Genus Protoleptostrophia Caster, 1939 -.----

Genus Strophonella Hall, 1879 -.--_-_-_--

Superfamily Davidsoniacea _....................

Genus Schuchertella Girty, 1904 -..-.-.--

Genus Hipparionyx Vanuxem, 1842 ......--

Genus Leptaenisca Beecher, 1890 .

Superfamily Chonetacea

Genus Cyrtoniscus Boucot and Harper, 1968.

Genus Eccentricosta Berdan, 1963 ........-

Genus Dawsonelloides Boucot and Harper, 1968

Genus Eodevonaria Breger, 1906 ...-...-.-.

Genus Chonostrophiella Boucot and Amsden, 1964

Superfamily Rhynchonellacea

Genus Cupularostrum Sartenaer, 1961
Page
1

Systematic paleontology-Continued

Genus Ancillotoechia Havlicek, 1959 ..-.-.--

Genus Sphaerirhynchia Cooper and MuirWood, 1951

Genus Sulcatina Schmidt, 1964

Genus Costellirostra Cooper, 1942 -...-.--

Genus Eatonia Hall, 1857 .........-.

Genus Machaeraria Cooper, 1955 .......-.-

Superfamily Atrypacea -..--

Genus Atrypa Dalman, 1828

Genus Lissatrypa Twenhofel, 1914 ......--

Genus Nanospira Amsden, 1951 -..-.-.--

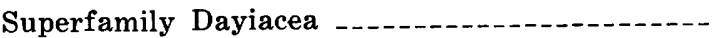

Genus Leptoceolia Hall, 1859

Genus Coelospira Hall, 1863 _._._._. 38

Superfamily Delthyridacea _-_._- 39

Genus Hedeina, Boucot, 1957 _. 39

Genus Delthyris Dalman, 1828 ...-_-_-- $\quad 39$

Genus Howellella Kozlowski, 1946 _..--_--- 39

Genus Acrospirifer Helmbrecht and Wedekind, 1923

Genus Antispirifer Williams and Breger, 1916 -

Genus Costellispirifer Boucot, n. gen. -...-.-

Genus Mucrospirifer Grabau, 1931 -..--.--

Genus Costispirifer Cooper, 1942 -..---.---

Genus Kozlowskiellina Boucot, 1958 ..------

Genus Metaplasia Hall and Clarke, 1893 ...-

Genus Plicoplasia Boucot, 1959

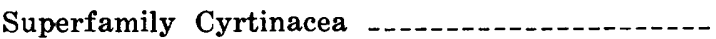

Genus Cyrtina Davidson, 1858 ........-.

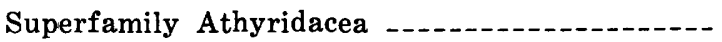

Genus Merista Suess, 1851 -...........-

Genus Meristella Hall, 1860 .......--_-

Genus Charionoides Boucot, Johnson, and Staton, 1964

Genus Nucleospira Hall, 1859 -..-.-.--_--

Genus Protathyris Kozlowski, 1929 ........

Superfamily Terebratulacea

Genus Nanothyris Cloud, 1942 -...-.--_-_-

Genus Rensselaeria Hall, 1859 -..-..-.--_--

Genus Beachia Hall and Clarke, 1893 ...-.-

Genus Cloudothyris Boucot and Johnson, 1968

Genus Amphigenia Hall, 1867

Genus Globithyris Cloud, 1942

Genus Mutationella Kozlowski, 1929 -..--_-

References cited

Index
Page

30

31

33

34

34

35

36

36

37

37

38

38

8

9

39 


\title{
ILLUSTRATIONS
}

\author{
[Plates follow index]
}

Plate 1. Orthostrophia, Schizoramma, Orthambonites?, and Dolerorthis.

2. Dolerorthis, Dolerorthis?, Ptychopleurella, Valcourea, Resserella, and Isorthis.

3. Isorthis, Levenea, unidentified orthoid, Dicaelosia, and Discomyorthis.

4. Discomyorthis, Dalejina, and Platyorthis.

5. Salopina and Gypidula.

6. Gypidula, Sieberella, Pentamerus?, Sowerbyites?, Leptaena, and Stropheodonta.

7. Leptostrophia, Leptostrophia?, and Protoleptostrophia.

8. Protoleptostrophia and Strophonella.

9. "Schuchertella," Hipparionyx, Leptaenisca, and Cyrtoniscus.

10. Eccentricosta and Dawsonelloides.

11. Dawsonelloides, Eodevonaria, and Chonostrophiella.

12. Chonostrophiella, Cupularostrum, Cupularostrum?, Ancillotoechia, "Ancillotoechia," and Sphaerirhynchia.

13. Sphaerirhynchia, Sphaerirhynchia?, and Sulcatina.

14. Costellirostra, Eatonia, Machaeraria, and Atrypa.

15. Atrypa, Lissatrypa, Nanospira?, Leptocoelia, Coelospira, and Hedeina.

16. Delthyris, Howellella?, "Howellella," and Acrospirifer.

17. Acrospirifer.

18. Acrospirifer, Antispirifer, Costellispirifer, "Mucrospirifer," and Costispirifer.

19. Megakozlowskiella, Metaplasia, Plicoplasia, and Cyrtina?.

20. Merista, Meristella, Charionoides, Nucleospira, and Protathyris.

21. Nanothyris, Rensselaeria, and Beachia.

22. Beachia, Cloudothyris, and Amphigenia.

23. Globithyris and Mutationella.

Figures 1-10. Scattergrams for measurements of :
1. Dolerorthis hobbstownensis
2. Ptychopleurella sp
3. Valcourea sp
4. Discomyorthis musculosa solaris
5. Platyorthis planoconvexa
6. Salopina hitchcocki
7. Cyrtoniscus nectus
8. Dawsonelloides canadensis
9. Eodevonaria arcuata
10. Chonostrophiella complanata

11. Serial sections of Ancillotoechia haraganensis from the Haragan Shale of Oklahoma

12. Serial sections of Diabolirhynchia acinus from the Waldron Shale of Indiana

13. Serial sections of "Rhynchonella" bidentata from Silurian rocks near Klinteham, Gotland, Sweden -.

14. Serial sections of "Ancillotoechia" cf. "A." altisulcata

15-19. Scattergrams for measurements of :

15. "Howellella" tomheganensis

16. Acrospirifer murchisoni

17. Acrospirifer atlanticus

18. Antispirifer harroldi

19. Costellispirifer perimele

20. Serial sections of Protathyris sp

21-25. Scattergrams for measurements of :

21. Nanothyris hodgei

22. Amphigenia parva

23. Globithyris callida

24. Globithyris diania

25. Mutationella parlinensis

\section{TABLE}

TABLE 1. Rib branching pattern for brachial valves of Dolerorthis hobbstownensis Boucot, n. sp 


\title{
EARLY PALEOZOIC BRACHIOPODS
}

\section{OF THE MOOSE RIVER SYNCLINORIUM, MAINE}

\author{
By Arthur J. Boucot
}

\section{ABSTRACT}

Brachiopods of the Moose River synclinorium of Maine are described from beds of Middle Ordovician, Early Silurian, Late Silurian, and Early Devonian age, with emphasis on the Early Devonian brachiopods because of their relative abundance and because of their distribution in several zones and several marine communities.

New genus Costellispirifer, a multiribbed delthyrid, is defined. New species are Dolerorthis hobbstowensis, Sieberella beckensis, Cupularostrum macrocosta, Machaeraria mainensis, "Howellella" tomheganensis, and Nanothyris hodgei.

\section{INTRODUCTION}

The stratigraphic and structural geology of the Moose River synclinorium has been dealt with earlier by Boucot $(1961,1969)$. Oliver (1960) described the Devonian corals and Stumm (1962) the Silurian corals; Boucot and Yochelson (1966) described the gastropods; and Whittington and Campbell (1967) described some of the Silurian trilobites. Earlier work on the faunas, chiefly brachiopods, includes the studies of Clarke $(1907,1909)$, Schuchert (in Pirsson and Schuchert, 1914), Williams and Breger (1916, in their report on the Chapman Sandstone fauna), and Goldring (1933). Miscellaneous reports by Boucot and others have dealt with particular parts of the brachiopod fauna in connection with various biologic studies: (Boucot, 1959a, deals with species of Metaplasia and Plicoplasia; Boucot and others, 1963, deal with species of Mutationella; Boucot and Amsden, 1964, deal with species of Chonostrophiella; Boucot and Johnson, 1967a, deal with occurrences of Coelospira; and Boucot and Harper, 1968, deal with occurrences of Dawsonelloides, Cyrtoniscus, and Eodevonaria). Walmsley, Boucot, and Harper (1969) deal with Salopina from the Moose River synclinorium.

The original purpose of the paleontologic and geologic work in the Moose River synclinorium was to determine if the undifferentiated Early Devonian fauna as described by Clarke $(1907,1909)$ and Williams and Breger (1916) contained more than one horizon. Based on his own thesis studies (Cloud, 1942) and an extensive field trip in the area in 1943, Preston E. Cloud, Jr. had suspected that more than one horizon was present and suggested the problem to Boucot in 1948 as a promising subject for a dissertation. The purpose of this report is to document the brachiopod fauna. Extensive work on Appalachian province Early Devonian brachiopod faunas since the completion of the Moose River studies in early 1956 has made possible effective comparison of them with similar faunas occurring elsewhere in the eastern half of North America.

The locality numbers used in this report are from the U.S. Geological Survey's locality registers. Those with the suffix "SD" are from the Silurian-Devonian catalog, those with "CO" from the Cambrian-Ordovician catalog. Details of USGS locs. 2690-SD to 4017-SD are given in Boucot (1969, appendix 1, p. 105-117) and of USGS locs. 4841-SD, 4843-SD, 5583-SD, 5586-SD, 5587-SD, and 5995-SD are given in Albee and Boudette (1972). U.S. National Museum brachiopod catalog numbers are assigned to all the illustrated, figured, and measured specimens.

Boucot and Heath (Boucot, 1969) summarize the geology of the Moose River and Roach River synclinoria, including the structure, stratigraphy, fossil localities, and animal communities. Plate 30 of that report is a generalized geologic map on which the fossil localities are shown. Stratigraphic nomenclature corresponds with that used in the descriptive part of this report.

\section{AGE OF THE FAUNAS}

Early Paleozoic faunas of Middle Ordovician, Early Siiurian, Late Silurian, and Early Devonian age are associated within the Moose River synclinorium. The Middle Ordovician fauna, which includes the brachiopods Orthambonites? sp., Valcourea sp., and Sowerbyites? sp., was previously concluded to be of early to middle Middle Ordovician age as evidenced by the brachiopods.

Early Silurian fossils are not known in the Moose River synclinorium proper, but have been recorded at Limestone Hill in the Stratton quadrangle, which lies on the southeastern side of the synclinorium (Boucot, 1969). On Limestone Hill the occurrence of Pentamerus? sp., Dicaelosia sp., and a species of Amphistrophia similar to A. funiculata suggests a late late Llandovery or possibly very early Wenlock age, from the occurrence of Dicaelosia (late Llandovery-Wenlock type) as well as Amphistrophia 
similar to A. funiculata. The occurrence of Atrypa "reticularis," Howellella, and Eospirifer precludes the possibility of these being of pre-late Llandovery age, as these genera are unknown elsewhere in the world earlier than the late Llandovery.

The Late Silurian faunas are from four sources: Lobster Lake Formation, USGS loc. 3488-SD of the Hardwood Mountain Formation, the remainder of the Hardwood Mountain Formation, and lower conglomerate member of the Hobbstown Formation.

Brachiopods are very rare in the Lobster Lake Formation and were not studied in connection with this report. They include uncollected, poorly preserved specimens of Kirkidium cf. K. knighti from the southwest shore of Lobster Lake, and a Gypidulx similar to the one present in the Hardwood Mountain Formation from the northeast shore (USNM loc. 12113). Stumm (1962, p. 2, 3, 4, 6) and Oliver (1962, p. 11) both consider that the corals of the Lobster Lake Formation are similar to those of the Ludlow and Pridoli age Hardwood Mountain and Mont Wissick Formations. The evidence from both the brachiopods and corals is consistent with a Ludlow age, but a Pridoli age cannot be ruled out, at least in part. This conclusion also applies for at least parts of both the Hardwood Mountain and Mont Wissick Formations. In view of the probable Pridoli age of part of the Hardwood Mountain, a Pridoli age, at least in part, for any "Ludlow" age unit in northern Maine must be considered likely, unless compelling evidence to the contrary is available.

USGS loc. 3488-SD has been assigned to the Hardwood Mountain Formation, which represents a single exposure of calcareous siltstone in an area adjacent to extensive exposures of a lithologically similar unit. However, the fauna of the locality is completely different from that found elsewhere in the Hardwood Mountain. Inspection of table 8 in Boucot (1969) shows that among the 13 brachiopod taxa recognized at this locality only three have been recognized elsewhere in the formation, and these three are the ubiquitous forms, Atrypa "reticularis," Lissatrypa, and Coelospira. The locality has a lower age limit of late Wenlock, as shown by the presence among the brachiopods of Coelospira and Sulcatina. The ostracodes and bryozoans (fenestellids are abundant) are relatively undiagnostic or are new. Whittington and Campbell (1967) conclude that the trilobite fauna from USGS loc. 3488-SD may be of late Wenlock or early Ludlow age. Structurally the locality is inferred to be near the base of the Hardwood Mountain Formation. Summing up all of these data, the author assigns at this time an inferred late Wenlock or Ludlow age for the locality.
The Hardwood Mountain Formation as presently mapped (1969) consists of three discontinuous areas; The Spencer Mountain outlier and adjacent southwest prong of the Moose River synclinorium, the area to the north of Little Big Wood Pond, and a few exposures on the eastern flank of Sally Mountain. The exposures in both the Sally Mountain and Little Big Wood Pond areas have yielded Eccentricosta, a genus restricted in the central Appalachians to beds of Pridoli age. Unfortunately Eccentricosta is virually unknown from an evolutionary point of view and is difficult to use in determining the age of the containing beds in the northern Appalachians. The occurrence (Klapper in Boucot, 1969) of very latest Ludlow through Pridoli age conodonts at one locality on the north shore of Little Big Wood Pond makes it likely that the northern exposures of the formation which contain Eccentricosta are indeed of Pridoli age. Corals from the Little Big Wood Pond area were concluded by both Stumm (1962) and Oliver (1962), to be of "Ludlow" age, but this age determination is an earlier one made when the distinction between strata of Ludlow and Pridoli age was not yet practicable within the northern Appalachians. J. M. Berdan, in Boucot (1969) considers that ostracodes from the Hardwood Mountain Formation of the Little Big Wood Pond area can be best correlated with the Pridoli age Tonoloway Limestone. Considering all this evidence and the fact that the conodont collection was made within about ten feet of the unit's base, the author concludes that the Hardwood Mountain Formation of the Sally Mountain and Little Big Wood Pond area is largely, if not entirely, of Pridoli age.

The Hardwood Mountain Formation of the Spencer Mountain outlier and of the adjacent synclinorium to the southeast does not contain any brachiopods of zonal value, but the ostracodes (see Berdan in Boucot, 1969) do indicate a correlation with the Pridoli age Tonoloway Limestone. The overlying fauna recovered from the basal few inches of the Hobbstown Formation is certainly Silurian, as shown by the presence in the Appalachians of such brachiopod genera as Dolerorthis, Ptychopleurella, Resserella, and Delthyris (Delthyris). The ostracode Limbinaria? cf. L.? muricata (Berdan in Boucot, 1969) suggests a Tonoloway, that is, Pridoli correlation. The available evidence suggests that the Hardwood Mountain Formation of the Spencer Mountain outlier and adjacent synclinorium is at least partly, if not almost entirely of Pridoli age, but a Ludlow or even a late Wenlock age for a part of the formation seems reasonable at this time.

The fauna obtained from the basal few inches of 
the Hobbstown Formation's lower conglomerate member is considered to be of probable Pridoli age. Other considerations (Boucot, 1969) make it likely that this fauna from the basal few inches was reworked from Silurian sediment and redeposited in an essentially Lower Devonian rock unit.

The Lower Devonian faunas of the Moose River synclinorium may be divided into three age units: a lower unit of middle or late Helderberg age (see Boucot and Johnson, 1967b), a middle unit of Oriskany age, and an upper unit of Schoharie age. Strata of Esopus age that contain recognizable marine fossils have not been found in this region.

Strata of middle or late Helderberg age containing datable fossils include the basal Seboomook Formation near Beck Pond, the Bear Pond Limestone Member of the Seboomook Formation, the Beck Pond Limestone, and the Parker Bog Formation. Boucot and Johnson (1967b) have summarized the arguments for the middle or late Helderberg age of the Beck Pond Limestone and the Bear Pond Limestone Member of the Seboomook. The scanty fauna from the Parker Bog Formation is consistent with a middle or late Helderberg age but cannot be used to prove it. Similarly scanty are the basal Seboomook fossils of Helderberg age in the Beck Pond area (these shells occur in a stratigraphic position below the Bear Pond Limestone Member), although the occurrence of Spinoplasia would appear to rule out an early Helderberg age.

Strata of Oriskany age within the synclinorium include the Tarratine Formation and most of the Seboomook Formation. The presence of Rensselaeria, Hipparionyx, Beachia, Costispirifer, and Dawsonelloides is consistent with an Oriskany age for the Tarratine Formation. The intertonguing relations of the Seboomook and the Tarratine (Boucot, 1969) and the similarity of the fauna indicate that the greater part of the Seboomook is of Oriskany age in this region.

The Schoharie age beds in the Moose River synclinorium include the Tomhegan Formation and the Kineo Rhyolite. Only the Tomhegan has yielded diagnostic fossils. The presence of small Amphigenia, Eodevonaria arcuata, Acrospirifer atlanticus, and Charionoides doris indicate that the Tomhegan fauna is of Schoharie age.

\section{PROVINCIALITY}

The Middle Ordovician Kennebec Formation has yielded a very small fauna (Boucot, 1969), but all the elements present suggest an association with Central and Southern Appalachian rather than with northern European forms. Other shelly faunas from northern Maine of Ordovician age (Neuman, 1968) differ sharply from that of the Kennebec Formation. This evidence indicates that Maine was a boundary region during the Ordovician and included European-type faunas in both Aroostook and Penobscot Counties to the northeast and Appalachian types in Somerset County to the southwest. The evidence obtained by Lespérance (1968) for the Late Ordovician trilobites of Gaspé is similar in that it indicates that Gaspé lay near a boundary between Appalachianand European-type regions for at least part of the Ordovician.

The Silurian (see Boucot and others, 1969) was a time of great cosmopolitanism for the brachiopod faunas. Toward the end of the Silurian this situation began to deteriorate into a more provincial condition. In Somerset County, the presence of the endemic Appalachian chonetid genus Eccentricosta is consistent with this conclusion, as the containing beds are probably of Pridoli, that is, latest Silurian age. The ostracode fauna of the central Appalachians differs largely from that of northern Europe, and the occurrence of central Appalachian-type ostracodes in the probably Pridoli-age strata of Somerset County is in great contrast to the Baltic-type fauna of coastal Maine (Berdan, p. 39, 40 and Martinsson, p. 4143 , in Berry and Boucot, 1970). These data indicate that during Pridoli time there was a boundary between an old World province-type fauna in coastal Maine and adjacent New Brunswick, and the Appalachian province precursors in northern Maine, adjacent Quebec and through Gaspé. It is emphasized, however, that during Pridoli time most of the brachiopods of northern Maine, adjacent Quebec, and Gaspé belonged to relatively cosmopolitan genera. The scanty pre-Pridoli age Silurian fauna in this region from Limestone Hill is concluded to be of late late Llandovery age and is a typical Silurian cosmopolitan shelly fauna.

The Helderberg faunas of the Moose River synclinorium contain a variety of brachiopods, all of which have Appalachian province affinities or belong to widespread taxa. The same situation holds for faunas of Oriskany and Schoharie age. The only anomaly is the abundance of Mutationella in the Oriskany age faunas, because this genus, which also occurs in the Rhenish community of the Old World province, can be interpreted to be an old World genus, but more probably it is a member of a relatively near-shore community (the "Mutationella community" of Boucot and Johnson, 1967b) which also occurs in the old World province. The same problem is posed by the abundant representatives of Globithyris which occur in the widespread globithy- 
rid community of both Oriskany and Schoharie age in the Moose River synclinorium. The earliest representatives in this region of an undoubted Old World province brachiopod fauna occur about fifty miles to the northwest at Saint George, Quebec, where several genera of Old World province affinity occur in the Onondaga (that is, Eifelian) age Famine Limestone. Oliver's (1967) analysis of the coral fauna in eastern North America during the Helderberg through Onondaga interval is similar to the brachiopod analysis presented here.

\section{SYSTEMATIC PALEONTOLOGY}

\author{
PHYLUM BRACHIOPODA \\ Class ARTICULATA \\ Suborder ORTHOIDEA \\ Superfamily ORTHACEA \\ Family ORTHIDAE \\ Subfamily ORTHOSTROPHIINAE \\ Genus ORTHOSTROPHIA Hall, 1883
}

As pointed out by Williams (1951, p. 91), Orthostrophia is predominantly orthid in its general form. Williams emphasized the orthid nature of the cardinalia associated with plectorthid-type pallial marks. Williams (1951, p. 90), after finding a dolerorthid (his Schizoramma cf. subplicata) with plectorthidtype pallial marks, concluded that pallial marks were of less value in making family assignments than cardinalia. However, Williams, in reassigning Orthostrophia to the Hesperorthinae, ignored the external and internal differences between Orthostrophia and the genera of the Hesperorthinae which constitute valid grounds for leaving the former in a distinct subfamily, albeit of the Orthidae rather than the Plectorthidae. More recently Williams (1965) classified Orthostrophia with the Orthinae.

Probably the most prominent feature of Orthostrophia vis-a-vis the hesperorthinids is the presence in the former of a reversal of fold and sulcus from the presence in the umbonal region of a pedicle valve fold to a prominent sulcus anteriorly and corresponding features in the brachial valve. Orthostrophia has accessory ridges parallelling the linear cardinal process in a manner reminiscent of true Schizoramma (pl. 1, figs. 13, 14).

Orthostrophia cf. 0. brownsportensis Amsden, 1949

Plate 1, figures 1-5

Exterior.-Shells transverse in outline. Straight hinge line position of maximum width. Lateral margins relatively straight, normal to hinge line posteriorly, round evenly into anterior margin. Anterior margin evenly rounded, crenulate, unisulcate. Pedicle valve bears low fold in umbonal region which becomes transformed into prominent sulcus anteri- orly; brachial valve bears low sulcus in umbonal region which becomes transformed into fold anteriorly. Radial costellae increase by both bifurcation and implantation. Concentric filae, growth lines. Pedicle valve interarea strongly apsacline, about twice length anacline brachial valve interarea. Both valves evenly convex. Pedicle valve about twice as deep as brachial valve.

Pedicle valve interior.-Dental lamellae very short, almost completely obsolescent. Hinge teeth stout. Muscle field very short, divided into median sector bounded laterally by two lateral sectors, all concentrically striated. Radial ornamentation impress prominent except in delthyrial cavity. At bottom of delthyrial cavity is low subcircular ridge which may have bounded adjustor attachment area.

Brachial valve interior. - Cardinalia consist of stubby brachiophores bounding edge of notothyrial cavity, linear cardinal process, pair of thin ridges paralleling closely cardinal process margins. Low myophragm extends anteriorly from cardinal process margins. Low myophragm extends anteriorly from cardinal process; bisects very deeply impressed adductor field. Adductor field quadripartite.

Comparison.-O. cf. O. brownsportensis is more finely costellate than $O$. strophomenoides and bears a narrower fold and sulcus anteriorly.

Occurrence.--USGS loc. 4843-SD, Attean quadrangle, Somerset County, Maine.

Stratigraphic location.-Hardwood Mountain Formation (Upper Silurian).

Figured specimens._USNM 160109-160111.

Orthostrophia cf. 0. strophomenoides (Hall, 1857)

Plate 1, figures 6-12

Exterior.-Shell gently biconvex, with pedicle valve possessing greater convexity. Outline subcircular, greatest width near midlength. Brachial valve sulcate posteriorly, bears fold anteriorly; pedicle valve lacks sulcus posteriorly, develops one anteriorly in large shells. Hinge line straight. Pedicle valve interarea about three times as long as that of brachial valve. Pedicle valve interarea apsacline, that of brachial valve anacline. Both valves multicostellate; costellae appear to originate largely by bifurcation. Anterior commissure uniplicate, crenulate.

Pedicle valve interior.-Interior prepared impression does not show interior details very satisfactorily. Short dental lamellae present; laterally bound muscle attachment area. Latter restricted to delthyrial cavity, appears tripartite, with median portion slightly more depressed than two lateral portions. Medial impression expands anteriorly, probably adductors attachment site. Muscle field 
crossed by striations subparallel to hinge line. No trace of pallial marks found on specimen studied.

External costellae impression marked, particularly in antero-median part of shell; this feature may be partly associated with deformation of the specimen.

Brachial valve interior.-Anterior portion dental sockets formed by stubby brachiophores, posterior portion by interarea edge. Linear cardinal process grades anteriorly into short myophragm which has triangular cross section. Subcircular adductor attachment area divided medially by myophragm, bounded laterally by low ridges, divided transversely by low ridge normal to myophragm. Pallial markings not identified on available material. Impression of costellae on interior marked in anterior and lateral portions of shell. Valves large, several are 35 to $40 \mathrm{~mm}$ wide.

Comparison.-Material from the Beck Pond Limestone most closely resembles $O$. strophomenoides from the New Scotland Formation of eastern New York, but poor preservation and inadequate number of specimens preclude positive specific identification.

Occurrence.-USGS loc. 3499-SD, Spencer Lake quadrangle, Somerset County, Maine.

Stratigraphic location.-Beck Pond Limestone (Lower Devonian).

Distribution.-Species is known only from eastern North America and Oklahoma. B.

Figured specimens.-USNM 125785B, 125786A-

Unfigured specimens._USNM 125787A, 125788B, $125789 \mathrm{C}, 125790 \mathrm{D}, 125791 \mathrm{E}, 125792 \mathrm{~A}$.

\section{Subfamily ORTHINAE \\ Genus ORTHAMBONITES Pander, 1830 \\ Orthambonites? sp. \\ Plate 1, figures 15-17}

Exterior.-Unequally biconvex shell, brachial valve gently convex, pedicle valve subpyramidal. Greatest width at straight hinge line. Pedicle valve interarea steeply apsacline, brachial valve interarea appears anacline. Pedicle valve interarea much longer than that of brachial valve. Lateral margins gently rounded. Anterior margin rectimarginate, crenulate. Radiating costae; no secondary costae evident on specimen studied.

Comparison.-The single impression of the exterior available is questionably assigned to Orthambonites on the basis of convexity of the brachial valve which is unlike the flat brachial valve of Hesperorthis. Pedicle valve interarea is too poorly preserved for the determination of the presence or absence of a pseudodeltidium.
Occurrence.-USGS loc. 4317-CO, Brassua Lake quadrangle, Somerset County, Maine.

Stratigraphic location.-Kennebec Formation (middle Middle Ordovician).

Figured specimen.-USNM 125753.

\author{
Family HESPERORTHIDAE \\ Subfamily DOLERORTHINAE \\ Genus DOLERORTHIS Schuchert and Cooper, 1931 \\ Dolerorthis hobbstownensis Boucot, n. sp. \\ Plate 1, figures 18-26
}

Exterior.-Shells unequally biconvex, pedicle valve subconical, brachial valve gently convex; elliptical to subcircular in outline. Brachial valve sulcus more prominent in early than in late growth stages. Hinge line straight, lateral margins rounded, greatest width occurring about midlength. Pedicle valve interarea steeply apsacline, in crushed specimens it appears gently apsacline; brachial valve interarea gently anacline. Pedicle valve interarea about three times as long as that of brachial valve. Sides of delthyrium subparallel but in crushed specimens they commonly include angle of about $45^{\circ}$. Number of primary plications (table 1) originating near beak usually six or seven each side of midline. Two secondary plications occur in brachial valve sulcus; similarly on either side of pedicle valve medial primary plication. Secondary plications bifurcate a few millimeters anterior to umbo. Secondary plications associated with other primary plications originate slightly anterior to those in sulcus or associated with median primary of pedicle valve. Those originating on brachial valve do so on medial side of primary plication, whereas reverse true of pedicle valve. Tertiary plications uncommon except in third primary which gives rise to tertiary plication in about 50 percent of specimens examined. Interspaces crossed by prominent filae. Anterior commissure of small shells sulcate, but in larger specimens becomes almost rectimarginate, crenulate.

Pedicle valve interior.-Short dental lamellae diverge laterally from anterior face of palintrope and bound muscle attachment area. Hinge teeth stubby and occur medially on hinge line; they are supported in part by dental lamellae. Muscle field located entirely within delthyrial cavity, lies on pad of secondary material which floors this part of valve and raises it slightly above level of rest of valve. Anterior margin crenulated, both anterior and lateral portions of shell bear impression of external coarse costellae.

Brachial valve interior.-Cardinalia consist of linear, blade-like cardinal process resting on notothyrial platform bounded by short, stout brachiophores whose posterior faces are in same plane as interarea. Dental sockets floored by fulcral plates, 
TABLE 1.-Rib branching pattern for brachial valves of Dolerorthis hobbstownensis Boucot, $n$. $s p$

\begin{tabular}{|c|c|c|c|c|c|c|c|c|c|c|c|c|c|c|c|c|c|c|c|c|c|c|c|c|c|c|}
\hline \multicolumn{27}{|c|}{$\begin{array}{l}\text { [From collection of specimens numbered } 1-55 \text {, from base of Hobbstown Formation, USGS loc. } 3479-\text { SD, Spencer Lake quadrangle, Somerset County, } \\
\text { Maine } 1,2,3 . \ldots \text {, primary costella; } 12 \text { median secondary costella; } 13 \text { tertiary to median secondary costella; } 23,33 \text {, lateral secondary costella to } \\
\text { respective primary. L and } R \text { refer to left and right side of valve; } 1 \text { and } 2 \text { refer to one or more costellae of that order in that position] }\end{array}$} \\
\hline $\begin{array}{c}\text { Speci- } \\
\text { men }\end{array}$ & $L^{1}$ & & \multicolumn{2}{|c|}{$L^{12} R$} & $\mathrm{~L}^{13} \mathrm{R}$ & \multicolumn{2}{|c|}{$L^{2} R$} & \multicolumn{2}{|c|}{$L^{23} R$} & \multicolumn{2}{|c|}{$\mathrm{L}^{3}{ }_{\mathrm{R}}$} & \multicolumn{2}{|c|}{$L^{33}{ }_{R}$} & \multicolumn{2}{|c|}{4} & \multicolumn{2}{|c|}{43} & \multicolumn{2}{|c|}{${ }^{5}$} & \multicolumn{2}{|c|}{$L^{5_{3}} R$} & \multicolumn{2}{|c|}{$\mathrm{L}^{6} \mathrm{R}$} & \multicolumn{2}{|c|}{$L^{7} R$} & $L^{8} R$ \\
\hline 1 & 1 & 1 & 1 & 1 & & 1 & 1 & 1 & 1 & 1 & 1 & & 1 & 1 & 1 & 1 & & 1 & 1 & & & 1 & 1 & 1 & & \\
\hline$\overline{5}$ & 1 & 1 & 1 & 1 & & 1 & 1 & 1 & 1 & 1 & & $\overline{2}$ & 1 & $\tilde{1}$ & 1 & $\ldots$ & & 1 & & -1 & & 1 & 1 & -- & -- & -- \\
\hline 7 & $\overline{1}$ & $\overrightarrow{1}$ & $\overline{1}$ & $\overline{1}$ & -- & 1 & 1 & 2 & 1 & 1 & 1 & $\overline{2}$ & 1 & $\overline{1}$ & & 1 & & $\overline{1}$ & & -- & & -- & -- & & & \\
\hline 9 & 1 & $\hat{1}$ & 1 & $\overline{1}$ & 1 & 1 & 1 & 1 & 1 & 1 & 1 & 2 & 2 & 1 & 1 & $\ldots$ & 1 & 1 & 1 & $\ldots$ & - & -- & 1 & -- & 1 & - \\
\hline 10 & 1 & $\overrightarrow{1}$ & 1 & 1 & --- & 1 & 1 & 1 & 1 & $\ldots$ & 1 & $\ldots$ & 1 & -- & & - & -- & & & & & & & & & \\
\hline 1 & 1 & 1 & 1 & 1 & --1 & 1 & 1 & 1 & .- & 1 & $\hat{1}$ & 1 & & 1 & 1 & - & - & 1 & 1 & 1 & & - & $\overrightarrow{1}$ & - & & \\
\hline 2 & 1 & 1 & $\overline{1}$ & 1 & -- - & 1 & 1 & -- & -- & 1 & 1 & 1 & 2 & 1 & 1 & -. & -- & 1 & 1 & $\ldots$ & & 1 & $\overline{1}$ & - & 1 & --1 \\
\hline 4 & 1 & 1 & 1 & 1 & -- - & -- & 1 & -- & 1 & -- & 1 & - & 2 & -- & 1 & -- & -- & $\ldots$ & 1 & -- & -- & -- & 1 & $\ldots$ & -- & $\ldots$ \\
\hline 5 & 1 & 1 & $\overline{1}$ & $\overline{1}$ & - & 1 & 1 & 1 & 2 & 1 & & 2 & 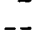 & 1 & -- & - & & 1 & & -- &.- & -- & - & -- & -- & \\
\hline 7 & 1 & 1 & 1 & 1 & -- & 1 & 1 & 1 & 1 & 1 & 1 & -. & 1 & $\overline{1}$ & & 1 & & $\ldots$ & 1 & -- & & -- & & $\ldots$ & & \\
\hline 8 & 1 & 1 & 1 & 1 & -- & 1 & 1 & 1 & 1 & $\overline{1}$ & 1 & 1 & 1 & 1 & 1 & 1 & 1 & 1 & 1 & $\ldots$ & & 1 & 1 & - & - & $-1-1$ \\
\hline 29 & 1 & 1 & $\ldots$ & -- & --- & 1 & 1 & -- & -- & 1 & 1 & $-\overline{-}$ & $-\rightarrow$ & 1 & 1 & $\rightarrow$ & & -- & - & $\ldots$ & & -- & & & & \\
\hline & 1 & 1 & 1 & 1 & --1 & 1 & 1 & 1 & 1 & 1 & 1 & 2 & 2 & 1 & 1 & 1 & 1 & 1 & 1 & $\ldots$ & & 1 & 1 & & & - \\
\hline 1 & 1 & 1 & 1 & 1 & -- & 1 & 1 & 1 & 1 & 1 & 1 & $\overline{2}$ & $\overline{1}$ & 1 & 1 & 1 & & 1 & 1 & - & & 1 & 1 & $\overline{1}$ & -1 & \\
\hline & 1 & $\overline{1}$ & 1 & 1 & --- & 1 & 1 & -- & & 1 & 1 & -- & -- & 1 & 1 & -- & & 1 & 1 & -- & & -- & 1 & -- & & - - - \\
\hline 2 & 1 & 1 & 1 & 1 & -- - & 1 & 1 & 1 & 1 & 1 & 1 & 1 & -- & 1 & 1 & - & 1 & 1 & $=-$ & -- & & 1 & & -- & -- & \\
\hline 7 & 1 & 1 & 1 & 1 & $=-$ & 1 & 1 & 1 & 1 & 1 & 1 & 1 & & 1 & 1 & 1 & $\ldots$ & - & 1 & -- & & & 1 & - & & $\ldots$ \\
\hline 9 & $\overline{1}$ & 1 & $\overrightarrow{1}$ & 1 & -- - & 1 & 1 & $\overline{2}$ & 1 & 1 & 1 & $\overline{2}$ & $\overline{2}$ & 1 & 1 & $\ldots$ & -- & 1 & & -- & & $\overline{1}$ & 1 & -- & - & \\
\hline & 1 & 1 & 1 & 1 & 1 & 1 & 1 & -- & $\hat{1}$ & 1 & 1 & 1 & 2 & 1 & 1 & -- & 1 & 1 & 1 & $\ldots$ & -- & 1 & 1 & - & - & - \\
\hline 1 & 1 & 1 & 1 & 1 & $\ldots-\overline{1}$ & 1 & 1 & $\overline{1}$ & 2 & 1 & 1 & 2 & 2 & 1 & 1 & -- & $\ldots$ & 1 & -- & & & & -- & -- & -- & \\
\hline- & 1 & 1 & 1 & 1 & -- - & $\ldots$ & $\overline{1}$ & -- & 1 & $\ldots$ & 1 & & 1 & - & 1 & -- & & & 1 & -- & & - & 1 & - & - & -- \\
\hline- & $\ldots$ & - & -- & -- & $--1--$ & $\overrightarrow{1}$ & -- & -- & - & $\overline{1}$ & & $\overline{2}$ & & $\overrightarrow{1}$ & & $\overline{2}$ & & 1 & & -- & -- & -- & - & -- & - & $-\ldots$ \\
\hline
\end{tabular}

laterally formed by outer face of brachiophores and by inner face of interarea. Low rounded median septum extends from anterior face of notothyrial platform to about midlength. Adductor impressions poorly impressed, but noticeable posteriorly, fading anteriorly. Anterior margin crenulated, and anterior and lateral portions of shell impressed by external costellae.

Measurements.-Scatter diagrams of length versus width for both pedicle and brachial valves are essentially linear (fig. 1). The plot for pedicle valves exhibits greater degree of dispersion than that for brachial valves. This greater dispersion is probably due to the pedicle valve having been a far more convex valve which upon crushing (most of specimens are crushed) has had its linear dimensions subjected to a greater amount of alteration than the relatively flat brachial valve. The slope of both plots is about $55^{\circ}$ It is unlikely that there is a radical change in slope of the growth curve from small specimens (smaller than available for study) to large specimens because the extrapolated growth line would approximately pass through the origin. A greater degree of dispersion accompanies increase in overall size, but this does not indicate a greater degree of variation but rather about the same percentage variation. Both samples are strongly skewed towards larger sizes which suggests that abstraction of smaller specimens from sample occurred, although it is unclear whether this occurred during transportation or in situ.

Comparison.-D. hobbstownensis is more coarsely cos tellate than the previously described species of

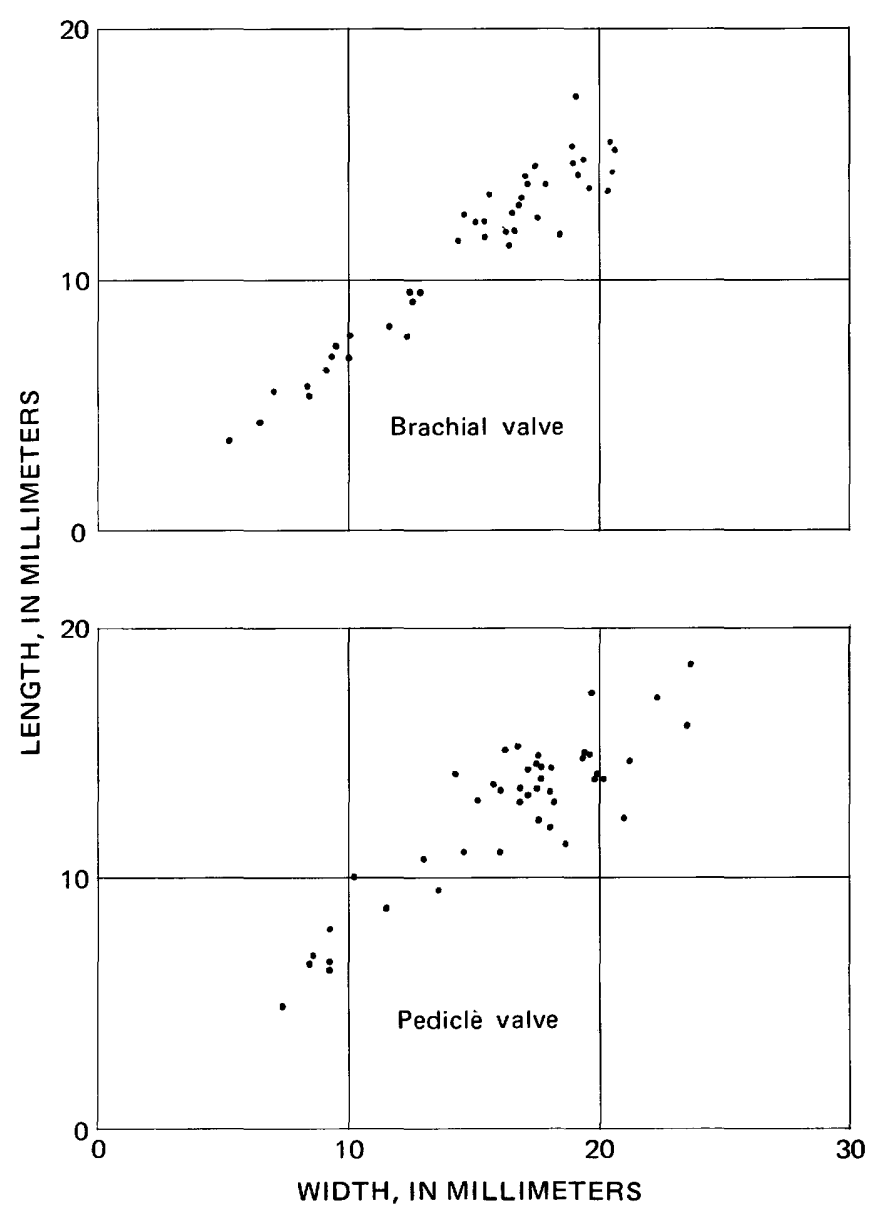

FIGURE 1.-Comparison of length versus width for brachial and pedicle valves of Dolerorthis hobbstownensis from the base of the Hobbstown Formation. Locality 3479-SD, Spencer Lake quadrangle, Somerset County, Maine. 
Doler orthis sensu stricto. The rib-branching pattern of $D$. hobbstownensis is less complicated than that. of the previously described species.

Occurrence.-USGS locs. 2712-SD, 3479-SD, Spencer Lake quadrangle, Somerset County, Maine.

Stratigraphic location.-Base of Hobbstown Formation (Upper Silurian). Possibly Late Silurian shells reworked in basal part of a Devonian unit (Boucot, 1969, p. 39-40).

Figured specimens.-USNM 125796A, B (holotype), 125797B, 125903A.

Measured paratypes.-USNM 125799.

Unmeasured specimens._USNM 126272, 126273.

Dolerorthis cf. D. hami (Amsden, 1951)

Plate 2, figures 1-5

Exterior.-Shell unequally biconvex, pedicle valve subconical, brachial valve gently convex. Brachial valve sulcate. Shell outline subcircular to elliptical. Anterior commissure sulcate, crenulate. Straight hinge line, greatest width near midlength. Pedicle valve interarea steeply apsacline, brachial valve interarea anacline. Costellae which increase by bifurcation. Brachial valve sulcus contains two pairs secondary costellae, one pair tertiary costellae. Fine filar ornamentation concentrically crosses interspaces, absent from crests of costellae.

Pedicle valve interior.-Short dental plates laterally bound low pad secondary material in delthyrial cavity on which are situated impressions of muscle field. Hinge teeth nature not clear on one specimen available for study. External costellae impressions reflected on anterior and lateral portions of interior.

Brachial valve interior.-Cardinalia consist of linear, bladelike cardinal process situated on notothyrial platform lateral to which are located relatively short anteriorly directed brachiophores. Muscle field nature difficult to ascertain on one specimen available but paired adductor impressions near anterior face notothyrial platform are medially divided by low myophragm. External costellae impression reflected on anterior and lateral portions of interior.

Comparison.-The material from Maine is inadequate for definitely determining specific position; most closely resembles $D$. hami.

Occurrence.-USGS loc. 3479-SD, Spencer Lake quadrangle; loc. 5995-SD, Attean quadrangle, Somerset County, Maine.

Stratigraphic location.-Base of Hobbstown Formation and Hardwood Mountain Formation (Upper Silurian).

Distribution.-Central Oklahoma; northern Maine.
Figured specimens.-USNM $125794 \mathrm{~A}-\mathrm{B}$, $125795 \mathrm{~A}-\mathrm{B}, 160112$.

\section{Dolerorthis? sp. \\ Plate 2, figures 6-8}

Exterior.-Gently convex pedicle valve (no brachial valve available) has subcircular outline. Hinge line straight, greatest width at hinge line. Pedicle valve sulcate. Lateral extremities rounded towards anterior. Anterior commissure gently uniplicate, crenulate. Numerous bifurcating costellae crossed by filae restricted to interspaces.

Pedicle valve interior.-Hinge teeth located on medial margin of hinge line, appear short. Dental plates short, laterally bound muscle attachment area. Muscle field located on pad secondary material that raises delthyrial cavity floor slightly above rest of valve. Muscle field nature not elucidated from fragmentary specimen available. External costellae impression leaves imprint on anterior, lateral portions of shell.

Comparison.-The two fragmentary specimens available are insufficient to assign material generically. Relatively fine costellae, nature of pedicle valve muscle field, presence of filae in interspaces between costellae are suggestive of Dolerorthis. Most closely resembles forms like $D$. rustica osiliensis (Schrenk, 1858), unlike pauciplicate forms assigned to genus.

Occurrence.-USGS loc. 3479-SD, Spencer Lake quadrangle, Somerset County, Maine.

Stratigraphic location.-Base of Hobbstown Formation (Upper Silurian).

Figured specimens.-USNM $125800 \mathrm{~B}-\mathrm{C}$.

Unfigured specimens.-USNM 125800A.

Subfamily GLYPTORTHINAE

Genus PTYCHOPLEURELLA Schuchert and Cooper, 1931

Ptychopleurella sp.

Plate 2, figures 9-17

Exterior.-Unequally biconvex, pedicle valve subconical, brachial valve convex. Brachial valve bears deep median sulcus. Hinge line straight, maximum width slightly anterior of midlength. Shell outline transversely elliptical, width about one and one-half times length. Pedicle valve interarea apsacline, brachial valve interarea orthocline. Anterior commissure rectimarginate, crenulate. Delthyrium sides subparallel, apparently unmodified by delthyrial structures. Primary costellae bifurcate anteriorly giving rise to secondary and tertiary costellae. Small specimens (less than a few millimeters long) do not possess secondary or tertiary costellae). Three to four primary plications present either side midline. Coarse, radial ornamentation crossed by fine, concentric lamellae. 
Pedicle valve interior.-Short dental plates laterally bound delthyrial cavity, intersect palintrope anterior face lateral to delthyrial margin. Hinge teeth short, located medial part hinge line. Secondary material pad laid down in delthyrial cavity slightly anteriorly, greatest thickness material anterior simulating spondylium. Pad secondary material narrows medially to diamond-shaped ridge. Median portion muscle field slightly elevated and parallel-sided; covering about one-half total area muscle attachment. Paired, narrow diductor impressions lateral to median scar. Small pedicle callist at posterior part delthyrial cavity. Anterior and lateral margins strongly crenulated.

Brachial valve interior.-Cardinalia consist of rounded cardinal process (narrow, linear cardinal process present in small individuals) rising from notothyrial platform laterally bounded by short, stout brachiophores laterally fused to valve posterior margin. Dental sockets bounded anteromedially by brachiophores, posteriorly by interarea, are relatively narrow. Broad myophragm, rounded in cross section, descends anteriorly from notothyrial platform to point slightly anterior of midlength. Adductor impressions divided medially by low myophragm and laterally by paired, laterally diverging myophragms. Laterally diverging myophragms marked posteriorly but decrease in height anteriorly and serve to divide adductor impressions into two scar pairs. Lateral pair adductor impressions about half length of medial pair, both pairs relatively elongate in outline. Anterior and lateral margins strongly crenulate.

Measurements.-Scatter diagram of length versus width of brachial valves is essentially linear (fig. 2), although the short size interval represented by sample precludes conclusions as to linearity or departure therefrom of growth curve as a whole. Sample appears normally distributed which suggests that small specimens have been abstracted at growth site or that this portion of the original population has undergone transport and sorting. Slope of growth line about $50^{\circ}$ and amount of dispersion not great for this type of orthoid.

Comparison.-Adequate comparative material is not available with which to ascertain specific identity of the Maine material. It is not markedly dissimilar to previously described Ptychopleurella s. s. species; likely that group of species assigned to this genus needs revision.

Occurrence.-USGS loc. 3479-SD, Spencer Lake quadrangle, Somerset County, Maine.

Stratigraphic location.-Base of Hobbstown Formation (Upper Silurian).

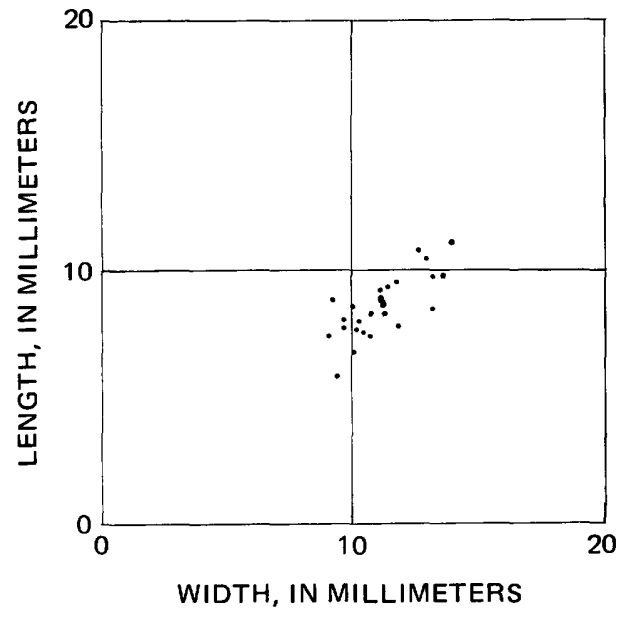

FIGURE 2.-Relationship of length versus width in impressions of interior of brachial valves of Ptychopleurella sp. USGS loc. 3479-SD, Spencer Lake quadrangle, Somerset County, Maine.

Distribution.-Genus known from Europe and North America.

Figured specimens.-USNM 125801A-B, 125802A, 125803B, 125804.

Measured specimens.-USNM 125801-125803.

Unmeasured specimens.-USNM 125805.

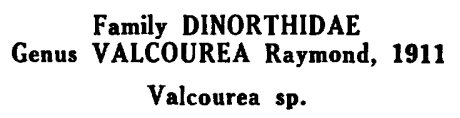

Plate 2, figures 18-22

Exterior.-Pedicle valve concave, brachial valve evenly convex, latter has greater degree of curvature than former. Greatest width at straight hinge line. Pedicle valve interarea steeply apsacline, brachial valve interarea anacline. Pedicle valve interarea about three to four times longer than that of brachial valve. Valve outline subcircular to elliptical, but deformation helps determine outline. A study of relationship between length and width in a number of species of Valcourea and in material from Maine (fig. 3) indicates that degree of variability in material from Maine is far greater than in other shell populations. The much greater variability of Maine specimens should probably not be ascribed to biologic cause but rather to deformation. Relation between length and width changes with size. Width increases at greater rate than length, that is, shells tend to become subcircular with increasing size from originally transverse condition. Delthyrium closed by convex pseudodeltidium and notothyrium closed by convex chilidium. Lateral margins of valves evenly rounded. Brachial valve bears broad sulcus and pedicle valve corresponding low fold. Shells stro- 
phomenoid in appearance. Costellae increase by bifurcation, crossed by fine concentric lines. Anterior commissure faintly uniplicate and crenulate.

Pedicle valve interior.-Short dental plates laterally bound deeply impressed muscle field. Hinge teeth short, rounded, supported by dental lamellae. Muscle field tripartite, consisting of median, narrow adductor impression with subparallel sides, laterally bounded by relatively elongate diductor impressions that extend anteriorly beyond adductor impression area. Anterior part adductor impression slightly elevated above corresponding parts of diductor impressions.

Brachial valve interior.-Cardinalia consist of rounded cardinal process anteriorly joining with rounded median septum and short, stubby brachiophores.

Measurements.-Scatter diagram of length versus width for specimens from Maine shows an abnormally great dispersion for an orthoid brachiopod (fig. 3). To check this seemingly abnormal distribu-

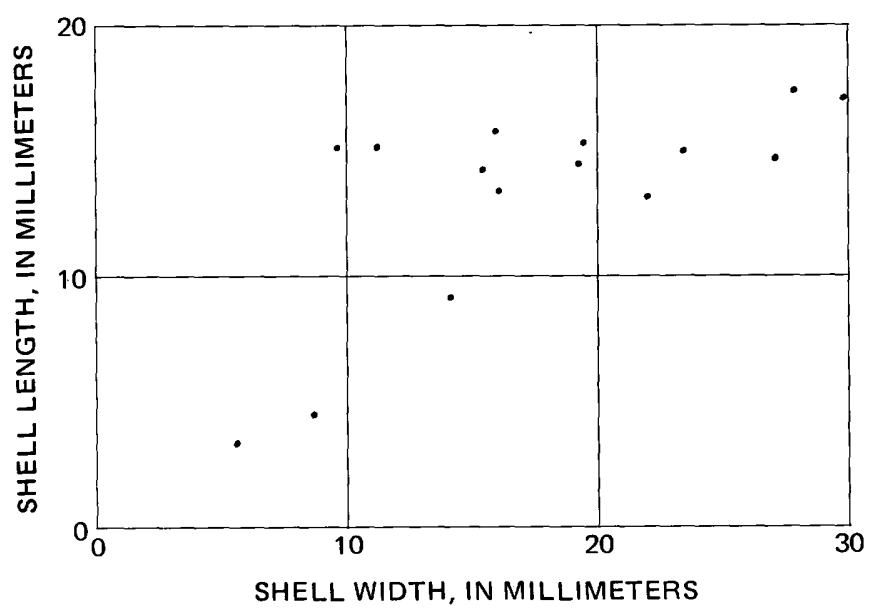

Figure 3.-Relationship of length versus width of shell impressions of Valcourea sp., Kennebec Formation, USGS loc. 4317-CO, Brassua Lake quadrangle, Somerset County, Maine.

tion, five undistorted samples belonging to four species of the genus were measured. The study of five plots obtained from undistorted samples showed conclusively that the sample from Maine had an abnormally high degree of dispersion in terms of biologic variation. Abnormal degree of dispersion is ascribed to distortion of specimens by mechanical means. The growth line slope for specimens from Maine is relatively meaningless because the amount of mechanical deformation undergone by specimens has completely obscured and altered their form. The sample from Maine is normally distributed, but it is not possible to ascribe distribution to either transportation or abstraction of small specimens in situ.

Discussion.-The material from Maine has undergone a great amount of deformation making it impossible to assign specifically because the form of the exterior is the basis used for discriminating between species of the genus (Cooper, 1956).

Occurrence.-USGS loc. 4317-CO, Brassua Lake quadrangle, Somerset County, Maine.

Stratigraphic location.-Kennebec Formation (middle Middle Ordovician).

Distribution.-The genus is restricted to North America and Scotland.

Figured specimens.--USNM 125750A, B ; 125751, $125752 \mathrm{~A}-\mathrm{C}$ (A, B are unfigured external impressions of the figured impression of the interior).

Measured specimens.-USNM 125750-125752, 125754-125766, 125768-125771, 126328.

Unfigured specimens._-USNM 125767N, 125775S, $125776 \mathrm{~T}$.

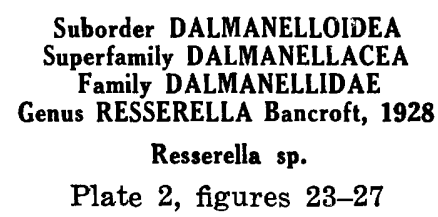

Exterior.-Brachial valve relatively flat, pedicle valve convex, naviculate in form. Straight hinge line, greatest width anterior of hinge line near midlength. Brachial valve interarea very steeply hypercline, pedicle interarea gently apsacline. Delthyrium and notothyrium apparently unmodified by plates. Anterior margin rectimarginate, crenulate. Lateral margins evenly rounded, shell outline slightly elongate to subcircular. Costellae increase by bifurcation.

Pedicle valve interior.-Short dental lamellae laterally bound posterior half of muscle field. Hinge teeth elongate, terminally crenulate. Muscle field tripartite with narrow, median, parallel-sided adductor impression laterally flanked by anteriorly expanding diductor impressions. Anterior and lateral shall margins strongly crenulate.

Brachial valve interior.-Cardinalia consist of prostrate, posteriorly directed cardinal process laterally flanked by stubby brachiophores and anteriorly joining low myophragm with rounded cross section. Cardinal process cleft medially by narrow slit. Dental sockets floored with crenulated fulcral plates. Medial face dental socket formed from brachiophore and posterior face by hinge line. Adductor impression divided medially by myophragm, bounded laterally by low ridges of secondary material that extends anteriorly from brachiophore base. Adductor impressions quadrilobate, divided by low ridge secon- 
dary material extending normal to midline. Anterior pair larger; whole adductor field elliptical in outline. Anterior and lateral margins of shell strongly crenulate.

Discussion.-The available material is inadequate for specific determination.

Occurrence.-USGS loc. 3479-SD, Spencer Lake quadrangle, Somerset County, Maine.

Stratigraphic location.-Base of Hobbstown Formation (Upper Silurian).

Figured specimens.-USNM 125772-125774.

Unfigured specimens.-USNM 125778-125780, 126112.

\section{Resserrella? sp.}

Discussion.—Single specimen from Hardwood Mountain Formation assigned questionably to Resserella because specimen has characteristic flat brachial valve and naviculate pedicle valve of genus.

Occurrence.-USGS loc. 3488-SD, Spencer Lake quadrangle, Somerset County, Maine.

Stratigraphic location.-Hardwood Mountain Formation (Upper Silurian).

Unfigured specimen.-USNM 125777.

\section{Subfamily ISORTHINAE \\ Genus ISORTHIS Kozlowski, 1929 \\ Isorthis sp. 1 \\ Plate 2, figures 28-32}

Exterior.-Unequally biconvex shells, pedicle valve having greater degree of convexity. Straight hinge line, greatest shell width near midlength. Pedicle valve interarea apsacline, brachial valve interarea anacline. Shell outline subcircular.

Brachial valve faintly sulcate. Anterior margin gently sulcate, crenulate. Pedicle valve interarea about two to three times as long as that of brachial valve. Shell lateral margins rounded. Costellae increase by bifurcation, crossed by concentric growth lines. Shell punctate.

Pedicle valve interior.-Hinge teeth bladelike, supported by short dental lamellae that form lateral margins of elongate muscle field. Muscle field contains elongate median adductor track whose anterior portion is raised up from floor of valve by secondary material, and paired, lateral, elongate diductor impressions which extend slightly anterior of adductor track margin. Shell interior relatively smooth, does not reflect external costellae.

Brachial valve interior.-Cardinalia consists of small prostrate cardinal process located between two large, bladelike, laterally diverging brachiophores. Brachiophores connected posteriorly to fulcral plates which serve to floor dental sockets. Posterior face of dental socket formed by palintrope. Brachiophores supported basally by brachiophore plates which diverge laterally, parallel to brachiophores. Sharp ridges extend anteriorly from brachiophore plates which surround muscle field laterally and finally converge medially before attaching to rounded, low myophragm which bisects muscle field. Myophragm extends from base of cardinal process to about midlength or to position slightly posterior. Muscle field quadripartite adductor impressions transversely divided by low ridges uniting medially with myophragm. Anterior and lateral margins finely crenulated.

Comparison.-Moose River synclinorium isorthids represented by relatively inadequate material, but meaningful comparisons may still be made. $I$. sp. 3 possesses a relatively narrow median adductor track in the pedicle valve which contrasts greatly with the relatively broad median adductor tracks of $I$. sp. 1 and 2. Subcircular adductor field in brachial valve of I. cf. I. perelegans contrasts strongly with the longitudinally elongate adductor field present in $I$. sp. 1, 2 , and 3. Pedicle muscle field in $I$. sp. 2 widens anteriorly in manner, differing considerably from $I$. sp. 1. I. sp. 1 has pedicle valve internal morphology similar in all regards to $I$. arcuaria, but inadequate material available makes specific determination premature.

Occurrence.-USGS loc. 3479-SD, Spencer Lake quadrangle, Somerset County, Maine.

Stratigraphic location.-Base of Hobbstown Formation (Upper Silurian).

Figured specimens.-USNM 125827-125829.

Unfigured specimens.-USNM 125830, 125831.

Isorthis sp. 2

Plate 2, figures 33-35

Discussion.-Single brachial valve from Hardwood Mountain Formation and single pedicle valve from Parker Bog Formation have characteristic internal features usually associated with Isorthis. Material too poor for specific identification.

Comparison.--See $I$. sp. 1.

Occurrence.-USGS loc. 3495-SD and 3487-SD, Spencer Lake quadrangle, Somerset County, Maine.

Stratigraphic location.-Hardwood Mountain Formation (Upper Silurian), and Parker Bog Formation (Lower Devonian).

Figured specimens.-USNM 125831A, 125826.

Unfigured specimens.-USNM 126329.

Isorthis sp. 3

Plate 3 , figures $1-16$

Exterior.-Valves unequally biconvex with pedicle valve about twice as deep as brachial valve. Valve outline tends to be transversely suboval. Hinge line 
straight and less than maximum width which occurs about midlength. External ornament not preserved.

Pedicle valve interior.-Hinge teeth supported by short, slightly divergent dental lamellae which are continuous anteriorly as subparallel or slightly anteriorly converging muscle bounding ridges. Diductor tracks enclosed by these ridges relatively narrow and rounded, separated by rounded ridgelike myophragm medially. Diductor tracks extend about $1 / 3$ to $2 / 5$ length of valve and not deeply impressed or elevated on platform anteriorly. Anterior very faintly crenulated by costae at margin of valves.

Brachial valve interior.-Sockets expand and diverge anterolaterally with what appear to be poorly developed fulcral plates at bases. Cardinal process base narrow, nearly linear; distal end not exposed. Adductor muscle scars enclosed by relatively broadly set-apart muscle bounding ridges that may or may not continue around posterior and anterior pairs. Two pairs about equal size and delineated by small ridges between posterior and anterior pairs; ridges are normal to midline. Low myophragm divides subtriangular posterior pair adductors. Dorsal margins, like those of pedicle valve, faintly crenulated by impress of costellae.

Comparison.-See I. sp. 1.

Occurrence.-USGS loc. 5587-SD, 5583-SD, 5586$\mathrm{SD}$, Attean quadrangle, Somerset County, Maine.

Stratigraphic location.-Hardwood Mountain Formation (Upper Silurian).

Figured specimens.-USNM 160113-160119.

\section{Isorthis cf. 1. perelegans (Hall, 1859)}

Plate 3, figure 17

Discussion.-Single brachial valve closely resembles Isorthis perelegans; convex, subcircular, slightly wider than long. Cardinal process flanked by widely diverging brachiophores that join anterolaterally with broadly spaced muscle bounding ridges which enclose rhomboidal muscle impression consisting of posterior and anterior adductor pairs.

Comparison.-See $I$. sp. 1.

Occurrence.-USGS loc. 3499-SD, Spencer Lake quadrangle, Somerset County, Maine.

Stratigraphic location.-Beck Pond Limestone (Lower Devonian).

Figured specimen.-USNM 125813.

Genus LEVENEA Schuchert and Cooper, 1931

Levenea sp.

Plate 3, figures 18-20

Exterior.-Biconvex shells with pedicle valve having greater convexity. Outline subcircular. Hinge line straight; greatest width about midlength. Later- al margins rounded; anterior commissure rectimarginate, crenulate. Radial costellae.

Pedicle valve interior.-Dental lamellae short and almost obsolete. Hinge teeth form not shown on Maine material. Muscle field tripartite with broad, anteriorly expanding median adductor track, whose anterior portion is raised up from valve floor by pad of secondary material, and relatively narrow, paired diductor tracks inclined almost normally to shell, placed in secondary material which fills valve posterior portion. Pallial marks paired; diverge anterolaterally from point where diductor impressions join adductor impression.

Brachial valve interior.-Cardinalia consist of cardinal process on bladelike base flanked laterally by stout brachiophores. Anteriorly brachiophores give rise to bladelike brachiophore plates. Anteriorly from brachiophore plates are subparallel musclebounding ridges. Muscle field medially divided by prominent, rounded myophragm.

Comparison.-Available material too poorly preserved and fragmentary for specific identification, but form resembles L. subcarinata (Hall. 1857).

Occurrence.-USGS loc. 3499-SD, Spencer Lake quadrangle, Somerset County, Maine.

Stratigraphic location.-Beck Pond Limestone (Lower Devonian).

Figured specimens._USNM 125811B, 125812, 125814.

Unfigured specimens.-USNM 125815 A-G.

\section{Unidentified orthoid \\ Plate 3, figure 21}

Discussion.-The only fossil recovered from the Lobster Mountain volcanics indicates a Middle Ordovician or younger age (presumably pre-Givetian in the absence of Givetian or younger marine beds in this region).

Occurrence._-USGS loc. 3280-SD, North East Carry quadrangle, Piscataquis County, Maine.

Figured specimen.-USNM 126473.

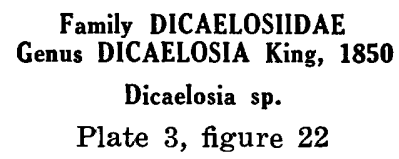

Exterior.-Small shells with strongly emarginate anterior margin; straight hinge line much narrower than greatest width which occurs forward of midlength. Shells biconvex with pedicle valve having somewhat greater convexity than brachial valve. Valves sulcate. Costellae and concentric growth lines.

Comparison.-No information regarding specific identity of Maine material is available because of 
fragmentary condition. No interiors of either valve are available for study.

Occurrence.-USGS loc. 3479-SD, 3488-SD, and 3499-SD, Spencer Lake quadrangle, Somerset County, Maine.

Stratigraphic location.-Hardwood Mountain Formation (Upper Silurian), base of Hobbstown Formation (Upper Silurian), and Beck Pond Limestone (Lower Devonian).

Figured specimen.-USNM 125810.

Unfigured specimen.-USNM 126330.

Family RHIPIDOMELLIDAE

Subfamily RHIPIDOMELLINAE

Genus DISCOMYORTHIS Johnson, 1970

Discomyorthis musculosa solaris (Clarke, 1907)

Plate 3, figures 23-25 plate 4, figures 1-3

Rhipidomella musculosa Hall var. solaris Clarke, 1907, p. 284, figs 1, 3, not fig. 2; Clarke, 1909, p. 88, pl. 21, figs. $8,10-11$, not fig. 9 .

Exterior.-Subcircular to transversely elliptical shells with narrow hinge line and interarea. Brachial valve more convex than almost flat pedicle valve. Pedicle valve commonly bears broad, low median sulcus. Greatest width near midlength. Interarea concave, gently apsacline in pedicle valve orthocline in brachial valve. Pedicle valve interarea about three times as long as that of brachial valve. Delthyrium unmodified by plates, but filled by cardinal process. Pedicle valve beak slightly incurved. Anterior commissure uniplicate and crenulate. Costellae increase by bifurcation. Growth lines concentric. Shell punctate.

Pedicle valve interior.-Stout hinge teeth border delthyrial cavity and project dorsally from anterior portion narrow interarea. Hinge teeth supported by short dental lamellae; almost obsolescent in large specimens. At base of dental lamellae lateral ridge continues anterolaterally to point slightly posterior of midlength and then turns anteromedially almost to surround muscle field. Muscle attachment area large, subcircular to transversely elliptical in outline, commonly reaches three-quarters of distance to anterior margin. Muscle field bisected by sharp low myophragm. Large, flabellate diductor impressions surround small, elongate, posteriorly situated adductor impressions.

Several radially disposed myophragms traverse diductor impressions. Posterior face delthyrial cavity occupied by pedicle callist; which is located on slightly raised pad of secondary material. Umbonal cavities commonly almost completely filled with secondary material. Anterior and lateral shell margins crenulated by flat crenulae which are grooved on upper faces. Valve interior, where not occupied by muscle impressions, relatively smooth due to deposition of secondary material.

Brachial valve interior.-Cardinalia consist of erect cardinal process which swells distally, has trifid posterior face, and joined posterolaterally with bladelike brachiophores. Brachiophores supported by brachiophore plates which form outer edge of dental sockets. Extending anteriorly from base of cardinal process is broad, low myophragm which bisects adductor impressions. Four adductor impressions, but posterior and anterior pairs not well differentiated. They extend anteriorly to position short of midlength. Anterior and lateral margins bear flat crenulae which may be grooved on upper faces.

Measurements.-The length:width scattergrams for Maine specimens show essentially linear growth curve with slope about $50^{\circ}$ (figs. $4 C, D$ ). Similar material from three Appalachian localities has a much smaller degree of dispersion than the Maine material, strongly suggesting that the Maine material is mechanically deformed to a large degree. The Maine material is normally distributed, which suggests that either small specimens have been abstracted or transportation and sorting has taken place. Degree of dispersion of the more highly convex brachial valves is greater than the relatively flat pedicle valves from Maine which suggests crushing has been important in producing dispersion. Amount of absolute variation increases with size increase, but there is no suggestion that percentage variation increases with size.

Distribution of three samples from the Appalachians suggests all have similar slopes and growth curves; degree of dispersion is of the same order of magnitude.

Relation between length and width of the diductor muscle field of the pedicle valve was studied (fig. $4 E$ ). The growth curve slope is about $40^{\circ}$ but the degree of dispersion is great which prevents, with present samples, estimating amount of departure from linearity. Considerable variation between diductor length and width suggests that this relation is not useful in specific characterization of rhipidomellids. It can be inferred that size and form of diductor field were not critical to the animal.

Figure $4 F$ shows the relationship between pedicle valve width and interarea width. Available information suggests a relatively linear relation; amount of dispersion is small. Slopes show a significant degree of difference between samples. Differences in slope are about $13^{\circ}$ for $D$. musculosa solaris and about $25^{\circ}$ for $D$. oblata. This relation emphasizes that interarea width appears to be a rhipidomellid character which remains relatively constant in any one sam- 
ple and has a wide variation span within a generic grouping. Inadequate information is available to determine whether differences should be accorded specific or generic rank.

Relationship between angle included by diductor muscle field (lateral ridge angle) and pedicle valve width is very variable (fig. $4 G$ ). The angle does not change consistently with change in specimen size. Degree of dispersion between samples is very great, but the significance of this difference is not apparent.

Relationship of left lateral ridge angle to right lateral ridge angle is random, as expected, of bilaterally symmetrical shells (fig. $4 H$ ) ; all samples exhibit about the same degree of dispersion and about the same angular relationships.

Relationship of pedicle valve width and width of diductor field is linear (fig. $4 B$ ), having a low degree of dispersion, indicating muscle field increases linearly with increase in shell width. Relationship between brachial valve width and angle included between the brachiophores is essentially random (fig. $4 A$ ), suggesting it remains constant with shell width increase.

Discussion.-This subspecies was first described by Clarke (1907), as a variety of Rhipidomella musculosa (Hall, 1857), from material collected by Olof Nylander. In the original description, "Moosehead Lake, Baker Brook Point; Brassua Lake, east side; Moose River at Stony Brook, Me." listed as localities (Clarke, 1907, p. 284). Later Clarke gave the same locality list (Clarke, 1909, p. 88); on page 208 of same volume, however, localities were assigned to four figured specimens (three previously figured in Clarke, 1907) - figures 8, 10, and 11 cited from Tomhegan Point, Moosehead Lake and figure 9 from Jackman farm. Because rocks and fossils of Oriskany age only occur on Tomhegan Point and Discomyorthis musculosa solaris is limited in range to beds of Schoharie age in this region, it seems clear that the specimens represented by figures 8,10 , and 11 were collected from beds of Schoharie age (probably on Baker Brook Point). Figure 9, representing a brachial valve, possesses the cardinalia and other characters of Platyorthis; therefore, it is reasonable that it was collected from beds of Oriskany age at Jackman farm.

Clarke's original description indicates that he founded his variety [sic] upon the characters of the pedicle valve: "These are all small shells with the enormous adductor [sic-adductor-diductor] scar in a state of high development. The shells are somewhat less circular, more transverse than in the New York and Grande Grève Oriskany specimens of $R$. musculosa, but their specific identity is not greatly veiled"
(Clarke, 1907, p. 284). It is recommended that $D$. musculosa solaris (Clarke, 1907) be retained for the form whose pedicle valves are figured in accordance with his implied intent.

Comparison.-Discomyorthis musculosa has a slightly wider interarea than $D$. musculosa solaris, but relationships between pedicle valve length and width and pedicle valve muscle field are very similar in both forms. D. oblata tends to have a smaller muscle field in the pedicle valve and wider interarea than does D. musculosa solaris. Discomyorthis alsa, although having characteristic marginal crenulations of Dalejina and Discomyorthis, does have a far wider interarea than do Discomyorthis oblata, Discomyorthis musculosa, or the form from Maine. Interarea of Discomyorthis eryna is similar to Discomyorthis alsa and may prove to be conspecific when adequate material of both species is studied.

Occurrence.-USGS locs., 2723-SD, 2730-SD, 2750-SD, 2752-SD, 2814-SD, 2820-SD, 2839-SD, 2840-SD, 2842-SD, 2852-SD, 2873-SD. Brassua Lake quadrangle, Somerset County, Maine.

Stratigraphic location.-Tomhegan Formation (Lower Devonian).

Distribution.-Northern Maine (Tomhegan Formation), northern New Hampshire (Littleton Formation), possibly Green Pond area of New Jersey if Kanouse Sandstone "Schizophoria sp. cf. S. striatula (Schlotheim)" Weller (1903) belongs to this species, and possibly "R. alsa? Hall" of Dunbar (1919) from western Tennessee (Camden Chert).

Holotype.-The interior impression of a pedicle valve figured by Clarke (1907, p. 284, right side of page, NYSM 8505) is here selected as the holotype.

Figured specimens.-USNM 125806-125809.

Unfigured specimens.-_USNM 126317-126327.

Measured specimens.-USNM 125806-125809, 125816.

\section{Discomyorthis sp. \\ Plate 4, figure 10}

Discussion.-Specifically unidentifiable Discomyorthis specimens have been obtained from Beck Pond Limestone (moderate size, up to $31 / 2 \mathrm{~cm}$ wide, relatively short hinge line, relatively restricted pedicle valve muscle field) and Discomyorthis sp. from McKenney Ponds Member of Tarratine Formation (moderate size, flat pedicle valve, relatively convex brachial valve, short hinge line, broadly flabellate pedicle valve muscle field).

Occurrence.-USGS locs. 3499-SD, Spencer Lake quadrangle, 2810-SD, 2806-SD, 2864-SD, Pierce Pond quadrangle, Somerset County, Maine.

Stratigraphic location.-Beck Pond Limestone 

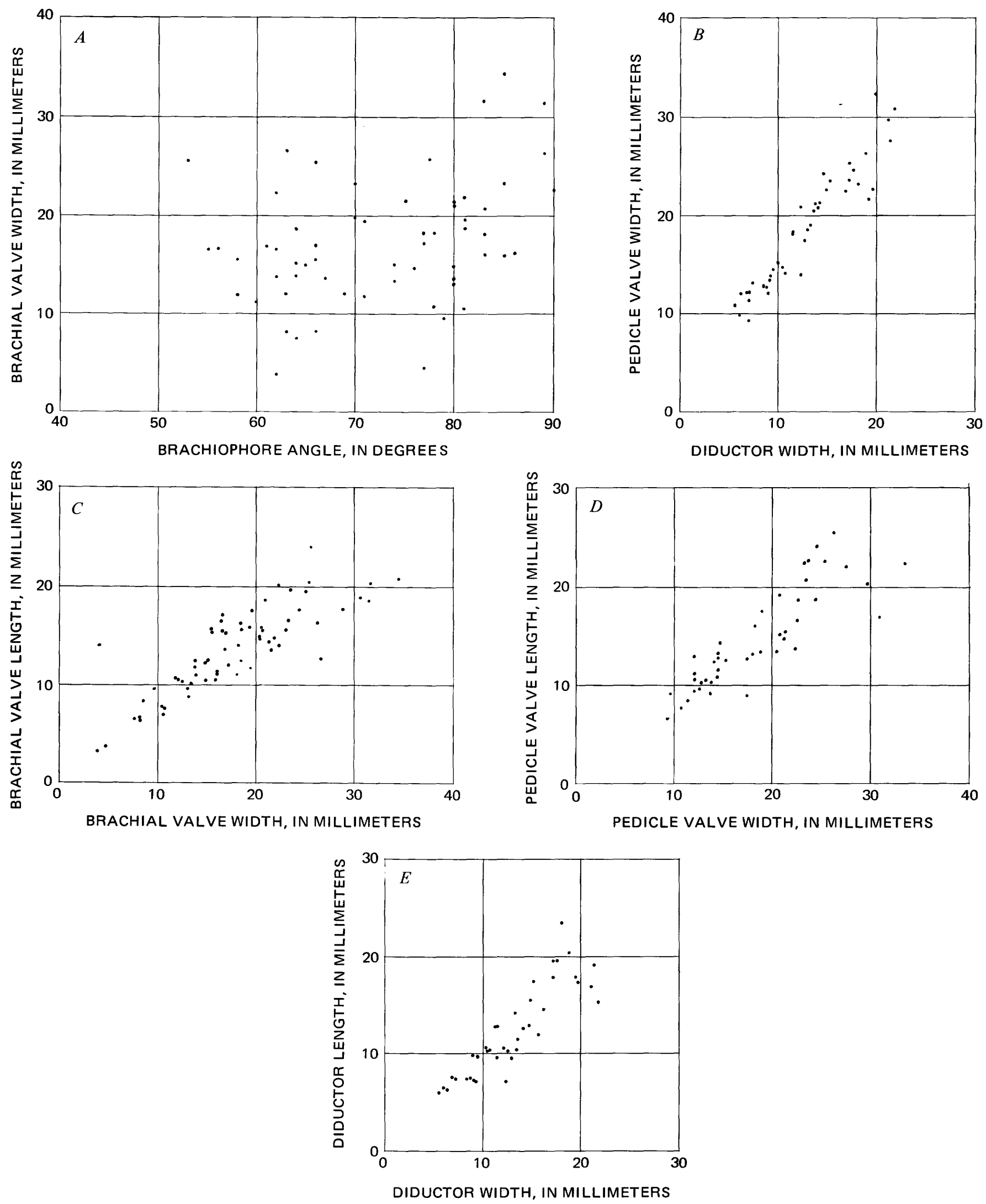

FIGURE 4.-Scattergrams for Discomyorthis musculosa solaris (Clarke, 1907) from the Tomhegan Formation. USGS loc. 2750-SD, Brassua Lake quadrangle, Somerset County, Maine. 

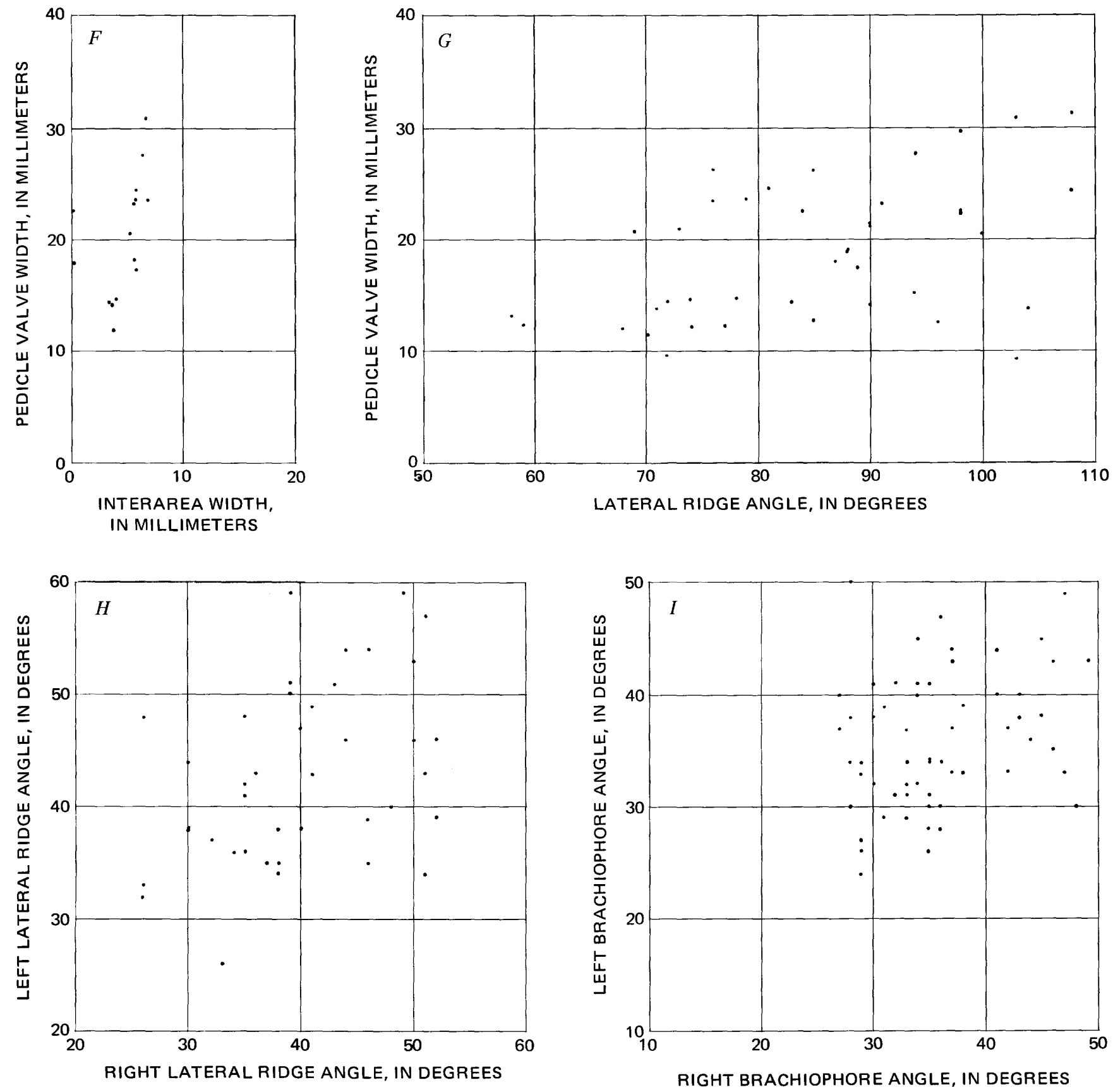

Figure 4.-Continued. 
(Lower Devonian) and McKenney Ponds Member of Tarratine Formation (Lower Devonian).

Figured specimen.-USNM 125823.

Unfigured specimens.-USNM 125821A,B, $125822 \mathrm{~A}, \mathrm{~B}$.

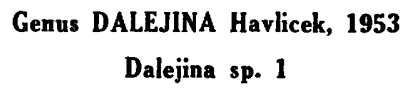

Plate 4, figures 6-9

Discussion.-The base of the Hobbstown Formation yielded one pedicle valve and one brachial valve possessing characters of Dalejina including flat crenulations with grooves on inner faces. Paucity of material and present difficulty in accurately defining already named species make it inadvisable to identify specifically Maine material. This subequally biconvex form, having short hinge line, small size, relatively small and nonflabellate pedicle muscle field, is similar to the Silurian species $D$. cliftonensis, $D$. newsomensis, and D. subtriangularis. Costellae of the form from the Hobbstown Formation are somewhat coarser than in the form from the underlying Hardwood Mountain Formation (species 2). The outline of Hobbstown Formation specimens is more like that of $D$. subtriangularis than of any other species mentioned above.

Occurrence.-USGS loc. 3479-SD, Spencer Lake quadrangle, Somerset County, Maine.

Stratigraphic location.-Base of Hobbstown Formation (Upper Silurian).

Figured specimens.-USNM 125821, 125822.

Dalejina sp. 2

Plate 4, figures 4, 5

Discussion.-A few poorly preserved specimens having Dalejina characters, including crenulate internal margin on which crenulae are flat and have grooved upper faces, were obtained from several localities in the Hardwood Mountain Formation. Pedicle and brachial valves subequally biconvex, short hinge line, relatively small and nonflabellate pedicle valve muscle field, and relatively fine costellae. Shell outline subcircular. Specimens similar to Silurian species enumerated under description of Dalejina sp. 1 from the base of the Hobbstown Formation; like it, inadequate for making specific identification. Hardwood Mountain Formation material has somewhat finer costellae than those from the base of the Hobbstown Formation.

Occurrence.-USGS locs. 2950-SD and 3469-SD, Spencer Lake quadrangle, Somerset County, Maine.

Stratigraphic location.-Hardwood Mountain Formation (Upper Silurian).

Figured specimen.-USNM 125824.
Unfigured specimens.-USNM 126346-126349, 126440-126442.

Dalejina? sp. or Discomyorthis? sp.

Discussion.-Parker Bog Formation yielded few very poorly preserved, highly deformed rhipidomellids that probably belong to Dalejina or Discomyorthis. Not possible to make positive assignment without information regarding crenulations along internal margins. Specimens have relatively short hinge line.

Occurrence.-USGS loc. 3477-SD, Spencer Lake quadrangle, Somerset County, Maine

Stratigraphic location.-Parker Bog Formation (Lower Devonian).

Subfamily PLATYORTHINAE

Genus PLATYORTHIS Schuchert and Cooper, 1931

Discussion.-In addition to the distinguishing characters of Platyorthis, described by Schuchert and Cooper (1931, p. 246) including the plano-convex profile and large, posteriorly reclining cardinal process, bifurcating crenulations occur along internal margins. These crenulations are unlike those of other members of the Rhipidomellidae, and therefore, serve to distinguish even fragmentary platyorthid material from other genera of the family.

Platyorthis planoconvexa (Hall, 1859)

Plate 4, figures 11-18

Platyorthis planoconvexa (Hall, 1859), see Boucot, 1959b, p. $739-740$, pl. 90 , figs. 3-10.

Exterior.-Brachial valve flat, pedicle valve convex and has carinate form. Shell outline subcircular with greatest width near midlength. Hinge line straight, very narrow, interarea small. Pedicle valve interarea concave, gently anacline to orthocline; brachial valve interarea anacline. Delthyrium unmodified, occupied by projecting cardinal process of opposite valve. Pedicle valve interarea about twice as long as that of brachial valve. Anterior commissure rectimarginate and crenulate. Pedicle valve beak slightly incurved. Costellae increase by bifurcation; crossed by concentric growth lines. Shell punctate.

Pedicle valve interior.-Stout, bladelike, laterally diverging hinge teeth supported by short dental lamellae. Hinge teeth posteriorly connected by small, horizontal plates flooring crural fossettes with posterior valve margin. Dental lamellae inner faces indented by crural fossettes. Umbonal cavities commonly almost filled with secondary material; consequently dental lamellae tend to become obsolete in larger specimens. Muscle field large, flabellate, commonly includes angle of about $30^{\circ}$, reaches from two- 
thirds to three-quarters distance to anterior margin, bisected by low, narrow myophragm. Muscle impressions divided into pair large diductor scars which expand anteriorly; divided by number of radially disposed, short myophragms into number of sectors. Small, elongate adductor impressions, poorly impressed posteriorly, abut pedicle callist. Pedicle callist located on posterior wall of delthyrial cavity upon small pad secondary material. Internal margins bear crenulae that bifurcate peripherally. Muscle field in large specimens bordered laterally by low, rounded ridge of secondary material that extends anteriorly from base of dental lamellae.

Brachial valve interior.-Cardinalia consist of posteriorly directed, terminally bifid cardinal process fused laterally with laterally diverging brachiophores. Brachiophores stout, supported by short brachiophore plates. Dental sockets anteriorly bordered by brachiophores and posteriorly by low ridge slightly anterior of interarea. Low ridges diverge in slightly anterolateral direction.

Muscle area transversely elliptical to subcircular in outline; restricted to posterior half of valve. Divided by low, rounded myophragm extending anteriorly to about midlength. Paired adductor impressions elliptical in outline; may be transversely divided by pair of low, transverse ridges into four impressions. Lateral portions muscle field bounded by low ridge of secondary material that extends anteriorly from base of brachiophore plates.

Measurements.-Relationship between brachial valve length and width suggests growth is relatively linear. Dispersion of Maine material is several times greater (fig. $5 A$ ) than undeformed material from New York (fig. $5 B$ ) suggesting that Maine material had linear dimensions altered mechanically. Maine material is normally distributed.

Comparison.-Orthis lucia Billings, 1874 is a junior synonym of Platyorthis planoconvexa, the former being described from the Grande Grève Limestone of Oriskany age. No criteria were observed that would enable one to discriminate between the platyorthids found in northern Maine and those known elsewhere in North America.

Occurrence.-USGS locs. 2701-SD, 3482-SD, 2721-SD, 2834-SD, 2691-SD, 2698-SD, 2700-SD, 2813-SD, 2777-SD, 2803-SD, 2719-SD, 2767-SD, 2860-SD, 3471-SD, 2862-SD, 2711-SD, 2751-SD, 2770-SD, 2710-SD, 2857-SD, 2870-SD, 2760-SD, 3474-SD, 2771-SD, 3093-SD, 2810-SD, 3486-SD, 2806-SD, 3229-SD, Somerset and Piscataquis Counties, Maine.

Stratigraphic location-Seboomook Formation (Lower Devonian), McKenney Ponds Member of the

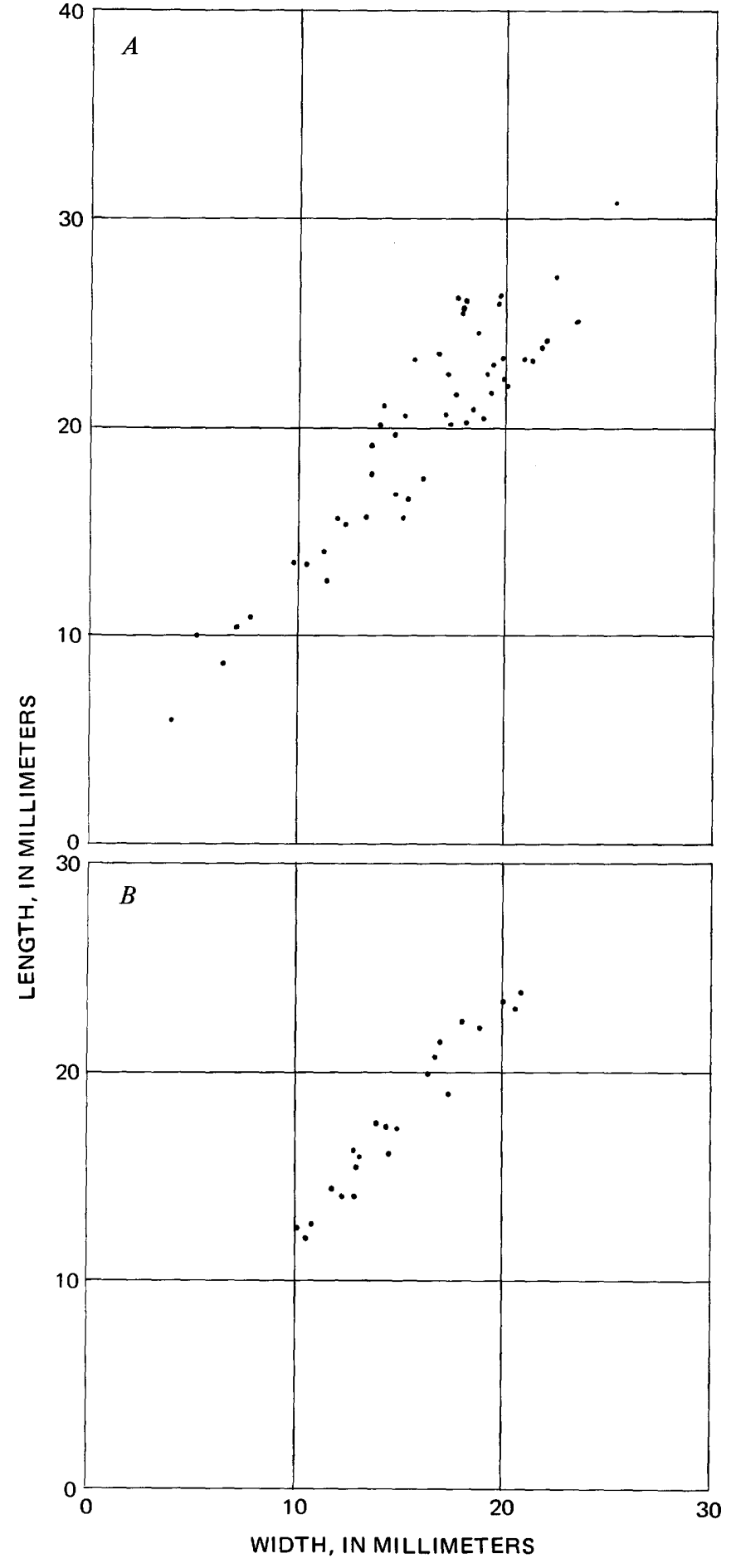

Figure 5.-Comparison of length versus width of brachial valves of Platyorthis planoconvexa (Hall, 1859). A, lower sandstone of the Tarratine Formation, USGS loc. 2701$\mathrm{SD}$, Brassua Lake quadrangle, Somerset County, Maine. $B$, Glenerie Limestone, on N.Y. Rte. $9 \mathrm{~W}, 1$ miles north of Glenerie and 1 mile south of Cockburn, N.Y.

Tarratine Formation, and the sandstones of the Tarratine Formation (Lower Devonian). 
Distribution.-The species is known from eastern North America. The European species Platyorthis circularis is similar in morphology.

Figured specimens.-USNM 125819, 125820, 125825.

Measured specimens.-125817.

Unfigured specimens.-USNM 125817, 126345, 125930-125939, 126350-126367.

\section{Superfamily ENTELETACEA \\ Family SCHIZOPHORIIDAE \\ Subfamily DRABOVIINE \\ Genus SALOPINA Boucot, 1960}

Salopina hitchcocki Walmsley, Boucot, and Harper, 1969

Plate 5, figures 1-11)

Salopina hitchcocki, Walmsley, Boucot, and Harper, 1969, p. $512-513$, pl. 71 , figs. $1-4$; pl. 72 , figs. $1-5$.

Exterior.-Unequally biconvex shells with evenly convex brachial valve and subconical pedicle valve. Hinge line straight, greatest width occurs about midlength. Lateral margins of shell rounded. Shell outline transversely elliptical. Brachial valve may bear low sulcus. Anterior commissure rectimarginate, crenulate; sulcate shells slightly emarginate. Brachial valve interarea steeply anacline; pedicle valve interarea steeply apsacline. Pedicle valve interarea about four to five times as long as that of brachial valve. Delthyrium unmodified. Costellae increase by bifurcation; crossed by concentric growth lines.

Pedicle valve interior.-Hinge teeth stout, located on medial edge of interarea. Hinge teeth supported by short dental lamellae which laterally bound cordate muscle field. Muscle field restricted to delthyrial cavity, located on slightly raised pad of secondary material. Ordinarily muscle field indivisible, on few specimens discernible median adductor track laterally bounded by elongate diductor impressions. Internal margins shell crenulate. External costellae impression not present on larger shells coated with secondary material, but evident on smaller specimens.

Brachial valve interior.-Cardinalia consist of linear, small, prostrate cardinal process laterally bounded by laterally divergent brachiophores. Brachiophores basally supported by laterally divergent brachiophore plates and posteriorly supported by fulcral plates. Fulcral plates floor dental sockets. Low, rounded myophragm extends anteriorly from cardinal process in some specimens (where deposition secondary material progressed) and serves, in these specimens, to separate deeply impressed muscle field. Such a myophragm commonly absent when specimen lacks deeply impressed muscle field. Muscle field quadripartite, subcircular outline, transversely subdivided by low ridges which join medially with myophragm. Muscle impressions subequal, anterior adductors larger, bounded laterally and anteriorly by ridge which begins at base of brachiophore plates, extends anteriorly then turns medially to join myophragm. Valve interior may be strongly crenulated by impression of external costellae, or smooth except for crenulations along internal margins in specimens where secondary material deposited.

Measurements.-Relationships of length and width of both valves are obscure in the sample studied because of the great amount of dispersion and relatively small size range of specimens (fig. 6). Relationship does appear linear. The amount of dispersion appears more than predicted for a small orthoid suggesting that physical deformation strongly affected specimens.

Comparison.- See Walmsley, Boucot, and Harper (1969) for discussion and comparison of the species assigned to Salopina.

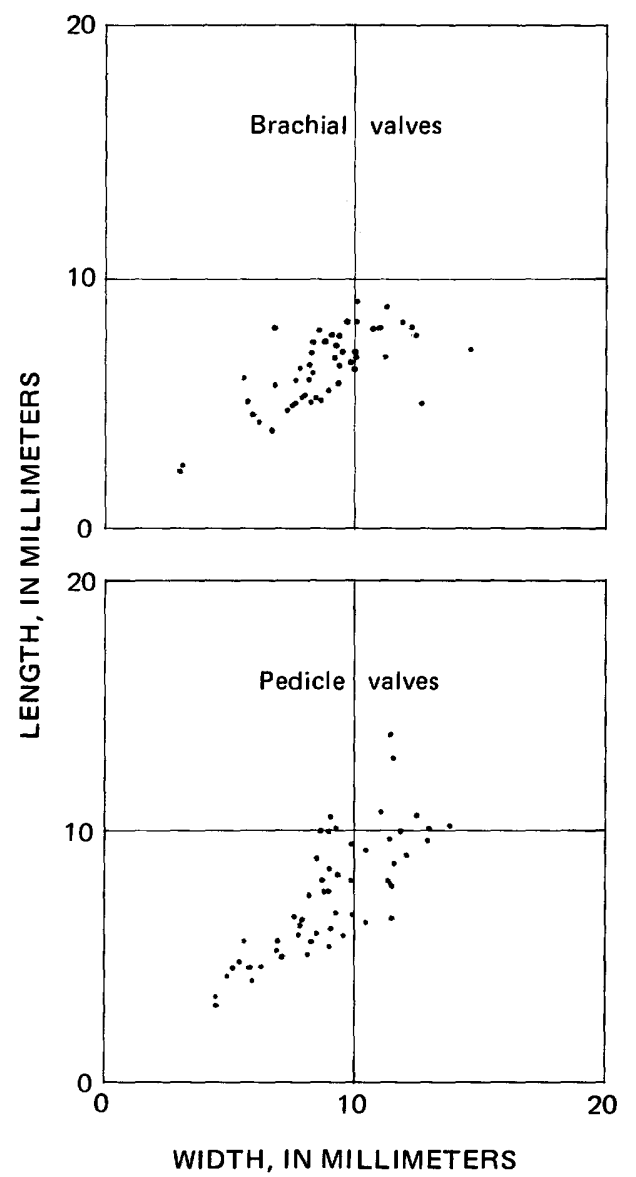

FIGURE 6.-Comparison of length versus width of brachial and pedicle valves of Salopina hitchcocki Walmsley, Boucot, and Harper, 1969. Tarratine Formation, Somerset County, Maine. 
Occurrence.-USGS locs. 2705-SD, 2720-SD, 2719-SD, 2722-SD, 2704-SD, 2711-SD, 2721-SD, 2743-SD, 2775-SD, 2861-SD, 2862-SD, 2872-SD, 2811-SD, 2729-SD, 2731-SD, 2890-SD, 2860-SD, 2727-SD, Somerset County, and 2884-SD, Piscataquis County, Maine.

Stratigraphic location.-Tarratine Formation (Lower Devonian), and Seboomook Formation (Lower Devonian).

Holotype.-USNM 125782.

Figured specimens.-USNM 125781-125783, 125793A, 125798.

Unfigured specimens.-USNM 126331-126344.

Measured specimens.-125784.

\section{Suborder PENTAMEROIDEA \\ Superfamily PENTAMERACEA \\ Family GYPIDULIDAE \\ Subfamily GYPIDULINAE \\ Genus GYPIDULA Hall, 1867 \\ Gypidula sp. 1}

Plate 5, figures 12-14

Exterior.-Unequally biconvex shells, pedicle valve possessing greater degree convexity. Neither fold nor sulcus appears present. Shell outline subcircular with lateral and anterior margins rounded. Anterior commissure apparently rectimarginate. Hinge line short, probably straight. Pedicle valve interarea incurved, very narrow, anacline; that of brachial valve not available. Delthyrium appears open, unmodified. Shell smooth; does not appear to possess fine ornamentation, spines, or granules.

Pedicle valve interior.-Small, posteriorly located spondylium consists of medially convergent dental lamellae supported by short median septum. Median septum striated by curved growth lines. Nature of hinge teeth not ascertained. Umbonal cavity very deep with spondylium near level of commissure. Anteriormost part of spondylium is free.

Brachial valve interior.-Outer portions brachial plates discrete, extend anteriorly about one-third length valve. Inner portions brachial plates short, apparently expand posteromedially.

Comparison.-Nonsulcate G. sp. 1 opposed to sulcate G. sp. 2.

Occurrence.-USGS loc. 3488-SD, Spencer Lake quadrangle, Somerset County, Maine.

Stratigraphic location.-Hardwood Mountain Formation (Upper Silurian).

Figured specimens.-USNM 126508, 126509A.

Unfigured specimens.-USNM 126373, 126374.

\section{Gypidula sp. 2}

Plate 5, figures 15-23

Exterior.-Unequally biconvex shells, pedicle valve having greater degree convexity. Brachial valve bears broad, shallow sulcus, pedicle valve corresponding fold. Shell outline subcircular to elliptical. Anterolateral margins rounded, hinge line short. Pedicle valve beak strongly incurved. Interarea very restricted. Shell exterior costate, about four costae in brachial valve sulcus, four on each flank. Anterior margin sulcate, crenulate.

Brachial valve interior.-Outer portions brachial plates discrete.

Comparison.-G. sp. 2 (two specimens available for study) ornamentation resembles G. coeymanensis, but lack of material precludes specific identification.

Discussion.-The specimen referred to by Woodard (1951, p. 76) and dated as "Siluro-Devonian" is shown on plate 5 , figures $15-19$.

Occurrence.-USGS loc. 2728-SD, Spencer Lake quadrangle, USGS loc. 5587-SD, Attean quadrangle, Somerset County, Maine.

Stratigraphic location.-Hardwood Mountain Formation (Upper Silurian).

Figured specimens.-USNM 125840, 160120.

\author{
Gypidula sp. 2? \\ Plate 6, figures 1-2
}

Exterior.-Unequally biconvex shells with pedicle valve having greater degree convexity. Neither fold nor sulcus appear present on material. Shell outline subcircular, anterior and lateral margins rounded. Hinge line short. Pedicle valve beak strongly incurved. Shell exterior costate, about fourteen low, rounded costae each valve.

Pedicle valve interior.-Small spondylium located posteriorly is supported by median septum extending anteriorly about one-half length of valve. Spondylium formed by convergent dental lamellae.

Brachial valve interior.-Short outer portions brachial plates rest on valve floor, slightly lateral to low, short myophragm which bisects (very poorly impressed) muscle field. Outer portions brachial plates long and extend anteriorly about one-third length of valve, somewhat concave medially. Posterior portions inner brachial plates turn laterally to form broad plates.

Discussion.-The single silicified brachial valve from USGS loc. 3485-SD has internal characters of Gypidula. Pedicle valve from loc. 3496-SD assigned to Gypidula because of similar ornamentation (no brachial valve recovered at this locality).

Occurrence.-USGS locs. 3496-SD, 3485-SD, Spencer Lake quadrangle, Somerset and Franklin Counties, Maine.

Stratigraphic location.-Hardwood Mountain Formation (Upper Silurian). 
Figured specimen.-USNM 125842.

Unfigured specimens.—USNM 126373, 126374.

\section{Genus SIEBERELLA Oehlert, 1887 \\ Sieberella beckensis Boucot, n. sp. Plate 6, figures $3-8$}

Exterior.-Biconvex shells, pedicle valve has greatest degree convexity. Outline transversely elliptical. Brachial valve bears broad, low sulcus, pedicle valve has corresponding fold. Hinge line straight, greatest width near midlength. Pedicle valve interarea steeply apsacline, slightly concave. Anterior commissure sulcate, crenulate. Pedicle valve fold and corresponding brachial valve sulcus develop at length about $6 \mathrm{~mm}$. Brachial valve beak incurved. Angular costae, increase by bifurcation, crossed by concentric growth lines. About three costae on fold, four to six on each flank. Sulcus commonly contains two costae.

Pedicle valve interior.-Small spondylium consists pair small medially conjunct dental lamellae supported by median septum. Median septum extends anteriorly about one-half valve length. Anterior and lateral portions interior reflect external ornamentation.

Brachial valve interior.-Outer plates medially conjunct, supported by median septum, inner plates turn laterally to form hinge plates. Dental sockets not worked out. Interior impressed by costae.

Comparison.-Sieberella beckensis is distinguished from $S$. sieberi by latter's greater number of costae on fold and sulcus, five to six and four to five respectively. $S$. roemeri has relatively lower, more rounded costae than S. beckensis.

Occurrence.-USGS loc. 3499-SD, Spencer Lake quadrangle, Somerset County, Maine.

Stratigraphic location.-Beck Pond Limestone (Lower Devonian).

Holotype.-USNM $125841 \mathrm{~A}$.

Figured specimens.-USNM 125841, 125839, 125837, 125838.

Unfigured specimens.-USNM 126375.

\section{Family PENTAMERIDAE \\ Subfamily PENTAMERINAE \\ Genus PENTAMERUS Sowerby, 1812 \\ Pentamerus? sp. \\ Plate 6, figures 9-10}

Exterior.-Evenly convex pedicle valve (no brachial valves found), interarea almost entirely obsolete. Beak incurved, anacline. Shell exterior smooth, open delthyrium appears unmodified. Cardinal margin terebratulid.

Pedicle valve interior.-Medially convergent dental lamellae form spondylium which extends anteriorly at least one-third valve length. Posteriormost portion delthyrial cavity longitudinally wrinkled.
Remarks.-Pending recovery of a brachial valve, generic identification is uncertain; both Pentamerus and Pentameroides have similar pedicle valves.

Occurrence.-USGS loc. 3475-SD, southern end of summit of Limestone Hill, Stratton quadrangle, Somerset County, Maine.

Stratigraphic location.-Lime-silicate hornfels of Early Silurian age.

Figured specimens.-USNM 125835-125836.

Unfigured specimens.-USNM 126372.

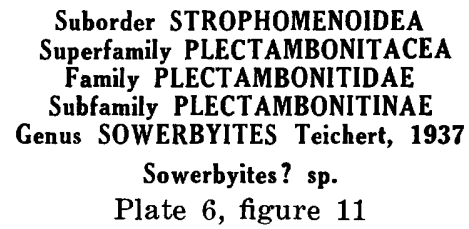

Exterior.-Brachial valve gently concave, pedicle valve evenly convex. Greatest width at straight hinge line. Lateral and anterior margins rounded. Anterior commissure rectimarginate. Pedicle valve interarea apsacline, that of brachial valve anacline. Radiating coarse and fine costellae crossed by concentric growth lines.

Remarks.-A few Kennebec Formation specimens possess exteriors resembling Sowerbyites ; in absence of information regarding internal structures, generic assignment these shells uncertain.

Occurrence.-USGS loc. 4317-CO, Brassua Lake qaudrangle, Somerset County, Maine.

Stratigraphic location.-Kennebec Formation (middle Middle Ordovician).

Figured specimens.-USNM 126152.

Unfigured specimens.-USNM 126676.

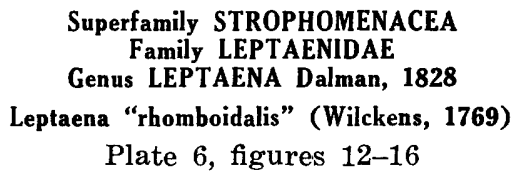

Leptaena "rhomboidalis" (Wilckens, 1769), see Boucot, 1959b, pl. 96, figs. 1-2.

Exterior.-Posterior portion brachial valve flat, anterior portion geniculate, shell has concave appearance. Posterior portion pedicle valve flat to gently convex, anterior portion geniculate. Shell outline transversely elliptical. Maximum width situated at straight hinge line. Fine, radiating costellae crossed by concentric wrinkles. Anterior and lateral margins rounded.

Pedicle valve interior.-Hinge teeth stubby. Muscle field deeply impressed, restricted to posterior half of valve, subcircular in outline, pair of narrow, median impressions flanked laterally by elliptical, relatively large, diductor impressions. Valve interior pustulose and uncorrugated due to deposition secondary material. 
Brachial valve interior.-Cardinalia consist of posteriorly bilobed cardinal process laterally supported by buttress plates, medially joining median septum which extends anteriorly to about midlength. Muscle field deeply impressed, consists of subcircular, posterior adductor impressions and elongate anterior adductor impressions laterally bounded by ridge secondary material. Pair of lateral septa occur at anterior part of muscle field.

Occurrence.-USGS loc. 3601-SD, 3400-SD, 2806SD, 3497-SD, 2730-SD, 3488-SD, 3475-SD, 3479SD, 3477-SD, 3499-SD, Somerset County, Maine.

Stratigraphic location.-Lime-silicate hornfels of Early Silurian age, base of Hobbstown Formation (Upper Silurian), Hardwood Mountain Formation (Upper Silurian), Parker Bog Formation (Lower Devonian), Back Pond Formation (Lower Devonian), McKenney Ponds Member of the Tarratine Formation (Lower Devonian), and the Tomhegan Formation (Lower Devonian).

Figured specimens.-USNM 126141, 126146, 126127.

Unfigured specimens.-USNM 127376-127383.

\section{Family STROPHEODONTIDAE \\ Subfamily STROPHEODONTINAE \\ Genus STROPHEODONTA Hall, 1852 \\ Stropheodonta cf. S. demissa (Conrad, 1842) \\ Plate 6, figures 17-19}

Exterior-Pedicle valve convex, brachial valve concave. Maximum width at straight hinge line. Outline subcircular. Posterior part lateral margin straight, anterior part rounded as is anterior margin. Anterior commissure rectimarginate, crenulate. Pedicle valve interarea orthocline, that of brachial valve hypercline. Interareas both valves short. Costellae with rounded cross sections separated by rounded interspaces. Costellae originate by bifurcation, crossed by concentric growth lines and filae.

Brachial valve interior.-Hinge line wholly denticulate. Cardinalia consist of bilobed cardinal process. Muscle field outline subcircular, extends anteriorly to about midlength. Median, small, elongate adductor impressions anteriorly pounded by breviseptum, laterally and anteriorly bounded by two pairs adductor impressions. Peripheral regions valve pustulose.

Comparison.-Ornamentation and form of Maine specimens are similar to $S$. demissa.

Occurrence.-USGS loc. 2820-SD, 2750-SD, Brassua Lake quadrangle, Somerset County, Maine.

Stratigraphic location.-Tomhegan Formation (Lower Devonian).

Figured specimens.-USNM 126145, 126144.

\section{aff. Stropheodonta sp.}

Plate 6, figures 20-23

Exterior.-Pedicle valve very convex and inflated. Maximum width located near midlengtn. Hinge line straight. Posterior part lateral margin relatively straight, anterior part and anterior margin rounded. Anterior commissure rectimarginate. Interarea relatively short, orthocline. Costellae coarser in umbonal region than peripherally, part of this apparent weakening may be due to abrasion. Outline variable. Pseudodeltidium covers delthyrium.

Pedicle valve interior.--Hinge line wholly denticulate. No dental lamellae observed although thickenings lateral to muscle field present. Two pits present lateral to well-developed median process. Muscle field weakly impressed to well impressed, paired posteromedial adductors separated by narrow depression, more broadly flabellate anterolateral diductor impressions.

Comparison.-This material does not belong to Stropheodonta s. s. as defined by Williams (1953, p. 34-35) because it lacks the coarse costellation of that genus. Unfortunately the available material is inadequate for specific description.

Occurrence.-USGS locs. 2820-SD, 2750-SD, Brassua Lake quadrangle, Somerset County, Maine.

Stratigraphic location.-Tomhegan Formation (Lower Devonian).

Figured specimens.-USNM 126126, 126153, 126125.

\section{Genus LEPTOSTROPHIA Hall, 1892}

Leptostrophia cf. L. magnifica (Hall, 1857)

Plate 7, figures 1-9)

Exterior.-Pedicle valve gently convex, brachial valve gently concave. Hinge line straight, maximum width near midlength. Lateral and anterior margins rounded. Anterior commissure rectimarginate. Pedicle valve interarea apsacline, relatively long, brachial valve interarea anacline, relatively short. Delthyrium open, includes angle of about $60^{\circ}-90^{\circ}$. Delthyrium apex occupied by secondary material. Shell outline subcircular. Fine costellae crossed by weak concentric wrinkles.

Pedicle valve interior.-Hinge line wholly denticulate. Cardinal process pits well defined, separated medially by ventral process. Ventral process narrow, posteriorly fills delthy'ial cavity, forms small pseudospondylium. Prominent lateral ridges diverge from delthyrial cavity margins, laterally bound flabellate muscle field. Lateral ridges include angle of $30^{\circ}-90^{\circ}$. Flabellate muscle field medially divided by low rounded ridge which extends anteriorly from ventral process to about midlength or position slight- 
ly anterior. Adductor impressions small, elliptical, situated just anterior of ventral process. Large, flabellate diductor impressions divided into number of radial sectors by series of myophragms. Umbonal cavities strongly pustulose.

Brachial valve interior.-Cardinal process lobes stout, laterally flanked by large socket plates. Small chilidium located between posterior portion cardinal process lobes. Wide low rounded ridge descends from cardinal process lobes to position posterior of midlength, becoming progressively narrower as it proceeds anteriorly. Adductor impressions relatively narrow, extend anteriorly to position slightly posterior of midlength. Umbonal region very pustulose lateral of muscle field, remainder of interior crenulated by external ornamentation impress.

Comparison.-The Maine specimens most strongly resemble $L$. magnifica, but the material is too poorly preserved for positive specific identification. No specimens have been assigned to Leptostrophia in the absence of the diagnostic brachial valve interior.

Occurrence.-USGS loc. 2700-SD, 2705-SD, 2710SD, 2813-SD, Somerset County, Maine.

Stratigraphic location.-Lower sandstone of the Tarratine Formation (Lower Devonian).

Figured specimens.-USNM 126121-126123, 126142, 126158, 126159.

Unfigured specimens._USNM 126155.

\section{Leptostrophia? sp. \\ Plate 7, figures 10, 11}

Remarks.-A few specimens from several preMoose River Group formations possess internal features that suggest assignment of the specimens to Leptostrophia. Cardinal process lobes well developed, flanked laterally by prominent socket plates. Hinge line at least partly denticulate. Pedicle valve musculature well impressed, bounding ridges subparallel anteriorly. None of this material well enough preserved to be specifically or generically assigned with confidence.

Occurrence.-USGS locs. 3477-SD. 3499-SD, 3483-SD, Spencer Lake and Pierce Pond quadrangles, Somerset County, Maine.

Stratigraphic location.-Hardwood Mountain Formation (Upper Silurian), Parker Bog Formation (Lower Devonian), and Beck Pond Limestone (Lower Devonian).

Figured specimens._USNM 126120, 126147.

Leptostrophia sp. or Protoleptostrophia sp. Plate 7, figures 12, 13

Discussion.-Leptostrophiid pedicle valves are abundant in the Lower Devonian formations, but, unfortunately, diagnostic brachial valves are rela- tively uncommon. In my opinion it is not possible to discriminate pedicle valves of Leptostrophia from those of Protoleptostrophia. The diagnostic characters of these genera are discussed under Protoleptostrophia.

Occurrence.-USGS locs. 2760-SD, 2857-SD, 2861-SD, 2832-SD, 2883-SD, 2864-SD, 3092-SD, 2819-SD, 2890-SD, 2877-SD, 2870-SD, 3088-SD, 2725-SD, 2761-SD, 2711-SD, 2698-SD, 2691-SD, 2708-SD, 2727-SD, 2749-SD, 2793-SD, 2795-SD, 2722-SD, 2785-SD, 2831-SD, 2823-SD, 2847-SD, 2860-SD, 2834-SD, 2777-SD, 2697-SD, 2775-SD, 2858-SD, Somerset and Piscataquis Counties, Maine.

Stratigraphic location.-McKenney Ponds Member, upper and lower sandstones of Tarratine Formation (Lower Devonian), and Seboomook Formation (Lower Devonian), Kineo Rhyolite (Lower Devonian).

Figured specimens.-USNM 126118.

\section{Genus PROTOLEPTOSTROPHIA Caster, 1939}

Comparison.-The discrimination of Leptostrophia and Protoleptostrophia is based primarily (Williams, 1953, p. 41) on the absence of socket plates and a prominent chilidium in the latter; and their presence in former. No reliable criteria for discriminating between pedicle valves of these two closely related genera have yet been determined.

\section{Protoleptostrophia cf. P. blainvillei (Billings, 1874) \\ Plate 8, figures 1-8}

Exterior.-Pedicle valve gently convex, brachial valve flat. Maximum width at straight hinge line. Lateral and anterior margins rounded. Anterior commissure rectimarginate. Pedicle valve interarea apsacline, brachial valve interarea anacline. Shell outline transversely elliptical. Fine costellae crossed by concentric growth line and subdued wrinkles.

Pedicle valve interior.-Cardinal process pits well defined, medially separated by short ventral process. Hinge line wholly denticulate. Lateral ridges bound flabellate muscle field, originate lateral to cardinal process pits, diverge at angle of about $90^{\circ}$ Umbonal cavities pustulose. Muscle field large, flabellate, extends to about midlength or a position slightly anterior and about half as wide as maximum width. Muscle impressions consist of pair small, elliptical adductor impressions located just anterior of ventral process and large, flabellate diductor field divided into radial sectors by number of short myophragms. Low ridge originates posteriorly at base of ventral process, bisects muscle field medially. Peripheral regions of interior crenulated by impress of external ornamentation. 
Brachial valve interior.-Cardinalia consist of stout cardinal process lobes joined anteriorly by broad notothyrial platform, laterally by lateral ridges. Notothyrial platform narrows anteriorly to median ridge which bisects muscle field. Lateral ridges diverge at angle about $90^{\circ}$, bound deeply impressed muscle field. Muscle field consists of anteriorly expanding adductor impressions restricted to posterior third of valve. Umbonal regions very pustulose, remainder of valve crenulated by impress external ornamentation.

Comparison.-Maine specimens are similar to $P$. blainvillei, but adequate comparative material is not available to make positive specific identification.

Occurrence.-USGS locs. 2730-SD, 2750-SD, 2814-SD, 2820-SD, 2839-SD, 2840-SD, 2852-SD, 2873-SD, Brassua Lake quadrangle, Somerset County, Maine.

Stratigraphic location.-Tomhegan Formation (Lower Devonian).

Figured specimens.-USNM 126140, 126137, 126154, 126136.

Unfigured specimens.-USNM 1273ð4, 127393127395.

\section{Protoleptostrophia sp. \\ Plate 8, figures 9-13}

Exterior.-Pedicle valve gently convex, brachial valve flat. Maximum width at straight hinge line. Outline subcircular to transversely elliptical. Anterior and lateral margins rounded. Anterior commissure rectimarginate. Pedicle valve interarea apsacline, relatively long; brachial valve interarea anacline, relatively short. Fine costellae crossed by concentric growth lines and weak wrinkles.

Pedicle valve interior.-Cardinal process pits deeply excavated, medially separated by short ventral process. Lateral ridges bound cardinal process pits laterally and laterally border flabellate muscle field. Narrow ridge extends from ventral process to muscle field front. Paired, elongate, small posteriorly situated adductor impressions and large, flabellate diductor impressions divided into radial sectors by short myophragms. Muscle field of variable length; may extend three-quarters distance to anterior margin and half valve width. Umbonal regions strongly pustulose. Valve peripheral portions crenulated by external ornamentation impress. Hinge line wholly denticulate.

Brachial valve interior.-Paired cardinal process lobes anteriorly bounded by broad, flat, notothyrial platform which narrows anteriorly into median ridge. Cardinal process lobes laterally bounded by diverging lateral ridges which bound muscle field and diverge at angle of about $90^{\circ}$ or more. Umbonal region strongly pustulose, remainder of valve crenulated by external ornamentation impress. Muscle field deeply impressed, consists of pair of anteriorly expanding adductor impressions restricted to posterior half of valve.

Comparison.-Maine material is too poorly preserved to be specifically identified.

Occurrence.-USGS locs. 2824-SD. 2699-SD, 2696-SD, 2719-SD, 2721-SD, 3090-SD, 2810-SD, 2767-SD, 2729-SD, 2770-SD, 2720-SD, 2718-SD, 2771-SD, 2701-SD, 2731-SD, Somerset County, Maine.

Stratigraphic location.-Lower sandstone of the Tarratine Formation (Lower Devonian).

Figured specimens.-USNM 126132-126135.

\author{
Genus STROPHONELLA Hall, 1879 \\ Strophonella cf. S. punctulifera (Conrad, 1838) \\ Plate 8, figures 14-18
}

Exterior.-Pedicle valve gently concave, brachial valve gently convex in large specimens; reverse condition true in small specimens, that is resupinate. Maximum width at straight hinge line. Pedicle valve interarea apsacline, brachial valve interarea steeply anacline. Interarea both valves moderate length. Lateral and anterior margins rounded. Costellae crossed by concentric growth lines. Small pseudodeltidium appears to be present at delthyrium apex. Brachial valve chilidium not certain. Anterior commissure rectimarginate.

Pedicle valve interior.-Hinge line denticulate about half its length. Small cardinal process pits located either side of short ventral process. Muscle field not discernible on specimen studied. Interior crenulated by external ornamentation impress.

Brachial valve interior.-Cardinal process lobes flanked laterally by narrow socket plates which parallel hinge line. Short notothyrial platform extends anteriorly from cardinal process lobes and narrows rapidly. Very short lateral ridges bound muscle field. Muscle field restricted to valve posterior, consists of subcircular, small adductor impressions. Valve interior very pustulose except periphery which is crenulated by external ornamentation impress.

Comparison.-Strongly resembles strophonellids from Lower Devonian like $S$. punctulifera. and $S$. ampla. Pedicle valve musculature is not well marked in the petaloid fashion characteristic of many strophonellids, but this may be due to the small size of the specimen studied. Dental plates are absent on the only pedicle interior studied.

Occurrence.-USGS loc. 3477-SD, Pierce Pond quadrangle, Somerset County, Maine. 
Stratigraphic location.-Parker Bog Formation (Lower Devonian).

Figured specimens.-USNM 126119, 126157, 126143.

Unfigured specimens._USNM 126161.

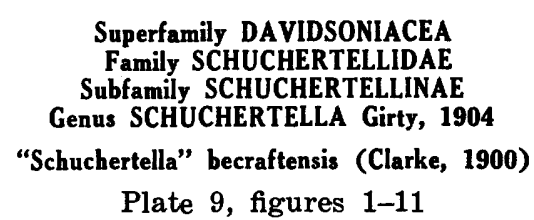

Orthotetes becraftensis (Clarke, 1900), p. 51-52, pl. 7, figs. 15-28.

Exterior.-Unequally biconvex shells, brachial valve gently convex, pedicle valve subconical. Greatest width near midlength. Hinge line straight. Pedicle valve interarea steeply apsacline to catacline, brachial valve interarea steeply anacline. Delthyrium closed by convex pseudodeltidium; apical portion notothyrium bounded by ribbonlike chilidium. Pedicle valve interarea relatively long, brachial valve interarea short. Shells subsemicircular in outline. Closely spaced costellae, rounded in cross section, separated by rounded interspaces. Costellae originate by implantation and bifurcation. Lateral and anterior margins rounded. Anterior commissure rectimarginate, crenulate.

Pedicle valve interior.-Stout hinge teeth border sides of delthyrium, supported basally by own tracks. Track may be anteriorly supported by lamellar deposit of secondary material which simulates dental lamella. Muscle field semicircular, poorly impressed; consists of bilobate field restricted to posterior third of valve. Peripheral regions of interior crenulated by impress of external ornamentation, remainder smooth due to deposition of secondary material.

Brachial valve interior.-Bilobed cardinal process, posteriorly extends behind hinge line, fused anteriorly to laterally diverging buttress plates which include angle of about $90^{\circ}$. Dental sockets excavated between interarea and socket plates. Adductor muscle field lightly impressed, extends anteriorly to about midlength. Interior crenulated by external ornamentation impress.

Comparison.-Maine material appears to be "S." becraftensis. Generic assignment not certain because of no modern consideration of taxonomy and morphology of Silurian-Devonian orthotetaceans.

Occurrence.-USGS locs. 2721-SD, 2719-SD, 2720-SD, 2810-SD, 3091-SD, 2722-SD, 2806-SD, 2777-SD, 2767-SD, 2761-SD, Somerset County, Maine.

Stratigraphic location.-McKenney Ponds Member of the Tarratine Formation, lower sandstone of the Tarratine Formation, and Seboomook Formation.

Figured specimens.-USNM 126139, 126156, $126124,126138,126160,126162,126151$.

Unfigured specimens._USNM 127367, 127369, 127371.

\author{
"Schuchertella" sp. \\ Plate 9, figures 12-14
}

Brachial valve exterior.-Brachial valve evenly convex. Maximum width is slightly posterior of midlength. Straight hinge line, interarea steeply anacline, short. Ribbonlike chilidium borders notothyrium. Costellae originate by bifurcation and implantation. Lateral and anterior margins rounded. Anterior commissure rectimarginate, crenulate.

Brachial valve interior.-Posteriorly bilobed cardinal process anteriorly fused with buttress plates, anteromedially joined by short, rounded septumlike ridge. Socket plates diverge at angle of about $90^{\circ}$. Muscle field impressed, consists of elongate, elliptical adductor impressions medially divided by median ridge. Muscle field restricted to posterior third of valve.

Comparison.-Maine material is too fragmentary to be specifically identified.

Occurrence.-USGS locs. 2814-SD, 2820-SD, 2750-SD, 2730-SD, Brassua Lake quadrangle, Somerset County, Maine.

Stratigraphic location.-Tomhegan Formation.

Figured specimens._USNM 126148.

Unfigured specimens.-USNM 127362-127366, 127368, 127370, 127372, 127373.

\section{Genus HIPPARIONYX Vanuxem, 1842 \\ Hipparionyx sp. \\ Plate 9, figures 15-17}

Exterior.-Unequally biconvex shells with highly convex brachial valve, almost flat pedicle valve. Shell outlines subcircular. Greatest width near midlength, hinge line very narrow. Lateral, posterior, and anterior margins rounded. Anterior commissure rectimarginate, crenulate. Rounded costellae.

Pedicle valve interior.-Muscle field flabellate, extends about two-thirds distance to anterior margin and one-half distance to lateral margins. Posterior portion muscle field bounded by lateral ridges originating posteriorly at base of hinge teeth. Muscle field tripartite, consists of posterior, medially situated, elongate adductor impression anterior of which are paired, elliptical diductor impressions medially separated by low ridge. Peripheral region of valve crenulated by external ornamentation impress.

Brachial valve interior.-Posteriorly bifid cardinal process anteriorly fused with laterally diverging 
buttress plates. Myophragm situated at anterior edge of cardinal process. Muscle field impression not discernible.

Comparison.-Maine material is too poorly preserved to be specifically identifiable.

Occurrence.-USGS locs. 2806-SD, 2810-SD, Pierce Pond quadrangle, Somerset County, Maine.

Stratigraphic location.-McKenney Ponds member of the Tarratine Formation (Lower Devonian).

Figured specimens.-USNM 126150, 126149.

Unfigured specimens.-USNM 127374, 127375.

Family STROPHOMENIDAE
Subfamily LEPTAENOIDEINAE
Genus LEPTAENISCA Beecher, 1890
Leptaenisca sp.
Plate 9 , figures $18-20$

Pedicle valve exterior.-Pedicle valve highly convex. Valve outline asymmetrical. Broad cicatrix which may have been formed by attachment against the stem of a crinoid present on one specimen. Radiating coarse and fine costellae crossed by concentric growth lamellae. Lateral and anterior margins irregularly rounded. Maximum width is slightly anterior of midlength. Shell transversely elliptical. Hinge line relatively straight. Anterior commissure rectimarginate.

Pedicle valve interior.-Muscle field strongly impressed, consists of paired, elongate scars restricted to umbonal region. Rounded ridge medially separates muscle scars. Muscle field laterally bounded by ridge of secondary material. Umbonal cavities pustulose, due to presence of pseudopunctae.

Comparison.-Maine specimens are not well enough preserved to be identified specifically. However, they do resemble $L$. australis Kindle.

Occurrence.-USGS loc. 3499-SD, Spencer Lake quadrangle, Somerset County, Maine.

Stratigraphic location.-Beck Pond Limestone (Lower Devonian).

Figured specimens.-USNM 126128, 126129.

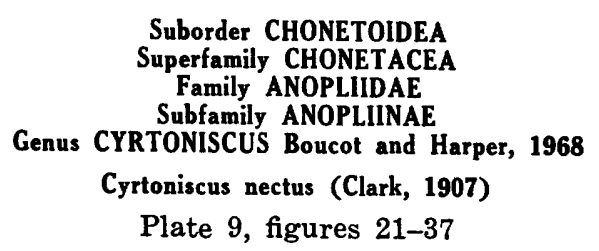

Cyrtoniscus nectus (Clarke, 1907), see Boucot and Harper, 1968, p. 172-173, pl. 30, figs. 6-13.

Exterior.-Pedicle valve strongly convex posteriorly, changes convexity abruptly at length of about $2 \mathrm{~mm}$. Small shells, posterior part of larger shells subhemispherical. Shell outline circular to transversely elliptical (deformation greatly distorted outline of specimens from Maine). Hinge line straight, maximum width located near midlength. Brachial valve gently concave, does not show abrupt change in convexity from posterior to anterior as opposed to shape of pedicle valve. Interareas virtually undeveloped except in medial part of pedicle valve where anacline. Delthyrial and notothyrial cavities appear unmodified. Anterior margin rectimarginate, crenulate. Anterior and lateral margins rounded. Radial costae, crossed by fine concentric lines, costae increasing anteriorly by bifurcation and implantation. The relation between length and width shown in figure 7. One pair of spines extends laterally from ears; from two to ten spines occur along posterior margin of pedicle valve.

Brachial valve interior.-Posteriorly directed, terminally bifid cardinal process, which seals off delthyrium and laterally directed socket ridges. Dental sockets formed medially by edge of cardinal process, anteriorly by socket ridges, and posteriorly by poorly developed interarea. Median septum not present although cardinal process continues anteriorly for short distance as notothyrial platform. Accessory septa radiate from cardinalia, reach almost to anterior margin. Anderidia minute. Interior highly pustulose. External ornamentation impress general.

Pedicle valve interior.-Stubby hinge teeth continuous with reduced interarea, unsupported by dental plates. Narrow median septum divides muscle field, extends anteriorly to position where change in shell convexity takes place. Hollow spine bases present along hinge line. External ornamentation impression present near anterior margin.

Measurements.-Relationship between length and width of pedicle valve (fig. 7) is linear, with a high degree of dispersion which is probably a function of mechanical deformation.

Occurrence.-USGS locs. 2723-SD, 2750-SD, 2752-SD, 2814-SD, 2820-SD, 2842-SD, 2852-SD, 2873-SD, Brassua Lake quadrangle, Somerset County, Maine.

Stratigraphic location.-Tomhegan Formation (Lower Devonian).

Figured specimens.-USNM 126222, 126223, $126227-126229,126231,126247,126248,127391$, 127392.

Unfigured specimens._USNM 127361, 127396.

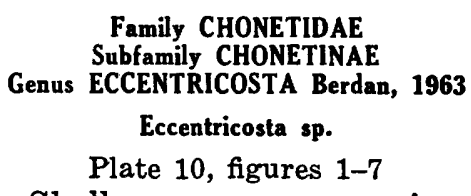

Plate 10, figures 1-7

Exterior.-Shells concavo-convex in cross section, pedicle valve gently convex. Maximum width probably near hinge line. Lateral and anterior margins 


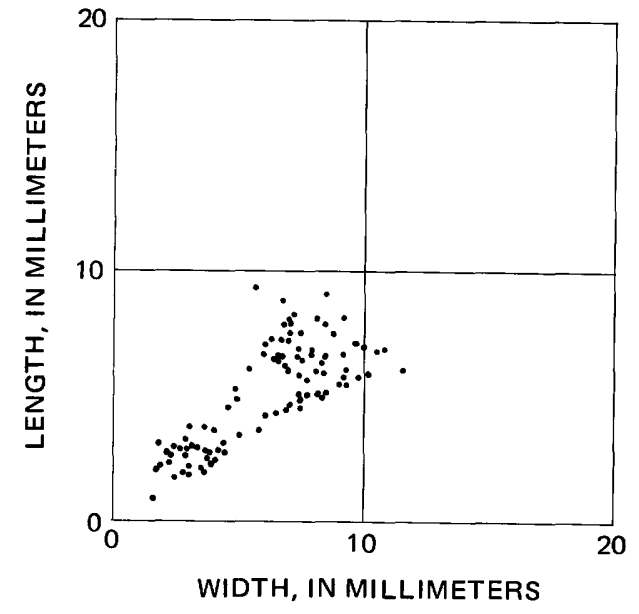

FiguRE 7.-Comparison of length versus width for pedicle valves of Cyrtoniscus nectus (Clarke, 1907). Tomehegan Formation, USGS loc. 2852-SD, Brassua Lake quadrangle, Somerset County, Maine

evenly rounded and crenulate. Pedicle valve interarea apsacline, planar. Deltidium fills delthyrium. Deltidium very convex posteriorly. Brachial valve interarea not observed; presumably very narrow. Both valves transverse in outline. Relatively coarse, undulating costellae originate by implantation peripherally and along posterior margin posteriorly. About five or six short spines on each side of pedicle valve midline.

Interior.-Internal features poorly preserved on available specimens; little noted except presence of short, thin septum in interior of pedicle valve beak.

Remarks.-Berdan (1963, p. 254) noted that costellae originate by bifurcation; I would prefer implantation and bifurcation, as few defined junctions were observed in material illustrated by Berdan or in specimens from Maine. Maine specimens are too poorly preserved to be identified specifically.

Occurrence.-USGS locs. 4841-SD, 5583-SD, 5586-SD, 5995-SD, Attean quadrangle, Somerset County, Maine.

Stratigraphic location.-Hardwood Mountain Formation (Upper Silurian).

Distribution.-The genus is known from the central Appalachians (Berdan 1963, p. 256), and I have observed it in Late Silurian collections from western Gaspé, the Fish River Lake quadrangle in Maine, and near Marbleton in the Eastern Townships of Quebec.

Figured specimens.-USNM 160121, 160126.
Genus DAWSONELLOIDES Boucot and Harper, 1968

Dawsonelloides canadensis (Billings, 1874)

Plate 10, figures 8-12; plate 11, figures 1-7

Dawsonelloides canadensis (Billings, 1874), see Boucot and Harper, 1968, p. 166-167, pl. 28, figs. 17-21; pl. 29, figs. 1-3.

Exterior.-Pedicle valve gently convex, brachial valve gently concave. Maximum width located at straight hinge line. Shell subsemicircular to quadrate in outline. Posterior portion lateral margin straight, anterior portion and lateral margin rounded. Pedicle valve interarea apsacline, brachial valve interarea steeply anacline to hypercline. Interareas both valves moderately long. Convex pseudodeltidium occupies apex of delthyrium. Discrete chilidial plates border notothyrium. Hollow spines border lower edge of pedicle valve interarea. Number of spines variable, does not exceed ten in specimens studied. Anterior margin rectimarginate. Fine costellae interrupted by concentric growth lines, give reticulate appearance.

Pedicle valve interior.-Hinge teeth stout, unsupported by dental lamellae. Distally and medially hinge teeth deeply grooved to receive socket ridges of brachial valve for articulatory purposes. Median septum extends to about midlength anteriorly. Median septum low in delthyrial cavity, but rises rapidly to form winglike blade, descends abruptly at about one-quarter distance to anterior margin, then extends to about midlength as low septum. Delthyrial cavity partly filled by secondary shell material. Muscle bounding ridges laterally border flabellate diductor field. Muscle field about half width of shell, extends anteriorly to about midlength. Interior of valve very pustulose, due to projecting pseudopunctae. Radiating from posteromedial portion of shell are ridges separated by broad, rounded interspaces. Ridges bifurcate anteriorly.

Brachial valve interior.-Posterior facing cardinal process consisting of two cardinal process lobes fused medially in large specimens. Short chilidial plates occur posterolaterally of cardinal process lobes. Anteriorly cardinal process lobes join median septum which extends to about midlength. Lateral to cardinal process lobes are socket plates which curve and extend parallel to hinge line. Pair of anderidia in posteromedial portion of interior laterally enclose paired adductor field. Anderidia include angle of about $60^{\circ}$. Interior very pustulose. Ridges radiate from umbonal region, separated by broad interspaces. Ridges bifurcate peripherally.

Measurements.-Relationship between length and width of pedicle valves appears linear (fig. 8), but small size of sample precludes definite conclusion. 


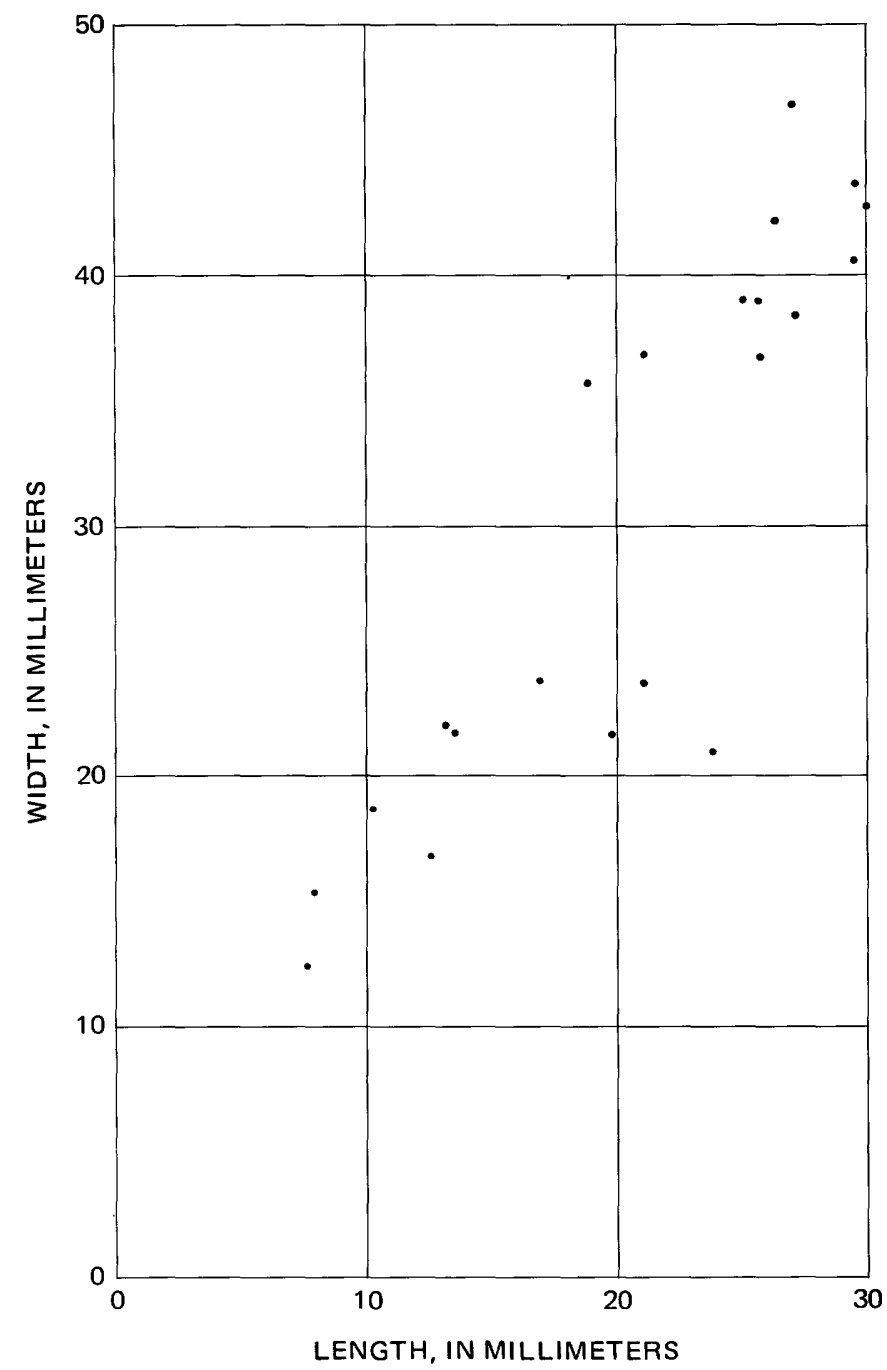

Figure 8.-Comparison of length versus width of pedicle valves of Dawsonelloides canadensis (Billings, 1874). Lower sandstone of Tarratine Formation, USGC loc. 2701-SD, Brassua Lake quadrangle, Somerset County, Maine.

Occurrence.-USGS locs. 2701-SD, 2710-SD, 2711-SD, 2705-SD, 2704-SD, 2699-SD, 2703-SD, 2708-SD, 2861-SD, 2872-SD, 2743-SD, 2725-SD, 2801-SD, 2696-SD, 2700-SD, 2860-SD, 2847-SD, 2812-SD, 2766-SD, 2813-SD, 2740-SD, 2776-SD, 3486-SD, 2857-SD, 3090-SD, 2849-SD, 3089-SD, 2770-SD, 2767-SD, 2777-SD, 2797-SD, 2783-SD, 2803-SD, 2799-SD, 2807-SD, 2771-SD, 2802-SD, 2830-SD, 3482-SD, 2890-SD, 2706-SD, 3476-SD, Piscataquis and Somerset Counties, Maine.

Stratigraphic location.-Seboomook Formation (Lower Devonian), and sandstones of the Tarratine Formation.

Figured specimens.-USNM 126250, 126245, $126253,126239,126251,126244,126252,126246$, 126233.
Unfigured specimens.-USNM 126249.

Measured specimens.-USNM 126705.

\author{
Genus EODEVONARIA Breger, 1906 \\ Eodevonaria arcuata (Hall, 1857) \\ Plate 11, figures 8-16
}

Eodevonaria arcuata (Hall, 1857), see Boucot and Harper, 1968, p. 153-156, pl. 27, figs. 1-7.

Exterior.-The pedicle valve is highly convex and the brachial valve is gently concave. Body cavity narrow. Hinge line straight, maximum width located at hinge line. Shell outline subcircular to elliptical (deformation has changed outline of many specimens). Ears flattened. Pedicle valve interarea orthocline to gently apsacline, brachial valve interarea hypercline. Delthyrium completely closed by convex pseudodeltidium, notothyrium closed by convex chilidium. Pedicle valve interarea about three times as long as that of brachial valve. Anterior margin rectimarginate. Spines originate at base of pedicle valve interarea, but very rare and seldom observed. Hinge line denticulation visible at junction of two interareas. Costellae originate largely by bifurcation. Costellae undulate gently, do not increase in width anteriorly. Costellae low, rounded in cross section, separated by interspaces of similar form. Number of spines along posterior margin of pedicle valve has not been observed to exceed eight.

Pedicle valve interior.-Two stubby, laterally directed hinge teeth situated anterior of delthyrial cavity and hinge line, just bordering edges of delthyrium. Low median septum extends from delthyrial cavity to about midlength. Hollow spine bases rarely seen along junction of interarea and bottom of valve. Two posterolateral ridges diverge from midline and interlock with corresponding anterolaterally directed posterior ridges of brachial valve. Interior of ears pustulose, remainder of interior bears impress of external ornamentation in addition to being pustulose. Muscle field very weakly impressed, consists of two pairs of elongate impressions paralleling median septum, plus small pair posteriorly located, oval impressions.

Brachial valve interior.-Fused, prostrate, posteriorly directed cardinal process lobes. Lateral to base of cardinal process lobes are anterolaterally directed socket ridges. Low platform of secondary material, anterior of fused cardinalia, trifurcates anteriorly into median septum extending to midlength and into two anderidia which enclose muscle field. Near anterior portion of median septum may be developed pair of accessory septa. Valve interior pustulose posteriorly, peripherally crenulated by impress of external ornamentation. Muscle field con- 
sists of paired, elongate adductor impressions which parallel median septum.

Measurements.-The relationship between length and width of pedicle valves is essentially random with a high degree of dispersion (fig. 9). This condition reflects the fact that the specimens were selected from a very small size range and that they have been subjected to a high degree of mechanical deformation.

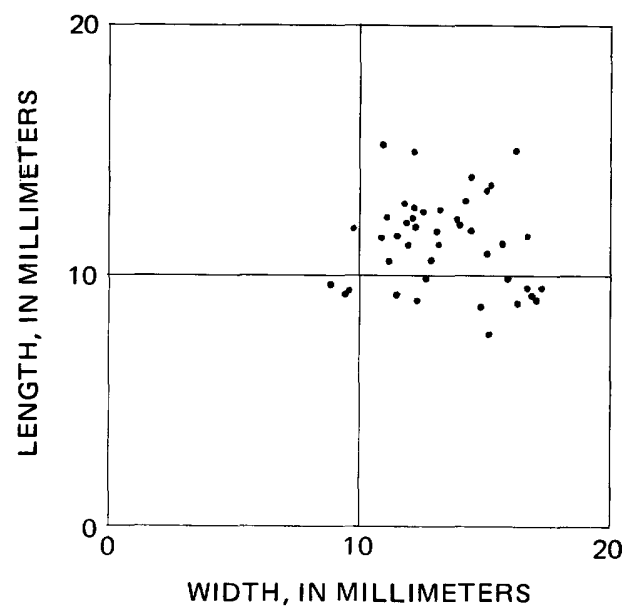

Figure 9.-Comparison of length versus width of pedicle valves of Eodevonaria arcuata (Hall, 1857). Tomhegan Formation, USGS loc. 2820-SD, Brassua Lake quadrangle, Somerset County, Maine.

Occurrence.-USGS locs. 2820-SD, 2750-SD, 2852-SD, 2814-SD, 2839-SD, 2873-SD, 2840-SD, Brassua Lake quadrangle, Somerset County, Maine.

Stratigraphic location.-Tomkegan Formation.

Distribution.-Eastern North America.

Figured specimens.-USNM 126230, 126234, 126235, 126232, 126238, 126226.

Unfigured specimens.-USNM 126224.

Measured specimens.-126677A-126677AN.

Subfamily CHONOSTROPHIELLINAE

Genus CHONOSTROPHIELLA Boucot and Amsden, 1964

Chonostrophiella complanata (Hall, 1857)

Plate 11, figures 17-25; plate 12, figures 1, 2

Chonostrophiella complanata (Hall, 1857), see Boucot and Amsden, 1964, p. 881-882, pl. 141, figs. 1-11.

Exterior.-Pedicle valve flat or gently concave except in strongly concave peripheral region. Brachial valve gently convex. Maximum width located on straight hinge line. Pedicle valve interarea catacline to steeply apsacline, brachial valve interarea steeply anacline. Pedicle valve interarea relatively long, brachial valve interarea relatively short. Delthyrium usually open, includes angle of about $90^{\circ}$ except in few specimens that have a small pseudodeltidium located apically. Notothyrium modified laterally by small chilidial plates which extend medially almost to midline but have not been observed in conjunct state. Fine, radial costellae originate by both bifurcation and implantation, crossed by closely spaced concentric ornamentation that results in granulose effect. Shell outline transversely elliptical. Posterior part of lateral margin straight but anterior part and anterior margin gently rounded. Anterior commissure rectimarginate. Base of pedicle valve interarea bears short spines (three to seven on each side of midline).

Pedicle valve interior.-Very short dental lamellae support spatulate hinge teeth. Dental lamellae diverge at angle between about $90^{\circ}$ and $120^{\circ}$. Dental lamellae enclose posterior part of poorly impressed muscle field. Muscle impressions posterolaterally delineated by bounding ridges which extend from base of dental lamellae. Diductors compose bulk of muscle field; adductor impressions scarcely recognizable, restricted to posterior part of muscle field. Adductor impressions elongate, situated just anterior of delthyrial cavity. Muscle field divided medially by anteriorly bladelike septum with triangular cross section posteriorly. Median septum extends anteriorly to about midlength, muscle field about half as wide as maximum width. Hollow spine bases originate at base of palintrope, extend medially until reaching exterior where they diverge laterally. Region posterolateral to muscle field pustulose. External ornamentation impression present peripherally.

Brachial valve interior.-Cardinal process lobes, striate both posteriorly and medially, bounded posteriorly by chilidial plates, anteriorly fused with buttress plates. Muscle impressions consist of two pairs of adductors, one posterolateral and other anteromedial in position, separated from each other by low, trifid, platform of secondary material. Dental sockets not crenulated, laterally directed, bounded by interarea and short socket ridges. Costellae impressed on interior, become more pronounced peripherally. Muscle field restricted to posterior quarter of valve.

Measurements.-Relation between length and width of pedicle valves is linear with a relatively low degree of dispersion (fig. 10).

Comparison.-C. dawsoni may be junior synonym of $C$. complanata but adequate material of former is not available for comparison. Adequate comparative material of other species of Chonostrophiella is not available.

Occurrence.-USGS locs. 2718-SD, 2720-SD, 


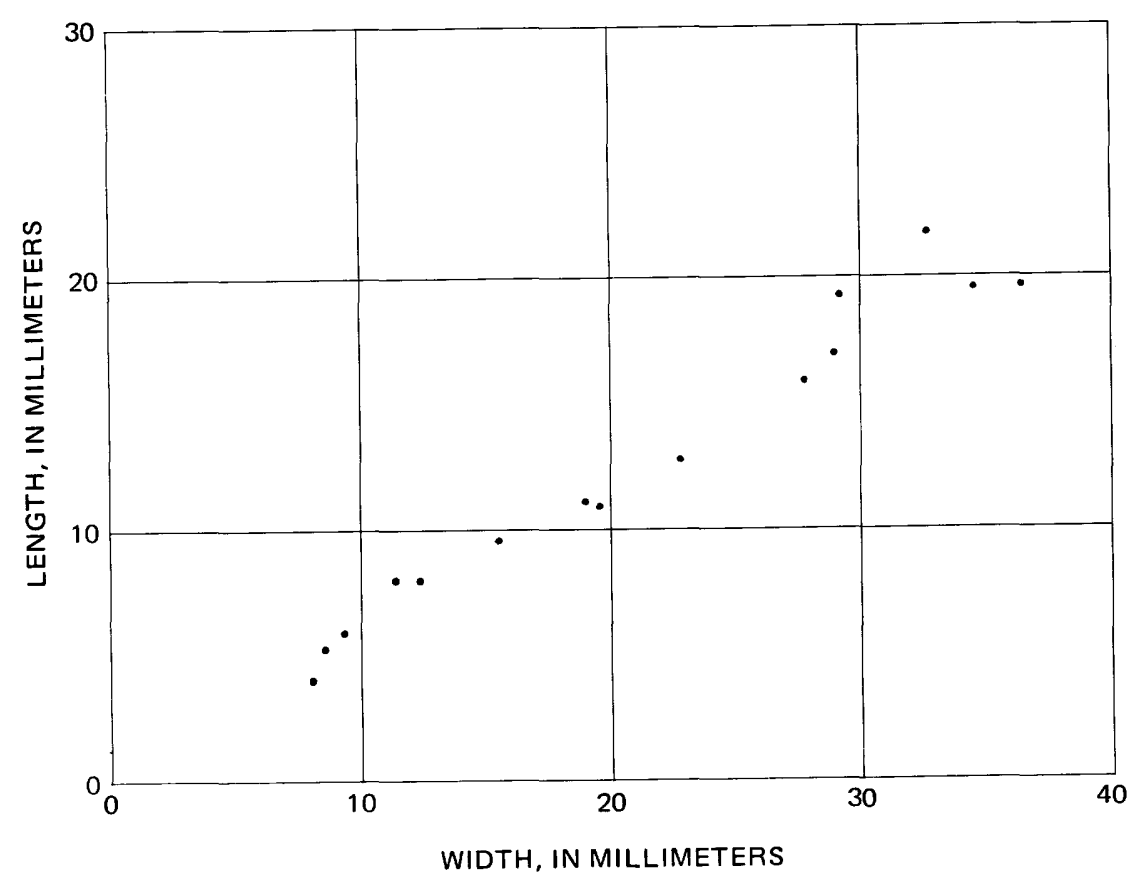

Figure 10.-Comparison of length versus width of pedicle valves of Chonostrophiella complanata (Hall, 1857). Lower sandstone of Tarratine Formation, USGS loc. 2718-SD, Long Pond quadrangle, Somerset County, Maine.

2767-SD, 2719-SD, 2691-SD, 2721-SD, 2722-SD, 3090-SD, 2796-SD, 2727-SD, 2777-SD, 2766-SD, 3088-SD, 2824-SD, 2862-SD, 3482-SD, 2783-SD, 2861-SD, 2890-SD, Somerset and Piscataquis Counties, Maine.

Stratigraphic location.-Seboomook Formation (Lower Devonian), and upper and lower sandstones of the Tarratine Formation (Lower Devonian).

Distribution.-Eastern North America.

Figured specimens.-USNM 126254, 126237, 126240, 126241, 126236, 126225, 126243, 126242.

\footnotetext{
Suborder RHYNCHONELLOIDEA

Superfamily RHYNCHONELLACEA

Family TRIGONIRHYNCHIIDAE

Genus CUPULAROSTRUM Sartenaer, 1961

Cupularostrum macrocosta Boucot, n. sp.

Plate 12, figures 3-11
}

Exterior.-Unequally biconvex shells with brachial valve having greater convexity. Cardinal margin terebratulid, pedicle foramen submesothyrid in position. Hinge line very short, curved in anterolateral direction. Deltidial plates conjunct. Anterior commissure uniplicate, strongly crenulate. Pedicle valve beak straight. Moderately sized ribs with four to five in sulcus of pedicle valve, seven to nine on either flank. Brachial valve bears eight to ten ribs either side of median line. Shell outline pentagonal to subcircular with greatest width at about mid- length. Lateral margins rounded, anterior margin greatly rounded. Shells large, many reaching length of $3 \mathrm{~cm}$.

Pedicle valve interior.-Dental lamellae short, support short, bladelike, laterally directed hinge teeth. Muscle field impression barely discernible except in large specimens. Paired diductor scars enclose median, diamond-shaped adductor scar which narrows anteriorly at about one-third distance to anterior margin. Well-developed pedicle callist located at rear of delthyrial cavity. Muscle area no more than onethird of maximum width, commonly somewhat less. Interior strongly plicated by impress of external ornamentation.

Brachial valve interior.-Discrete hinge plates slightly overlap lateral sides of small septalium, latter supported by median septum which extends anteriorly about one-half length of valve. Laterally directed dental sockets crenulated by about seven to ten ridges distinctly impressed on anterior and bottom of sockets. Muscle field not distinctly impressed. Interior strongly plicated by impress of external ornamentation.

Comparison.-Externally C. macrocosta resembles Billings' (1874) "Rhynchonella" excellens and " $R . "$ dryope, both from Gaspé limestone No. 3. "R." $d r y$ ope has only three costae in sulcus, whereas " $R . "$ excellens has much finer costae than $C$. macrocosta. 
C. macrocosta reaches much larger size than the type species $C$. recticostatum Sartenaer, 1961, which only has three and sometimes four costae in sulcus.

Discussion.-Hall and Clarke's (1894) definition of this genus (as Camarotoechia) makes necessary a complete acquaintance with the structure of cardinalia before a species can be generically assigned. External form and ornamentation are not diagnostic; true Cupularostrum has septalium commonly roofed over by a perforate hinge plate, also crenulate dental sockets.

Occurrence.-USGS locs. 2750-SD, 2814-SD, 2852-SD, 2820-SD, 2840-SD, 2842-SD, Brassua Lake quadrangle, Somerset County, Maine.

Stratigraphic location.-Tomhegan Formation (Lower Devonian).

Holotype.-USNM 125851.

Figured specimens.-USNM 125852, 125855, $125857,125904$.

\section{Cupularostrum? sp.}

Plate 12, figures 12-21

Exterior.-Unequally biconvex shells, brachial valve having greater convexity. Shell outline subcircular, greatest width near midlength. Cardinal margins terebratulid, beak suberect. Hinge line very short, curved in anterolateral direction. Anterior commissure uniplicate, crenulate. Brachial valve bears well-developed fold, pedicle valve has corresponding sulcus. Costae, about three in sulcus, four on fold, five on each flank.

Brachial valve interior.-Serial sections show septalium covered with hinge plate anterior of small apical foramen. Median septum supports septalium. Interior strongly plicated by external ornamentation. Nature of dental sockets not elucidated by serial sections.

Pedicle valve interior.-Small dental lamellae situated either side weakly impressed muscle field which is situated in delthyrial cavity. Interior strongly plicated by impress of external ornamentation.

Occurrence.-USGS loc. 3601-SD, Spencer Lake quadrangle, Somerset County, Maine.

Stratigraphic location.-Beck Pond Limestone (Lower Devonian).

Figured specimens.-USNM 125862, 125859.

Unfigured specimens._USNM 125860.

\section{Genus ANCILLOTOECHIA Havlicek, 1959}

Ancillotoechia sp.

Plate 12, figures 22-26

Discussion.-A few poorly preserved specimens from Maine possess external form and ornamentation of Ancillotoechia. The material is too poor to be specifically assigned. During the study of Early Devonian rhynchonellids from Maine, here assigned to Ancillotoechia, the close similarity of external features of the rhynchonellid species bidentata $\mathrm{Hi}-$ singer, bialveata Hall, and acinum Hall was investigated. Hall $(1863$, p. 215) drew attention to these similarities by comparing the three species. Serial sectioning of Amsden's species Ancillotoechia haraganensis (close to and possibly synonymous with $A$. bialveata (Hall)), "Rhynchonella"' bidentata, and " $R$." acinus shows that haraganensis belongs to Ancillotoechia (fig. 11) ; that bidentata belongs to an undescribed homeomorphic genus (fig. 13); and that acinus belongs to Diabolirhynchia Drot, 1964 (fig. 12).

Occurence.-USGS loc. 3499-SD, Spencer Lake quadrangle, Somerset County, Maine.

Stratigraphic location.-Beck Pond Limestone (Lower Devonian).

Figured specimen.-USNM 125902.

Unfigured specimen.-USNM 125901.

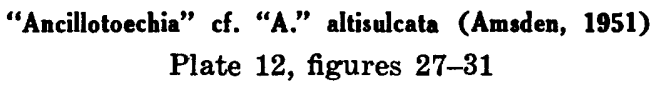

Exterior.-Unequally biconvex shells having gently convex pedicle valve, subpyramidal brachial valve. Brachial valve highly convex, made subpyramidal by fold which extends upwards from rest of valve, near midlength, at angle of about $30^{\circ}$. Pedicle valve has broad, low sulcus and very high tongue

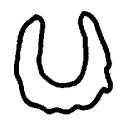

13.4

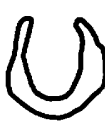

13.3

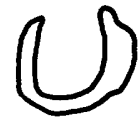

13.3

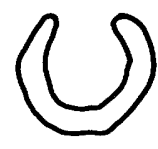

13.1

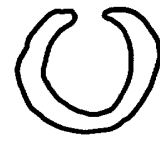

13.0

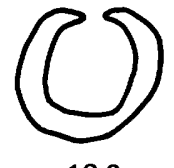

13.0

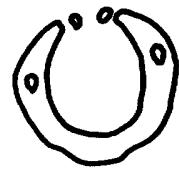

13.0

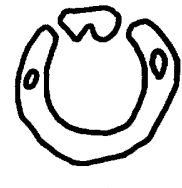

12.95

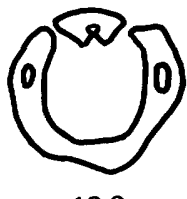

12.9
FigurE 11.-Serial sections of three specimens of Ancillotoechia haraganensis (Amsden) USNM 125858, $\times$ 4.5. Haragan Shale, White Mound, 3 miles west of Nebo, Okla. Numbers are measurements in millimeters from posterior end of shell. 


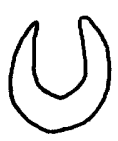

10.65

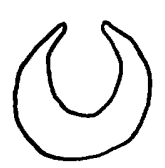

10.4

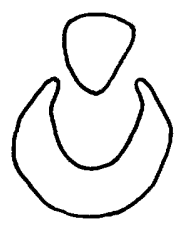

10.2

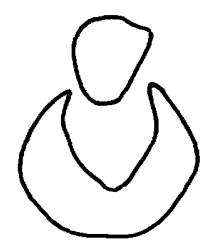

10.15

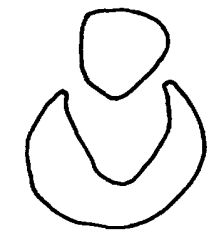

10.1

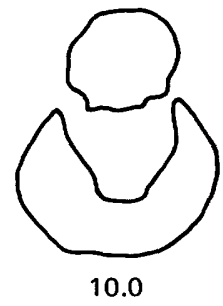

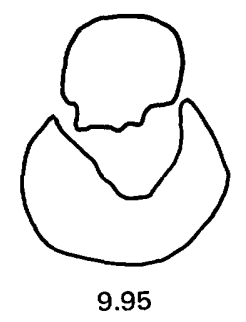
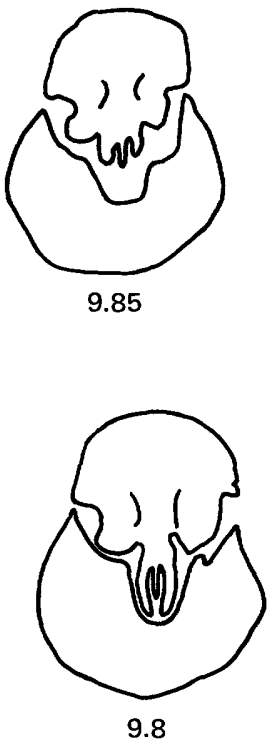
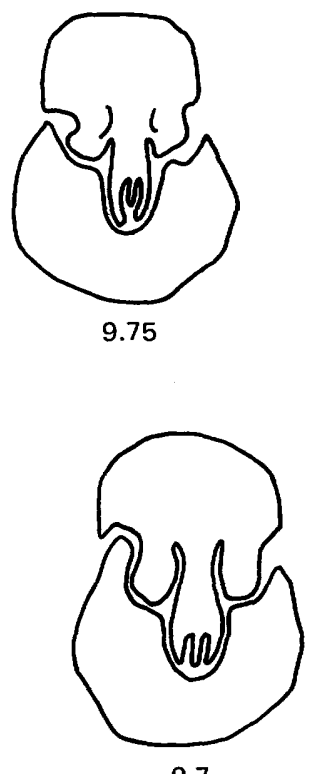

9.7

FIgURE 12.-Serial sections of Diabolirhynchia acinus (Hall, 1863), $\times$ 4.5, USNM 126049. Waldron Shale, Waldron, Indiana. Numbers are measurements in millimeters from posterior end of shell.

anteriorly corresponding to high fold in brachial valve. Shells pentagonal in outline, greatest width near midlength. Lateral margins rounded into very gently rounded anterior margin. Anterior margin uniplicate, strongly crenulate. Pedicle valve beak incurved, terebratulid. Fold bears about four angular costae, sulcus contains about three. Each flank bears about seven costae. Neither fold nor sulcus developed in umbonal regions of shell. Concentric growth lines present on valves.

Pedicle valve interior.-Serial sections (fig. 14) show valve possesses short dental lamellae bordering delthyrial cavity and muscle fields poorly impressed.

Brachial valve interior.-Septalium formed by median septum that bifurcates into laterally diverging branches posteriorly. Borders of septalium overlapped by discrete hinge plates. Dental sockets roofed over posteriorly by outer edges of hinge plates. Muscle field poorly impressed.

Occurrence.-USGS loc. 3488-SD, Spencer Lake quadrangle, Somerset County, Maine.
Stratigraphic location.-Hardwood Mountain Formation (Upper Silurian).

Figured specimens.-USNM 125854.

Family UNCINULIDAE

Genus SPHAERIRHYNCHIA Cooper and Muir-Wood, 1951

Sphaerirhynchia sp. 1

Plate 12, figures 32-36; plate 13, figures 26-28

Exterior.-Unequally biconvex shells with brachial valve about twice convexity of pedicle valve. Shell outline subcircular to longitudinally elliptical. Anterior and lateral margins rounded, greatest width near midlength. Brachial valve bears broad, low fold, pedicle valve corresponding sulcus. Pedicle valve has long tongue anteriorly which extends up to join fold on brachial valve. Anterior margin uniplicate, crenulate. Cardinal margin terebratulid in form, beak of pedicle valve appears incurved. Small, rounded costae, about ten costae in fold and sulcus, about ten costae each flank.

Pedicle valve interior.-Short dental lamellae located either side of delthyrial cavity. Serial sections indicate muscle field not very deeply impressed. 


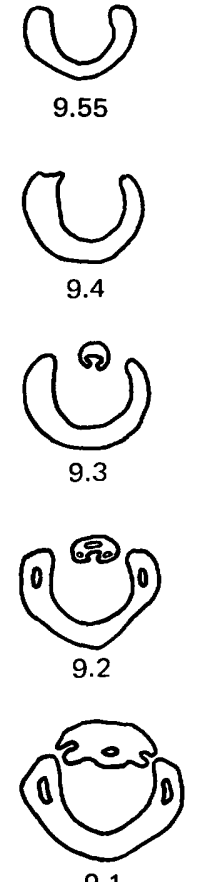

9.1
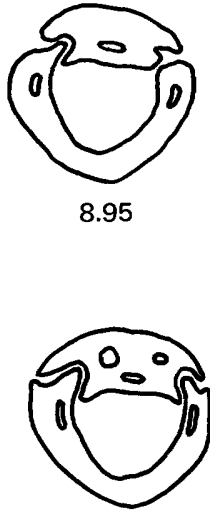

8.9

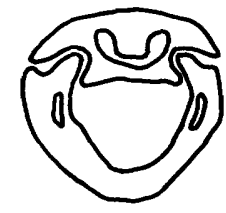

8.8
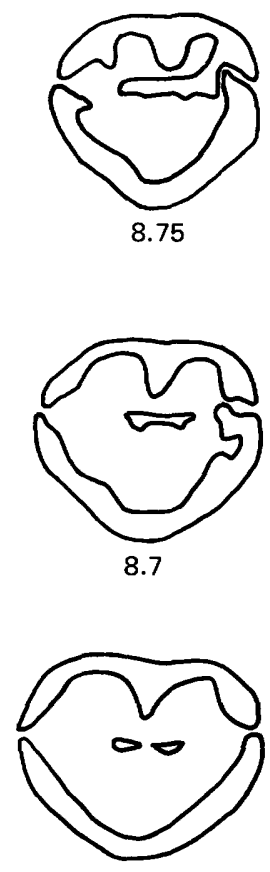

8.6

Figure 13.-Serial sections of "Rhynchonella" bidentata (Hisinger, 1826), $\times$ 4.5, USNM 125880. Silurian beds near Klinteham, Gotland, Sweden. Numbers are measurements in millimeters from posterior end of beak.

Brachial valve interior.-Septalium supported by median septum. Discrete hinge plates project over medial edge of cruralium. Lateral edges of hinge plates project over medial edge of dental sockets.

Comparison.-Maine material is too scanty for specific identification.

Occurrence.-USGS loc. 3470-SD, 3469-SD, Spencer Lake quadrangle, locality 5586-SD, Attean quadrangle, Somerset County, Maine.

Stratigraphic location.-Hardwood Mountain Formation (Upper Silurian).

Figured specimens._USNM 125874, 160127160129.

Unfigured specimens.-USNM 125875, 126385.

Sphaerirhynchia sp. 2

Plate 13, figures 1-6

Exterior.-Unequally biconvex shells with brachial valve having greater degree convexity. Shell outline longitudinally elliptical, maximum width located about two-thirds the distance to anterior margin. Beaks attenuated, pedicle valve incurved. Pedicle valve cardinal margin terebratulid in form. Brachial valve bears low fold, pedicle valve corresponding sulcus. Anterior commissure uniplicate, crenulate. Relatively coarse, rounded costae, two on fold in small specimens to six in large specimens.
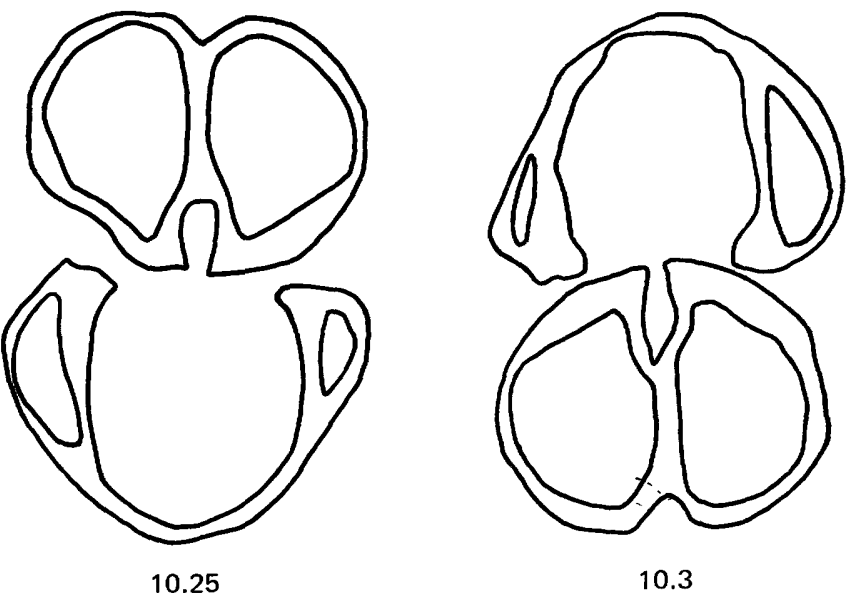

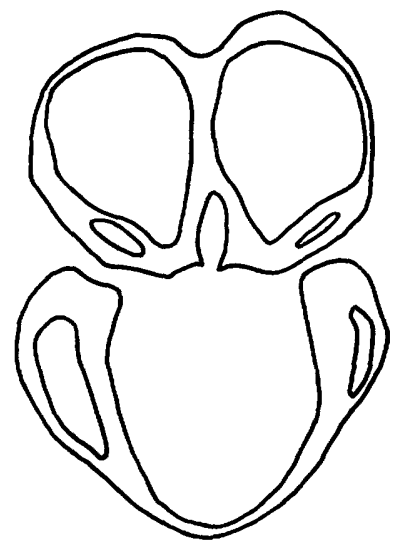

10.2

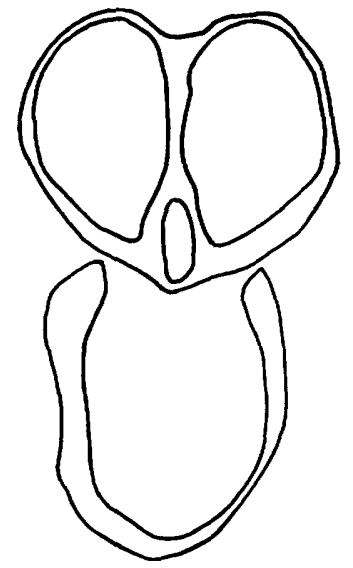

10.7

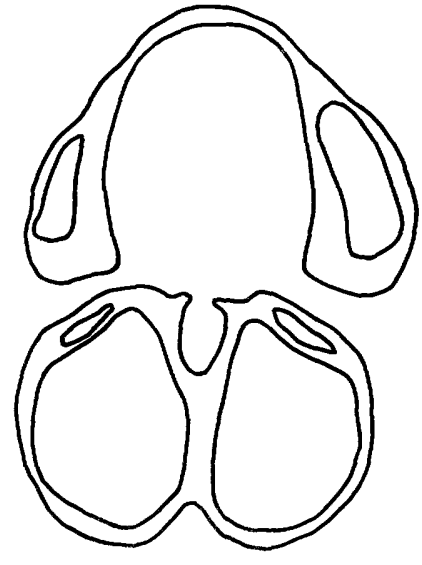

10.15

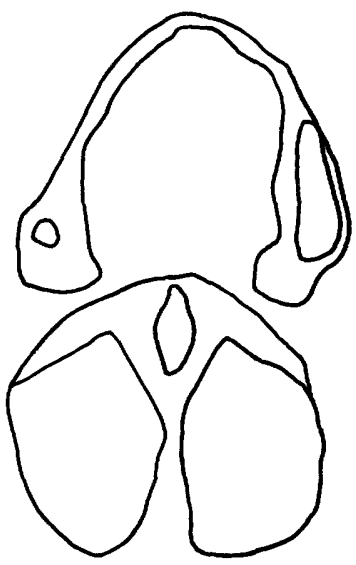

10.5
FIGURE 14.-Serial sections of "Ancillotoechia" cf. " $A$." altisulcata (Amsden, 1951), parallel to hinge line distance from beak given in millimeters; $\times$ 4.5. Hardwood Mountain Formation, USGS loc. 3488-SD, Spencer Lake quadrangle, Somerset County, Maine. 
Sulcus of small specimens contains one costa, flanks bear from six to eight costae each. Lateral and anterior margins rounded. Radial ornamentation crossed by concentric growth lines.

Pedicle valve.-Serial sections of pedicle valve show presence of short dental lamellae bounding delthyrial cavity. They are partly obsolete due to deposition of secondary material in umbonal cavities. Muscle field very deeply impressed into secondary material deposited in posterior portion of shell.

Brachial valve interior.-Posteriorly located, small septalium supported by long median septum extends to about midlength. Interior of valve strongly plicated by impress of costae except in umbonal region.

Comparison. $-S$. sp. 2 has much coarser costae than $S$. sp. 1 and resembles $S$. sp. 3 in this regard. $S$. sp. 2 has a more deeply impressed pedicle valve muscle field than $S$. sp. 3. Not enough material of any of these forms is available for sound specific identification.

Occurrence.-USGS loc. 3499-SD, Spencer Lake quadrangle, Somerset County, Maine.

Stratigraphic location.-Beck Pond Limestone (Lower Devonian).

Figured specimens.-USNM 125877, 125876.

Unfigured specimens.-USNM 125878, 125879, 126389.

Sphaerirhynchia sp. 3

Plate 13, figures 7-12

Exterior.-Unequally biconvex shells, brachial valve having about one and one-half times convexity of pedicle valve. Valve outline subcircular, greatest width near midlength. Anterior and lateral margins rounded. Brachial valve bears low, broad fold, pedicle valve corresponding sulcus. Pedicle valve beak incurved, cardinal margins terebratulid in form. Anterior commissure uniplicate, crenulate. Low, rounded costae with about six on fold, five in sulcus, about ten to twelve each flank.

Pedicle valve interior.-Dental lamellae very short, almost entirely obsolete due to deposition of secondary material in umbonal cavities. Muscle field extends about one-third distance to anterior margin, very elongate in form. Well-developed pedicle callist located at posterior of delthyrial cavity. Anterior of pedicle callist a pair of very narrow anterolaterally striated diductor impressions. Lateral to medial diductor impression pair roughened, elongate impressions which may have served as site for pair of lateral diductors. Peripherial parts of valve plicated by impress of external ornamentation.

Brachial valve interior.-Serial sections, show septalium supported by long median septum.
Occurrence.-USGS loc. 3601-SD, Spencer Lake quadrangle, Somerset County, Maine.

Stratigraphic location.-Beck Pond Limestone (Lower Devonian).

Figured specimens.-USNM 125870, 125871.

Sphaerirhynchia? sp.

Plate 13, figures 13-18

Exterior.-Unequally biconvex shells, brachial valve about twice convexity of pedicle valve. Specimen outline transversely elliptical although so deformed that it is difficult to be sure of original form. Maximum width located near midlength. Pedicle valve bears low, broad fold, pedicle valve corresponding sulcus. Lateral and anterior margins rounded. Anterior commissure uniplicate, crenulate. Fold bears about four to five low, rounded costae, sulcus contains about three to four costae. Costae in tongue of pedicle valve medially grooved. Each flank bears about 17 costae.

Pedicle valve interior.-Dental lamellae very short, obsolete due to deposition of secondary material in umbonal cavities. Pedicle callist deeply impressed, occupies posterior part delthyrial cavity. Diductor impressions deeply impressed, abut anterior face pedicle callist. Diductors very narrow, medially separated by low myophragm, extend anteriorly about one-third length of valve. Impression of costae noticeable in peripheral region of valve, absent posteromedially where overlain by secondary material.

Brachial valve interior.-Small, posteriorly located septalium supported by median septum that extends anteriorly about one-third length of valve. Septalium part roofed over by conjunct hinge plates as in Cupularostrum. Dental sockets medially roofed over by projecting edges of hinge plates. Species is similar to Sphaerirhynchia except as regards conjunct hinge plates; form very unlike Cupularostrum which does not approach almost globular shape of these shells.

Occurrence.-USGS loc. 3488-SD, Spencer Lake quadrangle, Somerset County, Maine.

Stratigraphic location.-Hardwood Mountain Formation (Upper Silurian).

Figured specimens.-USNM 127385A, B.

\section{Family UNCERTAIN \\ Genus SULCATINA Schmidt, 1964 \\ Sulcatina sp.}

Plate 13, figures $19-25$

Exterior.-Unequally biconvex shells with brachial valve about $11 / 2$ times convexity of pedicle valve. Greatest width about three-quarters of distance to anterior margin. Shell outline transversely elliptical. 
Pedicle valve beak strongly incurved, margin terebratulid in form. Lateral margins strongly rounded, anterior margin gently rounded. Brachial valve has pronounced broad fold which bears about five to six rounded costae. Pedicle valve has corresponding sulcus which commonly contains about four or five castae. Flanks each bear about nine to eleven costae. Anterior commissure uniplicate, crenulate. On specimens studied costae broaden anteriorly, not observed to bifurcate or increase by implantation. Hinge line very short, curved in anterolateral direction. Brachial valve beak completely concealed beneath incurved pedicle valve beak.

Pedicle valve interior.-Dental lamellae very short, almost entirely obsolete in large specimens owing to deposition of secondary material in umbonal cavities. They support stout, plate-like hinge teeth which project beyond relatively short hinge line. Crural fossettes relatively narrow, laterally directed, bordered by hinge line and hinge teeth. Muscle field deeply impressed, consists of subcircular diductor impression, medially divided by low myophragm, which anteriorly and laterally surrounds small, posteriorly located, elongate adductor impressions. Behind myophragm, anterior or prominent pedicle callist which occupies posterior wall and base of delthyrial cavity, are two pairs of elongate adjustor impressions. Area lateral to muscle field somewhat roughened by deposits of secondary material, and muscle field itself surrounded by low ridge secondary material which begins at base of dental lamellae and continues in anterior and then anteromedial direction before becoming very faint in front of myophragm.

Brachial valve interior.-Bifid cardinal process whose lobes curve to form scoop-shaped structure. Anterior part of structure nearly vertical but posteriorly swing medially and become inclined before joining near midline. Lateral faces of lobes have steps which parallel bottom of elongate, anterolaterally directed dental sockets which are roofed medially by projecting cardinal process lobes. Notothyrial cavity, between cardinal process lobes, has secondary material laid down anteriorly forming lozenge-shaped outline. Anterior of notothyrial cavity is low, sharp myophragm or ridge which extends about one-half length of valve. On either side of cardinalia and slightly anterior are deeply impressed, subcircular impressions of posterior adductor scars. Anterior of posterior adductor scars are elongate, paired anterior adductor impressions which extend to about midlength.

Comparison.-S. sulcata (Cooper, 1942) has more costae on the fold and sulcus than does the material from Maine. S. tennesseensis (Foerste) has about the same number of costae but is more subcircular in outline than the Maine material; as Tennessee specimens are smaller; they may be an earlier growth stage of the Maine material. Adequate comparative specimens are not available to specifically identify the Maine material.

Occurrence.-USGS loc. 3488-SD, Spencer Lake quadrangle, Somerset County, Maine.

Stratigraphic location.-Hardwood Mountain Formation (Upper Silurian).

Figured specimens.-USNM 125850, 125853A, $125847,125848$.

Unfigured specimens._USNM 125849, 126388.

\section{Family EATONIIDAE \\ Genus COSTELLIROSTRA Cooper, 1942 \\ Costellirostra sp. \\ Plate 14, figures 1-5}

Exterior.-Unequally biconvex shells with brachial valve having greatest convexity. Brachial valve develops relatively narrow fold anterior of midlength. Fold rises abruptly at angle of about $30^{\circ}$ from rapidly descending anterior part of valve. Pedicle valve bears relatively shallow sulcus corresponding to fold, anterior part of pedicle valve prolonged into a tongue. Specimen outline subtriangular due to attenuated beak. Greatest width slightly anterior of midlength. Lateral and anterior margins rounded. Pedicle valve beak incurved, cardinal margins terebratulid in form. Relatively low, fine striae barely visible on Maine material.

Pedicle valve interior.-Imperfectly preserved pedicle valve interior shows pair deeply impressed adductor impressions, small in size, sunk into pit near anterior part of muscle field.

Brachial valve interior.-Median septum extends to about midlength on Maine material, nature of cardinalia not established.

Comparison.-External form and ornamentation, coupled with the nature of the muscle field in the pedicle valve, justify assignment to Costellirostra, but specific identification is not possible.

Occurrence.-USGS loc. 2806-SD, Pierce Pond quadrangle, Somerset County, Maine.

Stratigraphic location.-McKenney Ponds Member of the Tarratine Formation (Lower Devonian).

Figured specimen.-USNM 125885.

Unfigured specimens.-USNM 125884, 125886.

Genus EATONIA Hall, 1857

Eatonia cf. E. medialis (Vanuxem, 1842)

Plate 14, figures 6-13

Exterior.-Unequally biconvex shells with brachial valve very inflated, pedicle valve gently convex. 
Brachial valve bears prominent fold which originates just anterior of umbo and rises at angle of about $30^{\circ}$ from descending anterior part of valve. Shell outline transversely elliptical, greatest width near midlength. Pedicle valve beak incurved, hinge line curved anterolaterally. Rounded costae, four on fold, three in sulcus, and six on each flank. Lateral margins rounded, but anterior margin almost straight. Anterior part of sulcus projects up as prominent tongue to engage fold of brachial valve. Anterior commisure uniplicate, crenulate.

Pedicle valve interior.-Dental lamellae not abserved on Maine specimens, but deeply impressed muscle field present. Muscle field consists of paired diductor impressions, surrounded by narrow ridge of secondary material which originates near sides of delthyrial cavity, enclosing pair of small, elongate, medially divided adductor impressions sunk below level of diductor impressions. Low narrow median septum traverses muscle field, reaches to about midlength. Impression of external costae marked in peripheral regions of valve.

Brachial valve interior.-Massive, terminally bifid, posteriorly located cardinal process supported by long narrow median septum which reaches almost to midlength. Brachiophores appear to be slender and diverge anterolaterally from base of cardinal process. Muscle field divided by median septum and consists of two pairs adductor impressions, posterior pair small and subcircular in outline, anterior pair elongate and extending to about midlength. Muscle impressions separated by low rounded ridge of secondary material about normal to median septum.

Comparison.-Maine specimens resemble $E$. medialis, but their poor state of preservation precludes specific identification.

Occurrence.-USGS loc. 3499-SD, Spencer Lake quadrangle, Somerset County, Maine.

Stratigraphic location.-Beck Pond Limestone (Lower Devonian).

Figured specimens.-USNM 125872, 125873, $125882 \mathrm{~B}$.

\section{Unfigured specimens._USNM 126387.}

Eatonia? sp.

Discussion.-A few poorly preserved specimens from Parker Bog Formation have prominent fold and sulcus with Eatonia type costae. Nothing is known of the interior of this material; exterior is so poorly preserved that assignment to Eatonia can only be speculative.

Occurrence.-USGS loc. 3477-SD, Pierce Pond quadrangle, Somerset County, Maine.
Stratigraphic location.-Parker Bog Formation (Lower Devonian).

Unfigured specimens.-USNM 126388.

\section{Family RHYNCHOTREMATIDAE Genus MACHAERARIA Cooper, 1955 \\ Machaeraria mainensis Boucot, n. ap. \\ Plate 14, figures 14-21}

Exterior.-Unequally biconvex shells with brachial valve having about $11 / 2$ times convexity of pedicle valve. Shell outline transversely elliptical with greatest width near midlength. Brachial valve bears relatively broad low fold which originates near umbo; pedicle valve has corresponding sulcus. Pedicle valve beak slightly incurved, hides beak of brachial valve. Cardinal margins subterebratulid. Pedicle valve foramen submegathyrid, deltidial plates appear to be apically conjunct. Lateral and anterior margins rounded. Pedicle valve sulcus prolonged into tongue which fits against fold of brachial valve. Angular costellae about four on fold, three in sulcus, about eight each flank. Anterior commissure uniplicate, crenulate.

Pedicle valve interior.-Short dental lamellae support relatively stubby hinge teeth. Dental lamellae almost obsolete due to deposition of secondary material in umbonal cavities. Muscle field well impressed, consists of elongate diductor impression medially divided by low myophragm and surrounding a pit which contains small, elongate adductor impressions. Periphery crenulated by impression of external costellae, but remainder of interior relatively smooth due to deposition of secondary material.

Brachial valve interior.-Linear cardinal process anteriorly joined by low, rounded myophragm or ridge which extends to about midlength of valve. Laterally flanking cardinal process are relatively stubby hinge plates supported by crural plates. Nature of brachiophores not determined on Maine material. Muscle field quadripartite, consists of pair medial adductor impressions which are elongate in outline and extend to about midlength from just anterior of cardinalia. Lateral pair adductor impressions subtriangular in outline, located just anterior of crural plates. Dental sockets relatively shallow, laterally directed. Base each crural plate medially directed to meet myophragm, and form sessile cruralium.

Comparison.-M. mainensis lacks flaring margins of sulcus as developed in Early Devonian type species $M$. formosa.

Occurrence.-USGS locs. 3479-SD, 2712-SD, Spencer Lake quadrangle, Somerset County, Maine. 
Stratigraphic location.-Base of Hobbstown Formation (Upper Silurian).

Holotype.-USNM 125869.

Figured specimens.-USNM 125867A, 125868, $125869 \mathrm{~A}$.

Unfigured specimens.-USNM 126376, 126377.

Suborder ATRYPOIDEA
Superfamily ATRYPACEA
Family ATRYPIDAE
Subfamily ATRYPINAE
Genus ATRYPA Dalman, 1828

Atrypa cf. A. tennesseensis Amsden, 1949

Plate 14, figures 22-27

Exterior.-Subsequently biconvex shells, brachial valve slightly more convex than pedicle valve. Valve outline variably transverse to elongate, but deformation may have partly determined outline because most specimens are more or less crushed. Straight hinge line, shorter than greatest width near midlength. Anterior commissure rectimarginate, crenulate. Cardinal margin submegathyrid, delthyrium appears unmodified. Pedicle valve beak probably incurved over that of brachial valve. Radially disposed costae crossed by very prominent concentric lamellae, free at anterior ends as frills. Brachial valve bears about four unbranched costae on each side of median costa while pedicle valve bears five unbranched costae each side of midline. No specimen exceeds about $1 \mathrm{~cm}$ length. Lateral and anterior margins rounded.

Pedicle valve interior.-Very short dental lamellae on either side of delthyrial cavity support stout hinge teeth which project vertically and have subcircular cross section. Muscle field poorly impressed, appears flabellate, extends anteriorly to near midlength, about half as wide as valve.

Posteriorly located, elongate pair of adductor impressions anteriorly and laterally surrounded by flabellate diductor impressions. Costae impression marked on interior of valve except in posteromedial parts.

Brachial valve interior.-Pair of discrete hinge plates diverge laterally from midline and form anterior socket walls. Crenulations barely discernible in bottom of dental sockets. Low myophragm extends anteriorly from notothyrial cavity to position one-third of distance from posterior margin. Muscle field very weakly impressed. Costae impression marked except in posteromedial parts of valve.

Comparison.-Maine specimens resemble small specimens of Atrypa tennesseensis in external form and ornamentation. Secondary costae are not present except in anteriormost parts of the Maine specimens, whereas in larger specimens from Oklahoma (Amsden, 1951, pl. 17, fig. 33) numerous, well-defined costae originate by bifurcation in peripheral regions of shell. Amsden's figure 32 is a specimen with anomalous ornamentation consisting of costae which are much stronger and bifurcate near umbo and may not belong to $A$. tennesseensis.

Occurrence.-USGS loc. 3479-SD, Spencer Lake quadrangle, Somerset County, Maine.

Stratigraphic location.-Base of Hobbstown Formation (Upper Silurian).

Figured specimens.-USNM 126002-126004.

Unfigured specimens.-USNM 126396-126401.

\section{Atrypa cf. A. arctostriata Foerste, 1903}

Plate 14, figures 28-29

Exterior.-Subequally biconvex shells with brachial valve having somewhat greater degree of convexity than pedicle valve. Shell outline subcircular, greatest width near midlength. Anterior commissure rectimarginate, crenulate. Lateral and anterior margins rounded. Frill of spines surrounds periphery, costellae increase by bifurcation and are crossed by concentric lamellae having free frills.

Pedicle valve interior.-Only one fragmentary pedicle valve is available, but it indicates that in small shells the muscle field is weakly impressed, flabellate in form, posteriorly bounded by short dental lamellae.

Brachial valve interior.-Discrete hinge plates anteriorly bound dental sockets. Hinge plates and dental sockets anterolaterally directed. Short myophragm medially divides weakly impressed, posterior, elongate adductor impressions, posteriorly stops at undivided notothyrial cavity, which is probably the site for diductor attachment. Dental sockets very feebly crenulated basally. Anterior of posterior pair of adductor impressions is peripheral impress of external ornamentation.

Comparison.-The Maine material is of the same external form and ornamentation as Atrypa arctostriata, but is too poorly preserved to be specifically assigned without doubt.

Occurrence.-USGS loc. 3479-SD, Spencer Lake quadrangle, Somerset County, Maine.

Stratigraphic location.-Base of Hobbstown Formation (Upper Silurian).

Figured specimens._USNM 126014A, 126015B.

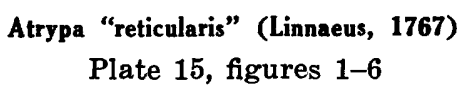

Atrypa "reticularis" (Linnaeus, 1767), see Boucot, 1959b, p. 741-742, pl. 91, figs. 7-9.

Exterior.-Unequally biconvex shells, brachial valve about twice convexity of pedicle valve. Hinge line about two-thirds as wide as maximum width, which is at about one-third of distance to anterior 
margin. Cardinal margins submegathyrid. Delthyrium open, apparently unmodified. Pedicle valve weakly sulcate. Anterior commissure weakly uniplicate, crenulate. Shells longitudinally elongate to subcircular with rounded anterior and lateral margins. Costellae increase by bifurcation, crossed by concentric growth lines. Pedicle valve beak straight to gently incurved.

Pedicle valve interior.-Stout, bladelike hinge teeth project anteromedially from rear of valve, supported by short dental lamellae which are almost entirely obsolete due to deposition of secondary material in umbonal cavities. Muscle impressions large, flabellate, extends to about midlength, about twothirds as wide as valve. Muscle impressions elliptical pair small, posteriorly located adductor impressions laterally and anteriorly surrounded by deeply impressed diductor field. Diductor field radially divided into number of sectors by short myophragms which begin near anterior margins of delthyrial cavity. Deeply impressed horizontally striate pedicle callist located on posterior wall delthyrial cavity. Crural fossettes relatively deep, restricted to area lateral of hinge teeth. Valve periphery crenulated by impress of external ornamentation. Areas lateral to muscle impressions deeply pitted.

Comparison.-Above description is based on specimens from the Tomhegan Formation which resemble A. reticularis $\mathrm{s}$. 1 . in character of external form and ornamentation. Additional specimens of Atrypa cf. $A$. reticularis, in a poor state of preservation, have been obtained from other units. Some from the Hardwood Mountain Formation are covered with spines and have a peripheral frill of spines.

Occurrence.-USGS locs. 3485-SD. 3150-SD, 3475-SD, 3496-SD, 3469-SD, 3499-SD, 2820-SD, 2750-SD, 3488-SD, 2761-SD, 2840-SD, 2730-SD, Somerset and Piscataquis Counties, Maine.

Stratigraphic location.-Tomhegan Formation (Lower Devonian), Seboomook Formation (Lower Devonian), Beck Pond Limestone (Lower Devonian), Hardwood Mountain Formation (Upper Silurian), hornfels on Limestone Hill (Lower Silurian), undifferentiated Silurian beds on Deer Island.

Figured specimens.-USNM 126008, 126010, $126011,126068$.

Unfigured specimens.-USNM 126390-126395.

Family LISSATRYPIDAE

Genus LISSATRYPA Twenhofel, 1914 Lissatrypa sp.

Plate 15, figures 7-16

Exterior-Unequally biconvex shells, pedicle valve about $11 / 2$ times convex as relatively gently convex brachial valve. Valve outline subcircular, greatest width slightly posterior of midlength. Lateral and anterior margins evenly rounded. Anterior commissure rectimarginate. Pedicle valve delthyrium open, unmodified. Hinge line narrow, about one fifth as wide as greatest width of shell. Cardinal margins terebratulid. Pedicle valve beak suberect, tends to conceal brachial valve. Concentric growth lines.

Pedicle valve interior.-Stout hinge teeth occur either side delthyrial cavity, laterally bound slightly raised pedicle callist on posterior wall delthyrial cavity. Muscle field deeply impressed, consists of narrow, median adductor impression on raised track and laterally bounded by elongate diductor impressions which extend to midlength and are medially bounded by anterolaterally trending, divergent ridges which originate at base of median adductor track. Valve interior smooth.

Brachial valve interior.-Discrete, bulbous hinge plates medially join low, broad median septum which is triangular in cross section posteriorly and linear anteriorly. Muscle field two pairs elongate, posteriorly situated adductor impressions. Muscle field extends about one-third distance to anterior margin and is subcircular in outline. Spires atrypoid in nature, about three loops to each spire.

Comparison.-The material is too poorly preserved to be specifically identified. The absence of a sulcus clearly indicates this material cannot be assigned to the genus Meifodia.

Occurrence.-USGS locs. 3488-SD, 3473-SD, Spencer Lake quadrangle, locality 4843-SD, Attean quadrangle, Somerset County, Maine.

Stratigraphic location.-Hardwood Mountain Formation (Upper Silurian).

Figured specimens.-USNM 125905A,B, 126000, 125908A,B, 160130A,B.

Unfigured specimens.-USNM 125906, 125909, 126013.

\section{Genus NANOSPIRA Amsden, 1951 \\ Nanospira? sp. \\ Plate 15, figure 16}

Exterior.-Brachial valve convex, bears prominent, broad sulcus originating near umbo. Maximum width located slightly anterior of curved hinge line. Lateral and anterior margins rounded. Anterior commissure sulcate. Exterior smooth except for concentric growth lines.

Brachial valve interïor.-Pair of laterally directed hinge plates separated by median trough. Interior smooth.

Comparison.-Single specimen from Maine has external form of Nanospira but not enough evidence is available for generic assignment to be positive. 
Occurrence.-USGS loc. 3479-SD, Spencer Lake quadrangle, Somerset County, Maine.

Stratigraphic location.-Base of Hobbstown Formation (Upper Silurian).

Figured specimen.-USNM 126108A.

\author{
Superfamily DAYIACEA \\ Family LEPTOCOELIIDAE \\ Genus LEPTOCOELIA Hall, 1859 \\ Leptocoelia flabellites (Conrad, 1841) \\ Plate 15, figures 17-24
}

Leptocoelia fabellites (Conrad, 1841), see Boucot, 1959b, p. 741, pl. 91, figs. 1-6.

Exterior.-Unequally convex shells with almost flat brachial valve, convex relatively naviculate pedicle valve. Greatest width near midlength. Lateral and anterior margins evenly rounded. Brachial valve bears low fold, originating near midlength of valve; pedicle valve has corresponding sulcus. Anterior margin uniplicate and strongly crenulate. Delthyrium open and unmodified. Pedicle valve beak suberect and incurved so as to conceal beak of brachial valve. Cardinal margins submegathyrid. Hinge line about two-thirds maximum width. Costae crossed by strong, concentric growth lines. Brachial valve fold bears two costae with four costae on each flank; sulcus of pedicle valve contains one costa with four to five on each flank. Costae increase in width anteriorly, do not bifurcate. Interspaces relatively broad, flat, costae evenly rounded.

Pedicle valve interior.-Stout hinge teeth, having triangular cross section; lie on either side of delthyrial cavity. Anterior face crural fossette crenulated. Apex of triangular cross section of hinge tooth points anteriorly. Rear of delthyrial cavity occupied by pedicle callist located on slightly raised, striated pad of secondary material. Median face of each hinge tooth indented by step which parallels floor of valve and serves to articulate with distal part of brachiophore. Muscle field flabellate in form, reaches anteriorly to about midlength, is from one-third to onehalf maximum width of valve. Muscle field consists of flabellate diductor impression, medially separated by low sharp myophragm which is most pronounced anteriorly. Diductor field encloses deeply impressed, small, elongate, paired adductor impressions which are longitudinally striate and partly roofed over posteriorly by projecting deposit of secondary material. Umbonal region of valve relatively smooth, remainder of valve strongly crenulated by impress of external ornamentation.

Brachial valve interior.-Moundlike, terminally trifid cardinal process anteriorly joined by myophragm. Cardinal process laterally fused with socket plates. Crura bladelike, diverge anterolaterally.
Dental sockets crenulated, roofed over medially by laterally inclined crura, anterolaterally rimmed by ridge of secondary material in large specimens. Myophragm extends to about midlength, narrow, low, and sharp anteriorly, becomes triangular in cross section and more massive posteriorly. Adductor field impression elongate in outline. In large specimens, median ridge of terminally trifid cardinal process rises above lateral ridges which are subdued by deposition of secondary material.

Occurence. - USGS locs. 2691-SD-2705-SD, 2707-SD, 2709-SD-2711-SD, 2717-SD-2722-SD, 2725-SD-2727-SD, 2729-SD, 2731-SD-2735-SD, 2737-SD, 2738-SD, 2740-SD, 2741-SD, 2743-SD, 2745-SD, 2746-SD, 2748-SD, 2749-SD, 2751-SD, 2760-SD, 2761-SD, 2765-SD-2771-SD, 2775-SD, 2776-SD, 2778-SD-2790-SD, 2792-SD-2805-SD, 2807-SD, 2808-SD, 2811-SD-2813-SD, 2819-SD, 2821-SD, 2823-SD, 2824-SD, 2827-SD. 2829-SD, 2830-SD, 2832-SD, 2834-SD, 2837-SD, 2843-SD2849-SD, 2853-SD, 2856-SD-2858-SD, 2860-SD, 2862-SD, 2865-SD, 2870-SD, 2872-SD, 2877-SD, 2879-SD, 2880-SD, 2882-SD, 2883-SD. 2890-SD, 3089-SD-3092-SD, 3094-SD, 3225-SD-3229-SD, 3471-SD, 3474-SD, 3481-SD, 3482-SD. 3486-SD, Somerset County ; 2861-SD, 3088-SD, Piscataquis County, Maine.

Stratigraphic location.-Misery Quartzite Member of the Tarratine Formation (Lower Devonian), upper and lower sandstones of the Tarratine Formation (Lower Devonian), Seboomook Formation (Lower Devonian), questionably in the Kineo Member of the Tomhegan Formation (Lower Devonian).

Distribution.-This species is known from beds of late Helderberg to Schoharie age in eastern North America.

Figured specimens.-USNM 126001, 126005, 125907, 126009, 126012, 127387.

Unfigured specimens.-USNM 126403-126432, $126467,126468,126470,126474-126507$.

\section{Family ANOPLOTHECIDAE \\ Subfamily COELOSPIRINAE \\ Genus COELOSPIRA Hall, 1863 \\ Coelospira sp. \\ Plate 15, figures 25-32}

Discussion.-Deveral localities in Somerset County yielded shells with external ornamentation and internal features of Coelospira, but the material is inadequate for specific determination. Figured Hardwood Mountain specimens are of Silurian rather than Devonian aspect.

Occurrence.-USGS locs. 3499-SD, 3469-SD, 3488-SD, 3483-SD, 3496-SD, 2806-SD, Spencer 
Lake quadrangle, loc. 5995-SD, Attean quadrangle, Somerset County, Maine.

Stratigraphic location.-Hardwood Mountain Formation (Upper Silurian), Beck Pond Limestone (Lower Devonian), and McKenney Ponds Member of Tarratine Formation (Lower Devonian).

Figured specimens.-USNM 126007,A,AA,C, 160131, 160132A,B, 160133.

Unfigured specimens.-USNM 126402.

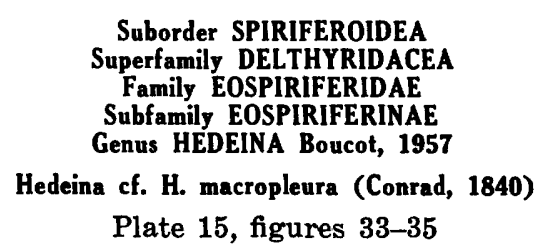

Discussion.-Single brachial valve from Beck Pond Limestone and two fragmentary pedicle valves from McKenney Ponds Member of Tarratine Formation possess characteristic fine ornamentation of eospiriferids and coarse ornamentation characteristic of Hedeina. Specimen from Beck Pond Limestone has cardinalia identical with those of eospiriferids but is too poorly preserved to be specifically assigned without doubt. Material from McKenney Ponds Member certainly belongs to Hedeina as evidenced by broad, flat sulcus and rounded lateral costae, but its specific identity is in doubt. Material from McKenney Ponds Member might have been reworked from preexisting strata of Beck Pond Limestone which were removed by erosion before deposition of the Tarratine Formation.

Occurrence.-USGS locs. 3499-SD, 2810-SD, 2806-SD, Spencer Lake and Pierce Pond quadrangles, Somerset County, Maine.

Stratigraphic location.-Beck Pond Limestone (Lower Devonian) and McKenney Ponds Member of the Tarratine Formation (Lower Devonian) .

Figured specimens.-USNM 126006, 126076.

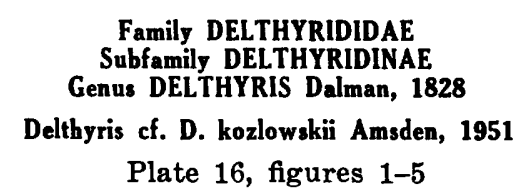

Exterior-Unequally biconvex shells, brachial valve gently convex, pedicle valve subconical. Shell transversely elongate, outline elliptical. Greatest width located at straight hinge line. Brachial valve bears low rounded fold; pedicle valve has corresponding sulcus. Anterior commissure uniplicate, gently crenulate. Lateral margins evenly rounded. Pedicle valve interarea steeply apsacline, slightly concave posteriorly, brachial valve interarea orthocline. Pedicle valve interarea about two-thirds as long as pedicle valve, brachial valve interarea very short. Del- thyrium narrow, including an angle of about $20^{\circ}$. Deltidial plates narrow, located normal to interarea. Not determined if they are apically conjunct. Two or three low rounded plications separated by broad interspaces each flank. Radial striations terminate in fringe of spines on edge of each growth lamella.

Pedicle valve interior.-Median septum extends about three-quarters distance to anterior margin, bisects delthyrial cavity, and is laterally flanked by dental lamellae. Median septum very high posteriorly, slopes steeply in anterior direction. Dental lamellae subparallel, extend anteriorly about onethird length of valve. Nature of hinge teeth undetermined. Impressions of muscle field not discernible. Interior gently crenulated by impress of external coarse ornamentation.

Brachial valve interior.-Medially conjunct hinge plates, postero-median portions excavated and crenulated by slits of ctenophoridium. Hinge plates supported laterally by fulcral plates that floor dental sockets. Myophragm bisects area of muscle attachment to about midlength. Muscle field itself not discernible.

Comparison.-Maine material is similar to $\mathrm{Del}$ thyris kozlowskii, but lack of adequate material prohibits positive identification.

Foerste $(1903$, p. $710 ; 1909$, p. 92, pl. 2, figs. 31AB) described a species "Reticularia pegramensis," that possesses a median septum in the pedicle valve as well as dental plates and has all the characteristics of Delthyris s. s. Foerste's specimens do not, however, possess lateral plications as do most forms assigned to Delthyris. Amsden's species D. kozlowskii resembles $D$. pegramensis in all regards except that the former is strongly plicated. Some specimens of D. kozlowskii from Oklahoma bear very weak lateral plications, but none were observed without a trace. Maine material shows a transition between strongly plicated forms and ones with unplicated flanks.

Occurrence.-USGS loc. 3479-SD, Spencer Lake quadrangle, Somerset County, Maine.

Stratigraphic location.-Base of Hobbstown Formation (Upper Silurian).

Figured specimens.-USNM 126038, 126036, 126027, 126025.

\section{Genus HOWELLELLA Kozlowski, 1946 \\ Howellella? sp. \\ Plate 16, figures 6-7}

Pedicle valve interior.-Short gently diverging dental lamellae extend anteriorly about one-fifth length of valve. Low myophragm extends slightly anterior of dental lamellae. Shell subcircular in outline, highly convex. Hinge line straight, both lateral 
and anterior margins rounded. Median sulcus; flanks bear four to five low rounded costae separated by broad interspaces. Muscle field not discernible.

Discussion.-Only a few poorly preserved impressions of interior of pedicle valve were available. Material is not adequate for specific identification. Ignorance of fine ornamentation and of brachial valve makes generic assignment questionable.

Occurrence.-USGS loc. 2950-SD, Spencer Lake quadrangle, and 4841-SD, Attean quadrangle, Somerset County, Maine.

Stratigraphic location.-Basal part of the Hardwood Mountain Formation (Upper Silurian).

Figured specimens.-USNM 126020, 160134.

Unfigured specimens.-USNM 126021.

Howellella? cf. H. cyclopterus (Hall, 1857)

Plate 16, figures 8, 9

Exterior.-Evenly convex pedicle valve with transversely elongate, elliptical outline. Greatest width at straight hinge line. Pedicle valve interarea apsacline, slightly incurved. Anterior and lateral margins rounded. Median sulcus; flanks bear about six costae each. Costae rounded in cross section, separated by relatively broad interspaces. Fine ornamentation consists of striations terminating as tiny spines on edge each growth lamella.

Comparison.-No information is available regarding the interior of the pedicle or brachial valves; therefore, generic assignment is not certain. If shell is a delthyrinid, it is similar to H. cycloptera.

Occurrence.-USGS loc. 3499-SD, Spencer Lake quadrangle, Somerset County, Maine.

Stratigraphic location.-Beck Pond Limestone (Lower Devonian).

Figured specimens.-USNM 126257A.

"Howellella" tomheganensis Boucot, n. sp. Plate, 16, figures 10-18

Exterior.-Shells unequally biconvex, pedicle valve slightly more convex than brachial valve. Maximum width slightly anterior of straight hinge line. Shells transversely elliptical in outline. Lateral margins sharply rounded, anterior margin gently rounded. Brachial valve bears relatively narrow fold with subrectangular cross section, may bear indistinct medial groove. Sulcus form corresponds to fold, relatively rectangular in cross section. Anterior commissure uniplicate, crenulate. Relatively broad, rounded plications separated by narrow, relatively deep interspaces. Flanks bear seven to ten costae; average about nine. Costae widen anteriorly, show no evidence of bifurcation or origin by implantation. Pedicle valve interarea apsacline to orthocline, concave posteriorly, and slightly incurved. Brachial valve interarea anacline to orthocline. Pedicle valve interarea long, that of brachial valve very short. Delthyrium includes angle of about $45^{\circ}$, is bordered by thin, discrete deltidial plates normal to hinge line. Striae terminate in fringes of spines which overlap each concentric growth lamella. Sulcus from two to three times as wide as first plication lateral to it.

Pedicle valve interior.-Dental lamellae relatively short, extend anteriorly from one-fifth to one-third of length. Hinge teeth small, located on medial edge of hinge line. Muscle field deeply impressed in some specimens due to deposition of secondary material, weakly impressed in others; flabellate to elongate in form, bisected by low myophragm, consists of large, anteriorly located diductor impressions and pair of small, posteriorly located adductor impressions having rhomboidal outline. Dental lamellae diverge between second and third interspace lateral of sulcus. Umbonal regions of valve pitted. Peripheral regions of valve crenulated by external ornamentation; usually one or two fewer plications impressed than present on exterior. Dental lamellae indented by steps near edge of delthyrium; these steps serving as seats for deltidial plates.

Brachial valve interior.-Posteriorly located ctenophoridium lateral to which are discrete, basomedially inclined socket plates whose basal margins extend below bases of sockets. Posterior face each socket plate forms anterior side of socket. Low myophragm bisects area of unimpressed muscle attachment. Interior crenulated by external ornamentation impress.

Measurements.-A plot of pedicle valve length versus width (fig. 15A) shows a seemingly random distribution. This is probably due largely to mechanical deformation plus the fact that only a small size range of specimens was available. Relation between pedicle valve width and diductor muscle field width is essentially linear and shows a low degree of dispersion which may be due to deformation. Width of pedicle valve sulcus increases at a constant rate relative to valve width (fig. $15 C$ ) although a high degree of dispersion is present which may be due to mechanical deformation. The number of plications remains about constant relative to pedicle valve width although there is a slight tendency for increase in number with increase in size. Relation between pedicle valve width and sulcus width/first lateral interspace width is random (fig. 15E), probably due to deformation. Relation between pedicle valve width and first lateral interspace width is linear (fig. 15F) with high degree of dispersion possibly due to mechanical deformation. Relation of 
sulcus and first lateral interspace widths is linear (fig. 15G), with a high degree of dispersion. The high degree of dispersion shown by the measurements illustrates how mechanical deformation can alter characteristics of a sample to make growth rates and a growth curve slope difficult to understand.

The relation of diductor width and length in the pedicle valve is essentially linear, with a low degree of dispersion. Relation between pedicle valve width and diductor width is essentially linear with a low degree of dispersion (fig. 15B).

Plot of half number of plications against width of pedicle valve is normal with mode at nine plications (fig. 15D). Slight tendency for increase in number of plications from four to five in smaller specimens to five and six in larger specimens.

Comparison.-H.? nerei (Barrande) has a more angular and proportionately wider fold than " $H . "$ tomheganensis. " $H$." gaspensis, " $H$ " angustiplicata var. zaleszczykiensis, and " $H$." mckenzica have more lateral plications than does "H." tomheganensis, whereas " $H$." angustiplicata has fewer plications.

Occurrence.-USGS locs. 2820-SD, 2750-SD, and questionably 2814-SD, Brassua Lake quadrangle, Somerset County, Maine.

Stratigraphic location.-Tomhegan Formation

(Lower Devonian).

Holotype.-USNM 126016.

Figured specimens.-USNM 126032, 125026, 126017, 126045.

Measured specimens.-USNM 125889.

Genus ACROSPIRIFER Helmbrecht and Wedekind, 1923

Acrospirifer murchisoni (Castelnau, 1843)

Plate 16, figures $19-25$

Spirifer murchisoni (Castelnau, 1843), see Clarke, 1900, p. 46-48, pl. 6, figs. 26-30.

Exterior.-Unequally biconvex shells, pedicle valve about $11 / 2$ times as convex as brachial valve. Shells transversely elliptical, greatest width at hinge line. Short ears present on well-preserved specimens, but usually broken off. Brachial valve bears median fold with angular cross section, apex rounded. Pedicle valve sulcus corresponds to brachial valve fold. Five to seven plications on each flank. Lateral plications have rounded cross section, separated by wide, rounded interspaces. Pedicle valve interarea gently apsacline, concave posteriorly, beak slightly incurved. Brachial valve interarea gently apsacline to orthocline. Pedicle valve interarea relatively long, that of brachial valve relatively short. Delthyrium open, includes angle of about $90^{\circ}$, bordered by pair narrow deltidial plates inserted normal to interarea. Anterior commissure uniplicate, crenulate. Lateral margins rounded, anterior margin nearly straight. Well-preserved specimens have fine, radiating striae which terminate as fringe of minute spines over anterior edge of each growth lamella. On most specimens fine ornamentation is abraded, shells appear to lack spines or striations between plications. Interarea smooth except for growth lines which parallel hinge line.

Pedicle valve interior.-Short dental plates border sides of delthyrial cavity but become obsolete in larger specimens due to extensive deposition of secondary material in umbonal and delthyrial cavities. Hinge teeth stout, triangular in cross section, located medial to hinge line. Muscle field very deeply impressed in deposits of secondary material at posterior of valve. Muscle field extends to about midlength, relatively narrow. Consists of pair of median, narrow adductor impressions bounded by larger, elliptical diductor impressions. Posterior face of delthyrial cavity bounded by rhomboidal impression of pedicle callist produced anteriorly, by deposition of secondary material, to a point forward of posterior tip of diductor impressions. Secondary material laid down in umbonal cavities is pitted. Valve peripheral regions strongly crenulated by impress of external ornamentation. Short myophragm bisects posterior part of muscle field. Medial face of each dental plate bears step in which to seat a deltidial plate.

Brachial valve interior.-Ctenophoridium situated on posterior wall of notothyrial cavity and laterally bounded by narrow, vertically inclined socket plates which curve to floor dental sockets. Myophragm bisects unimpressed muscle attachment area. Sockets shallow, anterolaterally directed. Interior strongly crenulated by external ornamentation impress.

Measurements.-Relation between length and width of pedicle valve is essentially linear with a slope of about $60^{\circ}$ (fig. 16A). Degree of dispersion is not high, actual amount of dispersion increases with size, suggesting percentage variation remains about constant. Sample is normally distributed.

Relation of pedicle valve width and first lateral interspace width is linear, shows a positive slope of about $85^{\circ}$ with low degree of dispersion (fig. $16 B$ ). Relation of pedicle valve width to sulcus width is linear; slope about $75^{\circ}$ indicates sulcus expands at a much greater rate than does the first lateral interspace. The degree of dispersion of the sulcus and valve width is not great (fig. $16 \mathrm{C}$ ). Relation between sulcus width and first lateral interspace width is curved; strong tendency for the sulcus to increase in width at a greater rate than the lateral interspace with increase in sulcus width (fig. 16D). Relation between pedicle valve width and the ratio of sulcus 

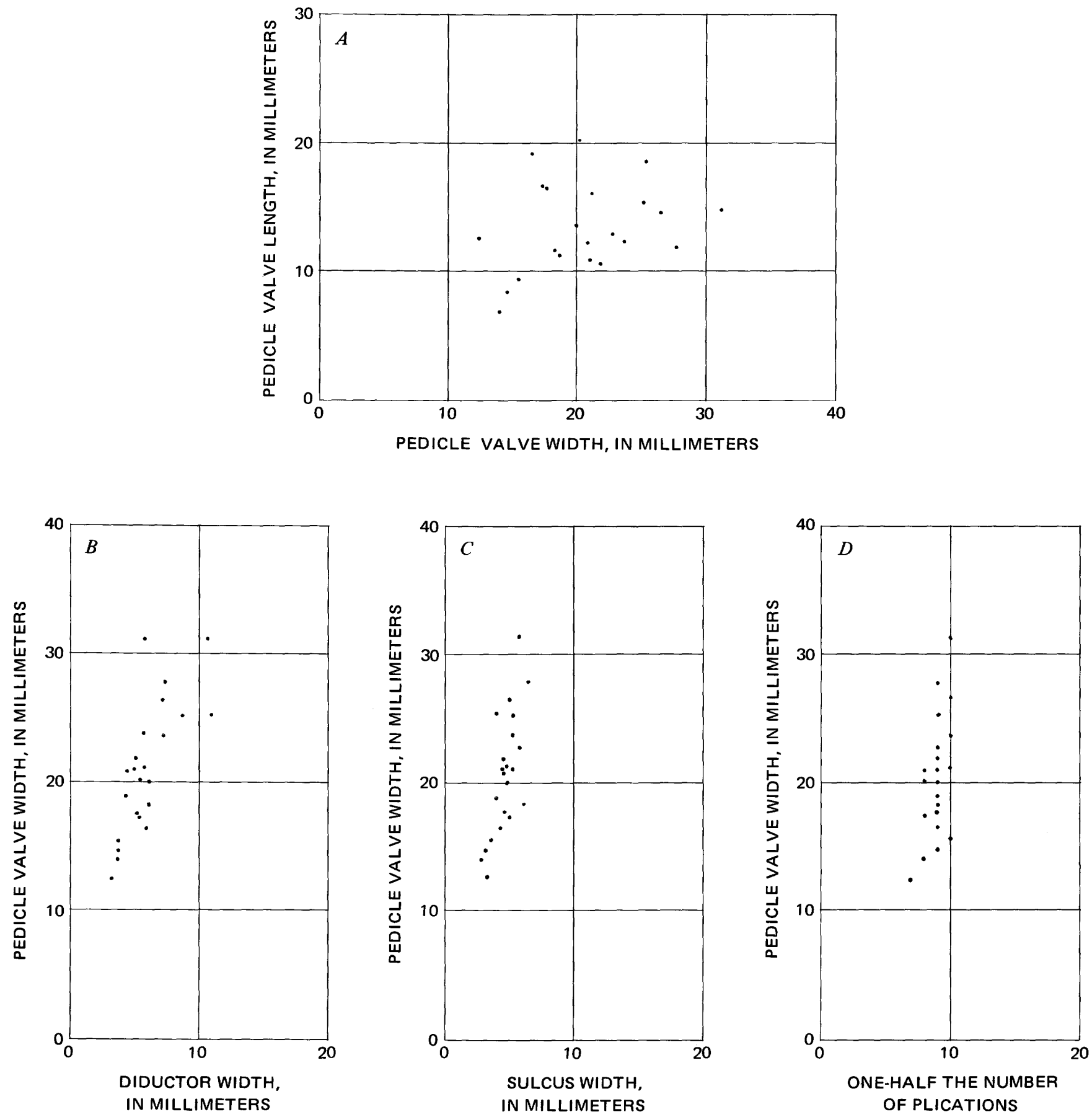

Figure 15.-Measurements of "Howellella" tomheganensis Boucot n. sp. Tomhegan Formation, USGS loc. 2820-SD, Brassua Lake quadrangle, Somerset County, Maine.

width to first lateral interspace width is essentially linear but with a much higher degree of dispersion than the component measurements suggest, probably because the use of ratios tends to multiply the amount of variation (fig. $16 E$ ).

Relationship between width of fold and sulcus with the respective first lateral interspace and plication is linear, with moderate degree of dispersion. Slight tendency, in pedicle valves in sample from
USGS loc. 2720-SD, for the sulcus to expand at greater rate than lateral interspace when sulcus width of about $3 \mathrm{~mm}$ reached. Relationship between width of valves and sulcus width/first lateral interspace width and fold width/first lateral plication width is nearly random, because ratios are used. Relationship between valve width and widths of first lateral plication and interspace is essentially linear; moderate degree dispersion which increases 

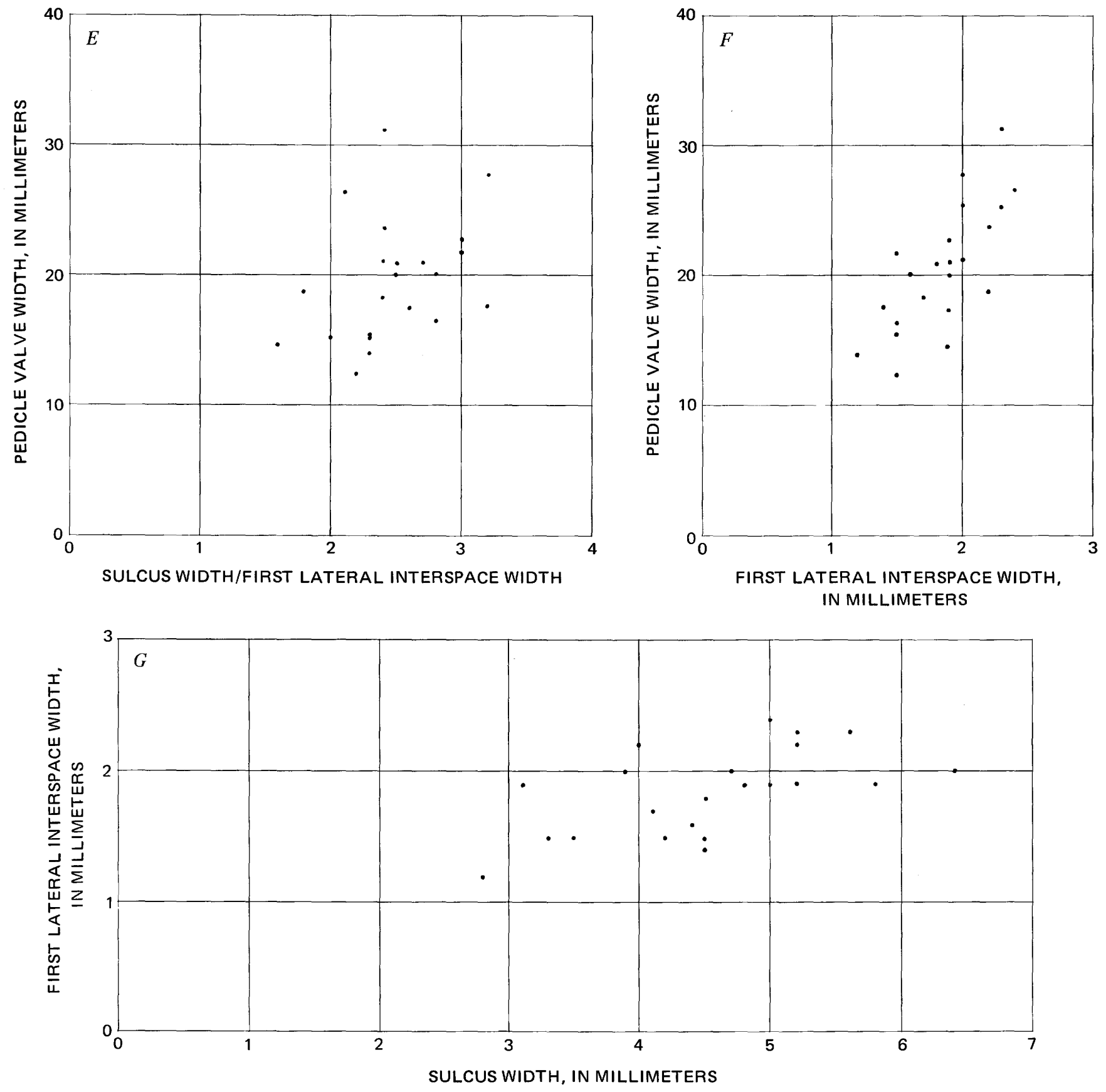

Figure 15.-Continued.

with increase in size at greater rate than if percentage variation remained constant.

Relationship between pedicle valve width and width of the diductor field essentially linear, steeply sloping, and indicates the muscle field width increases more slowly than valve width. (fig. 16G) Dispersion is low. Relationship between diductor width and length is essentially linear with a moderate degree of dispersion (fig. 16F).

Comparison.-Acrospirifer hartleyi (Schuchert,
1913) and A. angularis (Schuchert, 1913) are probably synonyms of $A$. murchisoni, but adequate material is not available for comparison.

Occurrence._USGS loc. 3482-SD, 3090-SD, 2847SD, 2827-SD, 2890-SD, 2718-SD, 2727-SD, 2729SD, 2777-SD, 2705-SD, 2862-SD, 2766-SD, 2834SD, 3088-SD, 2089-SD, 2767-SD, Somerset and Piscataquis Counties, Maine.

The following USGS localities provided $A$. cf. $A$. murchisoni: 2774-SD, 2733-SD, 2792-SD, 2857-SD, 

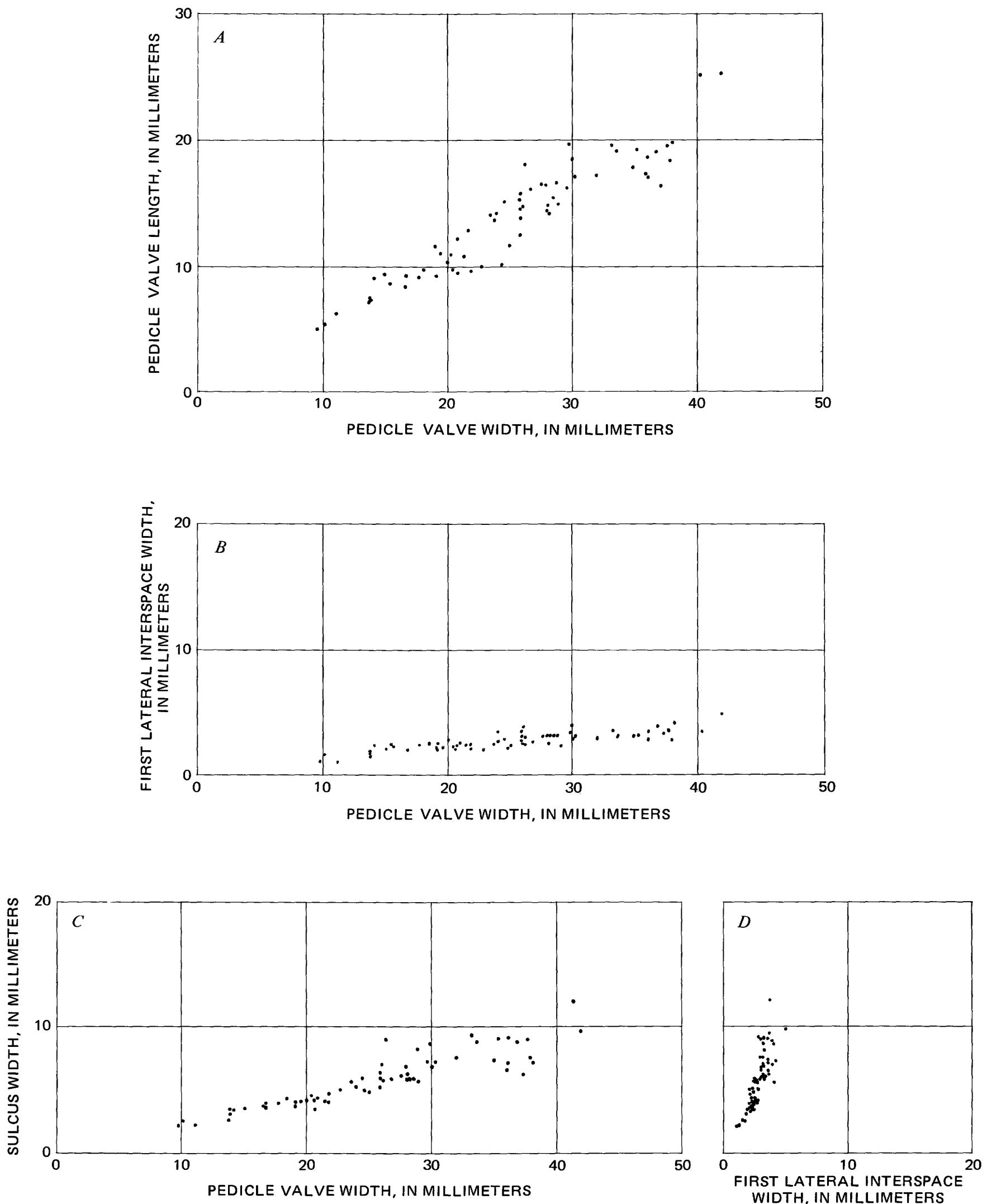

FIGURE 16.-Measurements of Acrospivifer murchisoni (Castelnau, 1843). Lower sandstone of Tarratine Formation, USGS loc. 2718-SD, Long Pond quadrangle, Somerset County, Maine. 

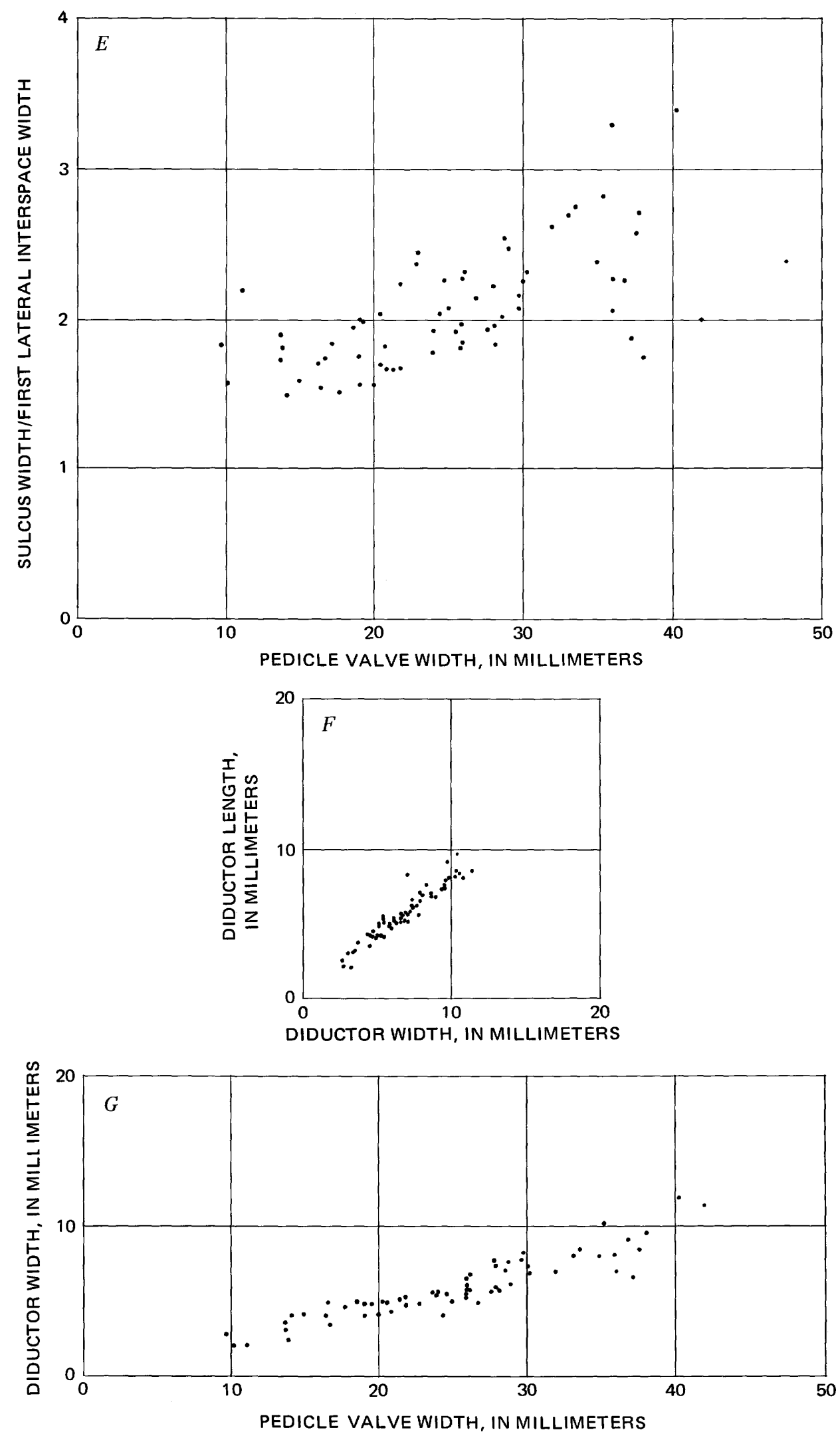

Figure 16.-Continued. (Continued on following page). 


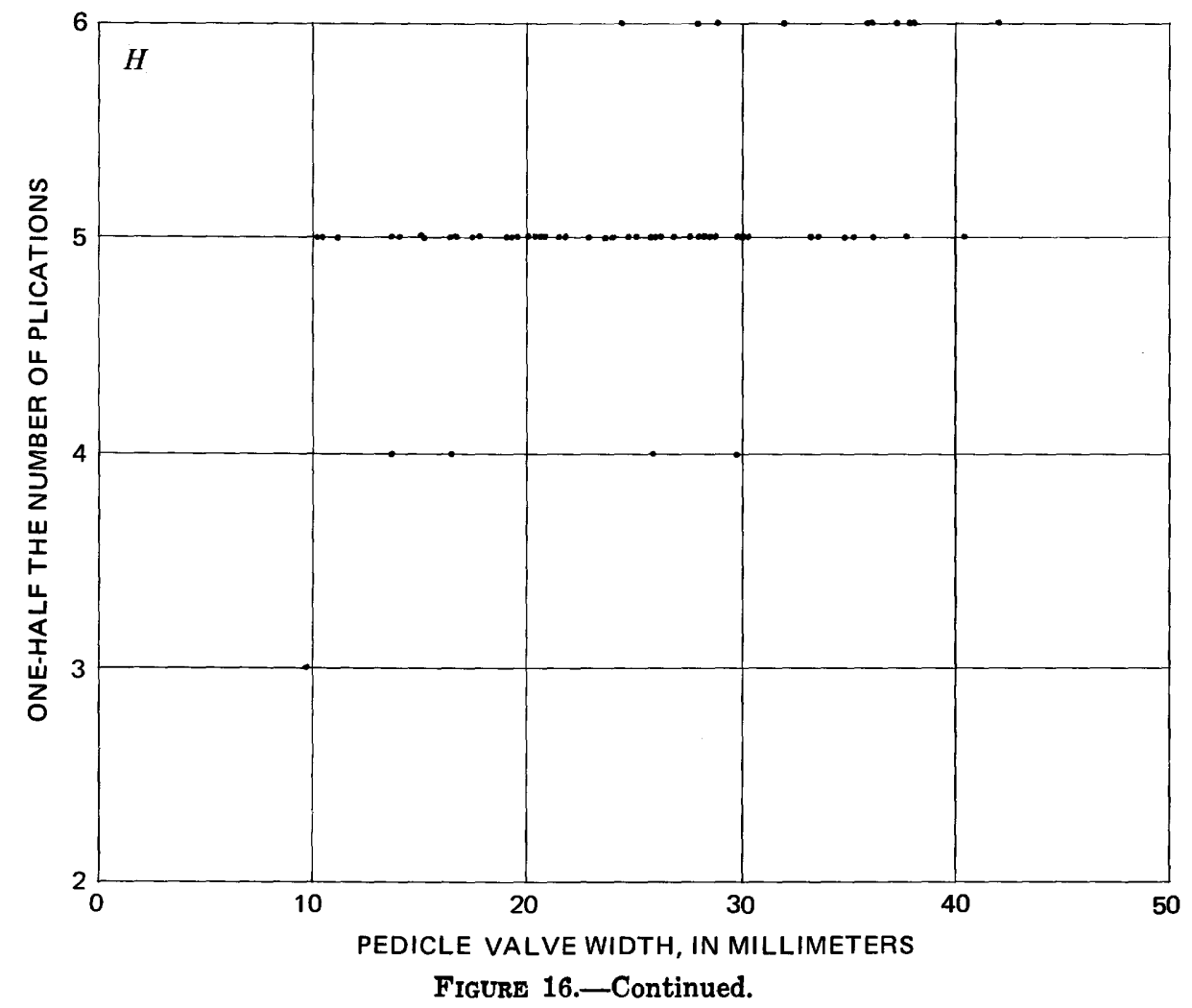

2725-SD, 2810-SD, 2864-SD, 3474-SD, 2806-SD, 2824-SD, 2797-SD, 2832-SD, 2717-SD, 2691-SD, 2710-SD, 2861-SD, 2735-SD, 2769-SD, 2837-SD, Somerset County, Maine.

Stratigraphic location.-Seboomook Formation (Lower Devonian), McKenney Ponds Member of the Tarratine Formation (Lower Devonian), and the upper and lower sandstones of the Tarratine Formation (Lower Devonian).

Figured specimens.-USNM 126047, 126042, $126043,127386$.

Measured specimens.-USNM 125863-125864.

Unfigured specimens.-USNM 126526-126556, 126565-126568.

\section{Acrospirifer atlanticus (Clarke, 1907)}

Plate 17, figures 1-9

Spirifer primaevus Steininger var. atlanticus Clarke, 1907, p. 260-262.

Spirifer gaspensis Williams and Breger, 1916, p. 107-113, pl. 4, fig. 7, non Billings, 1874.

Exterior.-Unequally biconvex shells, pedicle valve having greater degree convexity. Greatest width at straight hinge line. Shell outline subcircular to alate, deformation altered outlines to a certain extent. Brachial valve bears broad, median fold with angular cross section, pedicle valve has corresponding sulcus. Pedicle valve interarea apsacline, concave posteriorly, beak slightly incurved. Brachial valve interarea gently anacline. Pedicle valve inter- area long, brachial valve interarea short. Pedicle valve delthyrium includes angle of about $60^{\circ}-90^{\circ}$, laterally bordered by pair narrow deltidial plates inserted normal to interarea. Six to 14 lateral plications, depending on width of valve, 10 to 12 usual number among specimens studied. Anterior commissure uniplicate, crenulate.

Radial striae terminate as fringe of spines over anterior margins of each growth lamella. Fine ornamentation variably preserved depending upon degree abrasion undergone by specimen; some shells partly smooth, partly striate, and partly fimbriate. Lateral margins gently rounded, anterior margin almost straight. Interarea smooth except for growth lines which parallel hinge line.

Pedicle valve interior.-Short, bladelike hinge teeth on medial side hinge line, supported by short, dental lamellae which are convex medially. Dental lamellae largely obsolete due to deposition of secondary material in umbonal cavities. Muscle field deeply impressed, restricted to posterior half of valve. Muscle field relatively elliptical to subcircular in outline, consists of narrow, median adductor impressions flanked laterally by elongate, anteriorly expanding diductor impressions. Diductor impressions striate, extend posteriorly into pair of pointed chambers excavated in secondary material deposited in delthyrial cavity. Pad of secondary material slightly anterior of posterior part of diductor im- 
pressions bears relatively small, diamond-shaped pedicle callist. Interior deeply impressed by external ornamentation. One to five fewer lateral plications impressed on interior than are present on valve exterior.

Brachial valve interior.-Ctenophoridium located on posterior face of notothyrial cavity, laterally flanked by pair of socket plates whose lower medial edges do not extend below base of sockets. Myophragm bisects unimpressed muscle field and reaches to about the midlength.

Measurements.-The relationship between length and width of pedicle valve is linear (fig. 17G). The high degree of dispersion suggests mechanical deformation altered the expected distribution.

The width of sulcus increases linearly with increase in width of pedicle valve (fig. $17 \mathrm{~A}$ ), with a moderate degree of dispersion. The width of the first lateral interspace increases linearly with relation to the pedicle valve width (fig. $17 B$ ), but the slope is much lower than that for the sulcus width, indicating that the sulcus expands at a greater rate than the first lateral interspace. The relationship between sulcus width and first lateral interspace width is linear, with a moderate degree of dispersion (fig. $17 C)$. The low slope indicates sulcus expands at greater rate than interspace. The relationship between pedicle valve width and the ratio of sulcus width to first lateral interspace width is linear, with a very high degree of dispersion (fig. $17 E$ ), induced by the use of the ratio; however, it indicates that the sulcus becomes proportionately wider with increase in width of pedicle valve, that is, it flares anteriorly.

The relationship between pedicle valve width and number of lateral plications on one side of sulcus is linear, with a low slope, and a moderate degree of dispersion (fig. 17F). Smaller specimens average about six plications on each side of the sulcus, larger ones about ten. Relation between width and length of diductor field is linear, with an increasing degree of dispersion with increase in size (fig. 17D). Slope of about $45^{\circ}$ suggests muscle field expands about equally in both directions.

Comparison.-Acrospirifer intermedius (Hall, 1859) has fewer lateral plications than $A$. atlanticus.

Discussion.-Clarke (1909, p. 83, pl. 19, figs. 512) erroneously cited Tomhegan Point as the locality for specimens having the same aspect as those from adjacent Baker Brook Point. Rocks of Tomhegan Point belong to the Tarratine Formation; those of Baker Brook Point belong to the Tomhegan Formation.

The material cited as "Spirifer cf. S. तuodenarius (Hall)" by Williams and Breger (1916, p. 104-105, pl. 4, figs. 3-4) is small specimens of $A$. atlanticus. Williams and Breger's locality 1061 B', cited as Little Brassua Lake (1916, p. 109), was not reexamined; may actually refer to mouth of Stony Brook, as judged from lithology of their specimens.

Small specimens of $A$. atlanticus, less than about $3 \mathrm{~cm}$ in width, are difficult to distinguish from $A$. murchisoni, owing to similar shape and ornamentation.

Occurrence.-USGS locs. 2852-SD, 2820-SD, 2873-SD, 2750-SD, 2752-SD, 2841-SD, 2842-SD, Brassua Lake quadrangle, Somerset County, Maine. The following localities provided $A$. cf. $A$. atlanticus: 2840-SD, 2730-SD, 2723-SD, 2814-SD, 2839-SD, Brassua Lake quadrangle, Somerset County, Maine.

Stratigraphic location.-Tomhegan Formation.

Figured specimens.-USNM 126041, 126019, 126031, 126163, 127388.

Measured specimens.-USNM 125866, 125865.

Unfigured specimens.-USNM 125939, 126557$126564,126578$.

\section{Acrospirifer sp. 1 \\ Plate 17, figures 10-14}

Exterior.-Shells subequally convex. Greatest width at straight hinge line. Shells transverse. Brachial valve bears fold with low rounded to almost flat cross section, pedicle valve has corresponding sulcus. Seven to eight plications each flank. Costae have rounded cross section, separated by rounded interspaces. Lateral margins rounded, anterior margins almost straight. Concentric growth lines crossed by radial striae terminating as fringe of spines over anterior margin each lamella. Anterior commissure uniplicate, crenulate. Pedicle valve interarea apsacline, beak slightly incurved. Delthyrium open, includes angle of about $60^{\circ}$. Delthyrium probably bordered by pair narrow deltidial plates. Pedicle valve interarea relatively long, brachial valve interarea relatively short.

Pedicle valve interior.-Short dental lamellae almost entirely obsolete due to deposition secondary material in umbonal cavities. Medial face each dental lamella indented by step which probably served to seat deltidial plate. Muscle field deeply impressed in secondary material which lines delthyrial cavity and posterior part of valve. Muscle field tripartite, consists of elongate, median adductor impression laterally bounded by pair anteriorly expanding diductor impressions. Peripheral regions crenulated by impress external ornamentation.

Brachial valve interior.-Small ctenophoridium located posterior face notothyrial cavity, laterally flanked by discrete socket plates directly attached to shell walls. Muscle field not impressed, myo- 

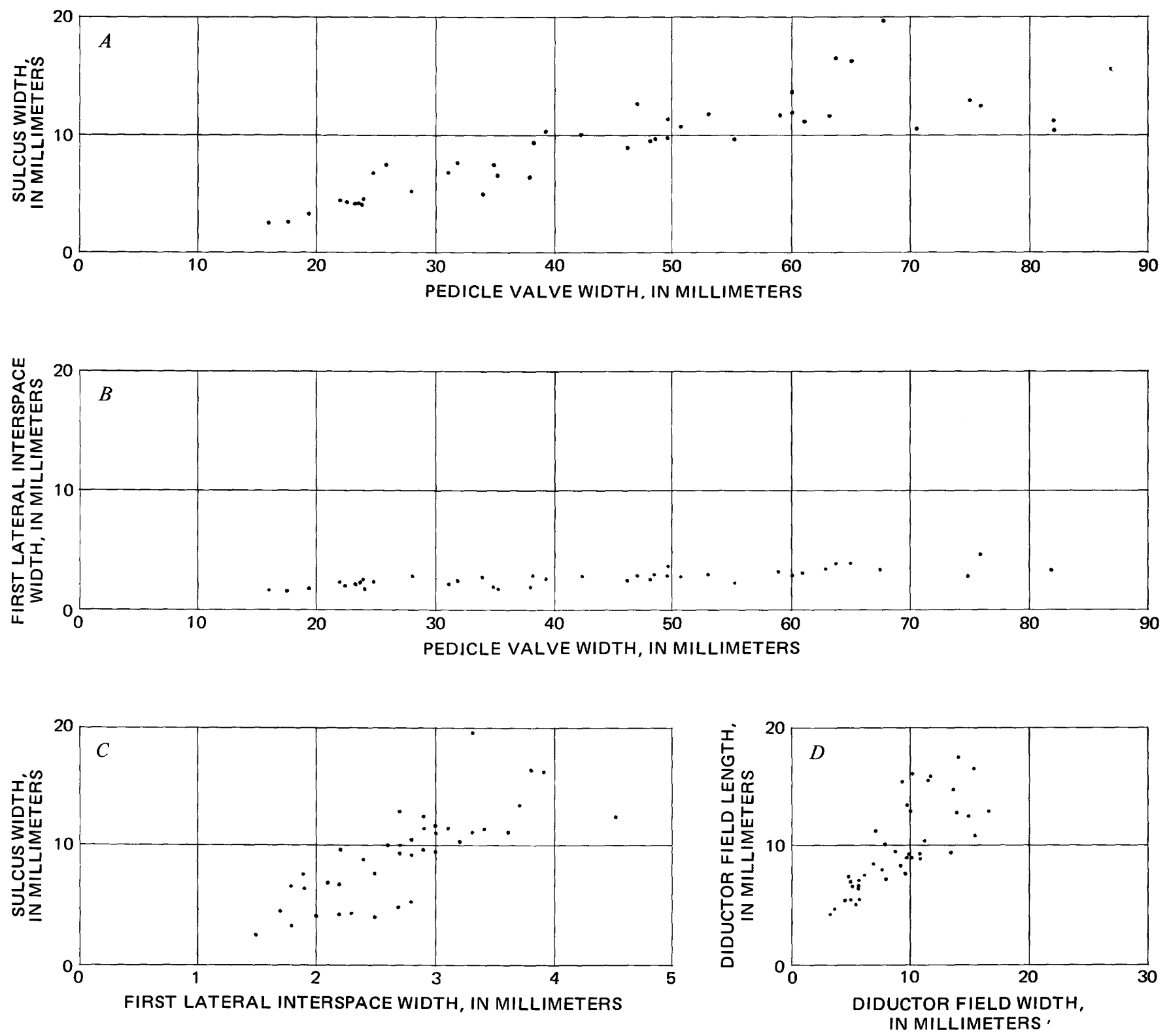

FIGURE 17.-Measurements of Acrospirifer atlanticus (Clarke, 1907). Tomhegan Formation, USGS locs. 2750-SD, 2820SD, and 2873-SD, Brassua Lake quadrangle, Somerset County, Maine.

phragm extends to about midlength. Interior crenulated by impress of external ornamentation.

Comparison.-Material morphologically unlike other acrospiriferids known to me.

Occurrence.-USGS loc. 2796-SD, Pierce Pond quadrangle, Somerset County, Maine.

Stratigraphic location.-Lower sandstone of the Tarratine Formation (Lower Devonian).

Figured specimens.-USNM 126090, 126075.

\section{Acrospirifer sp. 2}

Plate 18, figures 1-5

Exterior.-Subequally biconvex shells, both valves very gently convex. Greatest width at straight hinge line. Lateral and anterior margins rounded. Brachial valve bears broad, low median fold with very low, rounded cross section. Pedicle valve has a sulcus corresponding to brachial valve fold. Low, rounded costae, about five or six on each flank, separated by low, rounded interspaces. Anterior commissure uniplicate, crenulate. Pedicle valve interarea gently apsacline, slightly concave. Brachial valve interarea orthocline to gently anacline. Pedicle valve interarea relatively long, brachial valve interarea relatively short. Interarea smooth except for growth lines which parallel hinge line. Concentric growth lines crossed by striae terminate as fringe of spines over anterior edge growth lamellae. Delthyrium includes 

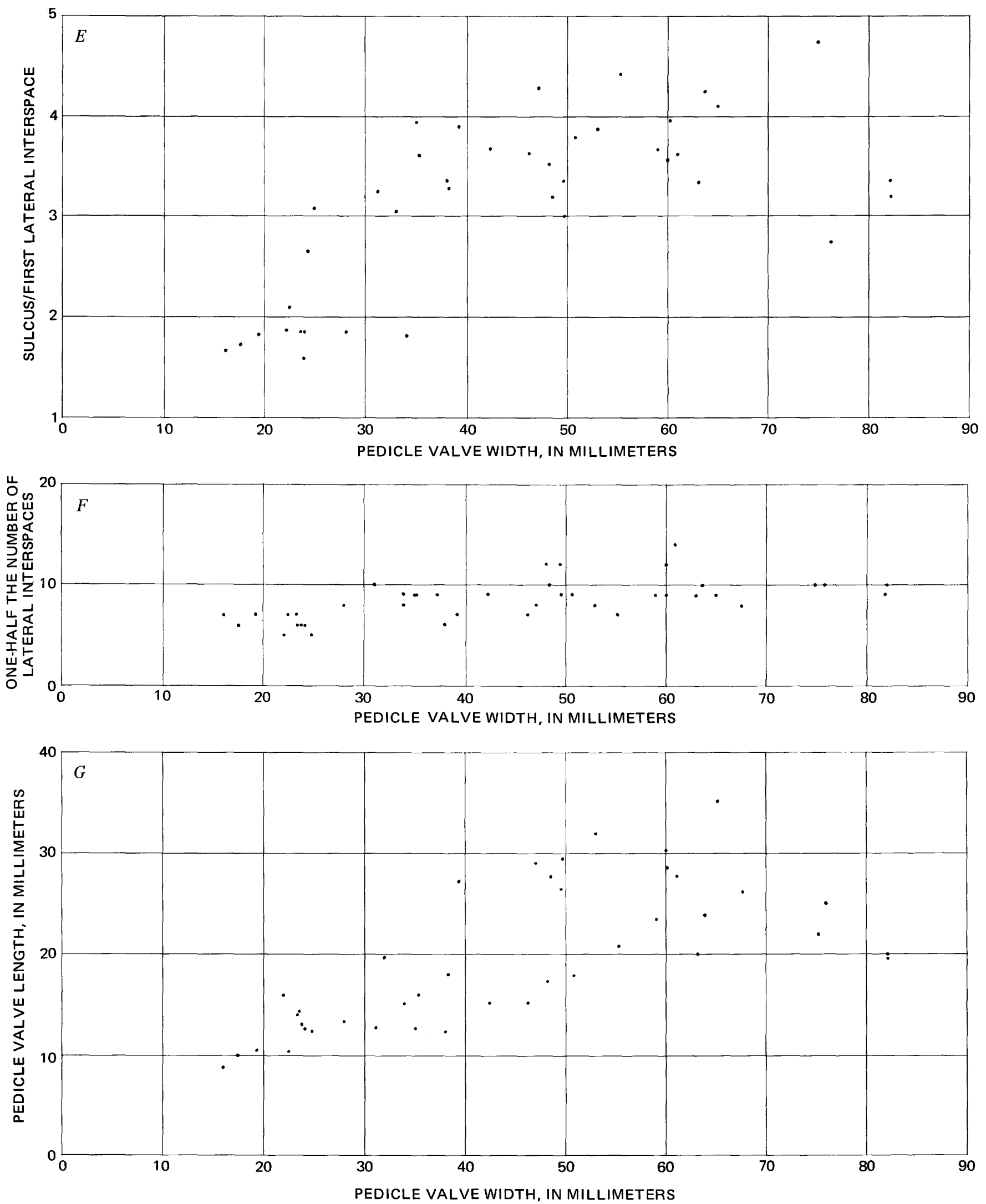

FIGURE 17.-Continued. 
angle of about $60^{\circ}$, partly closed in apical region by convex plate.

Pedicle valve interior.-Hinge teeth stubby, situated inner margins hinge line. Dental lamellae short, almost entirely obsolete due to deposition secondary material in umbonal cavities. Muscle field deeply impressed in secondary material lining rear of valve. Muscle field consists of median adductor impression with subparallel sides flanked by pair laterally expanding diductor impressions. Short myophragm divides posterior half muscle field, ends against pedicle callist, on diamond-shaped pad of callous, just anterior of tips of diductor impressions. Peripheral regions crenulated by impress of external ornamentation.

Brachial valve interior.-Ctenophoridium situated rear of notothyrial cavity, laterally flanked by pair discrete socket plates attached directly to valve walls. Adductor impressions deeply impressed posteriorly, fade anteriorly, bisected by short myophragm.

Comparison.-Form unlike other acrospiriferids known to me.

Occurrence.-USGS loc. 2872-SD, Pierce Pond quadrangle, Somerset County, Maine.

Stratigraphic location.-Lower sandstone of the Tarratine Formation (Lower Devonian).

Figured specimens.-USNM 126089, 126113.

Genus ANTISPIRIFER Williams and Breger, 1916

Antispirifer harroldi Williams and Breger, 1916

Plate 18, figures 6-14

Antispirifer harroldi Williams and Breger, 1916, p. 116-117, pl. V, figs. 1-13.

Exterior.-Shells unequally convex, brachial valve more convex than relatively flat pedicle valve. Maximum width shell is at straight hinge line. Brachial valve bears median fold, broad, gently rounded or subrectangular cross section, pedicle valve bears corresponding sulcus. Anterior part sulcus pedicle valve very steeply inclined as opposed to very gently inclined posterior part. Four to seven angular plications on each flank separated by narrow interspaces. Closely spaced growth lamellae crossed by striations terminating as fringes of spines over anterior edge each growth lamella. Deltidial plates not observed, delthyrium includes angle about $60^{\circ}-90^{\circ}$. Pedicle valve interarea very gently apsacline, long, brachial valve interarea short, anacline.

Anterior commissure uniplicate, crenulate. Lateral margins evenly rounded, anterior margin gently rounded to straight. Anterior part pedicle valve approaches resupinate condition. Measurements indicate sulcus ceased widening when pedicle valve attained width of about $23 \mathrm{~mm}$, although shell still capable of growing wider. Ratio of sulcus width to first groove width usually between 2.0 and 3.0, averages about 2.5. Anterior part of fold in shells more than about $15 \mathrm{~mm}$ wide tends to expand more rapidly than adjacent plications, probably due to lateral part of fold extending down over lateral margins of sulcus. Fold tends to stop expanding in width after shell attains width of about $23 \mathrm{~mm}$, as for sulcus.

Pedicle valve interior.-Pedicle valve dental lamellae short, rapidly obsolescent with increasing valve size. Muscle field small, subcircular in outline, restricted to posterior part of valve. Hinge teeth low, stout, situated along lateral edges delthyrium. Muscle field tripartite, consists of median, elongate, anteriorly expanding adductor impression laterally flanked by pair laterally expanding diductor impressions. Posterior tips diductor field extend into secondary material lining delthyrial cavity as two pits separated by ridge bearing pedicle callist. Peripheral regions of valve strongly crenulated by impress external ornamentation. Secondary material lines posterior part of valve, renders surface relatively smooth. About one less lateral plication tends to be impressed on interior than is present on exterior.

Brachial valve interior.-Small ctenophoridium located posterior face notothyrial cavity, laterally flanked by pair of socket plates whose basal margins do not extend below bottom of sockets. A few specimens possess basally supporting crural plates whose basal margins extend below bottom of sockets medially, indicating howellellid derivation this group of shells. Muscle scars weakly impressed, consist of pair adductor impressions noticeable only at posterior of notothyrial cavity, and separated by low myophragm. Spire observed in one specimen but exact nature not worked out.

Measurements.-The relationships between length and width of the pedicle and brachial valves is essentially linear, with a moderate degree of dispersion (figs. 18B-E). The distributions are normal, and the mode of brachial valves from USGS loc. 2720-SD is much larger than for pedicle valves in the same bed, suggesting that sorting was important in the creation of the assemblage. Plots for both valves show about the same degree of dispersion from both samples suggesting deformation was not important in molding either sample.

The number of plications relative to valve width is normally distributed (figs. $18 F-I$ ), five being the number usually present on each half of either valve. Smaller specimens tend to have three to five plication; larger ones five to seven.

A linear relation exists between width of valves 
and the respective fold and sulcus (figs. $18 A, K, L$ ). Degree of dispersion increases rapidly with size, to such an extent that there is a suggestion that a greater percentage of variation has been introduced in the larger specimens.

Other measurements are shown on figure 18.

Discussion.-Schuchert (in Pirsson and Schuchert 1914, p. 223) described species subsequently described by Williams and Breger (1916. pp. 114118) as $A$. harroldi, but he cited some specimens figured by Clarke (1909, pl. 20, figs. 9-12) as cotypes. Unfortunately, the material figured by Clarke is too poorly preserved to be generically identifiable, therefore not clear if Schuchert's species "Spirifer" pirssonae is synonymous with $A$. harroldi.

Caster's (1939, p. 156-159) "Acrospirifer olssoni" as judged from plates and descriptions probably belongs to Antispirifer. Lack of adequate Colombian material prevents specific comparison: Caster's plates indicate that South American and North American species are very similar.

Occurrence.-USGS locs. 2722-SD, 2721-SD, 2720-SD, 2765-SD, 2823-SD, 2719-SD, 2783-SD, 2821-SD, 2861-SD, Somerset County, Maine.

Stratigraphic location.-Lower sandstone of the Tarratine Formation (Lower Devonian) and the Tarratine Formation.

Figured specimens.-USNM 126040, 126039, 126034, 126028, 126024, 126033.

Unfigured specimens.-USNM 126265-126271.

Measured specimens._USNM 125818, 125844125846.

Genus COSTELLISPIRIFER Boucot, new genus

Type species.-Spirifer perimele Clarke, 1907, p. 253-254.

Diagnosis.-Costellispirifer characterized by numerous closely spaced costellae separated by narrow, V-shaped interspaces. Costellae have gently rounded cross section. Crural plates absent under socket plates. Fold has rounded cross section.

\section{Costellispirifer perimele (Clarke, 1907)}

Plate 18, figures 15-20

Exterior-Unequally biconvex shells, pedicle valve having greater degree convexity. Greatest width at straight hinge line. Lateral and anterior margins rounded. Brachial valve bears broad, median fold with low, rounded cross section, pedicle valve has corresponding sulcus. Shells subcircular to transversely elongate. Eight to fifteen costellae on each flank. Costellae have low, rounded cross section separated by narrow v-shaped interspaces. Medially located costellae tend to bifurcate anteriorly. Pedicle valve interarea gently concave posteriorly, gently apsacline to orthocline, brachial valve interarea orthocline to gently anacline. Pedicle valve interarea relatively long, brachial valve interarea relatively short. Delthyrium open, includes angle of about $60^{\circ}$, laterally bordered by narrow, discrete deltidial plates inserted normal to interarea. Anterior commissure uniplicate, crenulate. Radial striae terminate as fringe of minute spines over anterior edge each concentric growth lamella.

Pedicle valve interior.-Short dental plates support stubby hinge teeth, laterally border weakly to moderately well impressed muscle field. Dental lamellae become increasingly obsolete in large shells due to deposition secondary material in umbonal cavities. Muscle field narrow, may extend to midlength or point about three-quarters distance to anterior margin. Muscle field consists of median, narrow adductor track divided by low myophragm, laterally bounded by pair narrow diductor impressions. Interior of shell strongly crenulated by impress external ornamentation.

Brachial valve interior.-Small ctenophoridium located on posterior wall of notothyrial cavity, laterally bounded by anterolaterally diverging socket plates whose lower margins are not supported by crural plates. Short myophragm bisects unimpressed area of muscle attachment.

Measurements.-The relationship between length and width of the pedicle valve is essentially linear, with a high degree of dispersion (fig. 19A). The high degree of dispersion is probably due to mechanical deformation affecting most fossils at this locality (USGS loc. 2750-SD). The pedicle valve has about eight to fourteen costellae on each half of the valve, with the mode at about eleven (fig. 19B). Relation between sulcus width and first lateral interspace width is linear in the region studied, with a high degree of dispersion, and an acute change in slope, in the region, of about $1 \mathrm{~mm}$ lateral interspace width is indicated (fig. 19C). Relationship between pedicle valve width and first lateral interspace width is linear, with a high degree of dispersion (fig. 19D). Relation of sulcus width and pedicle valve width is linear (fig. 19E). Relation of pedicle valve width to the ratio between width of sulcus and first lateral interspace is linear (fig. $19 F$ ), suggesting sulcus width increases at a greater rate than first lateral interspace width. Relationship between width of pedicle valve and diductor width is linear (fig. 19G).

Comparison.-C. perimele may be conspecific with material described from Highland Mills, N. Y. (Boucot, 1959b). Specimens assigned by Dunbar (1919, p. 87) to "Spirifer" worthenanus and "Spirifer" engelmanni may belong to Costellispirifer but inade- 

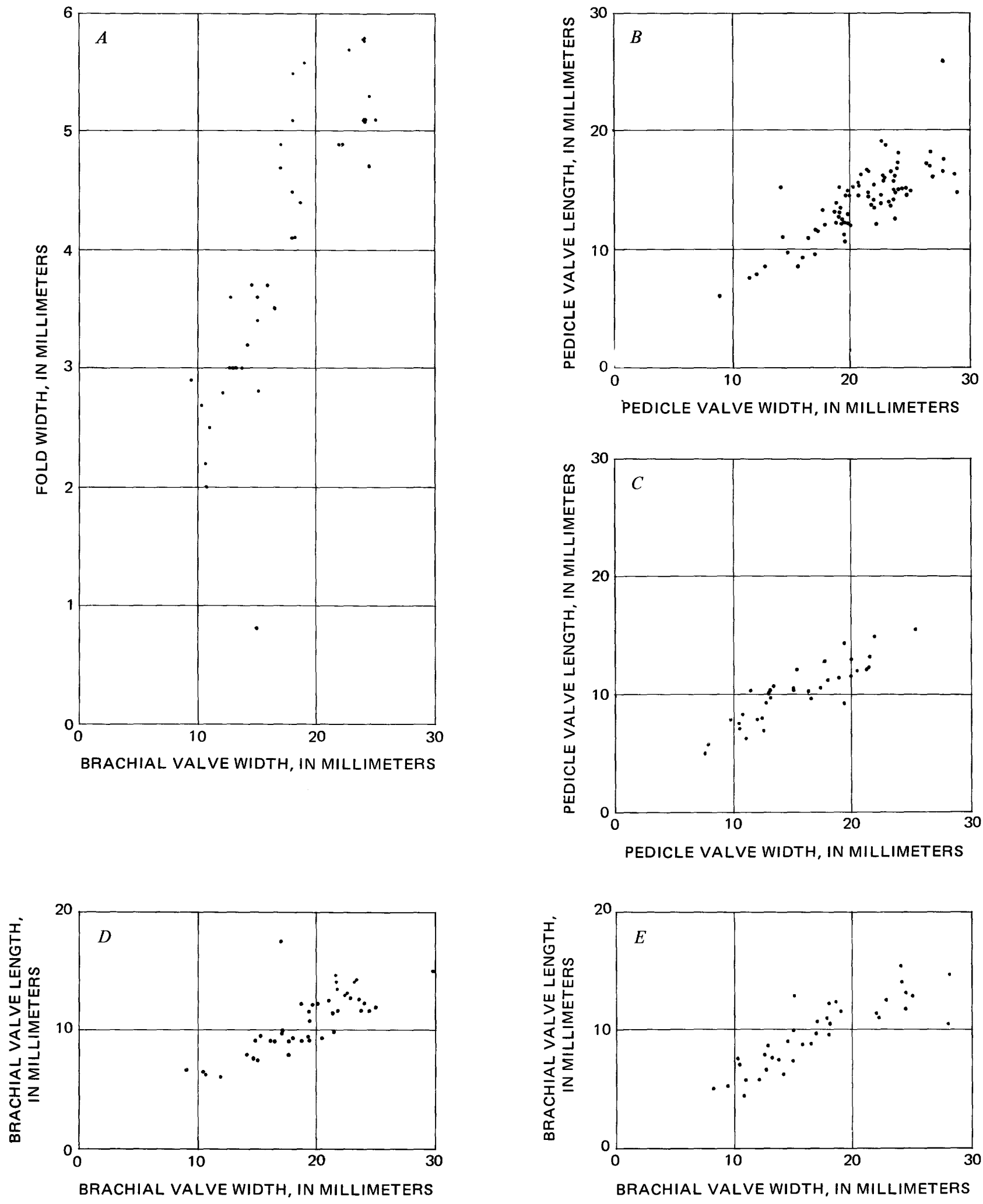

FIGURE 18.-Measurements of Antispirifer harroldi Williams and Breger, 1916. Lower sandstone of Tarratine Formation, Long Pond quadrangle, Somerset County, Maine. $A$, brachial valve width versus width of fold; USGS loc. 2721-SD. $B$, length versus width of pedicle valves; USGS loc. 2720-SD. $C$, length versus width of pedicle valves; USGS loc. 2721-SD. $D$, length versus width of brachial valves; USGS loc. 2720-SD. $E$, length versus width of brachial valves; USGS loc. 2721-SD. 

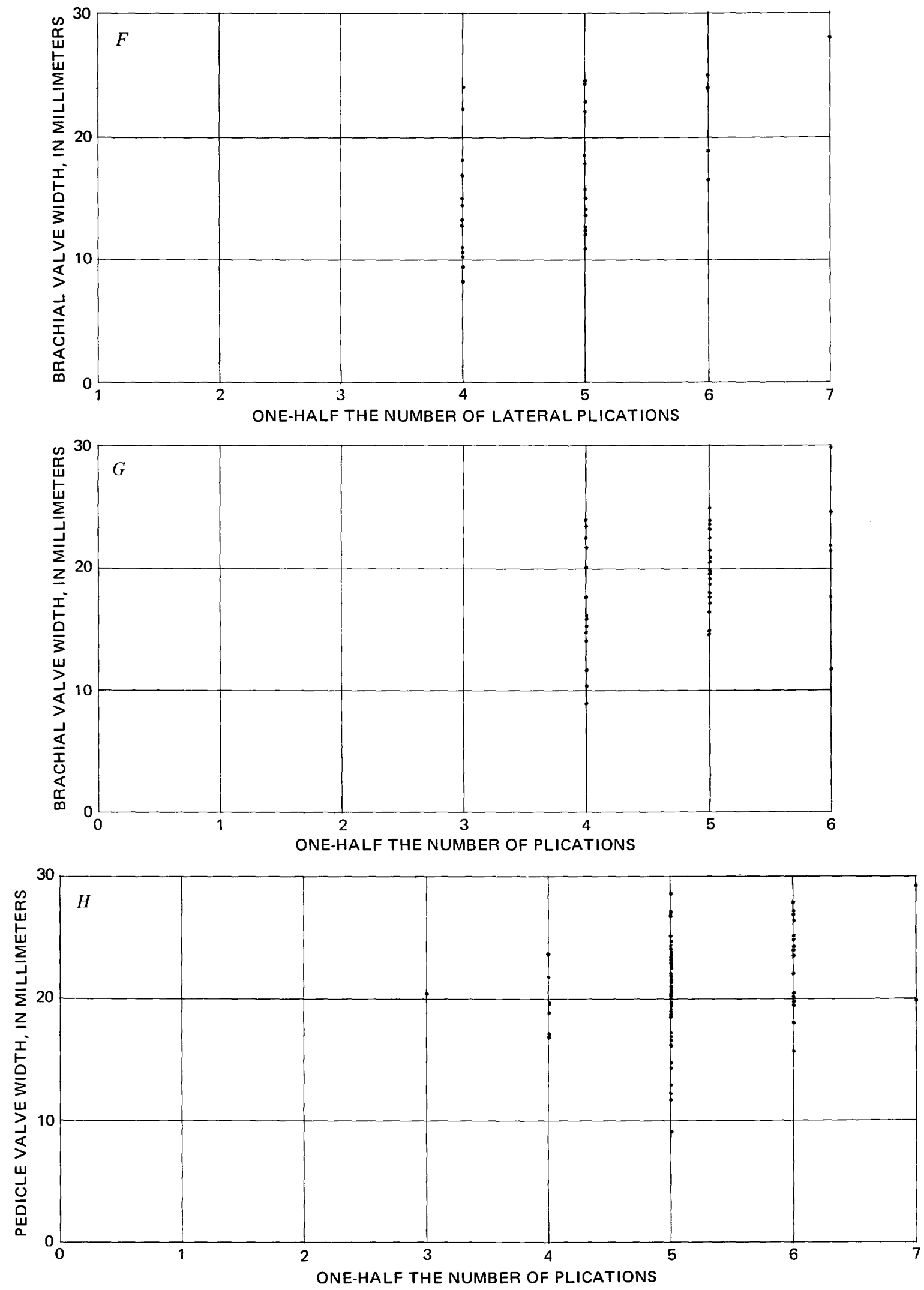

Figure 18.-Continued.

$F$, width of brachial valve versus one half the number of lateral plications; USGS loc. 2721-SD. G, width of brachial valve versus one half the number of plications; USGS loc. 2720-SD. $H$, width of pedicle valve versus one half the number of external plications; USGS loc. 2720-SD. (Continued on following page). 

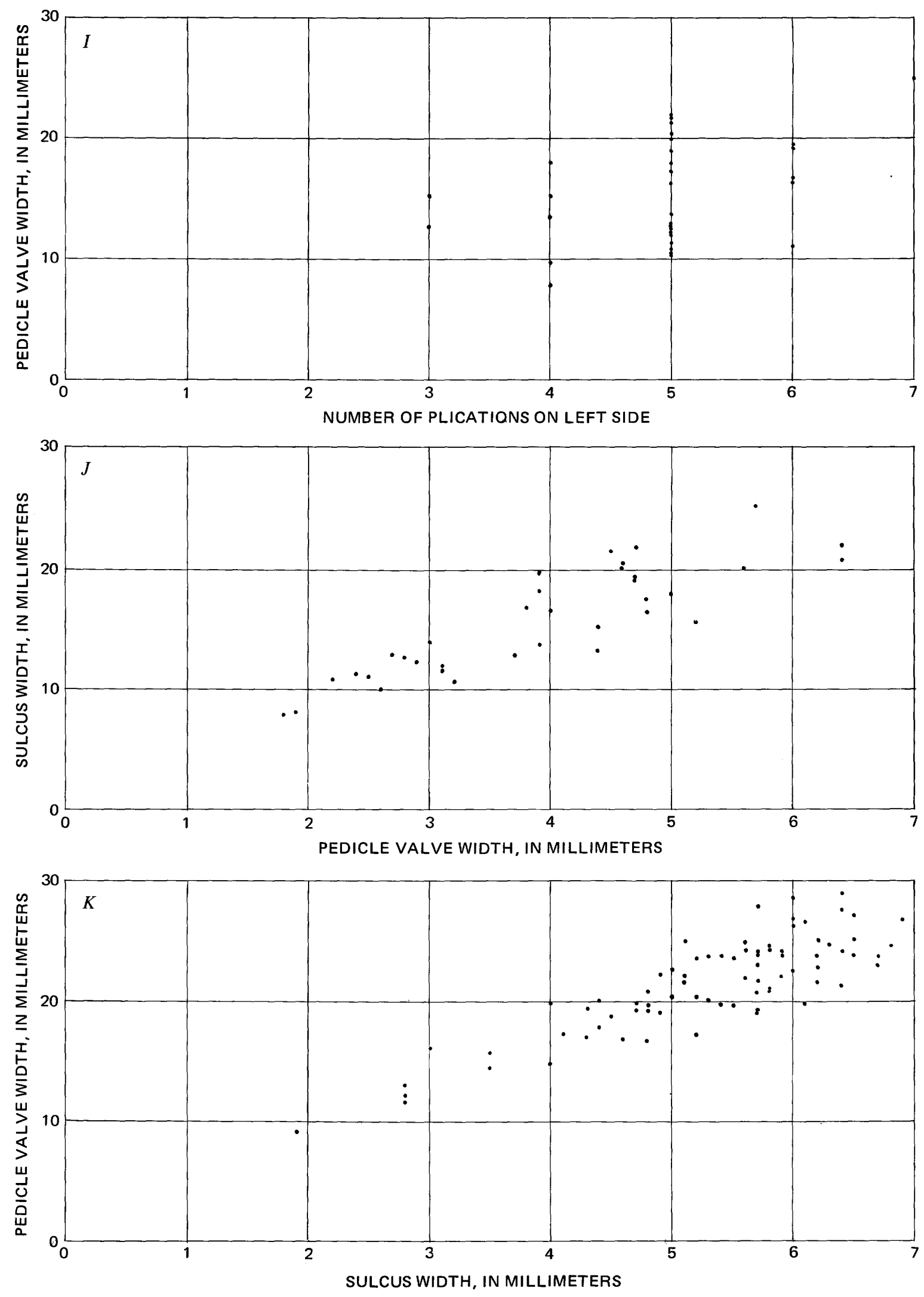

FIGURE 18.-Continued.

$I$, pedicle valve width versus number of plications on left side; USGS loc. 2721-SD. $J$, pedicle valve width versus sulcus width; USGS loc. 2721-SD. $K$, pedicle valve width versus sulcus width; USGS loc. 2720-SD. (Continued on following page). 

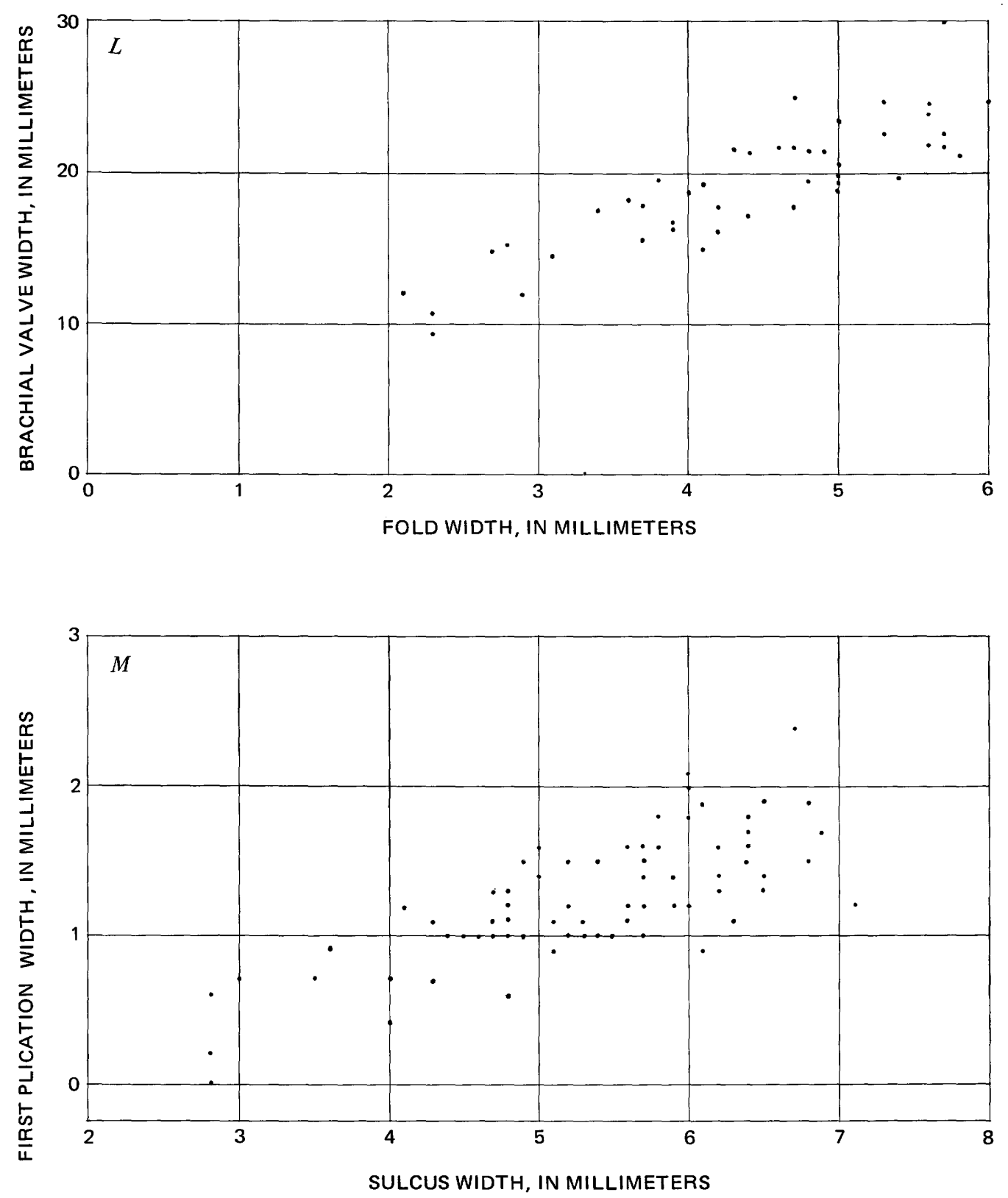

FIGURE 18.-Continued.

$L$, width of brachial valve versus width of fold; USGS loc. 2720-SD. $M$, width of sulcus versus width of first plication on pedicle valve; USGS loc. 2720-SD. (Continued on following page). 

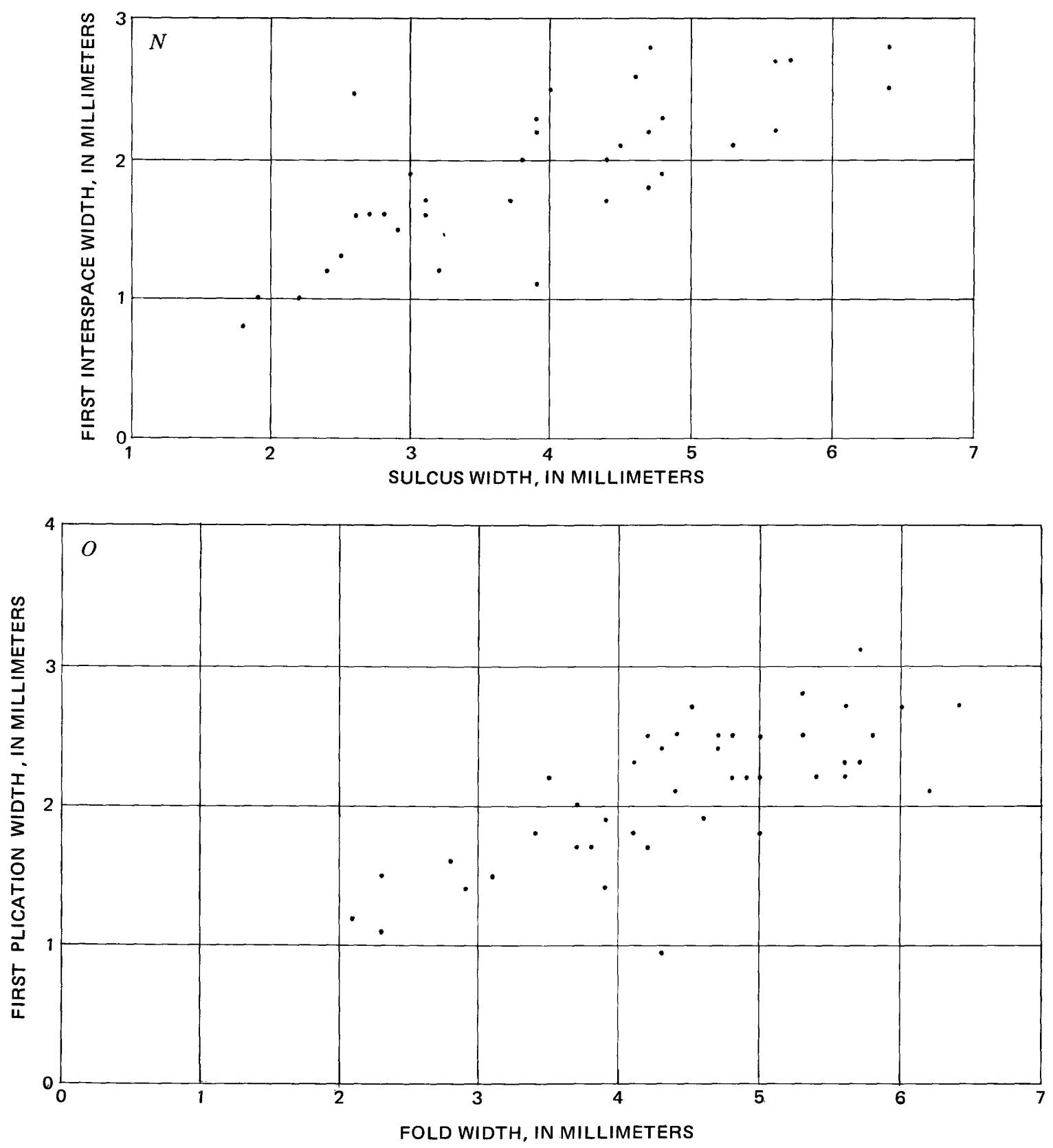

Figure 18.-Continued.

$N$, width of sulcus versus first interspace width; USGS loc. 2721-SD. $O$, width of fold versus width of first plication on brachial valve; USGS loc. 2720-SD. (Continued on following page). 

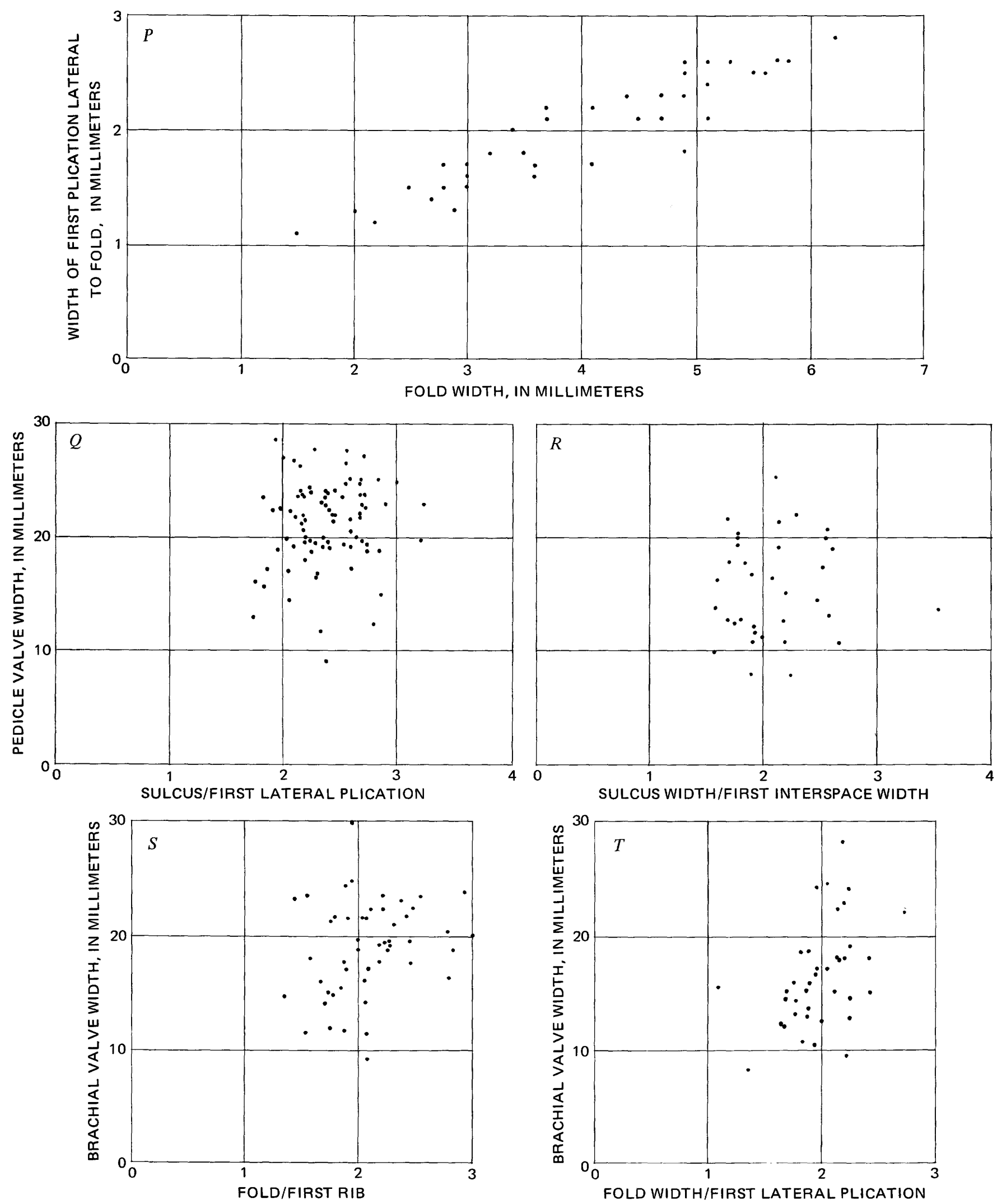

Figure 18.-Continued.

$P$, width of fold on brachial valve versus width of first plication lateral to fold; USGS loc. $2721-S D$. $Q$, pedicle valve width versus ratio of sulcus/first lateral plication width. $R$, pedicle valve width versus ratio of sulcus width/first interspace width; USGS loc. 2721-SD. $S$, brachial valve width versus ratio of fold/first rib; USGS loc. 2720-SD. $T$, width of valve versus ratio of fold width/first lateral plication; USGS loc. 2721-SD. (Continued on following page). 

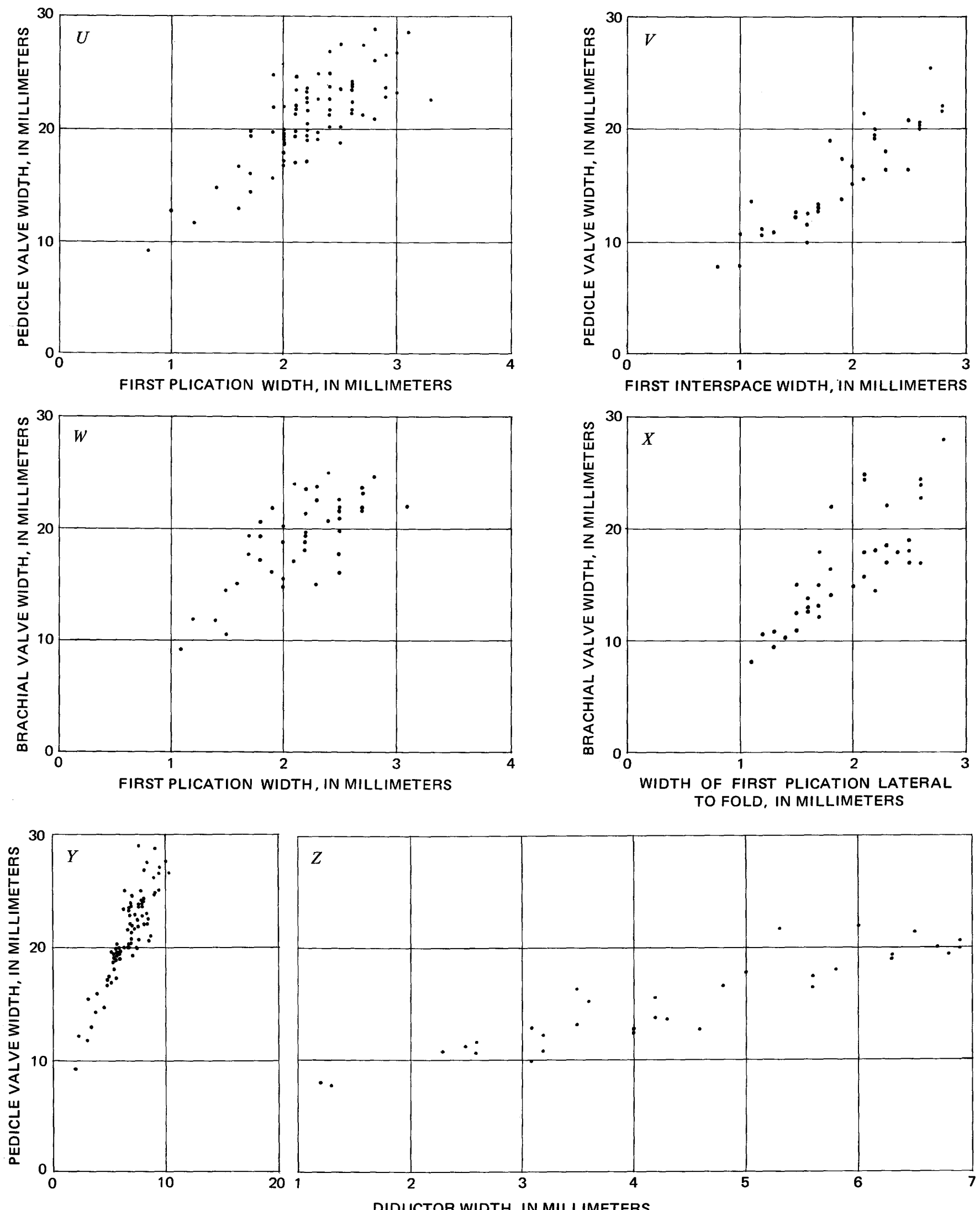

DIDUCTOR WIDTH, IN MILLIMETERS

FIGURE 18.-Continued.

$U$, pedicle valve width versus width of first plication; USGS loc. 2720-SD. $V$, width of pedicle valve versus width of first interspace; USGS loc. 2721-SD. $W$, width of brachial valve versus width of first plication; USGS loc. 2720-SD. $X$, width of brachial valve versus width of first plication lateral to fold; USGS loc. 2721-SD. $Y$, pedicle valve width versus diductor width; USGS loc. 2720-SD. $Z$, width of pedicle valve versus width of diductor; USGS loc. 2721-SD. (Continued on following page). 
Figure 18.-Continued.

$A A$, diductor length versus diductor width of pedicle valve; USGS loc. 2720-SD. $B B$, (below) diductor length versus diductor width on pedicle valve; USGS loc. 2721-SD.
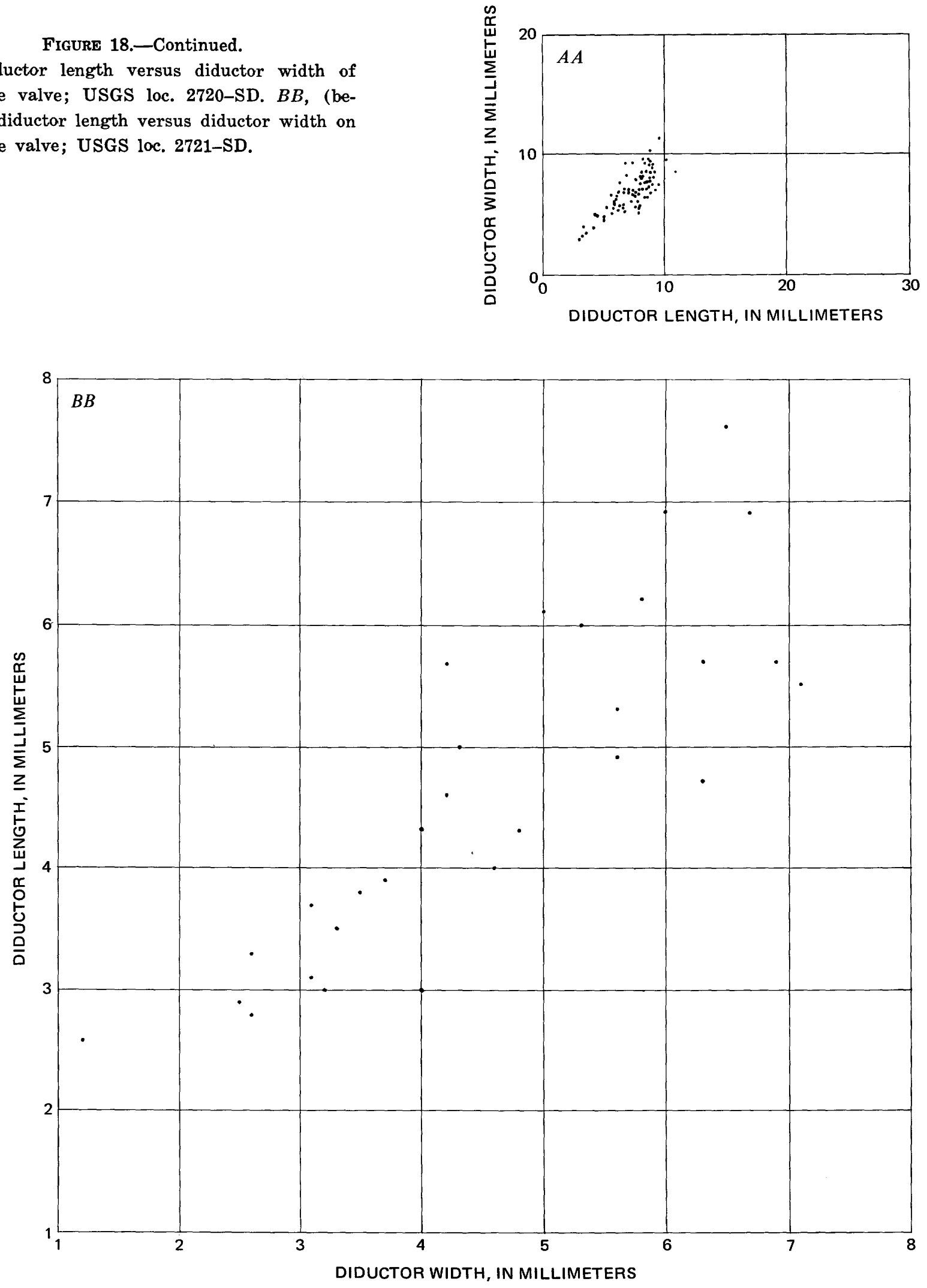

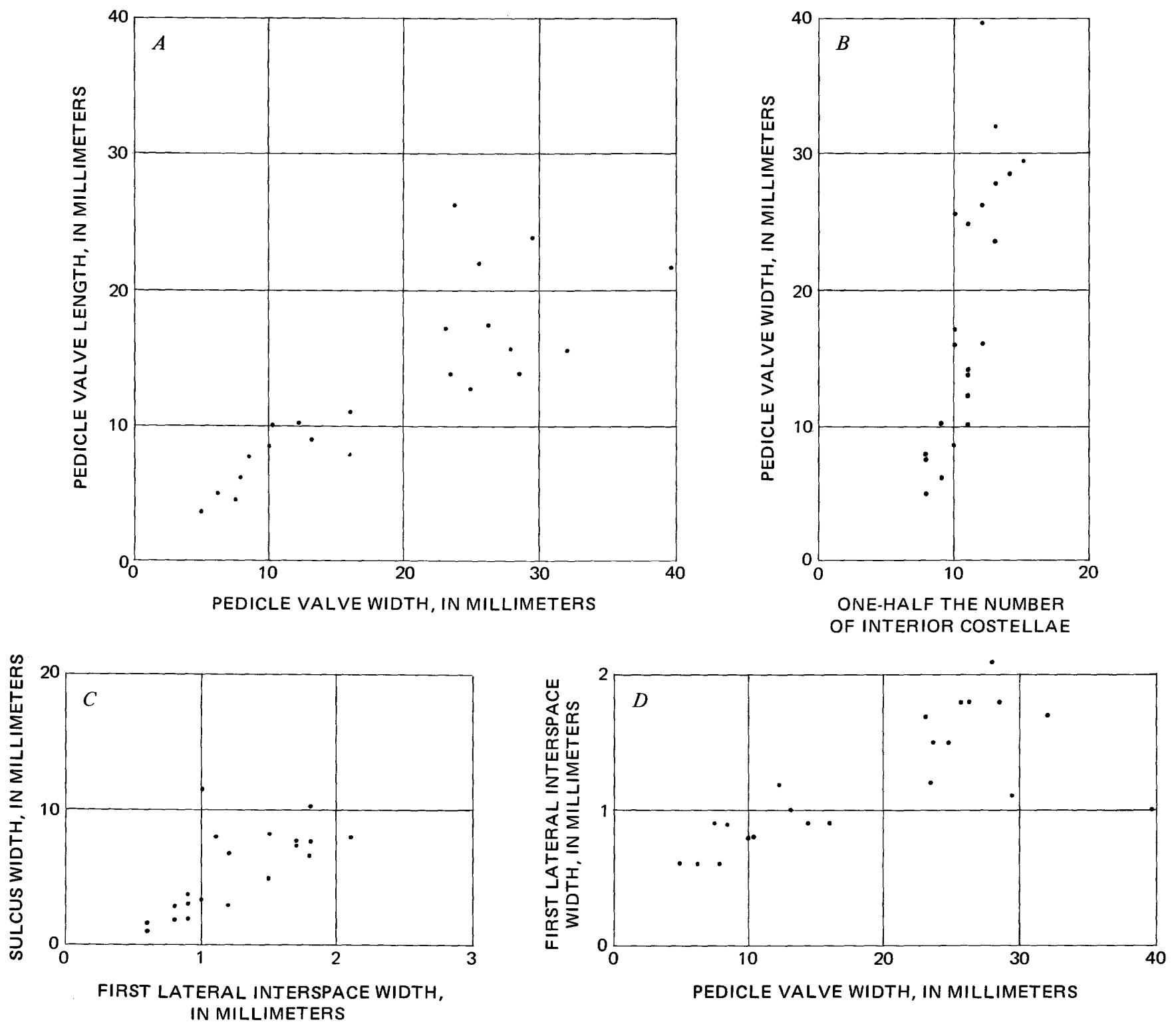

FIGURE 19.-Measurements of Costellispirifer perimele (Clarke, 1907). Tomhegan Formation, USGS loc. 2750-SD, Brassua Lake quadrangle, Somerset County, Maine.

quate comparative material is available to make comparison possible.

"Spirifer" cumberlandiae (Hall, 1857) has a longer ventral interarea, tends to be orthocline, brachial valve has narrow chilidial plates; these characters are absent in "S." perimele.

Occurrence.-USGS locs. 2873-SD, 2750-SD, 2820-SD, 2730-SD, Brassua Lake quadrangle, Somerset County, Maine.

Stratigraphic location.-Tomhegan Formation.

Distribution.-Northern Maine, possibly northern New Hampshire (Boucot and Arndt, 1960) and southeastern New York (Boucot, 1959b).
Figured specimens.-USNM 126035, 126030, 126037, 126029.

Measured specimens.-USNM 125888.

Unfigured specimens.-USNM 126580.

Subfamily MUCROSPIRIFERINAE Genus MUCROSPIRIFER Grabau, 1931 "Mucrospirifer" cf. "M." macra (Hall, 1857)

Plate 18, figures 21, 22

Exterior.-Single pedicle valve internal mold available. Transverse, triangular outline, about twice as broad as long. Lateral profile deeply convex, with flat catacline interarea, giving shell subpyramidal shape. Few poorly preserved radial plica- 

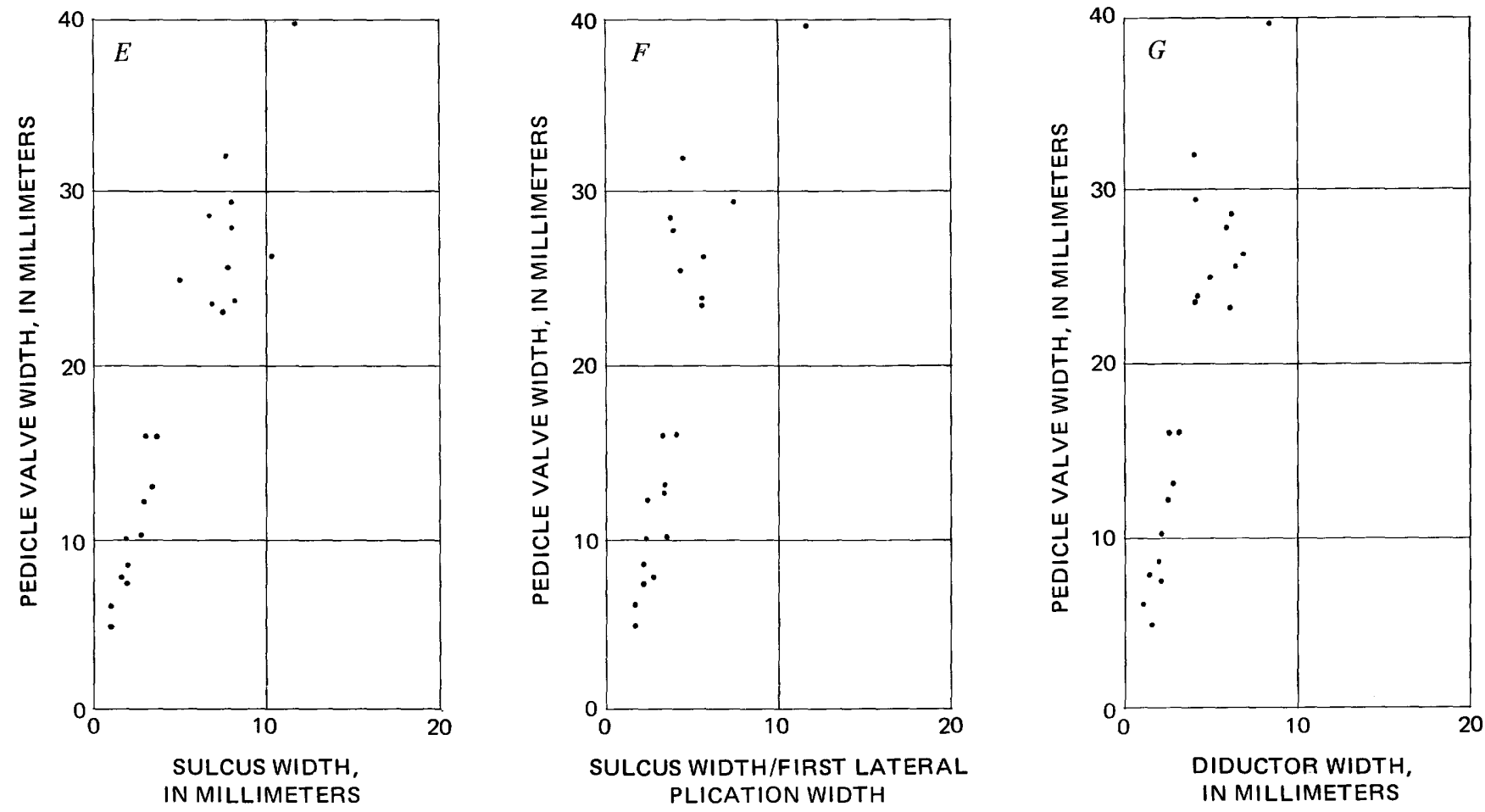

Figure 19.-Continued.

tions seen impressed on interior. Specimen too poorly preserved to describe further external details.

Interior.-Pair thin, platelike dental lamellae are closely spaced and slightly divergent in apex of valve.

Occurrene.-USGS loc. 2723-SD, Somerset County, Maine.

Stratigraphic location. - Tomhegan Formation (Lower Devonian).

Figured specimen.-USNM 160135.

\section{Subfamily COSTISPIRIFERINAE Termier and Termier, 1949 Genus COSTISPIRIFER Cooper, 1942 \\ Costispirifer sp.}

Plate 18, figures 23-26

Exterior.-Unequally biconvex shells, pedicle valve having greater degree convexity than brachial valve. Greatest width at straight hinge line. Subcircular outline. Brachial valve bears low, rounded fold; pedicle valve has corresponding sulcus. Rounded costellae separated by relatively narrow interspaces. Anterior and lateral margins rounded. Anterior commissure uniplicate, crenulate. Pedicle valve interarea gently apsacline, brachial valve interarea steeply anacline. Fold and sulcus costellate. Pedicle valve interarea relatively long, brachial valve interarea steeply anacline. Fold and sulcus costellate. Pedicle valve interarea relatively long, brachial valve interarea short. Delthyrium appears unmodified, includes angle of about $90^{\circ}$.

Pedicle valve interior.-Dental lamellae short, almost obsolete due to deposition of secondary material in umbonal cavities. Dental lamellae convex medially, support stubby hinge teetb located on upper margins delthyrium. Muscle field deeply impressed, subcircular outline. Muscle field restricted posterior half valve, consists of paired, elongate, median adductor impressions longitudinally striate and laterally bounded by paired, anteriorly expanding diductor impressions. Diductor impressions extend posteriorly into pair of pits developed in secondary material lining delthyrial cavity. Anterior and medial to posterior end of diductor impressions is vertical, diamond-shaped, small pedicle callist. Peripheral regions crenulated by impress external ornamentation.

Brachial valve interior.-Small ctenophoridium laterally bounded by socket plates which diverge anterolaterally. Basal part of socket plates not supported by crural plates. Interior crenulated by impress of external ornamentation.

Comparison.-Maine specimens not specifically identifiable. Much of the material has been badly abraded and the external ornamentation removed.

Occurrence.-USGS locs. 3088-SD, 2767-SD, 
3482-SD, Somerset and Piscataquis Counties, Maine.

Stratigraphic location.-Lower sandstone of the Tarratine Formation (Lower Devonian) and Seboomook Formation (Lower Devonian).

Figured specimens.-USNM 126018, 126023.

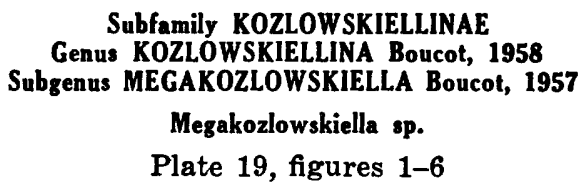

Discussion.-Poor specimens of Megakozlowskiella were obtained at several localities in Somerset County; the material is unfit for specific identification. Specimens from the Beck Pond Limestone have steeply apsacline to catacline pedicle valve interarea and pseudospondylium formed by deposition of secondary material between converging dental lamellae and median septum; in these regards resemble $M$. cyrtinoides.

Occurrence.-USGS locs. 3477-SD, 3499-SD, 3601-SD, 3487-SD, 3497-SD, Spencer Lake and Pierce Pond quadrangles, Somerset County, Maine. Stratigraphic location.-Beck Pond Limestone (Lower Devonian) and Parker Bog Formation (Lower Devonian).

Figured specimens.-USNM 126046, 126044.

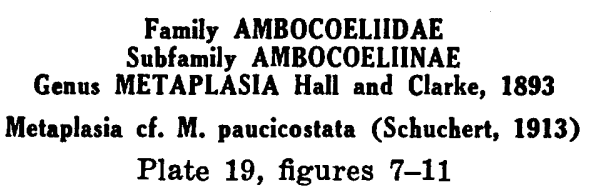

Exterior.-Unequally convex shells, gently convex brachial valve, subconical pedicle valve. Outline subcircular to transversely elliptical, brachial valve more elliptical than pedicle valve. Pedicle valve interarea orthocline or gently apsacline or even gently anacline, beak gently incurved. Hinge line straight, greatest width near midlength. Delthyrium appears unmodified, includes angle of about $60^{\circ}$ Cardinal margins terebratulid; lateral and anterior margins rounded. Shells appear smooth except for concentric growth lines. Pedicle valve bears very shallow median furrow flanked by pair ill-defined plications; remainder valve smooth. Anterior commissure probably feebly intraplicate.

Pedicle valve interior. - Inner margins hinge line flanked by stubby hinge teeth. Muscle field deeply impressed into secondary material lining delthyrial cavity. Muscle field longitudinally elongate in form, consists paired, median adductor impressions separated by myophragm, laterally flanked by pair narrow diductor impressions. Posterior part delthyrial cavity filled by pad secondary material forming me- dially grooved step, may have served as pedicle callist. Umbonal cavities pitted. Pair subparallel pallial trunks appear to extend from anterior portion muscle field almost to anterior margin.

Brachial valve interior.-Small bladelike cardinal process laterally flanked by pair elongate crural plates forms pseudocruralium in posterior part of valve. Well-impressed adductor field anterior of cardinalia is difficult to study on the one specimen available. Valve interior appears smooth.

Comparison.-Maine specimens appear conspecific with Metaplasia pauciocostata from Shriver Chert; the lack of adequate comparative material makes positive specific assignment ill advised. $M$. paucicostata may be subjective synonym $M$. pyxidata; the lack of verified specimens of latter leaves this point in doubt.

Occurrence.-USGS loc. 2806-SD, Pierce Pond quadrangle, Somerset County, Maine.

Stratigraphic location.-McKenney Ponds Member of Tarratine Formation (Lower Devonian).

Figured specimens.-USNM 126115A,B,C.

Unfigured specimens.-USNM 126258.

\section{Metaplasia minuta Boucot, 1959 \\ Plate 19, figures 12-18}

Metaplasia minuta Boucot, 1959a, p. 17-18, pl. 2, figs. 18-24.

Exterior.-Unequally biconvex shells, brachial valve gently convex, pedicle valve subconical. Hinge lineline straight, maximum width located about onethird distance anterior from posterior margin. Valves subcircular to transversely elliptical in outline. Brachial valve bears very low median fold flanked by two pairs very low and distinct costae. Pedicle valve bears low median furrow flanked by one pair prominent costae. Valve surface smooth except for concentric growth lines. Pedicle valve interarea steeply apsacline to catacline, beak incurved gently. Delthyrium open, includes angle of about $30^{\circ}$. Brachial valve interarea very short, appears orthocline, pedicle valve interarea very long. Anterior commissure faintly intraplicate. Anterior and lateral margins rounded.

Pedicle valve interior.-Pair stubby hinge teeth border sides of delthyrium, tracks leave pair of ridges on interior simulating pair short dental lamellae. Low myophragm divides weakly impressed muscle field into pair elongate impressions. Valve interior impressed by plications.

Brachial valve interior.-Short, bladelike cardinal process flanked by crural plates reaching floor of valve, form pseudocruralium. Dental sockets floored by socket plates which posteriorly unite with crural plates. Muscle field weakly impressed, consists of 
elongate median adductor impression laterally bounded by pair elongate, lateral adductor impressions.

Comparison.-Maine material appears specifically distinct from $M$. pauciocostata which it closely resembles. Same form occurs in Camden Chert of Tennessee, but collections of U.S. National Museum do not have enough specimens of this species to permit a thorough comparison. Plications in this material are much stronger than in that from the strata of Oriskany age which has been previously assigned to Metaplasia.

Occurrence.-USGS loc. 2750-SD, 2852-SD, 2820SD, Brassua Lake quadrangle, Somerset County, Maine.

Stratigraphic location.-Tomhegan Formation (Lower Devonian).

Figured specimens.-USNM 126086, 126110, 126067.

Unfigured specimens._USNM 126597-126600.

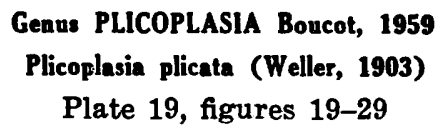

Plicoplasia plicata (Weller, 1903), see Boucot, 1959a, p. 22, pl. 1, figs. 1-9.

Exterior.-Unequally biconvex shells. brachial valve gently convex, pedicle valve subconical. Greatest width at straight hinge line, or at position slightly anterior. Transversely elliptical outline. Brachial valve bears broad, shallow medial medial sulcus, pedicle valve bears broad, low median fold. Anterior commissure weakly sulcate, crenulate. Posterior part lateral margin straight, remainder and anterior margin, rounded. Plications rounded cross section, separated by wide, U-shaped interspaces. One plication situated in sulcus, each flank bears three to four plications including one bounding fold or sulcus laterally. Plications bounding fold larger than remainder present on shell. Pedicle valve interarea orthocline to gently apsacline, beak straight to gently incurved. Pedicle valve interarea relatively long, brachial valve interarea short. Brachial valve interarea orthocline to gently anacline. Concentric growth lines relatively lamellose anteriorly. Delthyrium open, includes angle of about $30^{\circ}$.

Pedicle valve interior. - Stout hinge teeth situated either side hinge line's median edge. Hinge tooth track buried in secondary material deposited against posterior valve wall. Myophragm bisects muscle field, extends anteriorly to about midlength. Muscle field weakly discernible. Interior crenulated by plication impress.

Brachial valve interior.-Prostrate, posteriorly directed, medially grooved, terminally bifid cardinal process laterally flanked by basomedially converging crural plates whose lower edges are parallel. Dental sockets formed medially by crural plates, anterolaterally by socket plates which bottom them, posteriorly by interarea. Dental sockets triangular in cross section. Myophragm bisects valve, muscle field unimpressed. Valve interior crenulated by impress external ornamentation.

Comparison. $-P$. plicata has a shallower sulcus and lower fold than $P$. cooperi. $P$. plicata tends to have more lateral costae than $P$. cooperi.

Occurrence.-USGS locs. 2813-SD. 2811-SD, 2798-SD, 2797-SD, 3089-SD, and questionably 3481-SD, 2735-SD, 2731-SD, 3482-SD, 2884-SD, Somerset and Piscataquis Counties, Maine.

Stratigraphic location.-Lower sandstone of the Tarratine Formation (Lower Devonian), and the Seboomook Formation (Lower Devonian).

Distribution.-Eastern North America.

Figured specimens.-USNM 126114, 126087, 126106, 126256, 126259, 126260.

$$
\begin{gathered}
\text { Superfamily CYRTINACEA } \\
\text { Family CYRTINIDAE } \\
\text { Subfamily CYRTININAE } \\
\text { Genus CYRTINA Davidson, 1858 } \\
\text { Cyrtina? cf. C. rostrata (Hall, 1857) } \\
\text { Plate 19, figures 30-32 }
\end{gathered}
$$

Exterior.-Single badly deformed internal mold available. Transverse, subtriangular outline, deeply unequally biconvex lateral profile. Pedicle valve very deep, subpyramidal, with high flat catacline ventral interarea. Narrow median pedicle valve sulcus, corresponding low brachial valve fold. Numerous relatively small radial plications; eight or nine discernible on one valve flank.

Pedicle valve interior.-Specimen too poorly preserved to be certain of internal features; appears to be median groove or line of demarcation that may have accommodated ventral median septum.

Brachial valve interior.-Internal structures too poorly preserved to afford description. Interior corrugated by impress of radial plications.

Occurrence.-USGS loc. 2883-SD. Spencer Lake quadrangle, Somerset County, Maine.

Stratigraphic location. - Seboomook Formation (Lower Devonian).

Figured specimen.-USNM 160136.

$$
\begin{gathered}
\text { Suborder ATHYRIDOIDEA } \\
\text { Superfamily ATHYRIDACEA } \\
\text { Family MERISTELLIDAE } \\
\text { Subfamily MERISTINAE } \\
\text { Genus MERISTA Suess, } 1851
\end{gathered}
$$

Merista cf. M. tennesseensis Hall and Clarke, 1895

Plate 20, figures 1-6

Exterior.-Subequally convex shells with longitudinally elongate, elliptical outline. Maximum 
width near midlength. Cardinal margins pedicle valve terebratulid, beak incurved over posterior end brachial valve. Lateral and anterior margins rounded. Brachial valve bears low broad fold, originating about midlength, pedicle valve bears broad shallow sulcus originating in anterior quarter of shell. Anterior commissure uniplicate. Concentric growth lines.

Pedicle valve interior.-Well-developed shoe-lifter process. Short dental lamellae bound delthyrial cavity.

Brachial valve interior.-Short septalium supported by median septum which extends anteriorly to about midlength.

Comparison.-Maine material resembles $M$. tennesseensis in external form but is inadequate for a positive specific identification.

Occurrence.-USGS loc. 3488-SD, Spencer Lake quadrangle, Somerset County, Maine.

Stratigraphic location.-Hardwood Mountain Formation (Upper Silurian).

Figured specimens.-USNM 126105, 126085.

Subfamily MERISTELLINAE
Genus MERISTELLA Hall, 1860
Meristella lata (Hall, 1859)
Plate 20, figures 7-13

Meristella lata (Hall, 1859), see Clarke, 1900 p. 45.

Exterior.-Unequally convex shells, brachial valve having greater degree convexity than pedicle valve. Shell outline subcircular to longitudinally elliptical. Pedicle valve cardinal margins terebratuloid. Lateral, anterior margins rounded. Brachial valve bears low fold originating near midlength. The greatest width located slightly posterior to midlength. Pedicle valve bears broad shallow sulcus. Anterior commissure uniplicate. Concentric growth lines.

Pedicle valve interior.-Short, obsolete dental lamellae border delthyrial cavity, support stout hinge teeth. Umbonal cavities filled with secondary material. Muscle field deeply impressed into secondary material lining posterior part of valve. Muscle field flabellate, outline subtriangular, extends anteriorly to about three-quarters distance to anterior margin, about half as wide as valve. Muscle field longitudinally striate. Posterior part delthyrial cavity filled with secondary material into which is indented a spherical chamber serving as pedicle callist.

Brachial valve interior.-Cardinal plate appears formed from medially conjunct hinge plates, basally supported by medial septum which extends anteriorly three-quarters distance to anterior margin. Median part cardinal plate depressed. Spires laterally directed, nature of jugum not ascertained. Spire contains about 13 whorls. Dental sockets anteriorly directed, partly roofed over by projecting edges of cardinal plate. Muscle field unimpressed.

Occurrence.-USGS locs. 2810-SD, 2806-SD, 3089-SD, 2732-SD, 2731-SD, 2722-SD, 2813-SD, 2776-SD, 3482-SD, 2720-SD, 2777-SD, 2797-SD, 2719-SD, 2847-SD, 2760-SD, 2798-SD, 2767-SD, 2701-SD, 2884-SD, 2770-SD, 2729-SD, 2861-SD, 2721-SD, 2771-SD, Somerset and Piscataquis Counties, Maine.

Stratigraphic location.-McKenney Ponds Member and upper and lower sandstones of the Tarratine Formation (Lower Devonian), Seboomook Formation (Lower Devonian).

Figured specimens._USNM 126103, 126116A, 126079, 126082, 126261, 127390.

Unfigured specimens._USNM 126104, 126469, 126581-126596.

\section{Meristella? sp.}

Discussion.-Inadequate material of a rostrospiroid that resembles Meristella was obtained at several localities in strata of pre-Oriskany age.

Occurrence.-Localities 3499-SD, 3487-SD, 3477SD, Pierce Pond and Spencer Lake quadrangles, Somerset County, Maine.

Stratigraphic location.-Parker Bog Formation (Lower Devonian) and Beck Pond Limestone (Lower Devonian).

Unfigured specimens.-USNM 126569-126577.

Genus CHARIONOIDES Boucot, Johnson and Staton, 1964

Charionoides doris (Hall, 1860)

Plate 20, figures 14-22

Charionoides doris (Hall, 1860), see Boucot, Johnson, and Staton, 1964, p. 817-818, pl. 127, figs. 14-20.

Exterior.-Subequally biconvex shells, pedicle valve more convex than gently convex brachial valve. Almond-shaped shell outline, maximum width about two-thirds distance from posterior. Cardinal margins terebratulid; palintrope elongate, slightly concave. Ventral beak very attenuate. Anterior and lateral margins rounded. Concentric growth lines. Neither fold nor sulcus present. Delthyrium appears closed by pair small plates, except for small mesothyrid foramen.

Pedicle valve interior.-Short dental lamellae laterally bound delthyrial cavity. Muscle field weakly impressed in small specimens, in large specimens deeply impressed and flabellate. Muscle field subtriangular impression deeply impressed posteriorly, probably represents diductor impressions, posterior of which are small elongate adductor impressions. Pedicle callist located in posterior part delthyrial cavity.

Brachial valve interior.-Sessile cruralium formed 
from medially conjunct hinge plates supported by low median septum. Brachiophores extend from upper parts hinge plates. Median septum bisects cruralium base as low ridge.

Occurrence.-USGS locs. 2750-SD, 2820-SD, Brassua Lake quadrangle, Somerset County, Maine.

Stratigraphic location. - Tomhegan Formation (Lower Devonian).

Figured specimens. - USNM 126111B, 126092, 126102, 126081, 126080A, 126117.

\section{Family NUCLEOSPIRIDAE \\ Genus NÚCLEOSPIRA Hall, 1859 \\ Nucleospira sp. \\ Plate 20, figures 23-27}

Exterior.-Unequally convex shells, pedicle valve having greater degree convexity than brachial valve. Shell outline subcircular, greatest width near midlength. Cardinal margins pedicle valve terebratulid. Pedicle valve bears shallow, narrow sulcus. Concentric growth lines. Lateral and anterior margins rounded. Peripheral region bears series of fine spines. Delthyrium unmodified, includes angle of about $90^{\circ}$.

Pedicle valve interior.-Short tooth tracks border delthyrial cavity, support small, stubby hinge teeth. Low median septum extends anteriorly to about valve midlength. Muscle field unimpressed. Anterior of valve smooth.

Brachial valve interior.-Platelike cardinal process posteriorly reflexed, supported anteriorly by short median septum. Narrow adductor impressions either side median septum. Anterior of valve is smooth.

Comparison.-Material is inadequate for specific identification.

Occurrence.-USGS loc. 3479-SD, Spencer Lake quadrangle, Somerset County, Maine.

Stratigraphic location.-Base of Hobbstown Formation (Upper Silurian).

Figured specimens.-USNM 126091, 126262.

Family ATHYRIDIDAE

Subfamily ATHYRIDINAE

Genus PROTATHYRIS Kozlowski, 1929

Protathyris sp.

Plate 20, figures 28-37; figure 20

Exterior.-Shells biconvex, pedicle valve having greater degree convexity. Shell outline subcircular transversely elliptical. Hinge line curved, much shorter than maximum width located near midlength. Pedicle valve beak gently incurved, interarea steeply apsacline to catacline. Pedicle valve interarea relatively long, brachial valve interarea short. Brachial valve bears broad low fold, pedicle valve has corresponding sulcus. Anterior commissure uniplicate. Concentric growth lines.
Pedicle valve interior.-Short dental lamellae laterally bound delthyrial cavity (fig. 20), posteriorly support bladelike, medially directed hinge teeth. Muscle field weakly impressed, but appears to consist of elongate muscle field medially divided by low broad median septum. Delthyrium not modified.

Brachial valve interior.-Cardinal plate formed from medially conjunct hinge plates, medial trough. Brachiophores attached to lateral portions cardinal plate. Cardinal plate laterally overlaps anteriorly directed dental sockets. Spire present.

Comparison.-Adequate material is unavailable for making specific assignment. The chief differences (with the possible exception of the spiralia and jugum, which were not studied) between the related genera Greenfieldia and Protathyris are the relative degree of valve convexity and the inclination of the ventral interarea. Protathyris has a steeply inclined interarea which may be catacline; Greenfieldia has a gently apsacline to orthocline ventral interarea. Protathyris has a more inflated and gibbous aspect than does Greenfieldia.

Occurrence.-USGS loc. 2822-SD, Attean quadrangle, Somerset County, Maine.

Stratigraphic location. - Hardwood Mountain Formation (Upper Silurian).

Figured specimens.-USNM 126070, 126262.

Unfigured specimens.-USNM 126059, 126071.

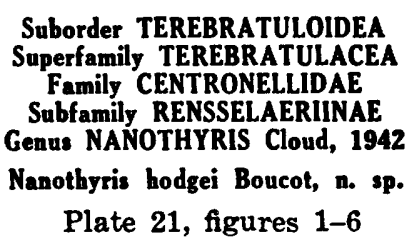

Exterior.-Shell biconvex, brachial valve gently convex, pedicle valve more strongly convex, slightly subcarinate form. Shells small. Valves longitudinally elongate, subcircular to elliptical outline. Greatest width located near midlength. Maximum thickness located about one-third to one-half distance anterior from beak. Anterior margin rectimarginate, faintly crenulate. Cardinal margins subterebratulid. Hinge line straight. Pedicle valve beak erect to suberect. Planarea one-half to two-thirds as wide as maximum width. Umbonal regions smooth, peripheral regions faintly costellate. Costellae low, rounded cross section separated by rounded interspaces. Shell thin.

Pedicle valve interior.-Dental lamellae thin, extend anteriorly about one-fifth maximum length. Muscle field feebly impressed. Muscle field appears to consist of elongate diductor field medially enclosing small, elliptical adductor impression.

Brachial valve interior.-Concave cardinal plate posteriorly perforate, free, supported basally by dis- 
crete crural plates. Dental sockets narrow, short, make angle of about $45^{\circ}$ with hinge line. Muscle field weakly impressed, medially divided by low myophragm. Narrow, elongate, paired lateral adductors slightly impressed posteriorly, enclose medial adductor.

Measurements. - Relationships among length, width, and thickness are linear (fig. 21) with a relatively high degree of dispersion, reflecting the limited size range of the sample.

Comparison. - N. hodgei is distinct from N. mutabilis. The former has a weaker impress of the costellae, less terebratulid outline of cardinal margin, and less gibbous lateral aspect. $N$. hodgei differs from $N$. subglobosa in its less gibbous lateral aspect much less strongly impressed ornamentation, less terebratulid cardinal margins, and more erect beak. $N$. reesidei has more strongly impressed ornamentation, more terebratulid cardinal margins, and a slightly more gibbous profile. $N$. hodgei differs from $N$. subglobosa crassa and N. subglobosa avus in its less well impressed radial ornamentation; its outline less circular than that of $N$. subglobosa crassa.

Occurrence. - USGS locs. 2832-SD, 2890-SD, 2721-SD, 3090-SD, Somerset County, Maine.

Stratigraphic location.-Tarratine Formation.

Distribution.-Somerset County, Maine.

Holotype.-USNM 126194.

Measured paratypes.-USNM 125940.

Figured paratypes. - USNM 126191, 126220, $126183,125943$.

Unfigured paratypes.-USNM 125941, 125942, $125944,125945$.

Nanothyris cf. N. subglobosa (Weller, 1903)

Plate 21, figures 7-13

Exterior.-Shell biconvex, gently convex brachial valve, more highly convex, carinate pedicle valve. Pedicle valve about $11 / 2$ times as deep as brachial valve. Shells elongate, elliptical outline. Maximum width situated near midlength or slightly posterior. Lateral and anterior margins rounded. Anterior margin rectimarginate, weakly crenulate. Weak costellae distributed about periphery, absent in umbonal regions. Cardinal margins subterebratulid. Hinge line short, rounded. Pedicle valve beak appears suberect.

Pedicle valve interior.-Dental lamellae thin, short. Muscle field very weakly impressed.

Brachial valve interior.-Serial sections demonstrate presence of cardinal plate supported by crural plates, posteriorly perforate.
Comparison.-These specimens most closely resemble N. subglobosa but the deformed state of available material precludes positive specific identification.

Occurrence.-USGS locs. 3601-SD, 3600-SD, Spencer Lake quadrangle, Somerset County, Maine.

Stratigraphic location.-Beck Pond Formation (Lower Devonian).

Figured specimens.-USNM 126187, 126192 A, B.

\section{Genus RENSSELAERIA Hall, 1859 \\ Rensselaeria sp. \\ Plate 21, figures 14-17}

Exterior.-Fragmentary exteriors present are badly abraded. Pedicle foramen appears submesothyrid. Cardinal margins terebratulid. Pedicle valve beak nearly straight. Pedicle valve more strongly convex than brachial valve. Lateral margins rounded, anterior margins appear rounded.

Pedicle valve interior.-Dental lamellae short, almost entirely obsolete due to deposition secondary material in umbonal cavities. Hinge teeth bladelike, inclined basally towards midline. Hinge teeth fused basally with dental lamellae. Muscle field deeply impressed, consists of elongate diductor field with subparallel sides, posteriorly divided by myophragm along which were probably very narrow adductor impressions. Secondary material almost fills posterior part of delthyrial cavity, except for deeply impressed muscle field. Upper surface of secondary material bears pedicle callist.

Brachial valve interior. - Thickened cardinal plate, posteriorly perforate, supported by pair crural plates. Dental sockets narrow, laterally directed. Muscle field weakly impressed, consists of two pairs elongate subparallel adductor impressions. Low myophragm medially divides muscle field.

Comparison.-Maine material too poor to be specifically identified.

Discussion.-In regard to the stratigraphic range of the genus, Cloud (1942, p. 47) assigned "Atrypa" aequiradiata Conrad, 1842, from the Becraft Limestone, to Nanothyris. Reexamination shows it belongs to Rensselaeria s. s. because of its radially ornamented umbones and internal morphology which differ in no important respect from those of the other species assigned to Rensselaeria by Cloud (1942), p. 55, 56).

Material assigned by Boucot (in Woodard, 1951, p. 76) to "Beachia cf. thunii" belongs to Rensselaeria sp.

FIGURE 20.-Serial sections of specimen of Protathyris sp. $(\times 4.5)$. Hardwood Mountain Formation. USGS loc. 2822-SD, Attean quadrangle, Somerset County, Maine. Numbers are measurements in millimeters from posterior end of shell. 


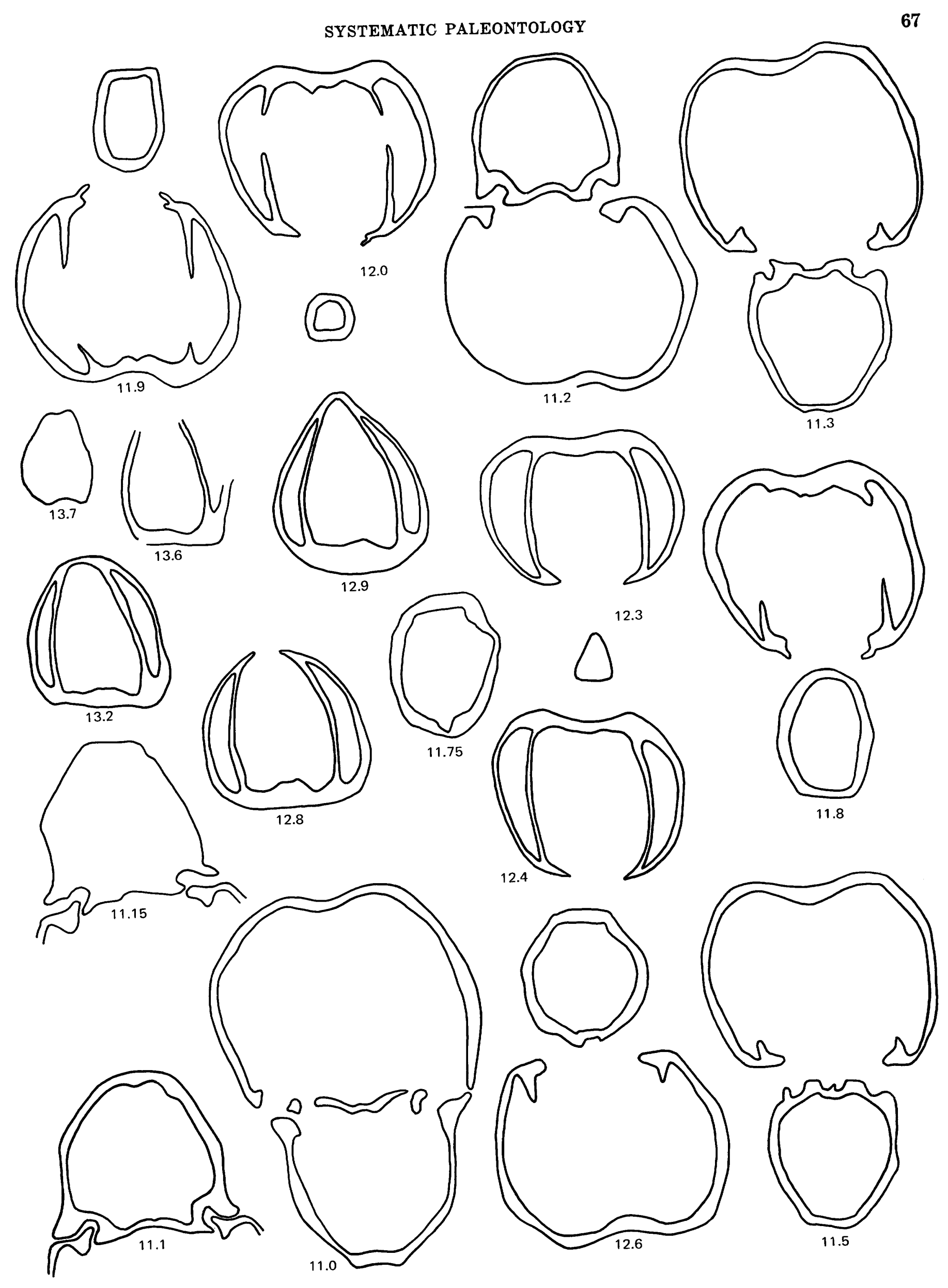



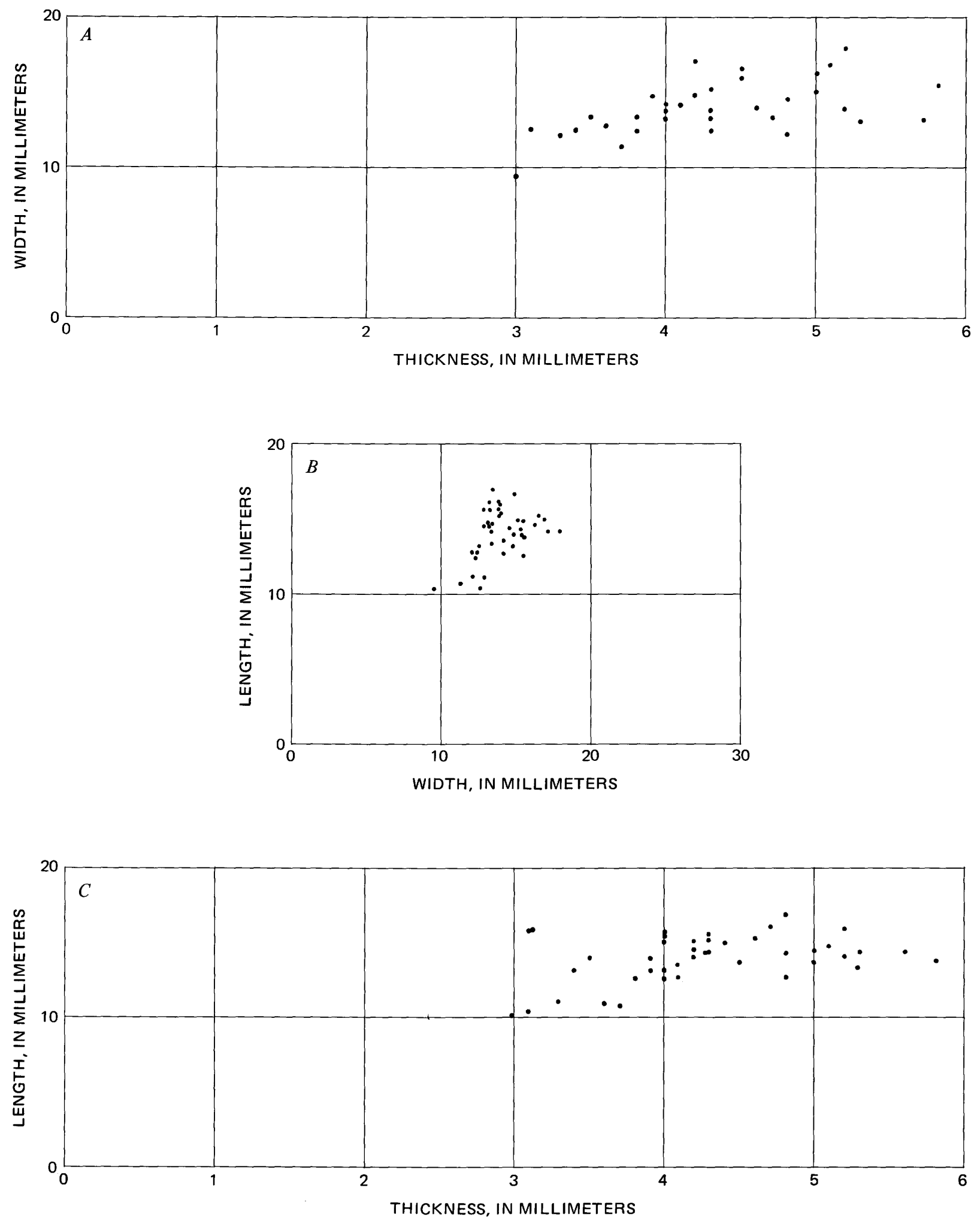

FIGURE 21.-Measurements of pedicle valves of Nanothyris hodgei Boucot, n. sp. Lower sandstone of Tarratine Formation. USGS loc. 3090-SD, Long Pond quadrangle, Somerset, Maine. 
Occurrence.-USGS locs. 2767-SD, 2729-SD, Somerset County, Maine.

Stratigraphic location.-Lower sandstone of the Tarratine Formation (Lower Devonian).

Figured specimens.-USNM 126216, 126214.

Unfigured specimens.-USNM 126215, 126213.

Subfamily EURYTHYRIDINAE

Genus BEACHIA Hall and Clarke, 1893

Beachia thunii (Clarke, 1907)

Plate 21, figures 18-30; plate 22, figures 1-5

Megalanteris thunei (Clarke, 1907), p. 168, pl. 26, figs. 8-13; pl. 27, figs. 7-15.

Exterior.-Shell subequally biconvex, subcarinate pedicle valve having somewhat greater degree convexity than gently convex brachial valve. Shell subcircular. Pedicle foramen mesothyrid. Small deltidial plates medially conjunct. Anterior commissure rectimarginate, feebly crenulate in some specimens. Lateral and anterior margins rounded. Cardinal margin subterebratulid. Concentric growth lines, sometimes faintly impressed costellae, particularly peripherally. Pedicle valve beak suberect. Maximum width located at midlength. Lateral margins may be introverted, but on most specimens this feature not evident.

Pedicle valve interior.-Dental lamellae short, become almost entirely obsolete with increase in specimen size, due to deposition secondary material in umbonal cavities. Anterior part dental lamellae bears bladelike hinge teeth. Inner face each hinge tooth longitudinally grooved to receive lateral margin of cardinal plate. Posterior part delthyrial cavity filled with secondary material except for site of pedicle callist. Diductor field deeply impressed, narrow and straight-sided in form, divided medially in posterior part of valve by low myophragm. Myophragm bordered by pair narrow adductor impressions. Anterior of myophragm is elliptical anterior diductor impression. Interior of valve smooth.

Brachial valve interior.-Cardinalia of small shells consist of discrete hinge plates united anteromedially by narrow band (posterior of band is large, triangular foramen). Under hinge plates are supporting crural plates. Muscle field small shells barely impressed, although myophragm prominent. This stage brachial valve similar to Nanothyris. In large specimens cardinalia consist of cardinal plate bearing ponderous, moundlike thickening which serves as cardinal process. Foramen in cardinal plate closed off as size of cardinal process increases, at same time crural plates become almost entirely submerged in secondary material. Dental sockets deep, anterolaterally directed. Muscle field consists of posteriorly deeply impressed adductor impression divided medially by myophragm. Posteromedial pair adductor impressions can be distinguished from pair of elongate lateral impressions in some shells. Pallial marks extend toward anterior margin from anterior margins of muscle field, subparallel to midline. Brachiophores bladelike.

Comparison.-B. thunii does not possess the prominent, introverted lateral margins of $B$. suessana, as judged from material studied, in addition the latter species seems to possess more consistently costellate ornamentation. Cardinal process of $B$. thunii is commonly swollen and enlarged whereas in $B$. suessana the cardinal plate is not commonly greatly thickened.

Specimen questionably referred to Meganteris by Cloud (1942, p. 109-110) belongs to Beachia thunii.

Occurrence.-USGS locs. 2813-SD, 2700-SD, 2701-SD, 2731-SD, 2729-SD, 2732-SD, 2751-SD, 2792-SD, 2769-SD, 2767-SD, 2776-SD, 2798-SD, 2803-SD, 2812-SD, 2771-SD, 2777-SD, 2725-SD, 2830-SD, 2761-SD, 2810-SD, 3482-SD, 3486-SD, 2806-SD, 2872-SD, 2760-SD, 2870-SD, 3474-SD, 2864-SD, 2796-SD, 2884-SD, Somerset and Piscataquis Counties, Maine.

Stratigraphic location.-Seboomook Formation (Lower Devonian), and McKenney Ponds Member and lower sandstone of the Tarratine Formation (Lower Devonian).

Distribution.-Eastern North America.

Figured specimens. - USNM 126198-126200, 126202-126207, 126209, 127217, and New York State Museum 8436.

Unfigured specimens.-USNM 126177, 126605126608, 126610-126634.

\section{Genus CLOUDOTHYRIS Boucot and Johnson, 1968 \\ Cloudothyris postovalis Boucot and Johnson, 1968}

Plate 22, figures 6-13

Cloudothyris postovalis Boucot and Johnson, 1968, p. B19B20, pl. 7, figs. 26-42.

Exterior.-Shell subequally biconvex, pedicle valve slightly more convex than brachial valve. Shell outline elongate, elliptical. Lateral margins introverted, defining long lateral reentrants which merge posteriorly with planareas. Anterior commissure rectimarginate. Pedicle valve beak short, suberect. Pedicle valve foramen mesothyrid. Deltidial plates, probably present, appear conjunct, small. Beak ridges sharp, define prominent planareas which extend width of posterior margin. Maximum width located about one-third distance anterior from beak. Concentric growth lines.

Pedicle valve interior.-Dental lamellae almost 
obsolete in large specimens due to deposition secondary material in umbonal cavities. Dental lamellae short. Hinge teeth bladelike, supported by dental lamellae. Muscle field elongate, one-quarter to onefifth as wide, and half as long as valve. Long, narrow diductors posteriorly and laterally surround small, elongate, median adductor scar; diductors laterally bounded by elongate, pedicle valve adjustor impressions. Myophragm bisects posterior part muscle field, extends anteriorly to adductor impression. Pedicle callist situated against posterior wall delthyrial cavity.

Brachial valve interior.-Cardinal plate thick, completely sessile, imperforate, supported by crural plates almost entirely submerged in secondary material which fills in space under cardinal plate. Anterior portion each crural plate recognizable in small specimens. Rising vertically from cardinal plate is elongate, terminally bifid cardinal process. Two limbs of cardinal process taper to anteriorly directed tips. Posterior face each limb indented by slits which diverge laterally from base of cardinal process. Lateral sides of slits vertically grooved. Cardinal process of small specimens consists of low, bifid, stumplike structure. Cardinal process covers median half cardinal plate, leaving only lateral parts exposed. Dental sockets located at posterior base cardinal plate, open posteriorly in large specimens, closed posteromedially by convergent outer socket ridges of small specimens. Dental sockets shallow anteriorly, extend medially well under posterior edge of cardinal plate. Muscle field elongate, one-fifth as wide and one-quarter to one-fifth as long as valve. Posterolateral adductor scars sublunate to elongate, deeply impressed posteriorly. Anterior extension posterolateral adductor scars bounds ovate, anteromedial adductor scars. Myophragm well developed in large specimens, extends posteriorly from anteromedial adductor impression to anterior face of cardinal plate. Valve interior smooth.

Occurrence.-USGS locs. 2750-SD, 2814-SD, 2820-SD, 3238-SD, Brassua Lake quadrangle, Somerset County, Maine.

Stratigraphic location.-Tomhegan Formation.

Distribution.-Somerset County, Maine; western New York; and possibly northern New Hampshire (Boucot and Arndt, 1960).

Holotype.-USNM 147299 (Boucot and Johnson, 1968 , pl. 7, figs. 28-33) is herein designated the holotype.

Figured specimens._USNM 126195, 126210A, $126208,126218$.

Unfigured specimens.-USNM 126635-126637.

\section{Subfamily AMPHIGENIINAE Genus AMPHIGENIA Hall, 1867 \\ Amphigenia parva Clarke, 1907 \\ Plate 22, figures 14-24}

Exterior.-Shell unequally biconvex, naviculate pedicle valve about twice as deep as gently convex brachial valve. Shell outline subcircular to elongate, elliptical. Maximum width located one-third to onehalf distance anterior from beak. Anterior commissure rectimarginate. Lateral margins straight to rounded, anterior margin rounded. Hinge line short, rounded. Concentric growth lines, some specimens, faint costellae. Beak region characters similar those described by Cloud $(1942$, p. 78,79$)$ for $A$. elongata.

Pedicle valve interior.-Dental lamellae short, medially convergent to form spondylium basally supported by median septum. Median septum extends to about midlength. Stubby hinge teeth located on posterior margins spondylium. Posteriorly spondylium is laterally buttressed by mystrochial plates. Excavation for pedicle callist located at posterior end delthyrial cavity. Myophragm bisects bottom of spondylium.

Brachial valve interior.-Cardinal plate possesses foramen posteriorly, basally supported by pair crural plates. Cloud (1942, p. 78) mentioned presence of crural plates converging medially about myophragm to form structure resembling cruralium. $A$. curta shows this structure actually formed by deposition of secondary material between crural plates to raise tube connecting foramen from base of shell. This character is one associated with increase in size rather than taxonomic position. Suite of specimens of $A$. parva shows stages having every gradation from ones with no secondary material on valve floor to those with tube elevated and cruralium appearing to be present. Narrow pair posterolateral adductor impressions laterally border elongate medial adductor impressions, bisected by myophragm which extends under cardinal plate. Dental sockets laterally directed, posteriorly border cardinal plate.

Measurements.-Relations between length and width of both pedicle and brachial valves are almost random due to mechanical deformation (figs. $22 A, D)$, plus the fact that the anterior portions of some specimens may have been broken off, plus the indication that this species is exceptionally variable, some specimens having a subcircular outline and others being very elongate. Relation between length of median septum and width and length of pedicle valve is linear with a high degree of dispersion (figs. $22 B, C)$, which suggests that length and width measurements are very variable due to both biologic and mechanical factors. 

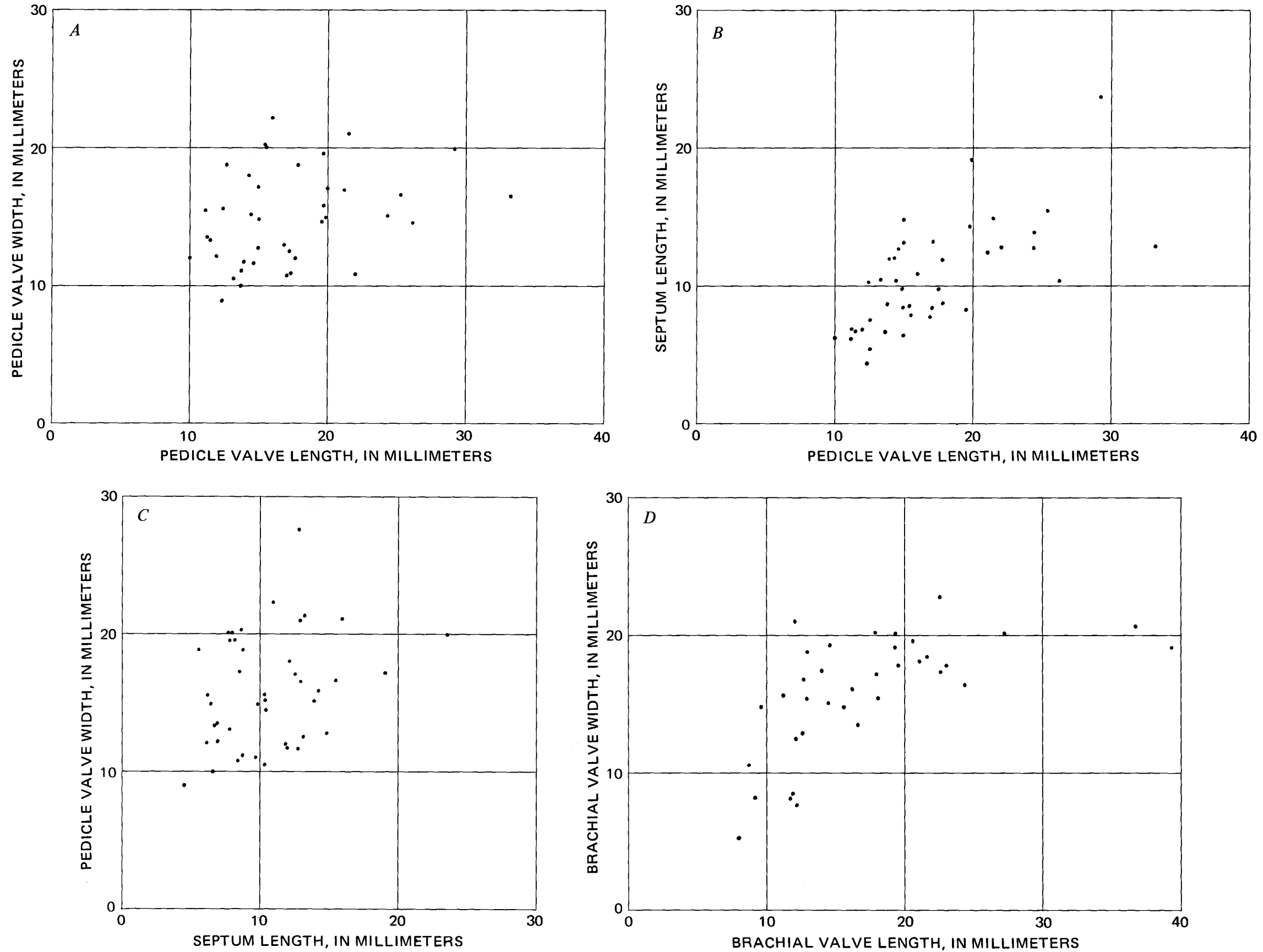

FIGURE 22.-Measurements of Amphigenia parva Clarke, 1907. Tomhegan Formation, USGS loc. 2750-SD, Brassua Lake quadrangle, Somerset County, Maine. 
Comparison.-Amphigenia parva is most similar to $A$. elongata, but the greater size reached by many specimens of the latter indicates that size may be a valid criterion for discriminating between members of the two species. From a collection of several hundred valves of $A$. parva, none was observed to reach the dimensions common to specimens of $A$. elongata, that is, as much as $10 \mathrm{~cm}$ in length. $A$. curta shares with $A$. parva the habit of not reaching more than about $3 \mathrm{~cm}$ maximum length, but $A$. curta has an almost equally biconvex form; brachial valve almost as convex as pedicle valve, whereas in $A$. parva brachial valve is relatively flat as contrasted with deeply carinate pedicle valve. A. chickasawensis has relatively flat valves in contrast to other species of the genus.

Occurrence.-USGS locs. 2750-SD, 2852-SD, 2820-SD, 2873-SD, 2839-SD, 2814-SD, 2752-SD, 2723?-SD, Brassua Lake quadrangle, Somerset County, Maine.

Stratigraphic location. - Tomhegan Formation (Lower Devonian).

Distribution.-Somerset County, Maine, and northwestern New Hampshire (Boucot and Arndt, 1960).

Figured specimens. - USNM 126197, 126196, 126193, 126188, 126219, 126190, 127389.

Measured specimens._USNM 126603A-126603AI, 126604A-126604AP.

Unmeasured specimens.-USNM 125995-125999, 126601.

\author{
Family RHIPIDOTHYRIDIDAE \\ Subfamily GLOBITHYRIDINAE \\ Genus GLOBITHYRIS Cloud, 1942 \\ Globithyris callida (Clarke, 1907) \\ Plate 23, figures 1-5
}

Globithyris callida (Clark, 1907), see Cloud, 1942, p. 84, pl. 11, figs. 5-8, 10-14.

Exterior.-Shell biconvex, deeply inflated pedicle valve more convex than brachial valve. Valve outlines subcircular; brachial valve tending to be transversely elliptical, pedicle valve longitudinally elliptical. Anterior and lateral margins rounded. Anterior commissure rectimarginate, crenulate. Pedicle valve foramen hypothyrid, deltidial plates medially conjunct. Cardinal margins terebratulid. Pedicle valve beak incurved. Costae having round cross section; interspaces relatively narrow, V-shaped form. Faint growth lines cross concentric ornamentation. Twenty-six to forty-three costae, thirty to thirtyeight more common. Maximum width located near midlength.

Pedicle valve interior.-Short, subparallel dental lamellae border delthyrial cavity. Muscle field not discernible.

Brachial valve interior.-Discrete hinge plates border cruralium formed from basally fused crural plates in manner analogous to Amphigenia, forming median septum. Cruralium very small, septum extends to about midlength. Dental sockets shallow, posteriorly border hinge plates. Brachiophores extend out from anterolateral edges of hinge plates.

Measurements.-The relation between length and
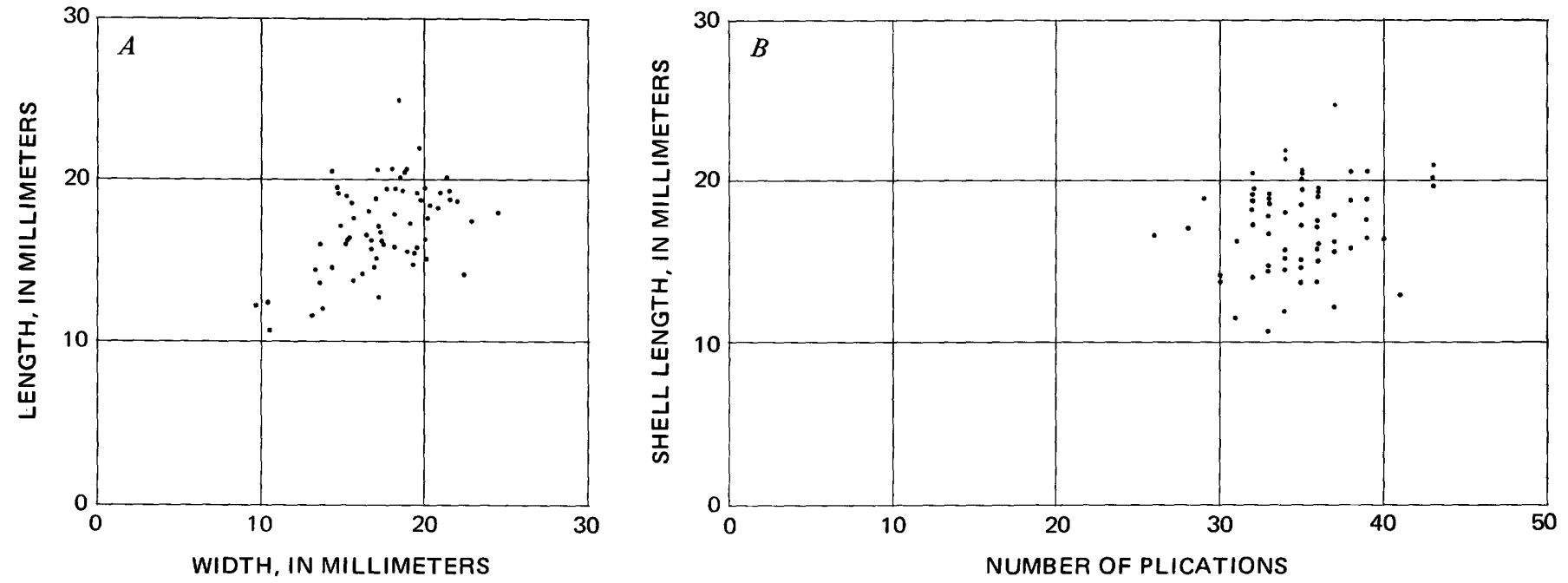

FIGURE 23.-Measurements of Globithyris callida (Clarke, 1907). Tomhegan Formation, USGS loc. 2764-SD, Brassua Lake quadrangle, Somerset County, Maine. $A$, width versus length of shells. $B$, shell length versus number of plications. 
width for both Globithyris callida and G. diania is essentially linear, G. callida shows a much higher degree of dispersion due to mechanical deformation of the specimens (figs. 23A and 24A). G. callida has a larger number of plications, relatively independent of size, than G. diania. G. callida has 30-40 (fig. $23 B$ ) with mode about 35 , whereas $G$. diania has about 15-30 (fig. 24B) with mode about 23 . There is an overlap in the number of plications, but the modes are very distinct from each other.

Comparison.-Globithyris callida is distinguished from $G$. diania by latter's coarse ornamentation. Ornamentation types overlap so that intermediate specimens cannot be assigned specifically unless they are part of a population.

Remarks.-It is notable that both Globithyris and the closely related genus Rhenorensselaeria have both a coarse-ribbed and a fine-ribbed species occuring at the same stratigraphic horizon. It is possible that these differences in ornamentation may reflect some sexual or environmental rather than taxonomic control.

Occurrence.-USGS locs. 2764-SD, 2840-SD, 2736-SD, 2866-SD, 2791-SD, 2757-SD, 2874-SD, 2716-SD, 2772-SD, 2690-SD, 2828-SD, 3085-SD, 2714-SD, 3086-SD, 2859-SD, 2835-SD, 2854-SD, 2727-SD, 2719-SD, 2747-SD, 2744-SD, 2838-SD, 2713-SD, 2714-SD, 3087-SD, Somerset and Piscataquis Counties, Maine; Globithyris cf. G. callida, USGS locs. 2850-SD, 2833-SD, 2863-SD, Somerset County, Maine.

Stratigraphic location. - Tarratine Formation (Lower Devonian), and Tomhegan Formation (Lower Devonian).

Distribution.-Northern Maine.

Figured specimens. - USNM 126165, 67778, 126180.

Measured specimens. - USNM 125946A125946BP.

Unfigured specimens.-USNM 125947-125972, 125977.

\section{Globithyris diania (Clarke, 1907)}

Plate 23, figures 6-13

Globithyris diania (Clarke, 1907). See Cloud, 1942, p. 83.

Remarks.-Globithyris diania is identical to $G$. callida in all regards except number of costae, as discussed under $G$. callida.

Occurrence.UUSG locs. 2869-SD, 2713-SD, 2855-SD, 2867-SD, 2755-SD, 2868-SD, 2851-SD, 2758-SD, 2759-SD, 2715-SD, 2756-SD, 2763-SD, and $G$. cf. G. diania, 2762-SD, 2755-SD, Somerset County, Maine.

Stratigraphic location. - Tarratine Formation
(Lower Devonian) and Tomhegan Formation

(Lower Devonian).

Distribution.-Northern Maine.

Figured specimens.-USNM 126164, 126167, 126182.

Unfigured specimens.-USNM 125978-125993.

Measured specimens._USNM 125994A$125994 \mathrm{AK}$.

\section{Globithyris sp.}

Remarks.-A few localities have yielded globithyrids too poorly preserved to be assigned specifically.

Occurrence.-USGS locs. 2878-SD, 2820-SD, 2754-SD, 2892-SD, 2750-SD, 2752-SD, 2724-SD, 2818-SD, 2836-SD, 2816-SD, 2817-SD, Somerset County, Maine.

Stratigraphic location. - Tarratine Formation (Lower Devonian), and Tomhegan Formation (Lower Devonian).

Unfigured specimens._USNM 125973-125976.

Family MUTATIONELLIDAE Cloud, 1942
Subfamily MUTATIONELLINAE Cloud, 1942
Genus MUTATIONELLA Kozlowski, 1929
Mutationella parlinensis Boucot, Caster, Ives, and Talent, 1963
Plate 23, figures 14-26

Mutationella parlinensis, Boucot, Caster, Ives, and Talent, 1963, p. 110-113, pl. 34, figs. 6-16; pl. 35, figs. 1-2.

Exterior.-Unequally biconvex, brachial valve gently convex, pedicle valve more inflated. Outline subcircular to longitudinally elliptical. Greatest width and thickness usually located near midlength. Anterior commissure rectimarginate, crenulate. Anterior and lateral margins rounded. Cardinal margins submegathyrid. Pedicle foramen submesothyrid. Large shells possess short planareas. Deltidial plates discrete. Pedicle valve beak erect to suberect in large specimens, tends to become slightly incurved over brachial valve. Shell punctate. Costellae increase in width peripherally. Costellae have broad, rounded cross sections separated by narrow, Vshaped interspaces. Usually 40-60 costellae on each valve.

Pedicle valve interior.-Shell thin in umbonal region, no thickening except in delthyrial cavity of large specimens. Dental lamellae short, thin. Muscle field indistinct, elongate in form, extends about onethird distance to anterior margin. Consists of narrow, median diductor laterally bounded by elongate lateral diductor impressions. Posterior portion delthyrial cavity occupied by pedicle callist. Pedicle foramen much narrower than chamber occupied by pedicle callist. Hinge teeth stubby, basally supported by dental lamellae. Interior crenulated by impress 

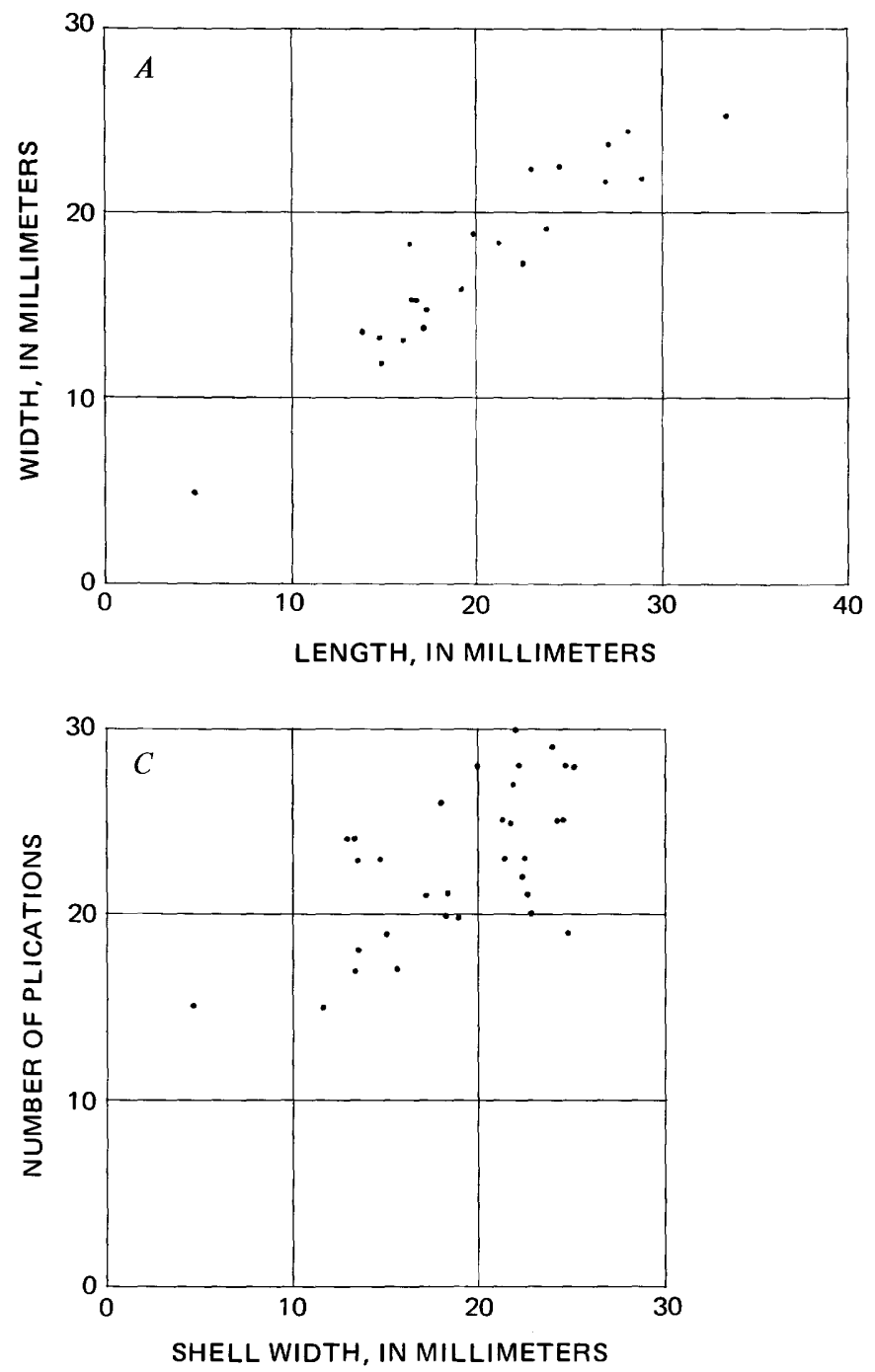

external ornamentation except in umbonal region, which tends to be smooth.

Brachial valve interior.-Discrete hinge plates. A few specimens possess narrow band joining anterior portions of hinge plates. In majority of specimens narrow band not present, because it broke during burial or because it was never formed. Dental sockets elongate, laterally directed; closed over posteromedially by outer socket ridges but widen laterally and are free. Muscle field weakly impressed in most specimens, ellipsoidal outline, one-fifth as wide and one-third as long as valve. Large, ovate, lateral adductors enclose pair narrow, median adductors. Median adductors widen rapidly at anterior end of muscle field. Muscle field bisected by myophragm.

Measurements.-The relation between length and width of brachial valves is linear, with a low degree

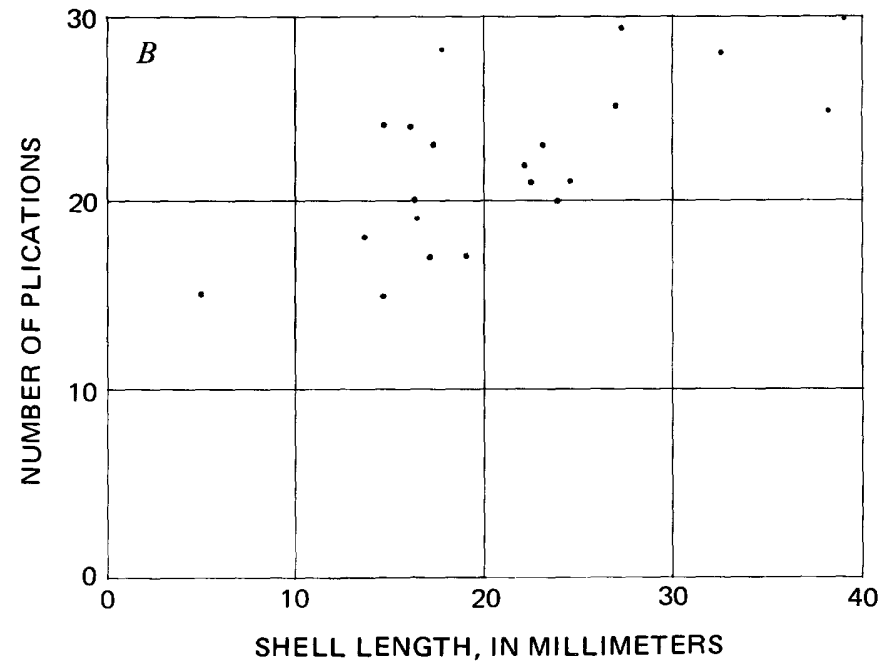

FIGURE 24.-Measurements of Globithyris diania (Clarke, 1907). Tomhegan Formation, USGS loc. 2869-SD, Brassua Lake quadrangle, Somerset County, Maine. $A$, length versus width of shells. $B$, length of shell versus number of plications. $C$, width of shell versus number of plications.

of dispersion (fig. 25A). Number of plications increases with increase in size, with a range of 35-56 recorded (figs. $25 B, C$ ). Increase in number of plications is linear, with a high degree of dispersion.

Comparison.-M. parlinensis is closely allied morphologically to the type species in all regards except that the former attains dimensions about three times those in the latter. Large specimens of $M$. parlinensis have a more carinate pedicle valve than do large specimens of $M$. podolica, but this may be a function of difference in size. Curvature of beak is similar to that in $M$. podolica and is not strongly incurved as in Cloudella stewarti. This species possesses short dental lamellae, as does the type species. Cardinalia in all respects are similar to those of the type species, even in evanescent character of the band connecting the hinge plates. 


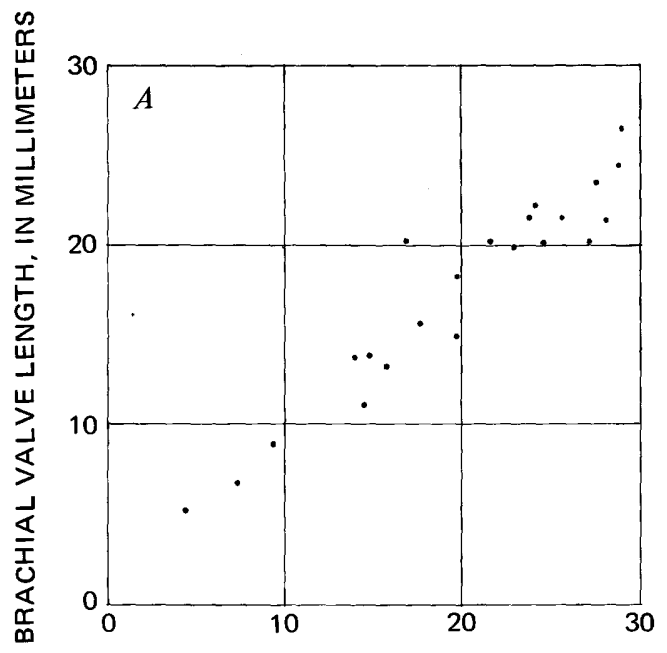

BRACHIAL VALVE WIDTH, IN MILLIMETERS
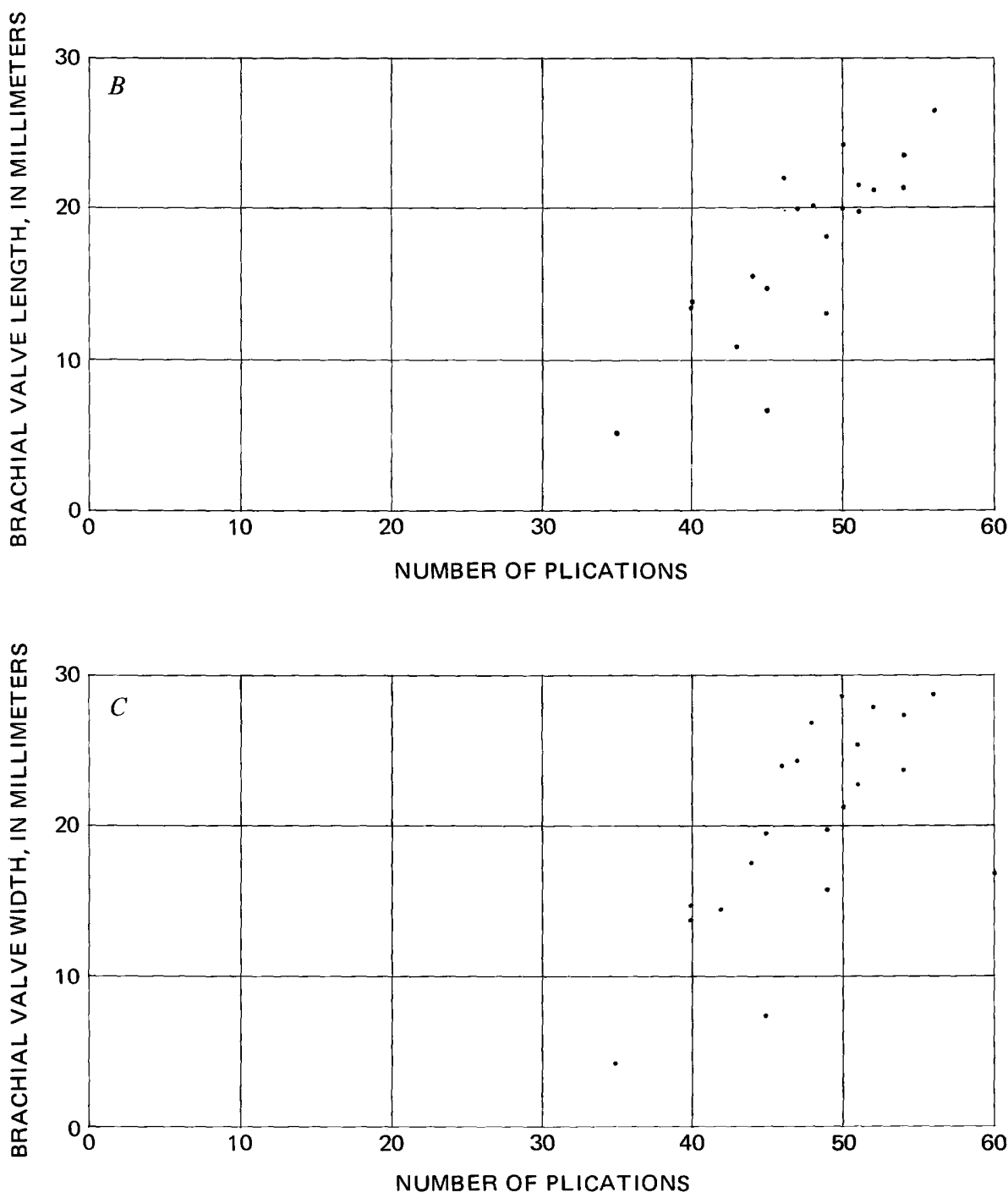

FIgURE 25.-Measurements of Mutationella parlinensis Boucot, Caster, Ives, and Talent, 1963. Lower sandstone of Tarratine Formation, USGS loc. 2718-SD, Long Pond quadrangle, Somerset County, Maine. 
Weakly impressed musculature is similar to that of the type species, as is the thin shell in umbonal region of the pedicle valve.

$M$. parlinensis closely resembles "Trigeria" gaudryi Hall and Clarke, 1893 (non Oehlert, 1877) from Ridgeley Sandstone near Cumberland, Md. No specimens of "T." gaudryi Hall and Clarke (non Oehlert) were available for study, but plaster casts of figured specimens were studied. $M$. barroisi has fewer costellae than $M$. parlinensis.

$M$. parlinensis is similar internally and externally to Mutationella falklandica (Clarke, 1913) except that the latter has relatively coarser costae.

"Rensselaeria" circularis Schuchert, 1913 may be identical (as suggested by Cloud, 1942, p. 83) with "Trigeria" gaudryi Hall and Clark (non Oehlert) but lack of well-preserved material does not permit solution of the problem. " $R$." circularis was assigned by Cloud $(1942$, p. 83$)$ to Globithyris, but this assignment is untenable owing to the absence of crural plates or a median septum in the brachial valve of the former. A myophragm is present in the brachial valve of " $R$." circularis, as in Mutationella, and hinge plates appear to be discrete. It is suggested that " $R$." circularis be assigned questionably to Mutationella pending discovery of more adequate specimens.

Occurence and stratigraphic location.-USGS locs. 2718-SD, 2691-SD, 2719-SD, 2717-SD, 2721-SD, 2731-SD, 2735-SD, 2720-SD, 2765-SD, 2749-SD, 2777-SD, 2795-SD, 2793-SD, 2776-SD, 2767-SD, 2722-SD, 2861-SD, 2727-SD, 2732-SD, 2831-SD, 2890-SD, 2875-SD, 2824-SD, 2865-SD, 2823-SD, 2783-SD, 2821-SD, 2834-SD, 2847-SD, 2862-SD, 3088-SD, 3090-SD, 3225-SD, 2832-SD; Mutationella cf. $M$. parlinensis from USGS locs. 2819-SD, 2825-SD, 2747-SD, Somerset County, Maine, in the Tarratine Formation (Lower Devonian) and questionably the Kineo member of the Tomhegan Formation (Lower Devonian).

Distribution.-Somerset County, Maine, and possibly Cumberland, Md., if "Rensselaeria" circularis and "Trigeria" gaudryi belong to this genus and species. A single poorly preserved specimen from the Percé limestone at Percé, Quebec, in the collections of the Museum of Comparative Zoology, Harvard Univ., Cambridge, Mass., resembles this species. Strata of similar age in Piscataquis and Penobscot Counties, Maine, have not, as yet, produced specimens of Mutationella, but Cloudella (a closely related genus) occurs in the area of Matagamon Dam, Penobscot County, and Mendathyris (another closely related genus) occurs in the Presque Isle area, Aroostock County, Maine.
Holotype.-UNSM 126178.

Figured specimens.-USNM 126168, 126185,

126186, 126166, 126173, 126171.

Measured specimens.-USNM $126671 \mathrm{~A}-\mathrm{V}$.

Unmeasured specimens.-USNM 126638, 126674.

\section{REFERENCES CITED}

Albee, A. L., and Boudette, E. L., 1972, Geology of the Attean quadrangle, Somerset County, Maine: U.S. Geol. Survey Bull. 1297, 110 p.

Amsden, T. W., 1951, Brachiopods of the Henryhouse Formation (Silurian) of Oklahoma: Jour. Paleontology, v. 25, no. 1, p. 69-96.

Berdan, J. M., 1963, Eccentricosta, a new Upper Silurian brachiopod genus: Jour. Paleontology, v. 37, no. 1, p. 245-256.

Berry, W. B. N., and Boucot, A. J.. 1970, Correlation of the North American Silurian rocks: Geol. Soc. America Spec. Paper 102, 289 p.

Billings, Elkanah, 1874, Paleozoic fossils, v. 2, pt. 1 : Canada Geol. Survey, 144 p., pls. 1-10.

Boucot, A. J., 1959a, Early Devonian Ambocoeliinae (Brachiopoda) : Jour. Paleontology, v. 33, no. 1, p. 16-24, pls. $1,2$.

1959b, Brachiopods of the Lower Devonian rocks at Highland Mills, New York: Jour. Paleontology, v. 33, no. 5 , p. 727-769.

1961, Stratigraphy of the Moose River synclinorium, Maine: U.S. Geol. Survey Bull. 1111-E, p. 153-188.

- 1969, Geology of the Moose River and Roach River Synclinoria, northwestern Maine; with contributions by E. W. Heath: Maine Geol. Survey Bull. no. 21, 117 p.

Boucot, A. J., and Amsden, T. W., 1964, Chonostrophiella, a new genus of chonostrophid brachiopod: Jour. Paleontology, v. 38 , no. 5, p. 881-884, pl. 141.

Boucot, A. J., and Arndt, Robert, 1960, Fossils of the Littleton Formation (Lower Devonian) of New Hampshire: U.S. Geol. Surv. Prof. Paper 334-B, p, 41-51.

Boucot, A. J., Caster, K. E., Ives, David, and Talent, J. A., 1963, Relationships of a new Lower Devonian terebratuloid (Brachiopoda) from Antarctica: Bull. Am. Paleontology, v. 46 , no. 207 , p. $77-151$, pls. $16-41$.

Boucot, A. J., and Harper, C. W., 1968, Silurian to lower Middle Devonian Chonetacea: Jour. Paleontology, v. 42, no. 1 , p. 143-176, pls. 27-30.

Boucot, A. J., and Johnson, J. G., 1967a, Species and distribution of Coelospira (Brachiopoda) : Jour. Paleontology, v. 41 , no. 5, p. 1226-1241, pls. 163-166.

1967b, Paleogeography and correlation of Appalachian Province Lower Devonian sedimentary rocks: Tulsa Geol. Soc. Digest, v. 35, p. 35-87, 2 pls.

- 1968, Brachiopods of the Bois Blanc Formation in New York: U.S. Geol. Survey Prof. Paper 584-B, 27 p.

Boucot, A. J., Johnson, J. G., and Staton, R. D., 1964, On some atrypoid, retzioid and athyridoid Brachiopoda: Jour. Paleontology, v. 38, no. 5, p. 805-822.

Boucot, A. J., Johnson, J. G., and Talent, J. A., 1969, Early Devonian brachiopod zoogeography: Geol. Soc. America Spec. Paper 119, 106 p.

Boucot, A. J., and Yochelson, E. L., 1966, Paleozoic Gastropoda from the Moose River synclinorium, northern Maine: U.S. Geol. Survey Prof. Paper 503-A, p. A1A20, pls. 1-3. 
Caster, K. E., 1939, A Devonian fauna from Colombia: Bull. Am. Paleontology, v. 24, no. 83, p. 1-218.

Clarke, J. M., 1900, The Oriskany fauna of Becraft Mountain, Columbia County, N.Y.: New York State Mus. Mem. 3, v. 3, 101 p.

1907, Some new Devonic fossils: New York State Mus. Bull. 107, p. 153-291.

- 1909, Early Devonic history of New York and eastern North America: New York State Mus. Mem. 9, pt. 2, 250 p., 34 pls.

Cloud, P. E., Jr., 1942, Terebratuloid Brachiopoda of the Silurian and Devonian: Geol. Soc. America Spec. Paper 38, 182 p., 26 pls.

Cooper, G. A., 1956, Chazy an and related brachiopods: Smithsonian Misc. Coll., v. 127, 1024 p.

Dunbar, C. O., 1919, Stratigraphy and correlation of the Devonian of western Tennessee: Tennessee State Geol. Survey, Bull. 21, 127 p.

Foerste, A. F., 1903, Silurian and Devonian limestones cf western Tennessee: Jour. Geology, v. 11, p. 554-583, 679-715.

- 1909, Fossils from the Silurian formations of Tennessee, Indiana, and Kentucky: Denison Univ. Sci. Lab. Bull. 14, p. 61-116.

Goldring, Winifred, 1933, A new species of crinoid from the Devonian (Oriskany) of Maine: Portland Soc. Nat. History Proc., v. 4, p. 153-155, pls. 3, 4.

Hall, James, 1863, Contributions to palaeontology: New York State Cabinet of Natural History 16th annual report, p. 3-226.

Hall, James, and Clarke, J. M., 1894, An introduction to the study of the genera of Palaeozoic Brachiopoda: New York Geol. Survey, Palaeontology, v. 8, pt. 2; 1893, prepr., p. 1-317; 1894, 394 p., pls. 21-84 [1895].

Lespérance, P. J., 1968, Ordovician and Silurian trilobite faunas of the White Head Formation, Perce region, Québec: Jour. Paleontology, v. 42, no. 3, p. 811-826.

Neuman, R. B., 1968, Paleogeographic implications of Ordovician shelly fossils in the Magog belt of the northern Appalachian region, Chap. 3 in Zen, E-an, and others, eds., Studies of Appalachian geology, northern and maritime: New York and London, Interscience Publishers, p. 35-48.

Oliver, W. A., Jr., 1960, Devonian rugose corals from north- ern Maine: U.S. Geol. Survey Bull. 1111-A, p. 1-23, pls. 1-5.

1962, Silurian rugose corals from the Lake Témiscouata area, Quebec: U.S. Geol. Survey Prof. Paper 430-B, p. 11-19, pls. 5-8 [1963].

1967, Succession of rugose coral faunas in the Lower and Middle Devonian of eastern North America, in Internat. Symposium on the Devonian System, Calgary, Alberta, 1967 [Proc.] V. 2: Calgary, Alberta, Alberta Soc. Petroleum Geologists, p. 733-744 [1968].

Pirsson, L. V., and Schuchert, Charles, 1914, Note on the occurrence of the Oriskany Formation on Parlin Stream, Maine: Am. Jour. Sci., Ser. 4, v. 37, p. 221-224.

Schuchert, Charles, and Cooper, G. A., 1931, Synopsis of the brachiopod genera of the suborders Orthoidea and Pentameroidea, with notes on the Telotremata: Am. Jour. Sci., Ser. 5, v. 22, p. 241-251.

Stumm, E. C., 1962, Silurian corals from the Moose River synclinorium, Maine: U.S. Geol. Survey Prof. Paper 430-A, p. 1-9, pls. 1-4.

Walmsley, V. G., Boucot, A. J., and Harper, C. W., 1969, Silurian and lower Devonian salopinid brachiopods: Jour. Paleontology, v, 43, no. 2, p. 492-516.

Weller, S., 1903, The Paleozoic faunas: New Jersey Geol. Survey, Pal. 3, 462 p.

Whittington, H. B., and Campbell, K. S. W., 1967, Silicified Silurian trilobites from Maine: Harvard Univ., Mus. Comp. Zoology Bull., v. 135, p. 447-483, 19 pls.

Williams, Alwyn, 1951, Llandovery brachiopods from Wales with special reference to the Llandovery District: Geol. Soc. London Quart. Jour., v. 107, pt. 1, no. 425, p. 85136.

1953, North American and European stropheodontids: their morphology and systematics: Geol. Soc. America Mem. 56, 67 p.

Williams, Alwyn, and others, 1965, Treatise on invertebrate paleontology, Part H, Brachiopoda, V. 1-2: New York, Geol. Soc. America (and Univ. Kansas Press), 927 p.

Williams, H. S., and Breger, C. L., 1916, The fauna of the Chapman sandstone of Maine: U.S. Geol. Survey Prof. Paper 89, 347 p., 27 pls.

Woodard, H. H., 1951, Report on the geology of a portion of the Spencer Lake area, Maine: Maine Geol. Survey Rept. State Geologist $1949-50$, p. 68-77. 



\section{INDEX}

\section{A}

Page

acinum, Rhynchonella

acinus, Diabolirhynchia Rhychonella

Acrospirifer

angularis atlanticus hartleyi intermedius _........... 47 murchisoni -...- 41, 43, 47; pl. 16 olssoni -

sp. 1 sp. 2 -

aequiradiata, Atrypa

Age, faunas ..... 1

Hardwood Mountain Formation -.. 2

Little Big Wood Pond beds ...... 2

alsa, Discomyorthis _..... 13

Rhipidomella _................. 13

altisulcata, Ancillotoechia _._.

Ambocoeliidae -

Ambocoeliinae -

Amphigenia -... 3, 70, 72 chickasawensis _....... 72 curta elongata parva

Amphigeniinae -.... 70

Amphistrophia _.................. 1 funiculata _-

ampla, Strophonella

Ancillotoechia -....... 30

altisulcata _._..._._. $30 ;$ pl. 12 bialveata -........ 30 haraganensis _......... 30 sp _._............. 30; pl. 12 angularis, Acrospirifer _-..-...-... 43 angustiplicata zaleszczykiensis, Howellella 41 Anopliidae -.............. 25 Anoplothecidae _.................. 38 Anopliinae Anthyrididae _......... 65 Anthyridinae - 65 Antispirifer -....- 50 harroldi

Appalachian forms 3 Appalachian ostracode faunda 3 arctostriata, Atrypa _..... arcuaria, Isorthis _.............. 10 arcuata, Eodevonaria _.......... 3, 27; pl. 11 Aroostook County _._....... 3 atlanticus, Acrospirifer _........ 3, 46; pl. 17

Atrypa aequiradiata _._...... 66 arctostriata reticularis _._._._._._. 2,36 ; pl. 15 reticularis s.l tennesseenis _..._.

Atrypidae (-... 36

Atrypinae _...... 36

avus, Nanothyris subglobosa

B

Baltic-type fauna 3

barroisi, Mutationella
[Italic page numbers indicate major references]

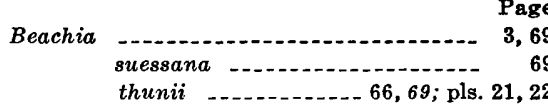

Bear Pond Limestone Member

Beck Pond -

Beck Pond Limestone

beckensis, Sieberella _-_........ 20; pl. 6

becraftensis, Schuchertella _.......... 24; pl. 9

Berdan, J. M., cited _........ 2

bialveata, Ancillotoechia _........... 30

Rhynchonella .............. 30

bidentata, Rhynchonella _............ 30

blainvillei, Protoleptostrophia _.... 22; pl. 8

brownsportensis, Orthostrophia _...... 4; pl. 1

\section{C}

callida, Globithyris _..._....... 72, 73; pl. 23 Camarotoechia -........ 30 canadensis, Dawsonelloides _...._ 26; pls. 10,11 Charionoides chickasavensis, Amphigenia _....... 72 Chonetidae -........... 25 Chonetinae -........... 25

Chonostrophiella _................... 1,28 complanata -.-- 28; pls. 11,12

Chonostrophiellinae _............. 28 circularis, Rensselaeria _...........- 76

cliftonensis, Dalejina _............... 16

Cloud, Preston E., Jr., cited _..... 1

Cloudella -_-_._- 76

stewarti
Cloudothyris _.

postovalis

Coelospira _........ 1, 2, 38 sp

Coelospirinae -...- 38 coeymanensis, Gypidula _............ 19 complanata, Chonostrophiella _-_ 28; pls. 11, 12 Conodonts, Little Big Wood Pond ..... 2 cooperi, Plicoplasia ................ 63 Corals, Little Big Wood Pond ........ Costellirostra -....... 34 Costellispirifer sp -_. perimele sp Costispiriferinae -......... 61 crassa, Nanothyris subglobosa -...-.-. 66 cumberlandiae, Spirifer -_._._.-. 60

Cupularostrum _......... 29 macrocosta recticostatum -.--.-- 30 sp _............... $30 ; \mathrm{pl} .12$ curta, Amphigenia _...... 72 cycloptera, Howellella cyclopterus, Howellella _......... 40; pl. 16 Cyrtina $\quad$ rostrata Cyrtinidae ..... 63 Cyrtininae _........... 63 cyrtinoides, Megakozlowskiella Cyrtoniscus _........... 1,25 nectus _..._. Centronellidae -.......... 65 Coral analysis, Oliver, W. A., Jr. -...- 4 Costispirifer _.
D

Page

Dalejina

cliftonensis newsomensis _.............. 16 subtriangularis _........ 16 sp. 1 _ sp. 2 - 16 sp

Dalmanellidae _.................... 9

Dawsonelloides .................. 1, 3, 26 Delthyrididae canadensis _..... 26; pls. 10,11

Delthyridinae _... 39 Delthyris _............... 39 (Delthyris) - 2 kozlowskii _._._._._._._. $39 ; \mathrm{pl} .16$ pegramensis .............. 39 demissa, Stropheodonta Devonian, Lower ..... 3

Diabolirhynchia _........ 30 acinus -....... 30 diania, Globithyris _... Dicaelosia _. sp _... Dicaelosiidae - 11 Dinorthidae - .

Discomyorthis _.................. 12, 13, 16 alsa eryna - 13 musculosa _..._..... 13 musculosa solaris_._ 12; pls. 3.4 oblata -..-_._sp

Dolerorthinae Dolerorthis _... hami _........ 7 ; pl. 2 hobbstownensis _......... 5, 6; pl. 1 rustica osiliensis _......... 7 sp s.s. - - 6 doris, Charionoides _.......... 3, 64; pl. 20 Draboviine -........... 18 dryope, Rhynchonella duodenarius, Spirifer _............. 47

$\mathbf{E}$

Early Devonian fauna, Moose River synclinorium -..-.-...-.

Early Silurian fossils, Limestone Hill -. 1 Early Wenlock brachiopods, Limestone

Hill _..... 1 34 medialis _... sp -

Eatoniidae -...... 34

Eccentricosta _............ 2, 3, 25 sp

Eitelian age ............... 4 elongata, Amphigenia engelmanni, Spirifer _._._._._. 51 Eodevonaria _._. arcuata _......... 3, 27; pl. 11

Eospirifer Eospiriferidae

Eospiriferinae _... 39

eryna, Discomyorthis ... 13 


$\begin{array}{lr}\text { Esopus age } & \begin{array}{r}\text { Page } \\ \text { European forms }\end{array} \\ \begin{array}{lr}\text { Eurythyridinae } \\ \text { excellens, Rhynchonella }\end{array} & 39 \\ & \\ & \\ & \\ \text { falklandica, Mutationella } & \\ \text { Famine Limestone } & \\ \text { Faunas, age - } & \\ \text { flabellites, Leptocoelia } & \\ \text { formosa, Machaeraria } & \\ \text { funiculata, Amphistrophia } & \end{array}$

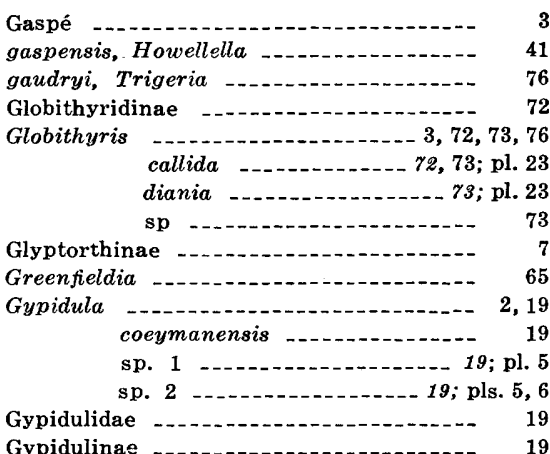

\section{H}

hami, Dolerorthis _............... 7; pl. 2 haraganensis, Ancillotoechia -...-.---- 30 Hardwood Mountain Formation --.--- 2 harroldi, Antispirifer _........... 50; pl. 18

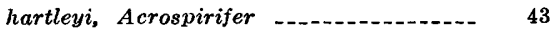
Hedeina Helderberg age - 3 Helderberg faunas Hesperothidae -

Hesperorthis sp hitchcocki, Salopina Hobbstown Formation, lower

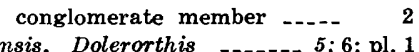
hobbstownensis, Dolerorthis _-..- 5;6; pl. 1 hodgei, Nanothyris _............ 65 ; pl. 21 Howellella _-_._........ 2, 39 angustiplicata Zaleszczykiensis 41 cycloptera -

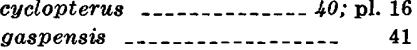
gaspensis
mckenzica
nerei tomheganensis _... $40 ; \mathrm{pl} .16$ sp

intermedius, Acrospirifer Introduction

Isorthinae Isorthis arcuaria perelegans .............. 10, 11; pl. 3 sp. 1 - 10,$11 ;$ pl. 2

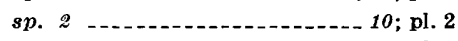
sp. 3 _.

Kineo Rhyolite
Kirkidium knighti

knighti, Kirkidium

Kozlowskiellina

(6) 62

kozlowskii, Delthyris _..._._._._. 39 ; pl. 16

\section{$\mathbf{L}$}

lata, Meristella _............. Late Llandovery brachiopods,

Limestone Hill _......... 1

Leptaena

Leptaenidae _...-...- 20

Leptaenisca -...- 25 sp -2.

Leptaenoideinae -...... 25

Leptocoelia _............. 38 flabellites -_.

Leptocoeliidae -...- 38

Leptostrophia _._. 21, 22 magnifica _-_._._._. 21; pl. 7 sp

Levenea subcarinata _......... 11 sp -

Limbinaria muricata

Limestone Hill, Early Silurian fossils_- 1, 3 early Wenlock

brachiopods --.-late Llandovery

brachiopods -......... 1

$\begin{array}{rrr}\text { Lissatrypa } & \\ \text { sp } & & \end{array}$

Lissatrypidae

Little Big Wood Pond ....... 2

Lobster Lake Formation -

lucia, Orthis

Ludlow age

\section{M}

Machaeraria -.formosa mainensis _._._._._. $35 ;$ pl. 14 macra, Mucrospirifer macrocosta, Cupularostrum _....... 29; pl. 12 macropleura, Hedeina _._. magnifica, Leptostrophia _..._.... 21; pl. 7 mainensis, Machaeraris _..... 35; pl. 14 mckenzica, Howellella _............ 41 medialis, Eatonia Megakozlowskiella cyrtinoides - 62

Megalanteris thunei Meganteris

Meifodia

Merista -

tennesseensis _........ 68 ; pl. 20

Meristella _.................... 64 lata sp -

Meristellidae _... 63

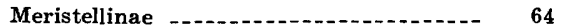

Meristinae -..... 63

Metaplasia minuta _... paucicostata -_._-_._-_. 62; pl. 19 pyxidata -...... 62

minuta, Metaplasia _........... 62; pl. 29 Mont Wissick Formation Moose River synclinorium, purpose geologic study -... 1 Mucrospirifer Mucrospiriferinae - 60 murchisoni, Acrospirifer _.... 41,43, 47; pl. 16

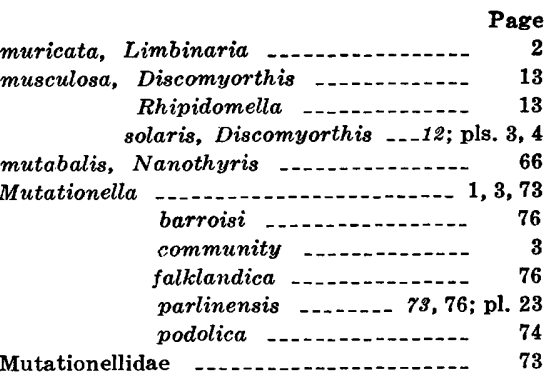

Mutatione!linae

$\mathbf{N}$

Nanospira _... 37 sp hodgei mutabilis _............. 66 reesidei _..... 66 subglobosa subglobosa avus _._._._. 66 subglobosa crassa nectus, Cyrtoniscus -........... 25; pl. 9 nerei, Howellella -.... 41 New Brunswick -..... 3 neusomensis, Dalejina _............ 16

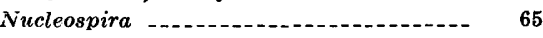
Nucleospirida sp

\section{0}

oblata, Discomyorthis 12,13 Old World genus -.

-

Oliver, W. A., Jr, olssoni, Acrospirifer -....-..-..Onondaga age

Ordovician age

$$
\text { Late - }
$$

Middle

Ordovician trilobites,

Oriskany age

Orthambonites $\mathrm{sp}$

Orthidae

Orthinae

Orthis lucia

-17

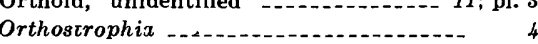
brownsportensis -...- 4; pl. 1 strophomenoides _..... 4; pl. 1

Orthostrophina

osiliensis, Dolerorthis rustica

Ostrocodes, Little Big Wood Pond -.... 2

\section{$\mathbf{P}$}

Paleontology, systematic -...- 4 Parker Bog Formation
parlinensis, Mutationella parva, Amphigenia _........... 70, pl. 22 paucicostata, Metaplasia _..._._. 62; pl. 19 pegramensis, Delthyris -...-..- 39 Reticularia _........... 39

Penobscot County Pentameridae Pentamerinae -....... 20 Pentameroides - . Pentamerus sp -....... 1, 20; pl. 6 perelegans, Isorthis _......... 10, 11; pl. 3 perimele, Costellispirifer _...._. $51 ;$ pl. 18 Spirifer pirssonae, Spirifer planoconvexa, Platyorthis _......... 16; pl. 4 


\begin{tabular}{|c|c|}
\hline Page & Page \\
\hline Platyorthinae & Rhynchonella acinus \\
\hline Platyorthis & bialveata \\
\hline planoconvexa & bidentatx \\
\hline Plectambonitidae & dryope - \\
\hline Plectambonitinae & excellens \\
\hline plicata, Plicoplasia & Rhynchotrematidae \\
\hline Plicoplasia - & roemeri, Sieberella \\
\hline cooperi & rostrata, Cyrtina \\
\hline plicata & rustica osiliensis, Dolerorthis \\
\hline podolica, Mutationella & \\
\hline postovalis, Cloudothyris _..... $69 ; \mathrm{pl} .22$ & $\mathbf{s}$ \\
\hline Pridoli age & \\
\hline Protathyris - & Saint George, Quebec \\
\hline Protathyris sp _. & Sally Mountain \\
\hline $\begin{array}{rlr}\text { Protoleptostrophia } & 22 \\
& \text { blainvillei } & \\
& \end{array}$ & Salopina \\
\hline$s p \quad \ldots \ldots \ldots 22,23 ;$ pls. 7,8 & Schizophoria striatula \\
\hline Provinciality & sp \\
\hline Ptychopleurelle & Schizophoriidae 18 \\
\hline sp $\quad \ldots-\ldots-\ldots$ & Schizoramma \\
\hline 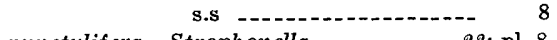 & subplicata \\
\hline punctulifera, Strophonella _._._._. 23; pl. 8 & Schoharie age \\
\hline $\begin{array}{l}\text { Purpose, geologic study Moose River } \\
\text { synclinorium }\end{array}$ & Schuchertella - 24 \\
\hline pyxidata, Metaplasia & $\begin{array}{l}\text { becraftensis } \\
\text { sp }\end{array}$ \\
\hline & Schuchertellidae \\
\hline $\mathbf{Q}, \mathbf{R}$ & Schuchertellinae \\
\hline & Seboomook Formation \\
\hline Quebec & Sieberella \\
\hline recticostatum, Cupularostrum _....... & beckensis \\
\hline reesidei, Nanothyris _. & roemeri \\
\hline References cited - & - \\
\hline Rensselaeria & sieberi, Sieberella \\
\hline 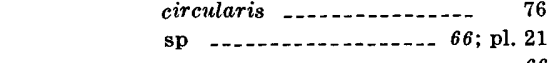 & $\begin{array}{l}\text { Silurian age } \\
\text { solaris, Discomyorthis musculosa-- 12; pls. 3, } 4\end{array}$ \\
\hline s.9 $\quad$. $\quad$. & Somerset County \\
\hline Rensselaeriinae - & Sowerbyites $s p$ \\
\hline $\begin{array}{lll}\text { Resserella } & \\
& \mathrm{sp} & -\end{array}$ & $\begin{array}{l}\text { Spencer Mountain outlier } \\
\text { Sphaerirhynchia }\end{array}$ \\
\hline Reticularia pegramensis & sp. 1 \\
\hline $\begin{array}{r}\text { reticularis, Atrypa } \\
\text { Atrypa s.l }\end{array}$ & $\begin{array}{c}\text { sp. } 2 \text { - } 32 \text {; } 13 \\
\text { sp. } 3 \text { pl. } 13\end{array}$ \\
\hline Rhenish community & sp \\
\hline Rhenorensselaeria & Spinoplasia \\
\hline Rhipidomella alsa & Spirifer cumberlandiae \\
\hline musculosa & duodenarius \\
\hline Rhipidomellidae & engelmanni \\
\hline Rhipidomellinae .... & perimele \\
\hline Rhipidothyrididae - & pirssonae \\
\hline rhomboidalis, Leptaena _.... 20; pl. 6 & worthenanus \\
\hline Rhynchonella acinum & stewarti, Cloudella \\
\hline
\end{tabular}

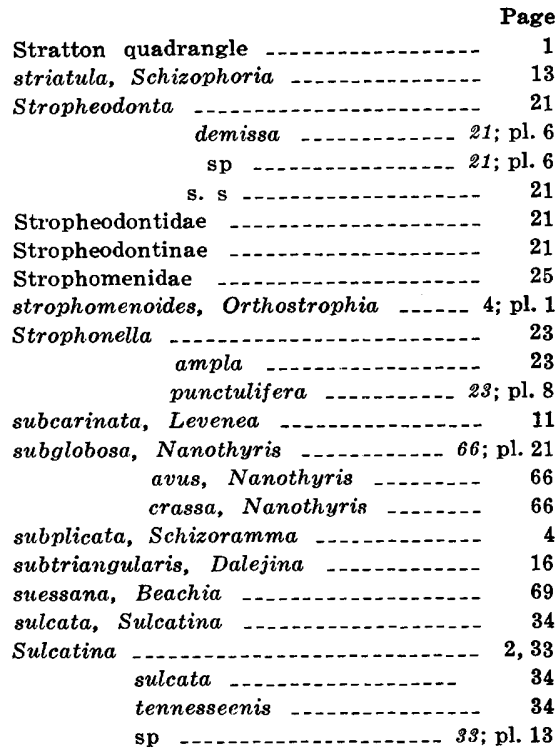

Systematic Paleontology

\section{$\mathbf{T}$}

Tarratine Formation -...-...-...- 3 tennesseenis, Atrypa $-{ }_{-1}$ Merista Sulcatina --_-_- 34

thunei, Megalanteris _.......... 69 thunii, Beachia -.-.-.- 66, 69; pls. 21, 22 Tomhegan Formation -...-..-... 3 tomheganensis, Howellella _...-.... 40; pl. 16 Tonoloway Limestone -...-..-.-. 2

$\begin{array}{ll}\text { Trigeria gaudryi } & \\ \text { Trigonirhynchiidae } & -\end{array}$

\section{$\mathrm{U}, \mathrm{v}, \mathrm{w}, \mathrm{z}$}

Uncinulidae

Valcourea

Wenlock age, late

worthenanus, Spirifer

zaleszczykiensis, Howellella

angustiplicata 



\section{PLATES $1-23$}

[Contact photographs of the plates in this report are available, at cost, from U.S. Geological Survey Library, Federal Center, Denver, Colorado 80225] 


\section{PLATE 1}

Figures 1-5. Orthostrophia cf. O. brownsportensis Amsden. 1949 (p. 4).

Hardwood Mountain Formation. USGS loc. 4843-SD, Attean quadrangle, Somerset County, Maine. $\times 3$.

1. Impression of interior of pedicle valve. Note tripartite form of muscle field with concentric striae, obsolescent nature of dental lamellae, presence of umbonal fold and anterior sulcus. Note low groove in bottom of delthyrial cavity which may have delimited pedicle adjustor area. USNM 160109A.

2. Impression of exterior of pedicle valve. Note presence of fold in umbonal region, costae originating by both bifurcation and implantation. Concentric filae also prominent, together with concentric growth lines. Counterpart to specimen in figure 1. USNM 160109B.

3. Impression of interior of brachial valve. Note quadripartite form of muscle field, linear cardinal process laterally bounded by parallel ridges, and broad myophragm extending anteriorly from cardinal process to bisect muscle field. USNM 160110A.

4. Impression of exterior of brachial valve. Note presence of prominent sulcus in umbonal region. Counterpart to specimen in figure 3. USNM $160110 \mathrm{~B}$.

5. Impression of interior of pedicle valve. Note the form of the muscle field and the presence of a fold in the umbonal region which changes into a sulcus anteriorly. USNM 160111.

6-12. Orthostrophia cf. O. strophomenoides (Hall, 1857) (p. 4).

Beck Pond Limestone. USGS loc. 3499-SD, Spencer Lake quadrangle, Somerset County, Maine. $\times 1$.

6. Posterior view. Note relatively greater length of pedicle interarea and posteriorly sulcate brachial valve. USNM 125786B.

7. Anterior view. Note uniplicate commissure with fold on brachial valve. USNM 125786B.

8. Side view. Note somewhat greater convexity of pedicle valve. USNM 125786B.

9. View of pedicle valve. Note sulcus present anteriorly and absent posteriorly. USNM 125786B.

10. View of brachial valve. Note sulcus present posteriorly and fold present anteriorly. USNM 125786B.

11. Internal impression of pedicle valve. Note short dental lamellae, tripartite muscle field and impression of costellae anteromedially. USNM 125786A.

12. Internal impression of brachial valve. Note quadripartite adductor impressions, short median septum, bladelike cardinal process, and stubby brachiophores. USNM $125785 \mathrm{~B}$.

13-14. Schizoramma fissistriata Foerste, 1909 (p. 4).

Interior and exterior of brachial valve $(\times 2)$. Note pair of ridges lateral to cardinal process ridge. USNM 87017. Osgood Formation. New Marion, Indiana

15-17. Orthambonites? sp. (p. 5).

Latex replica of exterior: posterior, anterior, and brachial views. $(\times 3)$. USNM 125753. Kennebec Formation. USGS loc. 4317-CO, Brassua Lake quadrangle, Somerset County, Maine.

18-26. Dolerorthis hobbstownensis Boucot, n. sp. (p.5).

Base of Hobbstown Formation. USGS loc. 3479-SD, Spencer Lake quadrangle, Somerset County, Maine. Holotype, USNM 125796A, B.

18, 22. Latex replica and impression of interior of brachial valve $(\times 2)$. USNM 125796B.

19. Posterior view of latex replica of exterior of pedicle valve $(\times 4)$. USNM 125903A.

20,25 . Impression and latex replica of exterior of brachial valve $(\times 2)$. USNM 125796A.

21, 23. Impression and latex replica of exterior of pedicle valve $(\times 2)$. USNM 125903A.

24,26 . Impression and latex replica of interior of pedicle valve $(\times 2)$. USNM $125797 \mathrm{~B}$. 
GEOLOGICAL SUR VEY

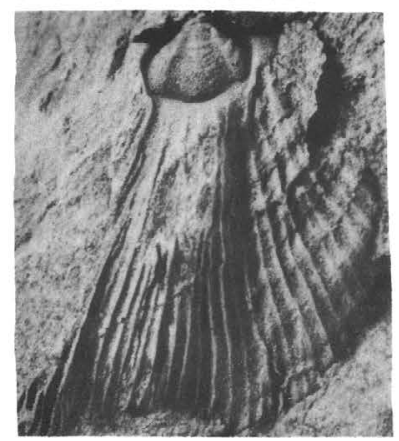

1
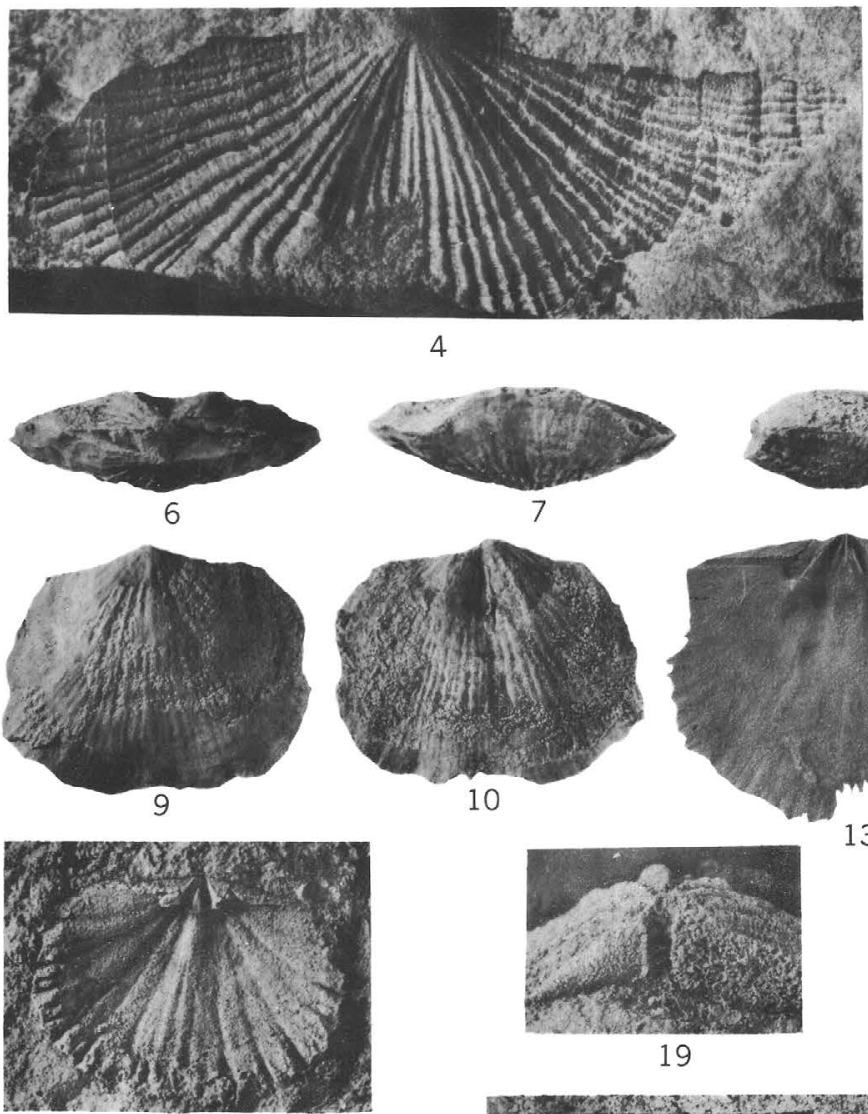

18

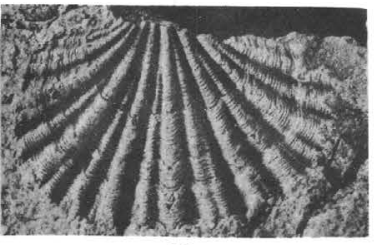

20

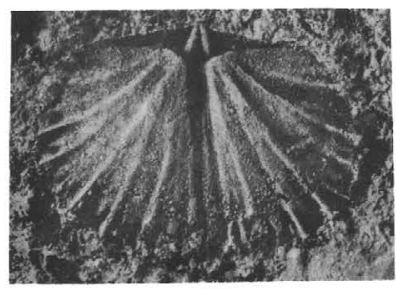

22
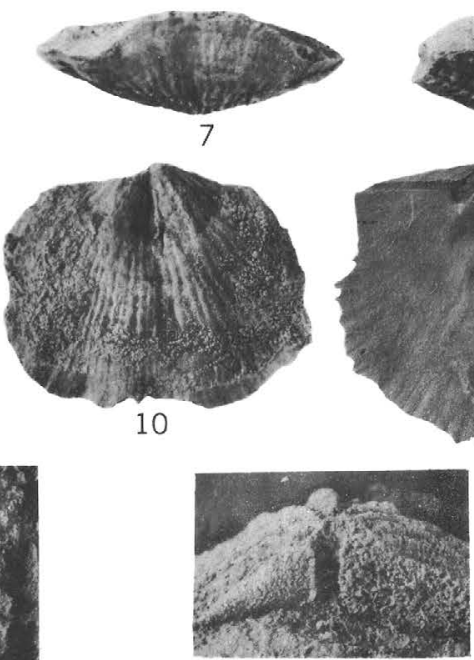

21

23

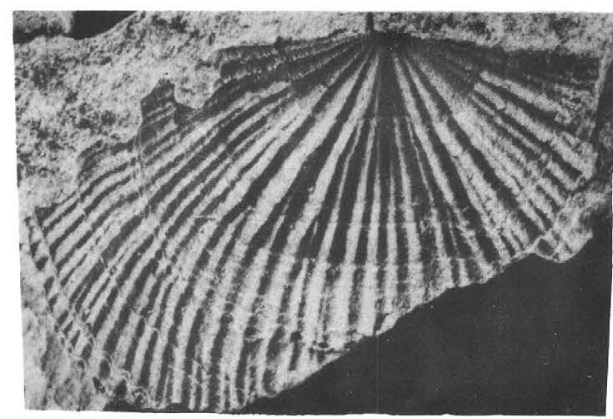

PROFESSIONAL PAPER 784 PLATE 1

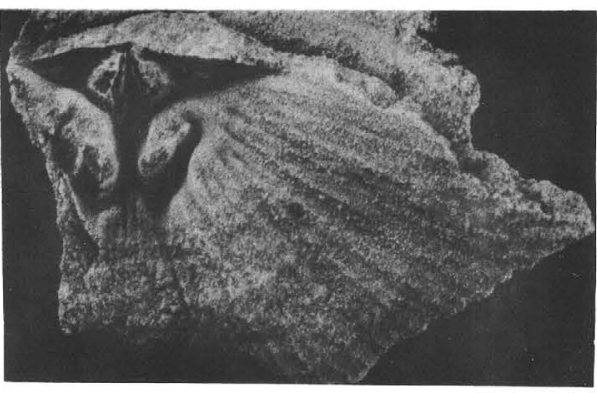

3
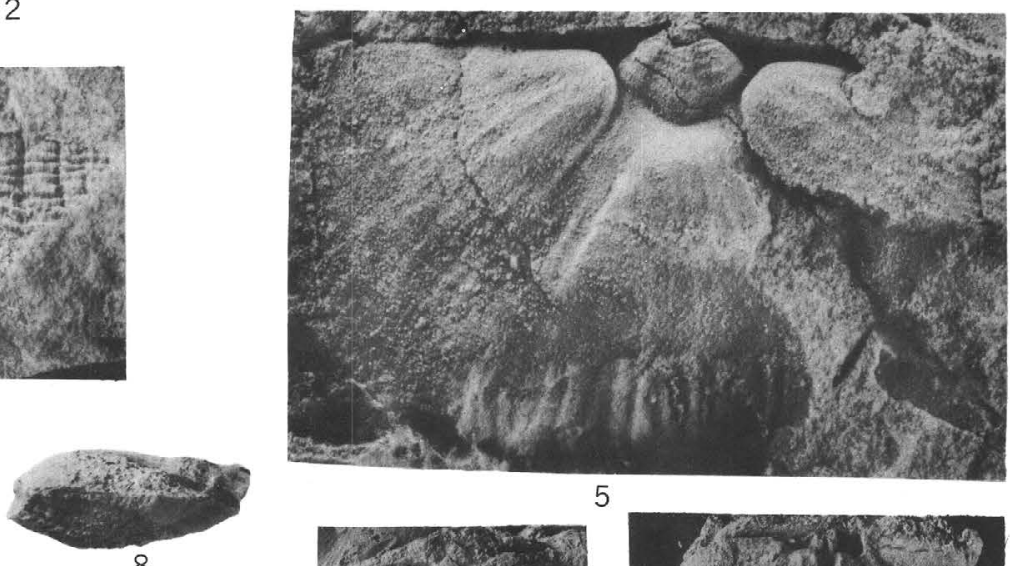

8
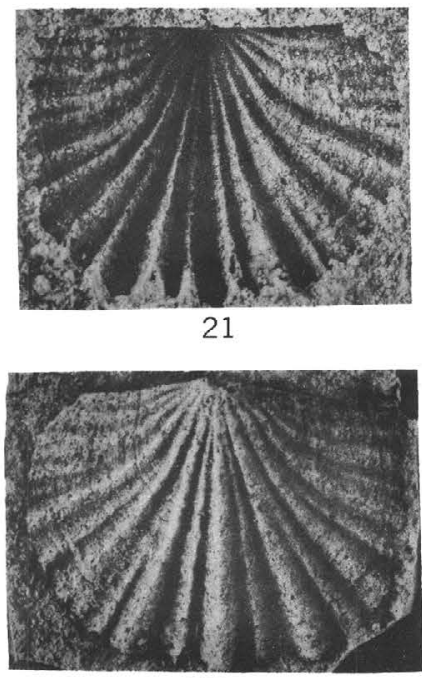

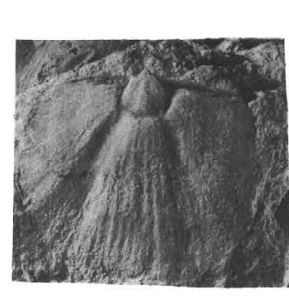

11
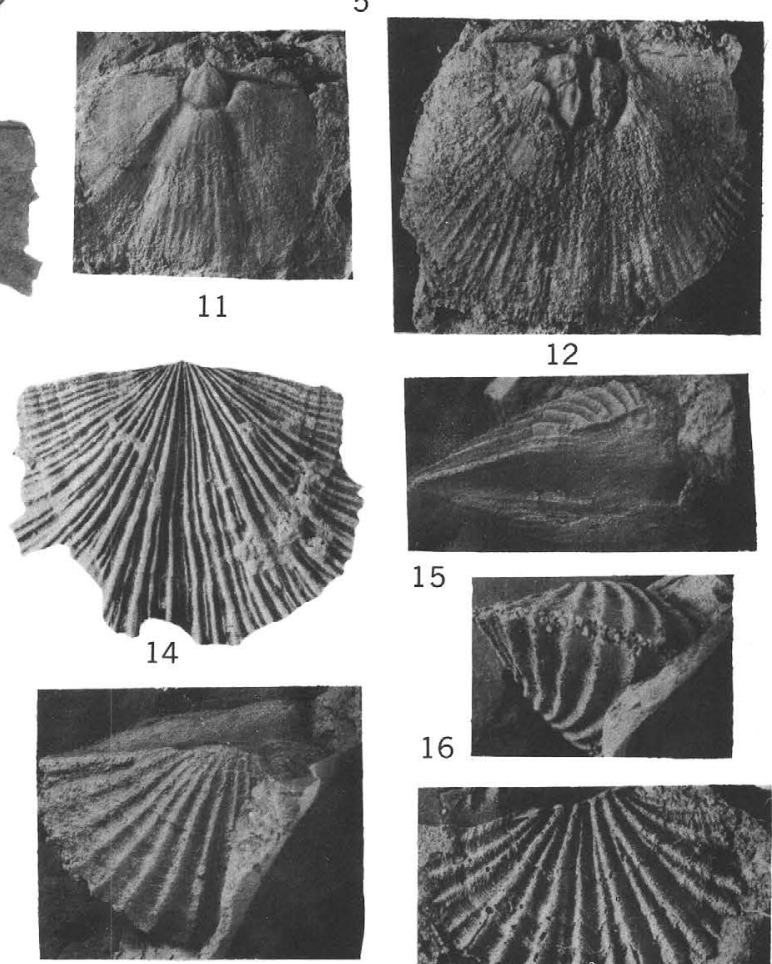

17
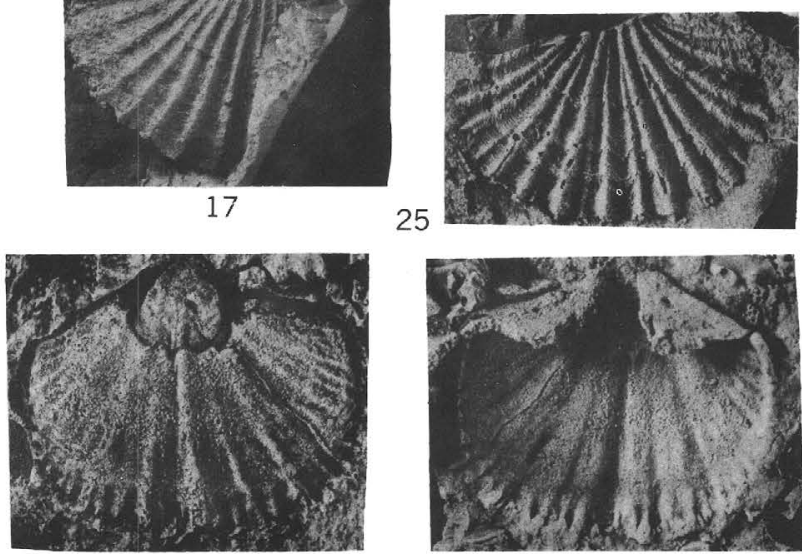

24

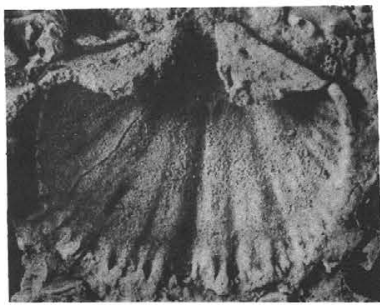

26

ORTHOSTROPHIA, SCHIZORAMMA, ORTHAMBONITES?, AND DOLERORTHIS 


\section{PLATE 2}

FIgURES 1-5. Dolerorthis ef D. hami (Amsden, 1951) (p. 7).

1-4. Base of Hobbstown Formation. USGS loc. 3479-SD, Spencer Lake quadrangle, Somerset County, Maine. $\times 2$.

1,2. Impressions of interior and exterior of pedicle valve. USNM 125795B, A.

3, 4. Impressions of interior and exterior of brachial valve. USNM 125794A, B.

5. Impression of interior of pedicle valve $(\times 3)$. USNM 160112. Harwood Mountain Formation. USGS loc. 5995-SD, Attean quadrangle, Somerset County, Maine.

6-8. Dolerorthis? sp. (p. 7).

Base of Hobbstown Formation.. USGS loc. 3479-SD, Spencer Lake quadrangle, Somerset County, Maine. $\times 2$.

6. Impression of interior of pedicle valve. USNM $125800 \mathrm{~B}$.

7,8. Latex replica and impression of exterior of pedicle valve. USNM $125800 \mathrm{C}$.

9-17. Ptychopleurella sp. (p. 7).

Base of Hobbstown Formation. USGS loc. 3479-SD, Spencer Lake quadrangle, Somerset County, Maine.

9 , 11. Latex replica and impression of exterior of brachial valve $(\times 2)$. USNM 125801A.

10. Latex replica of exterior of pedicle valve (posterior view $\times 3$ ). USNM 125804 .

12, 13. Impression and latex replica of interior of pedicle valve $(\times 2)$. USNM $125802 \mathrm{~A}$.

14, 16. Impression and latex replica of exterior of pedicle valve $(\times 2)$. USNM $125803 \mathrm{~B}$.

15. Latex replica and impression of interior of brachial valve $(\times 2)$. USNM 125801B.

18-22. Valcourea sp. (p. 8).

Kennebec Formation. USGS loc. 4317-CO, Brassua Lake quadrangle, Somerset County, Maine.

18. Latex replica of exterior (posterior view $\times 2$ ). USNM 125751.

19, 21. Impression of interior of brachial and pedicle valves $(\times 2)$. USNM $125752 \mathrm{C}$.

20,22 . Impression of exterior of pedicle and brachial valves $(\times 1)$. USNM $125750 \mathrm{~B}, \mathrm{~A}$.

23-27. Resserella sp. (p. 9).

Base of Hobbstown Formation. USGS loc. 3479-SD, Spencer Lake quadrangle, Somerset County, Maine. $\times 2$.

23. Impression of exterior of pedicle valve. USNM 125772A.

24. Latex replica of exterior of pedicle valve. USNM $125774 \mathrm{~A}$.

25. Impressions of interior of pedicle valve. USNM $125774 \mathrm{~B}$.

26,27 . Impressions of exterior and interior of brachial valve. USNM 125773B, A.

28-32. Isorthis sp. 1 (p. 10).

Base of Hobbstown Formation. USGS 3479-SD, Spencer Lake quadrangle, Somerset County, Maine. $\times 2$.

28, 29. Impression and latex replica of interior of brachial valve. USNM 125828 .

30,31 . Impressions of interior and exterior of brachial valve. USNM 125829A, B.

32. Impression of interior of pedicle valve. USNM 125827.

33-35. Isorthis $\mathrm{sp.} 2$ (p. 10).

33. Impression of interior of brachial valve $(\times 3)$. USNM 125831A. Hardwood Mountain Formation. USGS loc. 3495-SD, Spencer Lake quadrangle, Somerset County, Maine.

34, 35. Impressions of exterior and interior of pedicle valve $(\times 3)$. USNM 125826B, A. Parker Bog Formation. USGS loc. 3487-SD, Spencer Lake quadrangle, Somerset County, Maine. 
GEOLOGICAL SURVEY
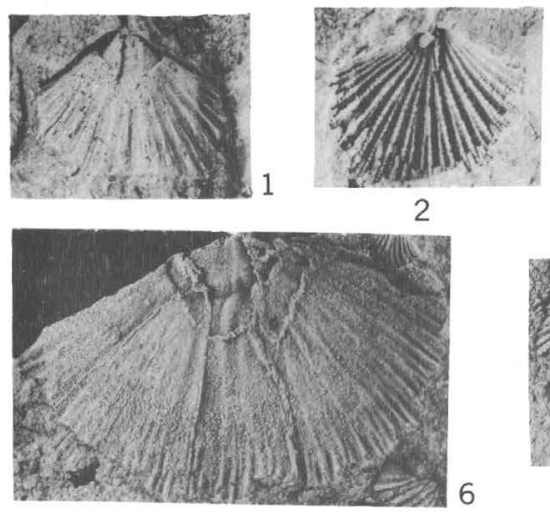

2
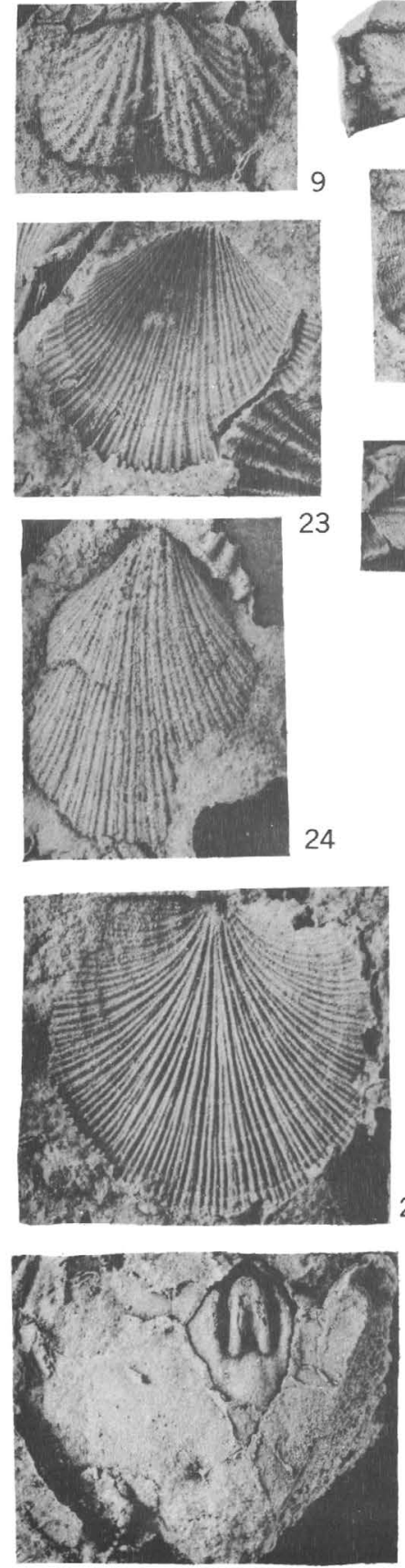

28
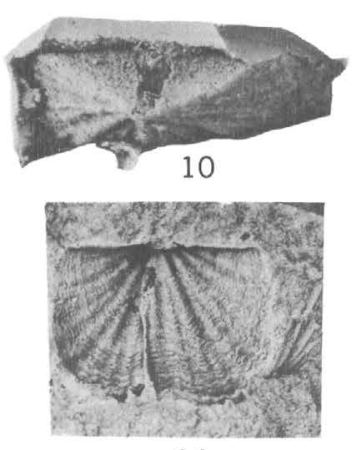

14

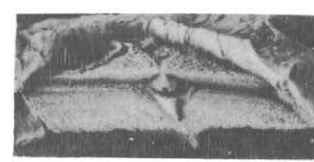

18

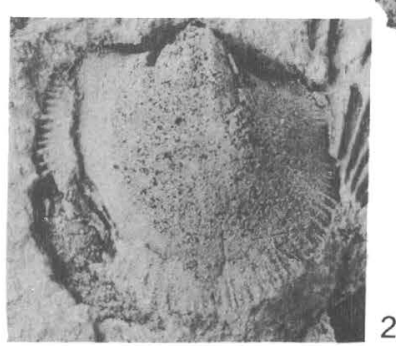

25

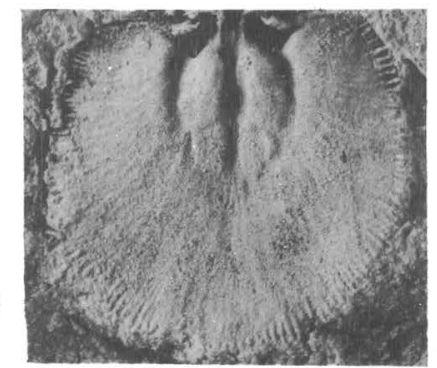

27

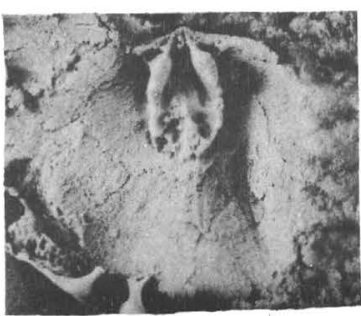

29

15

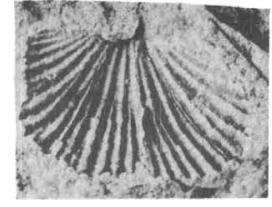

4
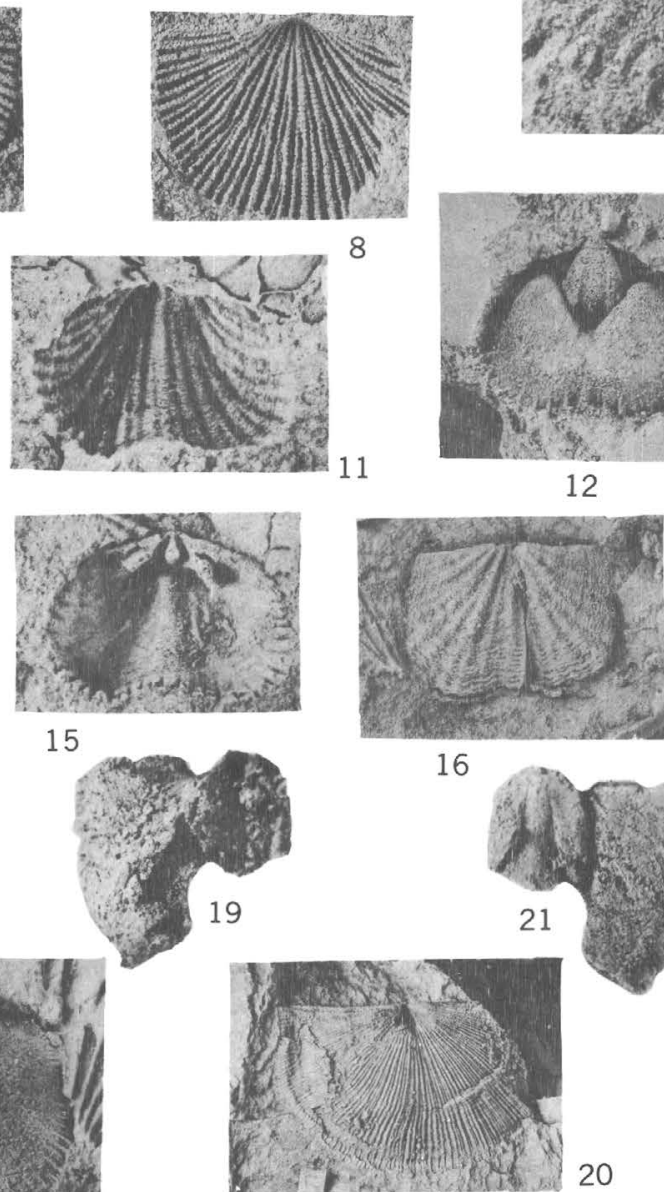

16

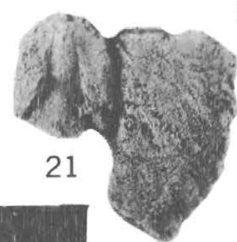

17

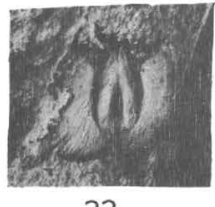

33

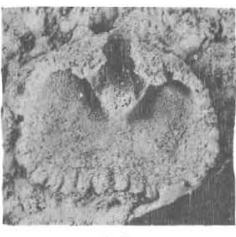

13
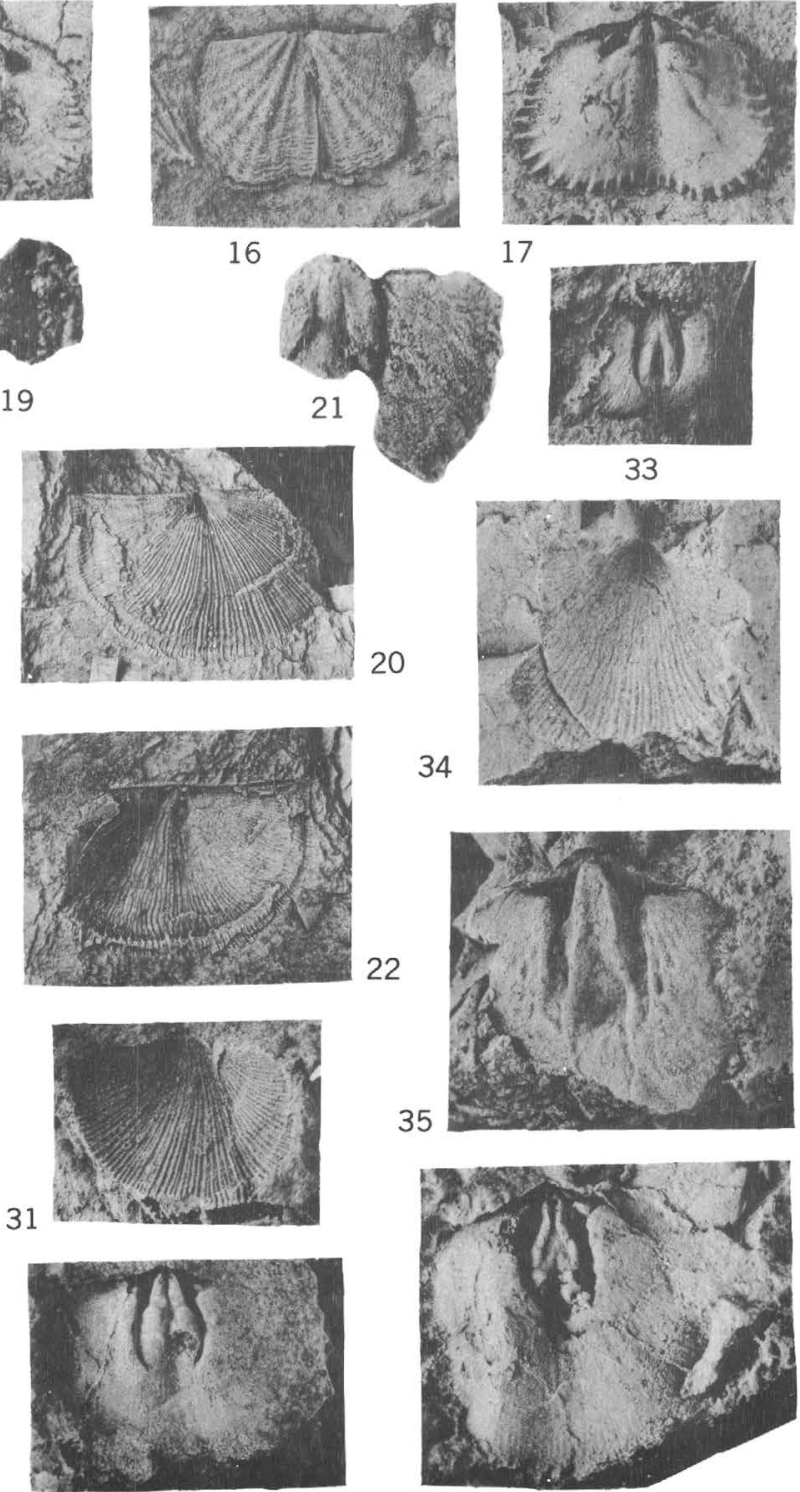

30

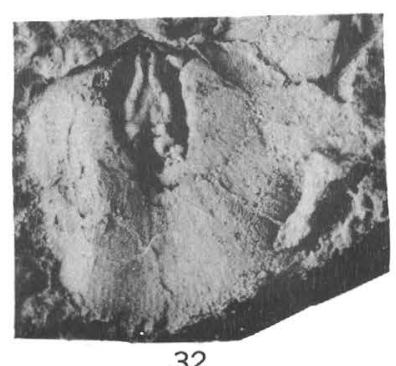

32

DOLERORTHIS, DOLERORTHIS?, PTYCHOPLEURELLA, VALCOUREA, RESSERELLA, AND ISORTHIS 


\section{PLATE 3}

Figures 1-16. Isorthis sp. 3 (p. 10).

Hardwood Mountain Formation. Attean quadrangle, Somerset County, Maine. $\times 2$.

1. Impression of interior of pedicle valve. USNM 160113. USGS loc. 5587-SD.

2. Impression of interior of brachial valve. USNM 160114. USGS loc. 5583-SD.

3. Impression of interior of brachial valve. USNM 160115. USGS loc. 5586-SD.

4. Impression of interior of pedicle valve. USNM 160116. USGS. loc. 5586-SD.

5-8, 10. Impression of interior: anterior-riew, side view, pedicle view, brachial view, and posterior view (pedicle valve up). USNM 160117. USGS loc. 5583-SD.

9. Impression of interior of pedicle valve. USNM 160118. USGS loc. 5583-SD.

11-16. Impression of interior: brachial view, pedicle view, side view (pedicle valve to right), side view (pedicle valve to left), posterior view (pedicle valve up), and anterior view (pedicle valve up). USNM 160119. USGS loc. 5583-SD.

17. Isorthis cf. I. perelegans (Hall, 1859) (p. 11).

Impression of interior of brachial valve $(\times 2)$, USNM 125813. Beck Bond Limestone. USGS loc. 3499-SD, Spencer Lake quadrangle, Somerset County, Maine.

18-20. Levenea sp. (p. 11).

Beck Pond Limestone. USGS loc. 3499-SD, Spencer Lake quadrangle, Somerset County, Maine. $\times 2$.

18, 19. Impression of interior of pedicle valve. USNM 125812, $125811 \mathrm{~B}$.

20. Impression of interior of brachial valve. USNM 125814.

21. Unidentified orthoid (p. 11).

Impression of interior of pedicle valve $(\times 4)$. USNM 126473. Lobster Mountain volcanics. USGS loc. 3280-SD, North East Carry quadrangle, Piscataquis County, Maine.

22. Dicaelosia sp. (p. 11).

Exterior of brachial valve $(\times 3)$. USNM 125810. Beck Pond Limestone. USGS loc. 3499-SD, Spencer Lake quadrangle, Somerset County, Maine.

23-25. Discomyorthis musculosa solaris (Clarke, 1907) (p. 12).

Tomhegan Formation. USGS loc. 2750-SD, Brassua Lake quadrangle, Somerset, County, Maine. $\times 20$.

23. Latex replica of exterior of brachial valve. USNM 125808A.

24. Latex replica of interior of pedicle valve. USNM 125806.

25. Impression of interior of pedicle valve. USNM 125806. 
GEOLOGICAL SURVEY

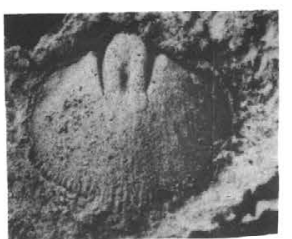

1

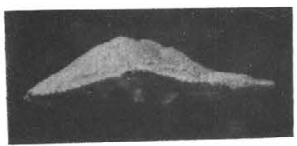

5

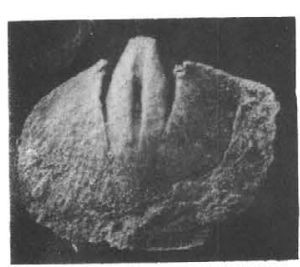

7

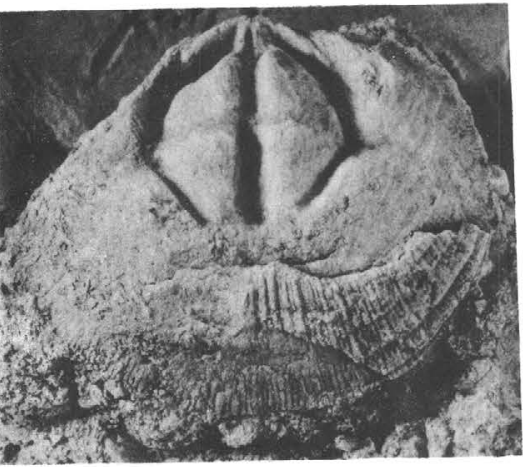

17
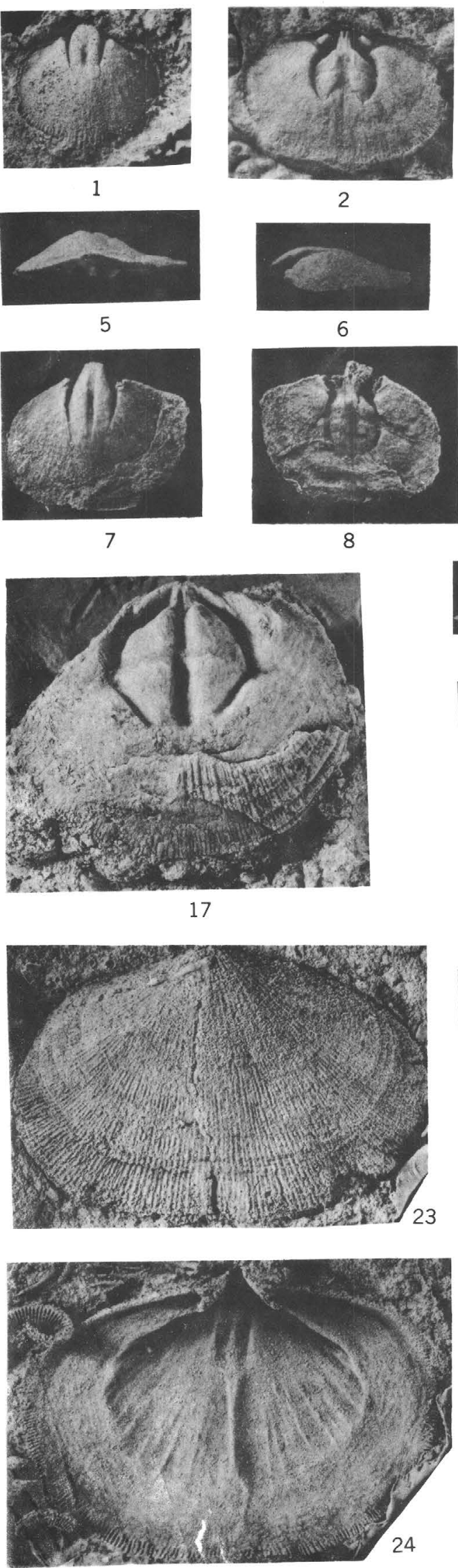

2

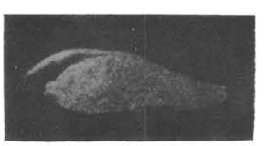

6

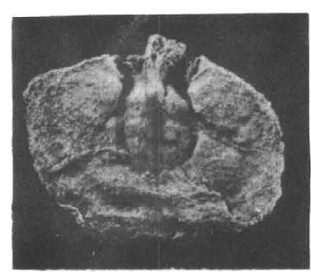

8

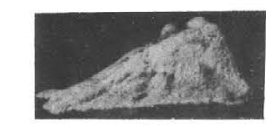

11

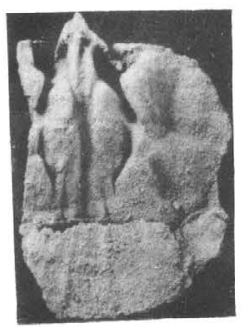

15

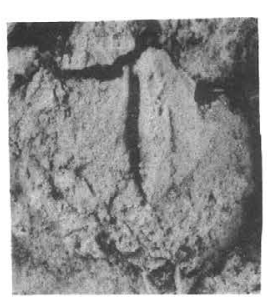

21

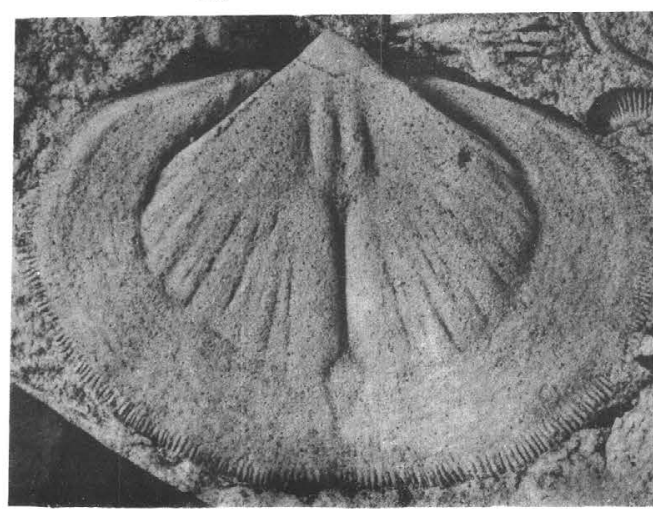

PROFESSIONAL PAPER 784 PLATE 3

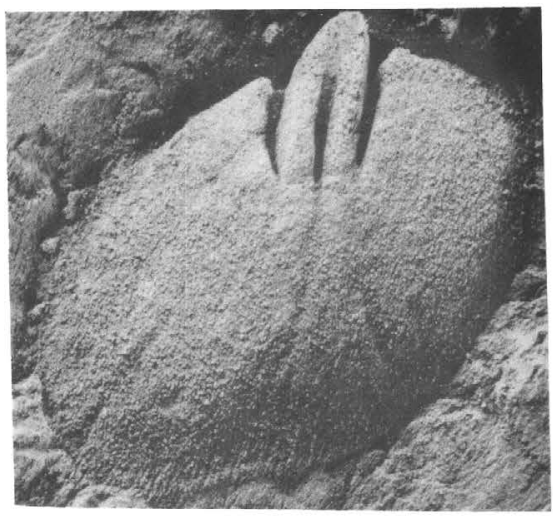

4

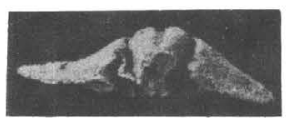

10

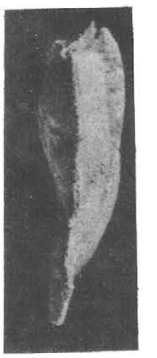

13

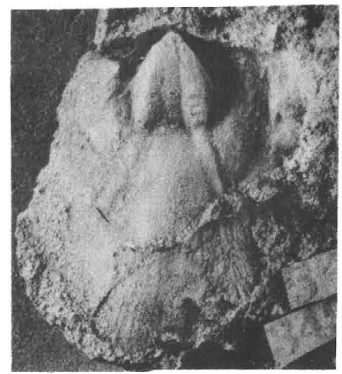

19

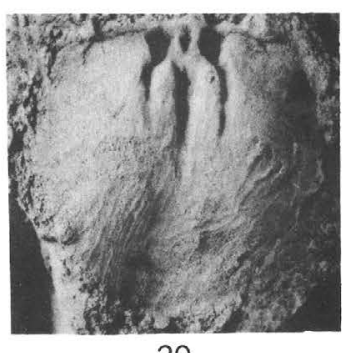

20

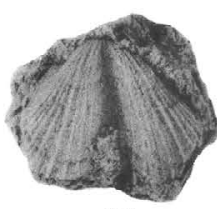

22 
PLATE 4

Figures 1-3. Discomyorthis musculosa solaris (Clarke, 1907) (p. 12).

Tomhegan Formation. USGS loc. 2750-SD, Brassua Lake quadrangle, Somerset County, Maine. $\times 2$.

1, 3. Latex replica and impression of interior of brachial valve. USNM $125809 \mathrm{~A}$.

2. Impression of interior of pedicle valve. USNM $125807 \mathrm{~B}$.

4, 5. Dalejina sp. 2 (p. 16).

Impression of interior and exterior of brachial valve $(X 3)$. USNM 125824B, A. Hardwood Mountain Formation. USGS loc. 3469-SD, Spencer Lake quadrangle, Somerset County, Maine.

6-9. Dalejina sp. 1 (p. 16).

Base of Hobbstown Formation. USGS loc. 3479-SD, Spencer Lake quadrangle, Somerset County, Maine. $\times 3$.

6, 8. Impression of exterior and interior of pedicle valve. USNM $125821 \mathrm{~B}, \mathrm{~A}$.

7, 9. Impression of interior and exterior of brachial valve. USNM $125822 B, A$.

10. Discomyorthis sp. (p. 13).

Impression of interior of pedicle valve $(\times 3)$. USNM 125823. Beck Pond Limestone. USGS loc. 3499-SD, Spencer Lake quadrangle, Somerset County, Maine.

11-18. Platyorthis planoconvexa (Hall, 1859) (p. 16).

Lower sandstone of Tarratine Formation, Somerset County, Maine.

11, 12. Impression and latex replica of interior of pedicle valve $(\times 2)$. USNM 125819. USGS loc. 3474-SD, Pierce Pond quadrangle.

13, 15. Latex replica of interior and exterior of brachial valve $(\times 2$, $\times 3)$. USNM 125820B, A. USGS loc. 2771-SD, Moosehead Lake quadrangle.

14, 17. Impression and latex replica of exterior of pedicle valve $(\times 2)$. USNM 125825A. USGS loc. 3474-SD, Pierce Pond quadrangle.

16, 18. Impressions of interior and exterior of brachial valve ( $X$ 2). USNM 125820B, A. USGS loc. 2771-SD, Moosehead Lake quadrangle. 
GEOLOGICAL SURVEY

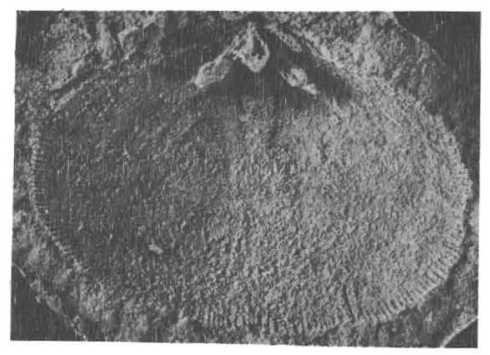

1

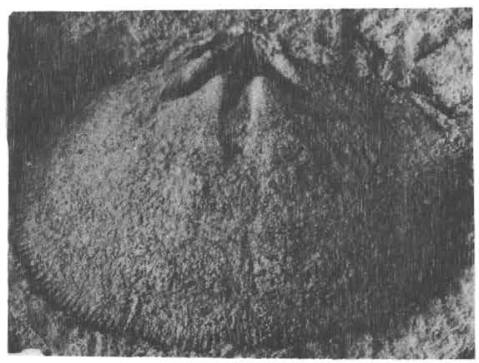

3

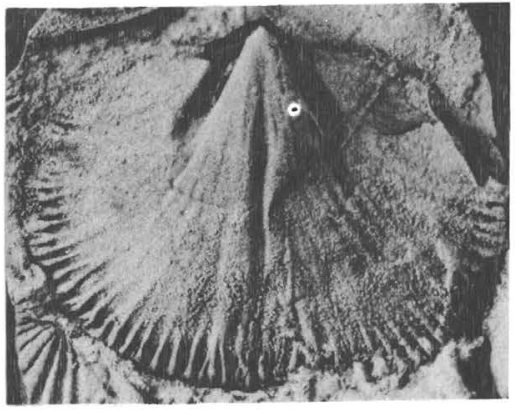

11

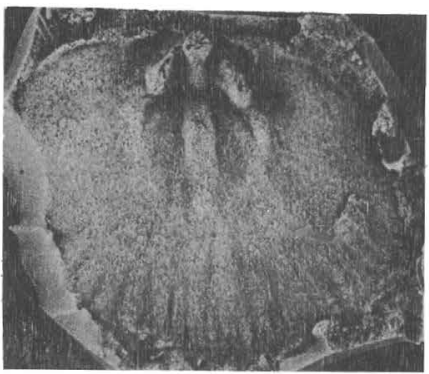

13

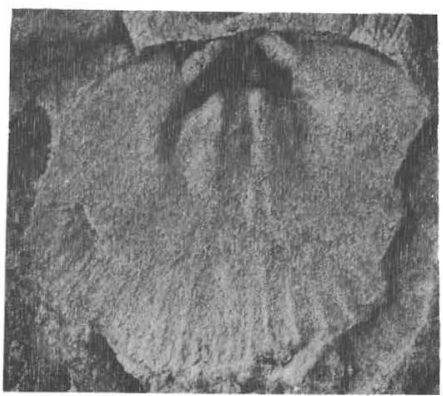

16

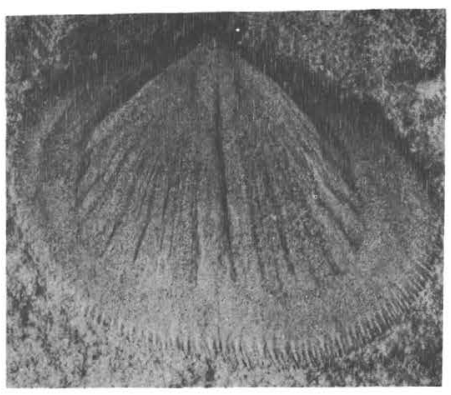

2

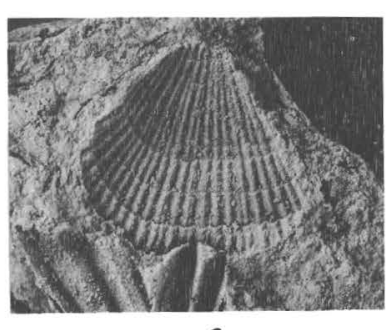

6

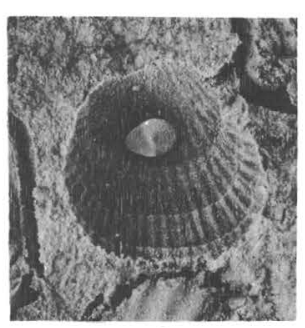

9

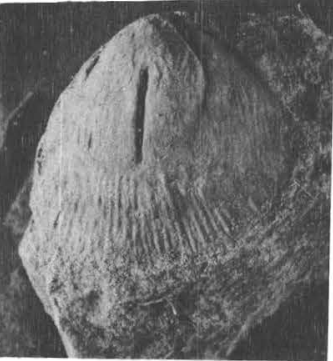

10

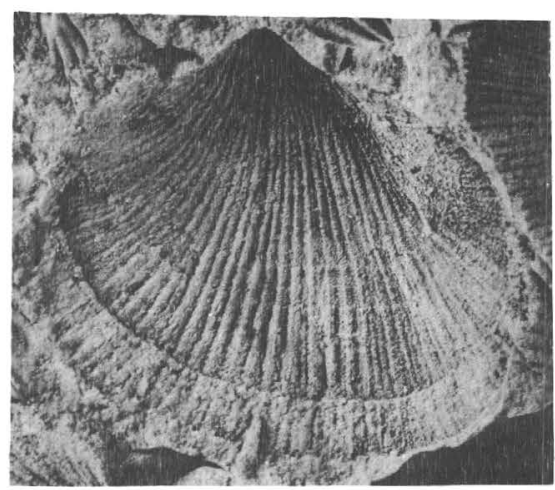

14

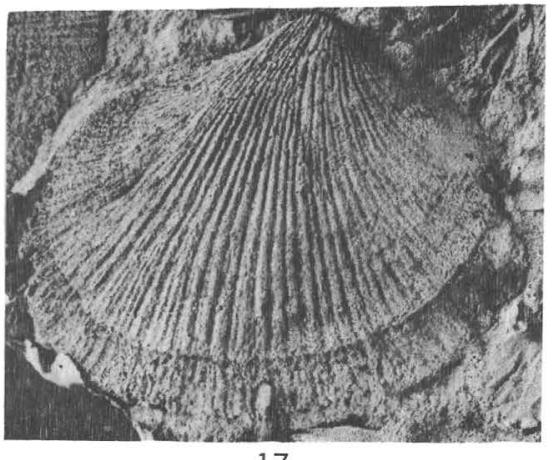

17

PROFESSIONAL PAPER 784 PLATE 4

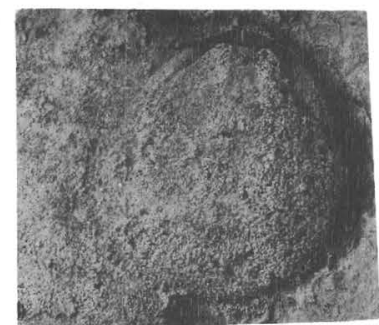

4

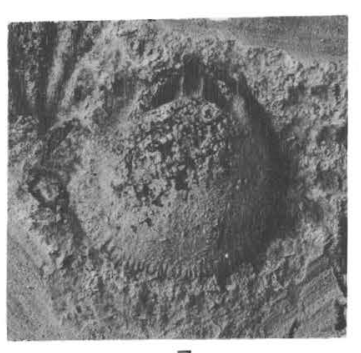

7

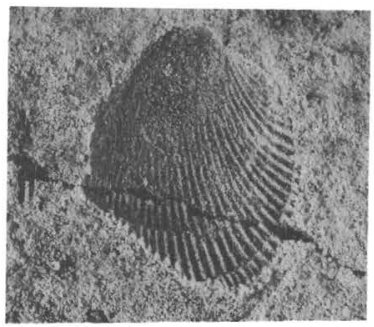

5

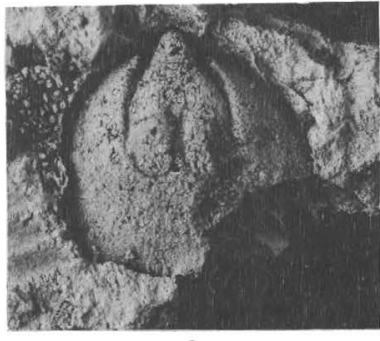

8

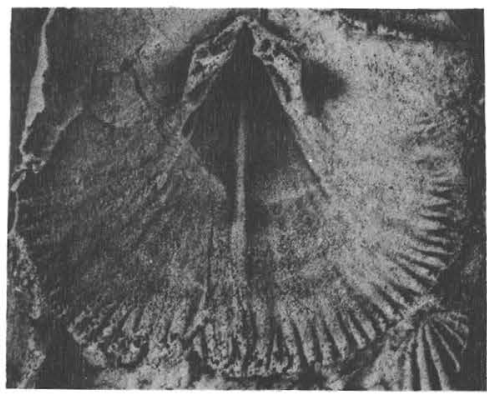

12

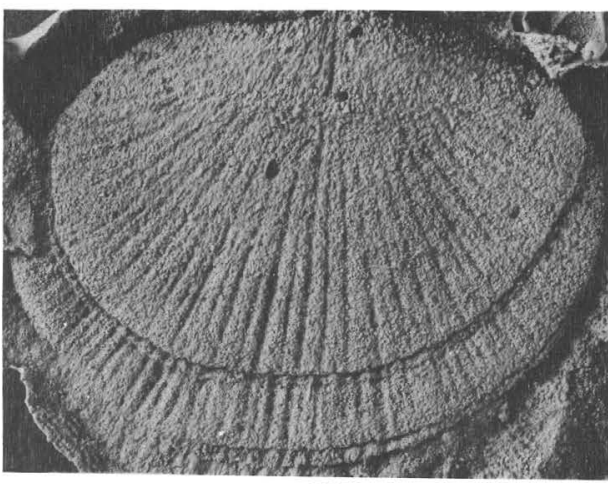

15

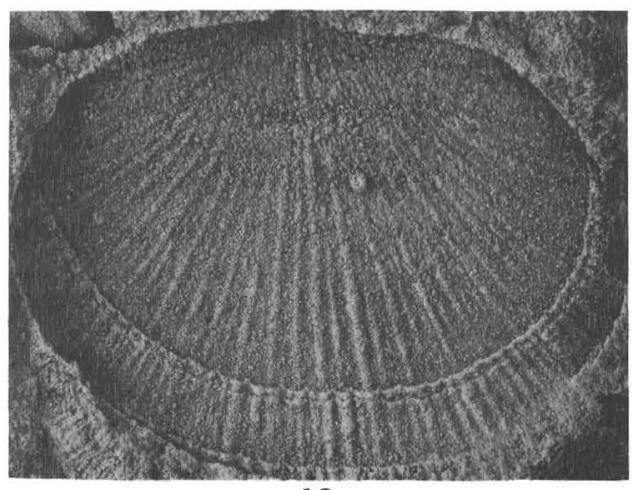

18

DISCOMYORTHIS, DALEJINA, AND PLATYORTHIS 


\section{PLATE 5}

Figures 1-11. Salopina hitcheocki Walmsley, Boucot, and Harper, 1969 (p. 18).

1, 2. Latex replica and impression of interior of brachial valve $(\times 3)$. Lower sandstone of Tarratine Formation. USGS loc. 2872-SD, Pierce Pond quadrangle, Somerset County, Maine. USNM 125783A.

3, 4. Latex replica and impression of exterior of brachial valve (X 3). Lower sandstone of Tarratine Formation. USGS loc. 2872-SD, Pierce Pond quadrangle, Somerset County, Maine. USNM 125783B.

5. Latex replica of interior of pedicle valve $(x 3)$. Lower sandstone of Tarratine Formation. USGS loc. 2743-SD, Moosehead Lake quadrangle, Somerset County, Maine. USNM 125798A.

6. Impression of interior of pedicle valve $(\times 3)$. Seboomook Formation. USGS loc. 2884-SD, Chesuncook quadrangle, Piscataquis County, Maine. USNM 125793A.

7, 8. Latex replica and impression of interior of brachial valve $(\times 3)$. Tarratine Formation. USGS loc. 2861-SD, North East Carry quadrangle, Somerset County, Maine. Holotype, USNM 125782B.

9. Impression of interior of pedicle valve $(\times 3)$. Lower sandstone of Tarratine Formation. USGS loc. 2705-SD, Brassua Lake quadrangle, Somerset County, Maine. USNM $125781 \mathrm{~B}$.

10, 11. Impression and latex replica of exterior of brachial valve $(\times 3)$. Tarratine Formation. USGS loc. 2861-SD, North East Carry quadrangle, Somerset County, Maine. Holotype, USNM $125782 \mathrm{~A}$.

12-14. Gypidula sp. 1 (p. 19).

Hardwood Mountain Formation, USGS loc. 3488-SD, Spencer

Lake quadrangle, Somerset County, Maine.

12. View of inner crural plates and hinge plate $(\times 3)$. USNM 126508.

13, 14. Side view of spondylium $(\times 3)$ and exterior of pedicle valve $(\times 2)$. USNM $126509 \mathrm{~A}$.

15-23. Gypidula sp. 2 (p. 19).

15-19. Exterior: side, brachial, pedicle, posterior, and anterior views $(X 1)$. Hardwood Mountain Formation. USGS loc. 2728-SD, Spencer Lake quadrangle, Somerset County, Maine. USNM 125840.

20-23. Anterior (brachial valve above), opposite side, and posterior views $(X 2)$. Hardwood Mountain Formation. USGS loc. 5587-SD, Attean quadrangle, Somerset County, Maine. USNM 160120. 
GEOLOGICAL SURVEY

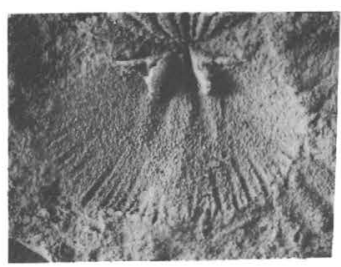

1

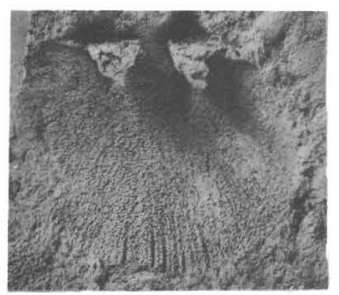

5

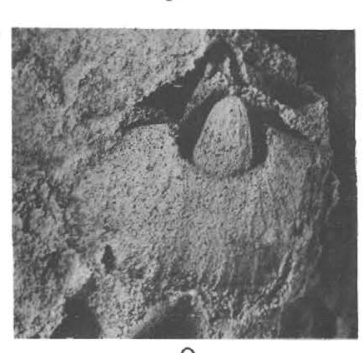

9
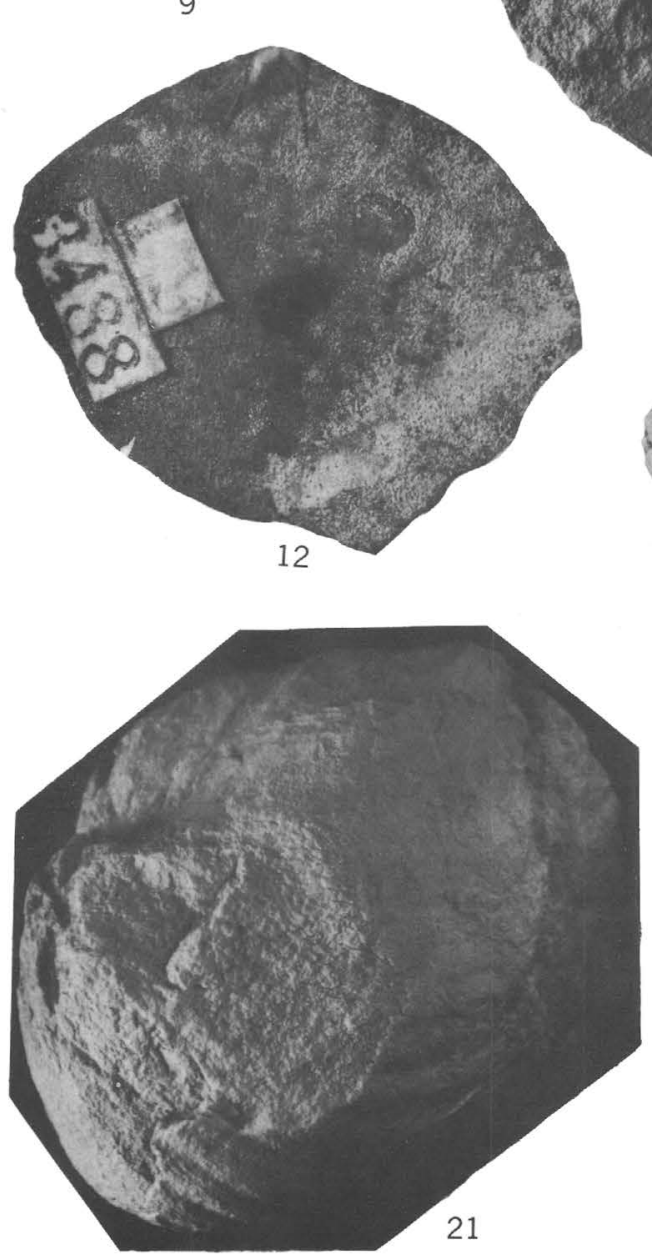

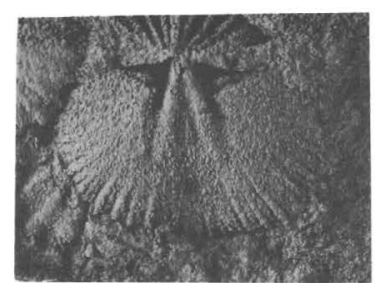

2

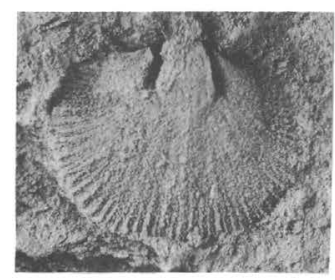

6
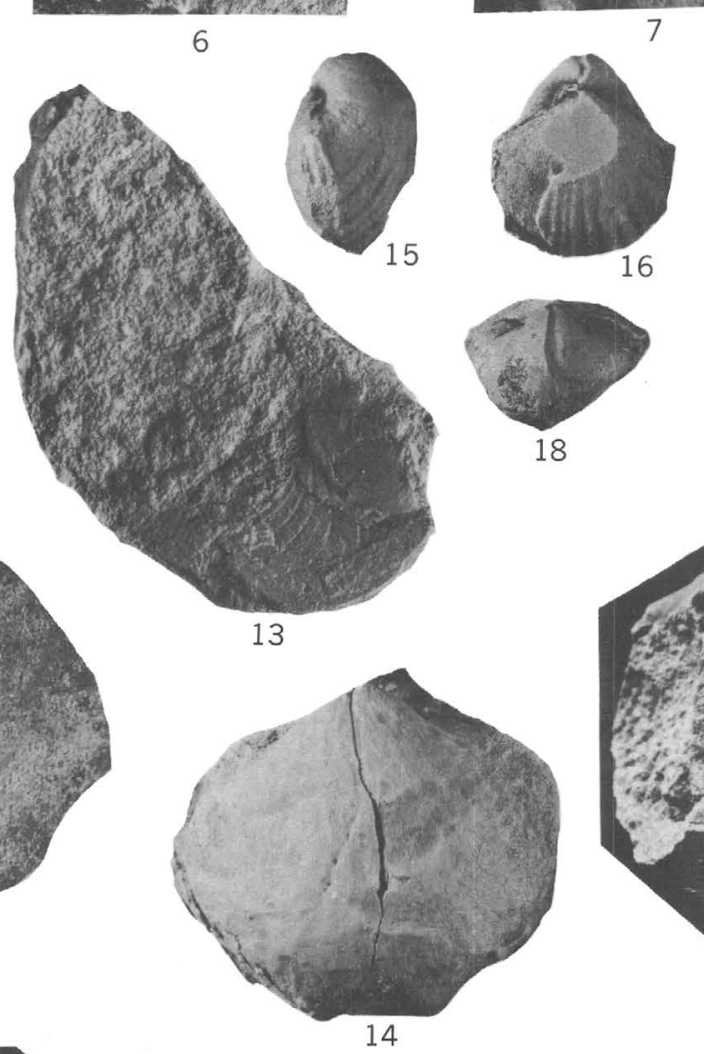

3

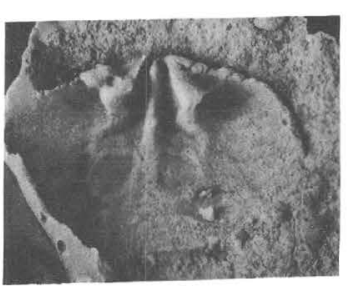

PROFESSIONAL PAPER 784 PLATE 5
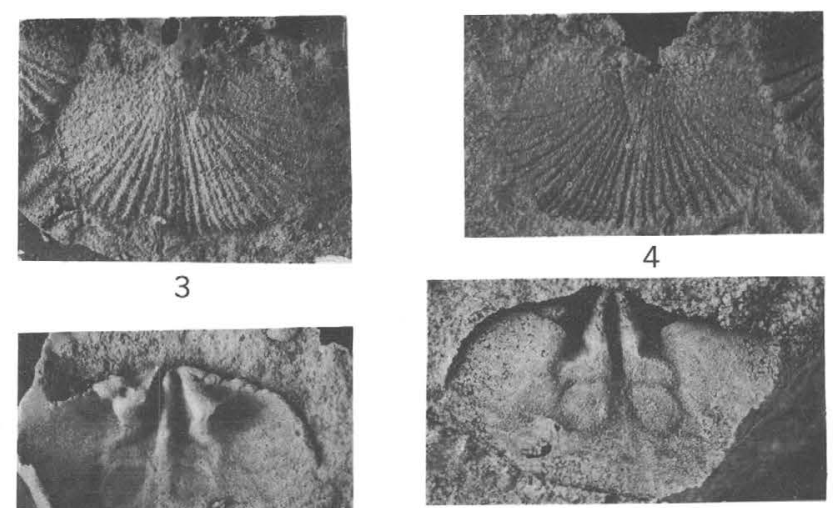

8

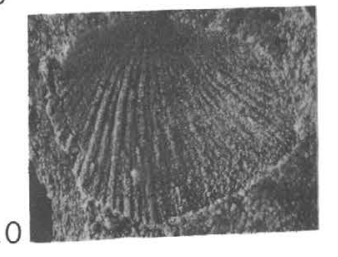

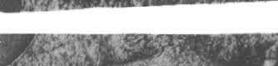

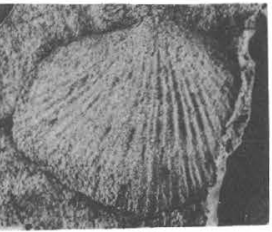

18
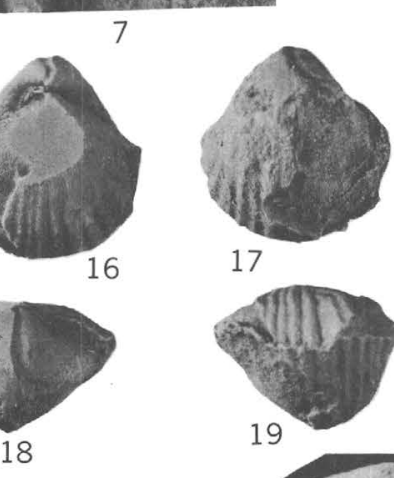

17
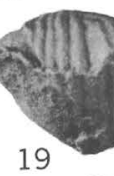
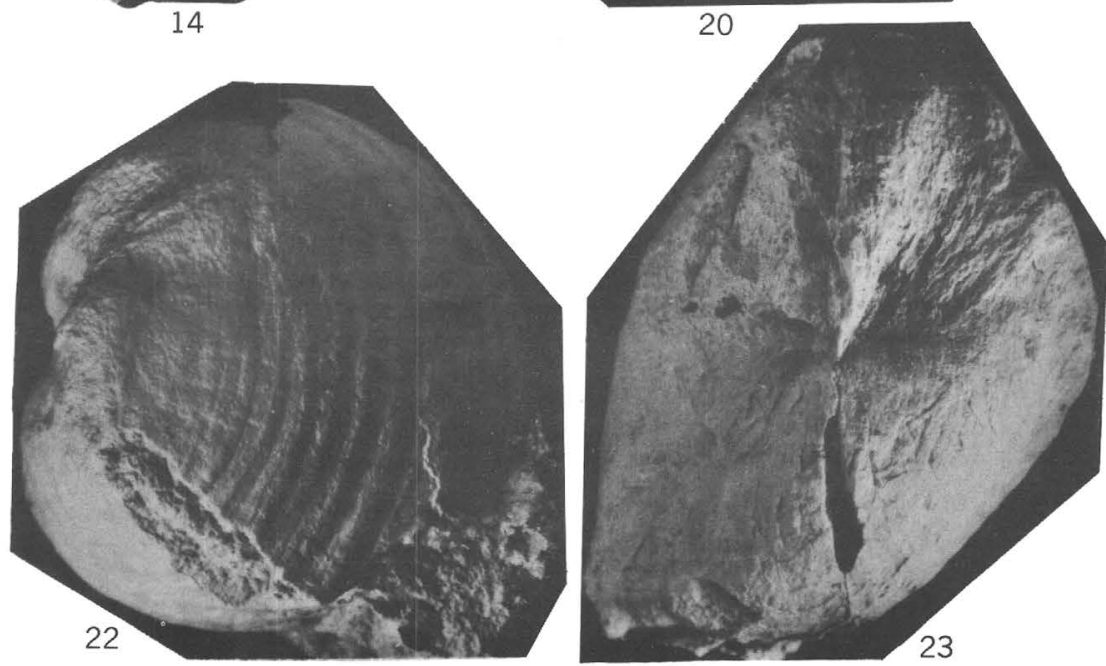

SALOPINA AND GYPIDULA 


\section{PLATE 6}

Figures 1, 2. Gypidula sp. 2? (p. 19).

Views of silicified cardinalia $(\times 1)$. USNM 125842. Hardwood Mountain Formation. USGC loc. 3485-SD, Spencer Lake quadrangle, Somerset County, Maine.

3-8. Sieberella beckensis Boucot, n. sp. (p. 20).

Beck Pond Limestone. USGS loc. 3499-SD, Spencer Lake quadrangle, Somerset County, Maine.

$3,6,8$. Exterior $(\times 1)$, side $(\times 2)$, and posterior $(\times 2)$ views of pedicle valve. Holotype, USNM 125841A.

4. Exterior of brachial valve $(\times 1)$. USNM 125838B.

5. Side view of spondylium $(\times 3)$. USNM 125837 .

7. Cross section of brachial valve $(\times 3)$. Note lyre-shaped cross section of brachial lamellae. USNM 125839.

9, 10. Pentamerus? sp. (p. 20).

Lime-silicate hornfels of Early Silurian age. USGS loc. 3475-SD, Limestone Hill, Stratton quadrangle, Somerset County, Maine.

9. Impression of interior of pedicle valve $(\times 2)$. USNM 125835 .

10. Partly exfoliated pedicle valve $(\times 1)$. USNM $125836 \mathrm{~B}$.

11. Sowerbyites? sp. (p. 20).

Latex replica of exterior of brachial valve $(x 3)$. USNM 126152A. Kennebec Formation. USGS loc. 4317-CO, Brassua Lake quadrangle, Somerset County, Maine.

12-16. Leptaena "rhomboidalis" (Wilckens, 1769) (p. 20).

Spencer Lake quadrangle, Somerset County, Maine.

12. Exterior of pedicle valve $(X 2)$. USNM 126141B. Beck Pond Limestone. USGS loc. 3499-SD.

13, 15. Impression $(X 1)$ and latex replica $(X 2)$ of interior of brachial valve. USNM 126146A. Beck Pond Limestone. USGS loc. 3497-SD.

14, 16. Impressions of interior and exterior of pedicle valve ( $X$ 1). USNM 126127B, A. Base of Hobbstown Formation. USGS loc. 3479-SD.

17-19. Stropheodonta cf. S. demissa (Conrad, 1842) (p. 21).

Tomhegan Formation. Brassua Lake quadrangle, Somerset County, Maine.

17. Latex replica of exterior of brachial valve $(\times 3)$. USNM 126145B. USGS loc. 2750-SD.

18, 19. Latex replica of exterior and impression of interior of brachial valve $(\times 2)$. USNM 126144A. USGS loc. 2820-SD.

20-23. aff. Stropheodonta sp. (p. 21).

Tomhegan Formation. Brassua Lake quadrangle, Somerset County, Maine.

10. Latex replica of exterior of pedicle valve $(X 2)$. USNM 126153A. USGS loc. 2820-SD.

21. Impression of interior of pedicle valve $(\times 1)$. USNM 126126A. USGS loc. 2750-SD.

22. Latex replica of interior of pedicle valve $(X 3)$. USNM 126125. USGS loc. 2820-SD.

23. Latex replica of exterior of brachial valve (posterior view $\times 3)$. USNM 126126B. USGS loc. 2820-SD. 
GEOLOGICAL SURVEY
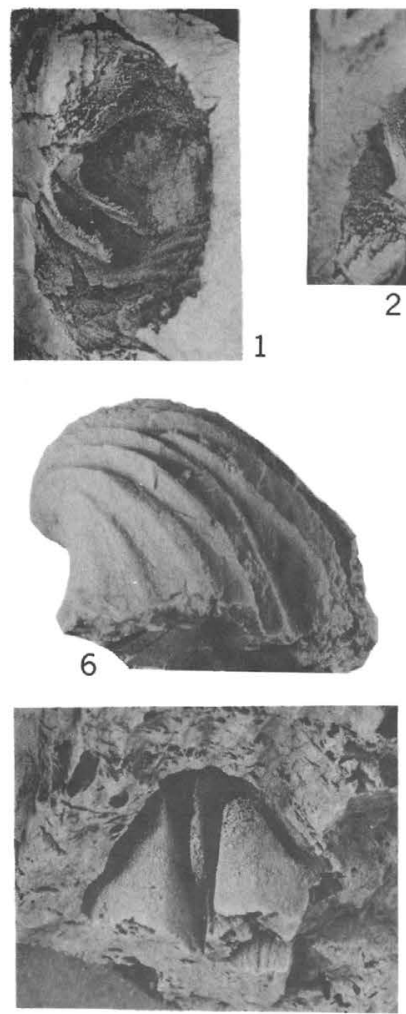

9

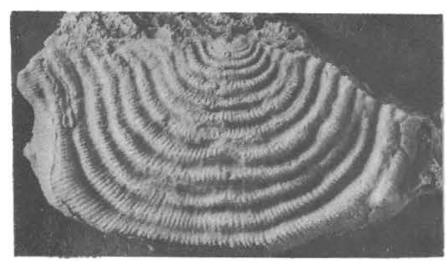

12

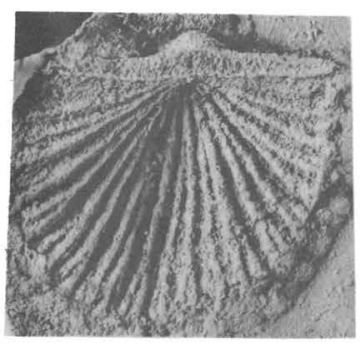

17

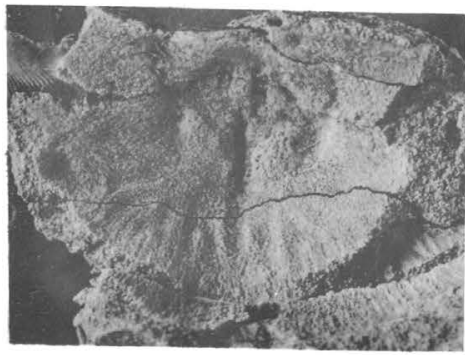

19

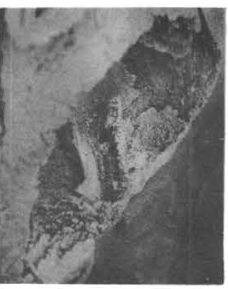

2
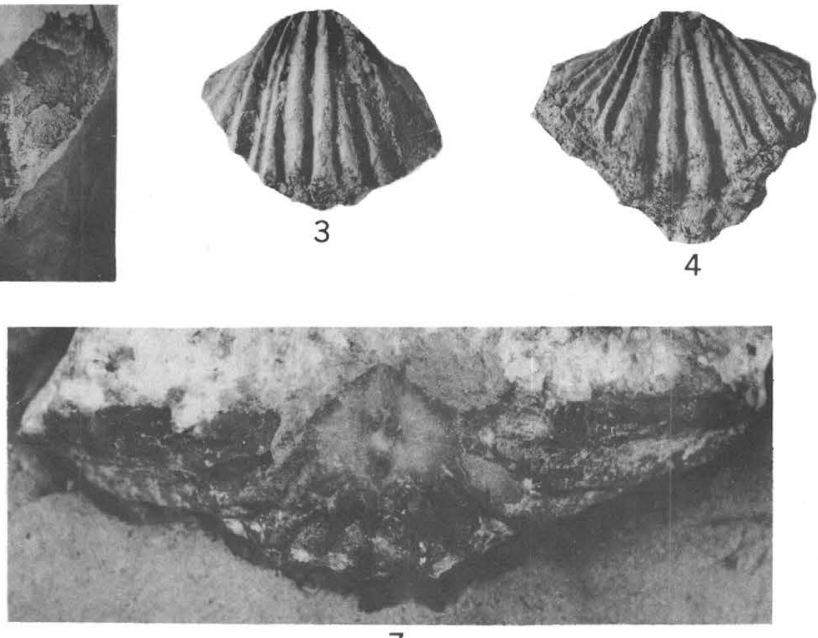

4

PROFESSIONAL PAPER 784 PLATE 6

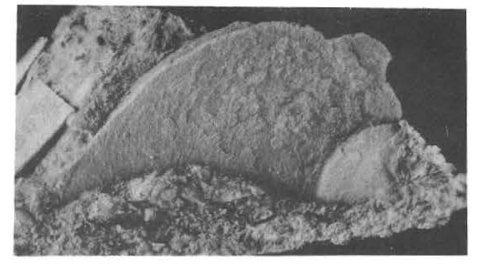

5

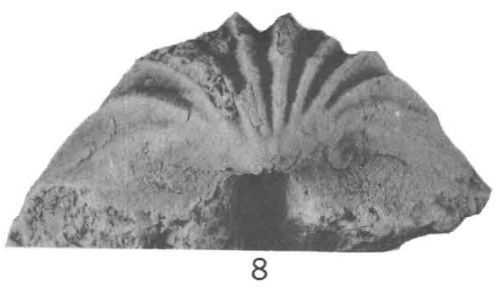

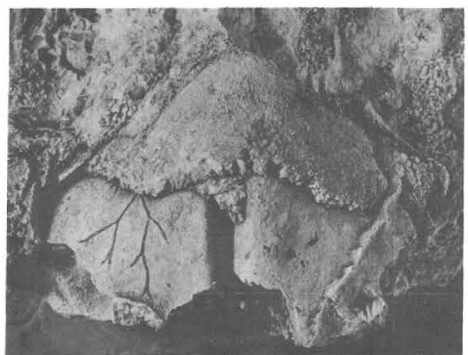

10

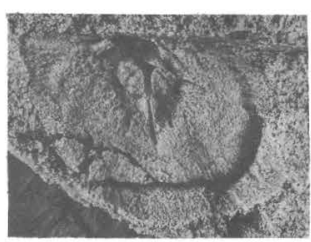

13

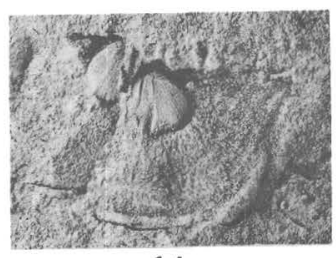

14

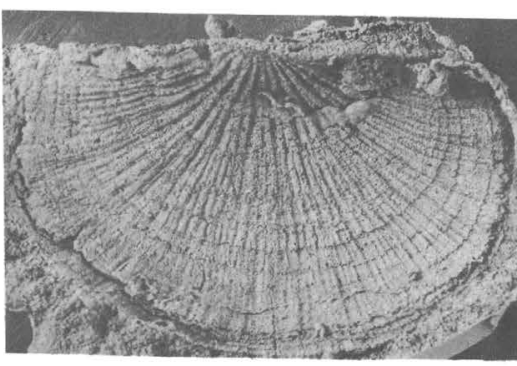

18

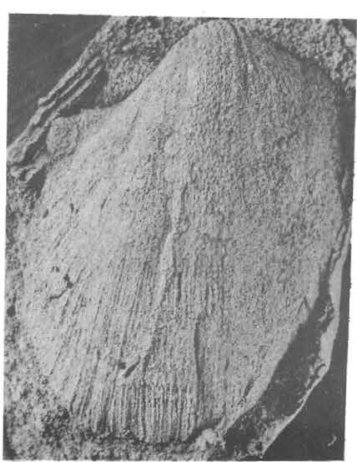

20

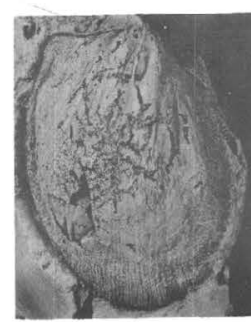

21

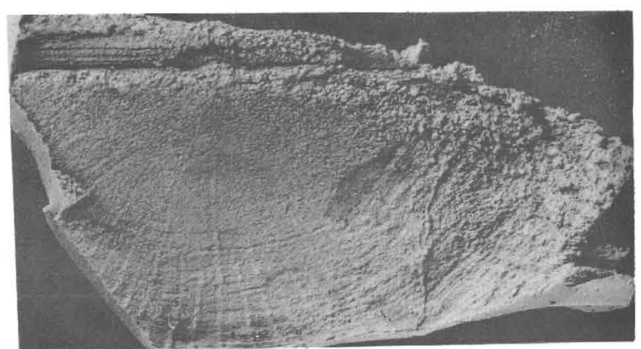

11

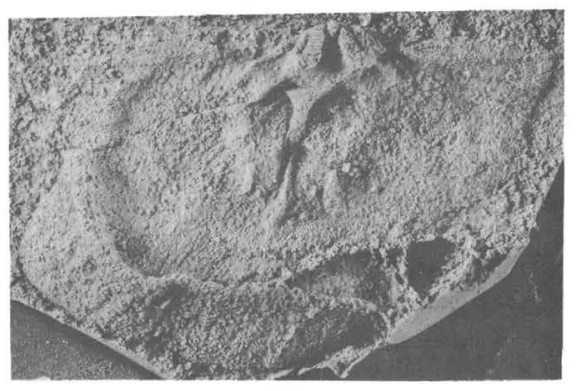

15

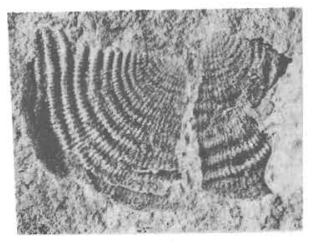

16

GYPIDULA, SIEBERELLA, PENTAMERUS?, SOWERBYITES? LEPTAENA, AND STROPHEODONTA 


\section{PLATE 7}

Figures 1-9. Leptostrophia cf. L. magnifica (Hall, 1857) (p. 21).

Lower sandstone of Tarratine Formation. Somerset County, Maine.

1, 3. Impression and latex replicas of interior of pedicle valve ( $X$ 1). USNM 126121. USGS loc. 2813-SD, Pierce Pond quadrangle.

4, 8. Latex replica and impression of interior of brachial valve ( $\times$ 4). USNM 126158B. USGS loc. 2813-SD, Pierce Pond quadrangle.

5. Latex replica of exterior (posterior brachial view $\times 1$ ). USNM 126159. USGS loc. 2705-SD, Brassua Lake quadrangle.

6. Latex replica of interior of brachial valve $(\times 2)$. USNM 126142. USGS loc. 2813-SD, Pierce Pond quadrangle.

7. Impression of interior of pedicle valve $(\times 1)$. USNM 126122. USGS loc. 2813-SD, Pierce Pond quadrangle.

9. Impression of interior of pedicle valves $(\times 1)$. USNM 126123. USGS loc. 2705-SD, Brassua Lake quadrangle.

10, 11. Leptostrophia? sp. (p. 22).

Parker Bog Formation. USGS loc. 3477-SD, Pierce Pond quadrangle, Somerset County, Maine.

10. Impression of interior of brachial valve $(X 3)$. USNM 126120 .

11. Impression of interior of pedicle valve $(X 2)$. USNM $126147 \mathrm{~B}$.

12, 13. Leptostrophia sp. or Protoleptostrophia sp. (p. 22).

Latex replica and impression of interior of pedicle valve $(X 1)$. USNM 126118A. Seboomook Formation. USGS loc. 2857-SD, Brassua Lake quadrangle, Somerset County, Maine. 
GEOLOGICAL SURVEY

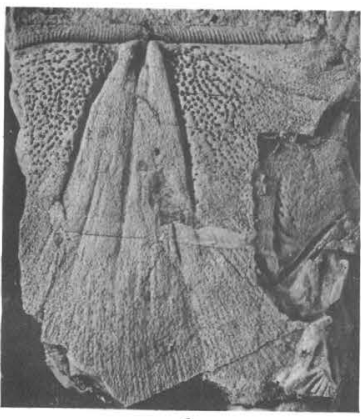

1

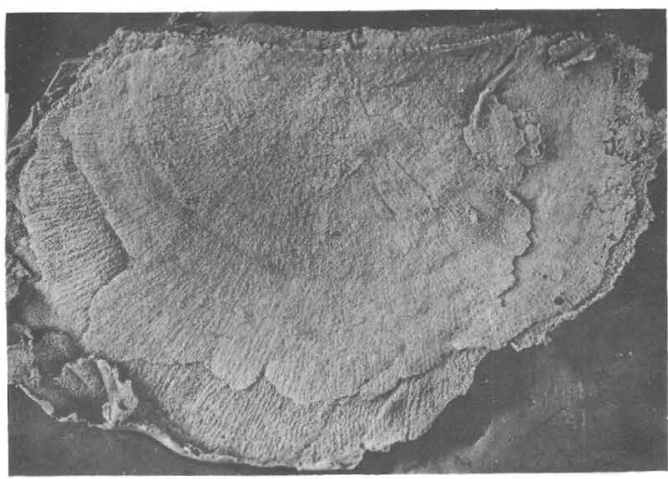

5

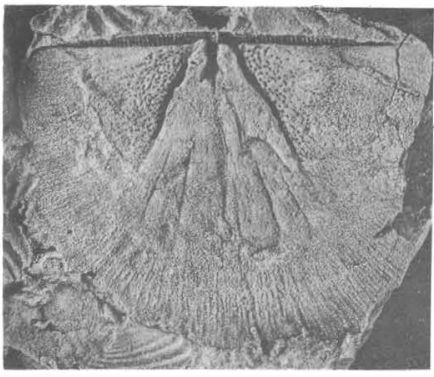

7

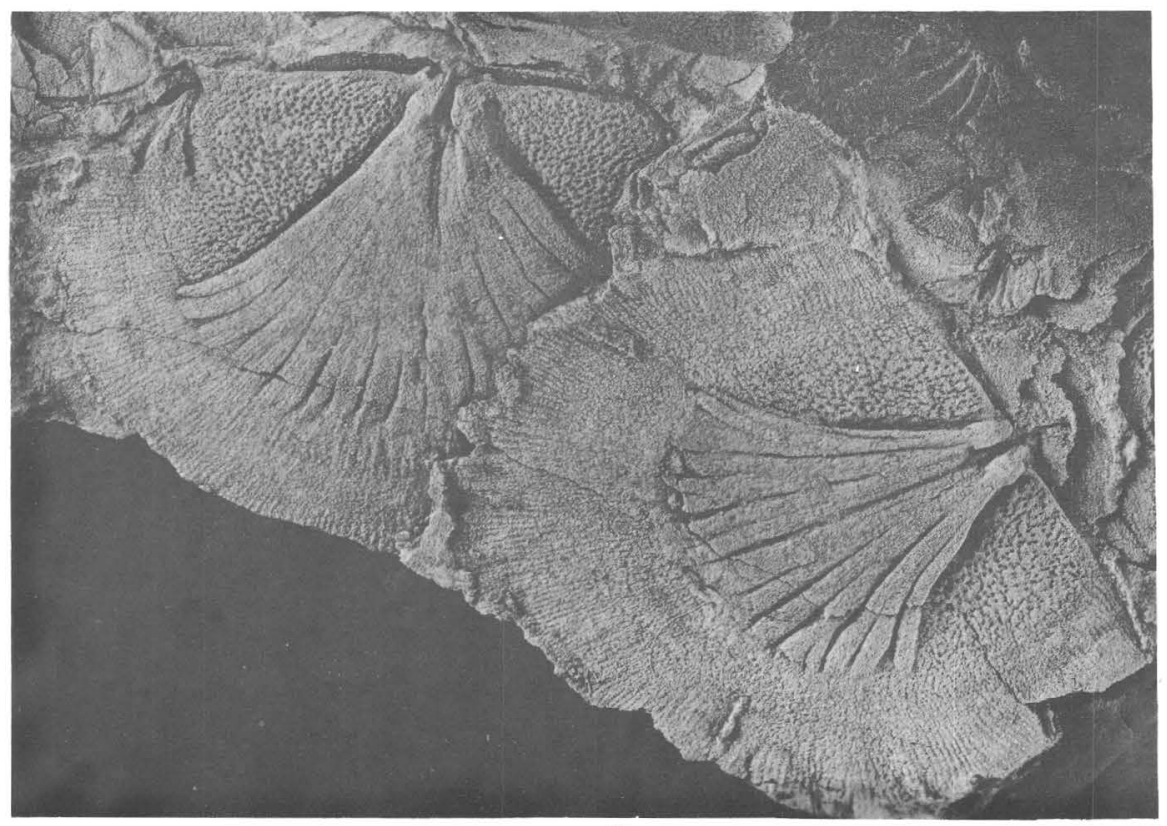

9

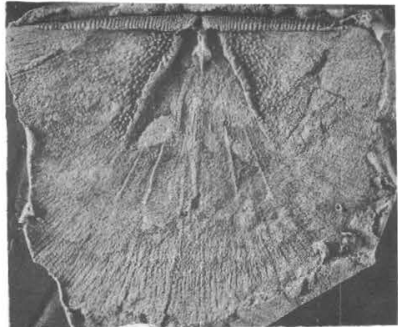

3

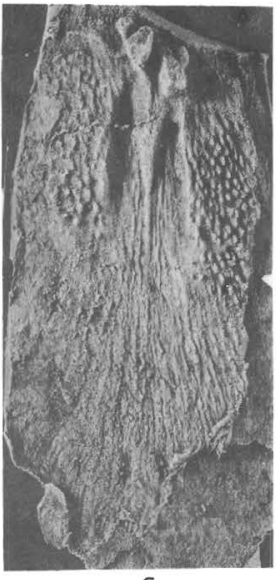

6

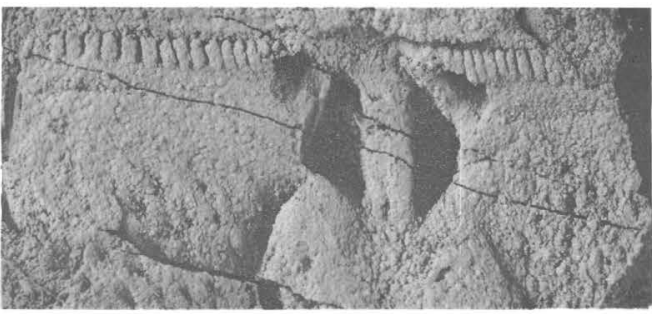

8
PROFESSIONAL PAPER 784 PLATE 7
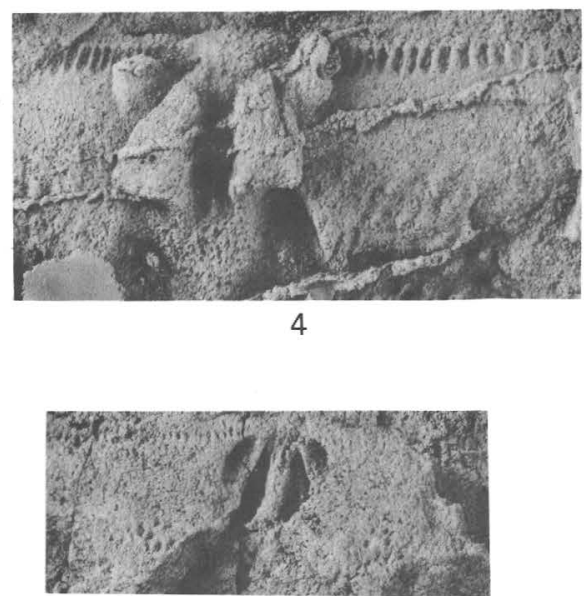

10

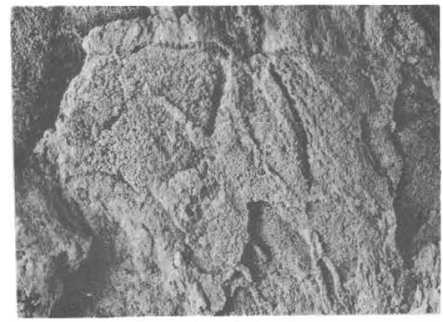

11

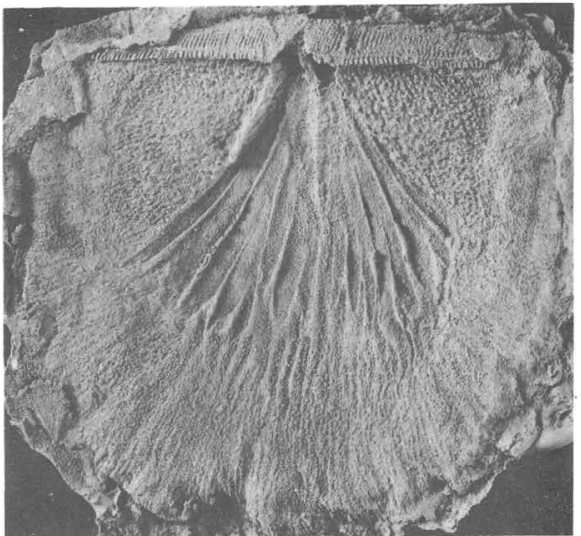

12

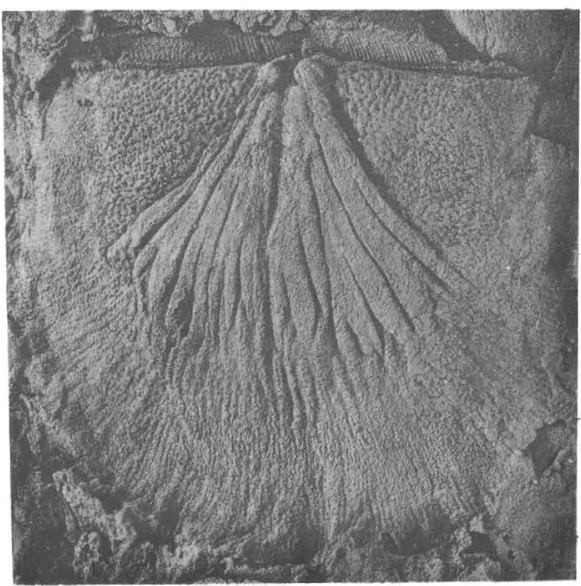

13 


\section{PLATE 8}

Figures 1-8. Protoleptostrophia cf. P. blainvillei (Billings, 1874) (p. 22).

Tomhegan Formation. Brassua Lake quadrangle, Somerset County, Maine.

1. Latex replica of exterior of pedicle valve $(X 2)$. USNM 126154A. USGS loc. 2820-SD.

2, 3. Latex replica and impression of interior of brachial valve ( $\times 2$ ). USNM 126140. USGS loc. 2750-SD.

4. Impression of exterior of brachial valve $(x 1)$. USNM 126137B. USGS loc. 2820-SD.

5, 6. Impression and latex replica of interior of brachial valve ( $\times 1$ ). USNM 126137A. USGS 2820-SD.

7, 8. Latex replica of exterior and impression of interior of pedicle valve $(\times 1)$. USNM 126136B, A. USGS loc. 2820-SD.

9-13. Protoleptostrophia sp. (p. 23).

Lower sandstone of Tarratine Formation. Somerset County, Maine. $(\times 2)$.

9, 10. Impression of interior and latex replica of exterior of pedicle valve. USNM 126135B, A. USGS loc. 2719-SD, Long Pond quadrangle.

11. Impression of interior of brachial valve. USNM 126134A. USGS loc. 2719-SD, Long Pond quadrangle.

12, 13. Latex replicas of interior of brachial valve. USNM 126133, 126132. USGS loc. 2701-SD, Brassua Lake quadrangle.

14-18. Strophonella cf. S. punctulifera (Conrad, 1838) (p. 23).

Parker Bog Formation. USGS loc. 3477-SD, Pierce Pond quadrangle, Somerset County, Maine. $\times 1$.

14. Latex replica of exterior of pedicle valve from slab. USNM 126119.

15. Latex replica of exterior of pedicle valve from slab. USNM 126119.

16, 17. Latex replica and impression of interior of pedicle valve. USNM 126143.

18. Latex replica of interior of brachial valve, USNM 126157A. 
GEOLOGICAL SURVEY

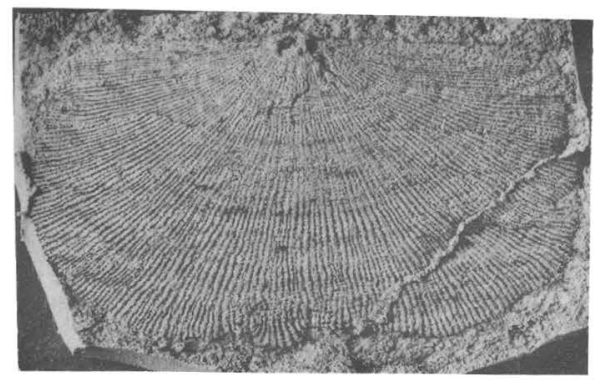

1

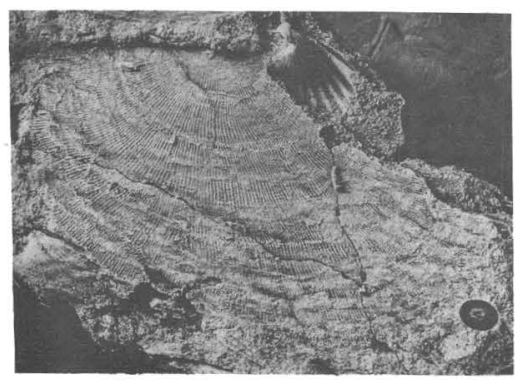

4

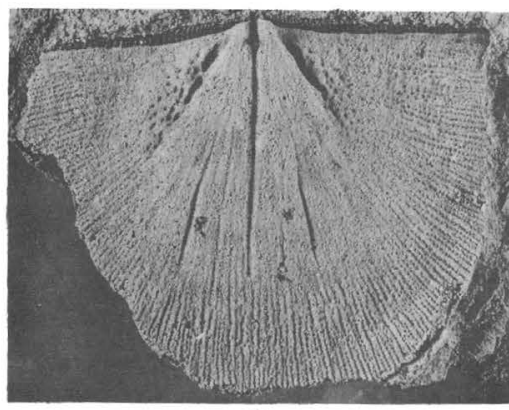

9

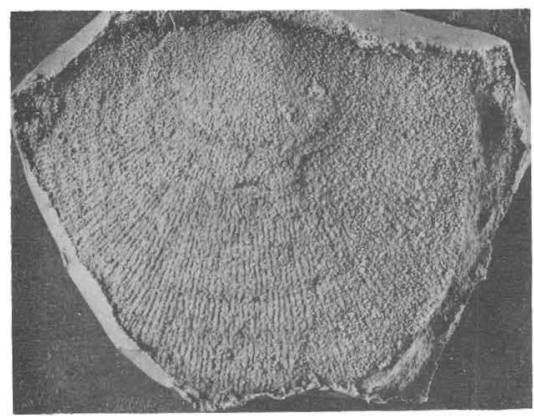

10

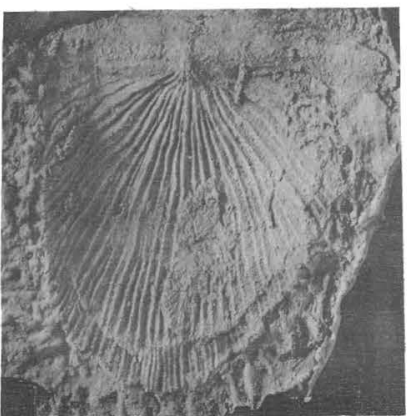

14

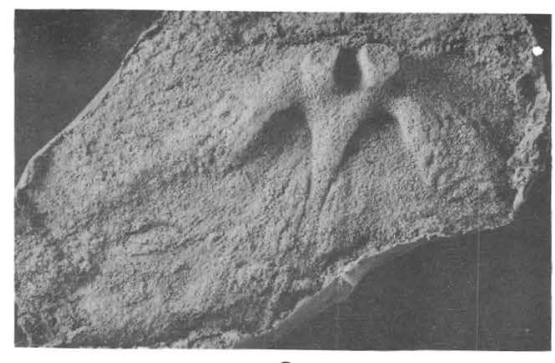

2
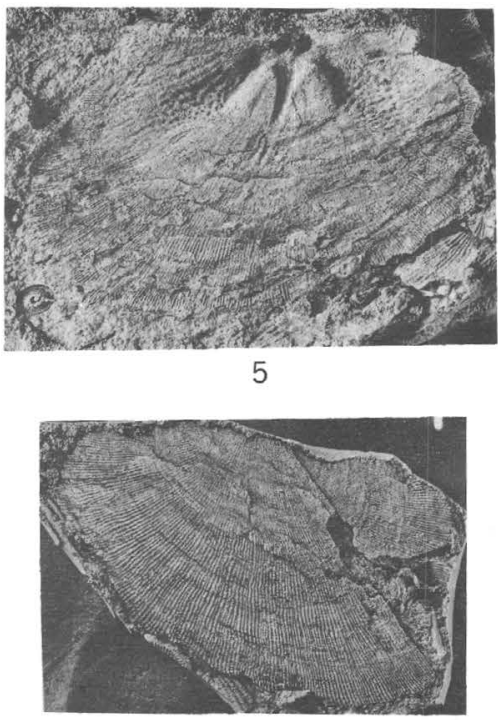

7

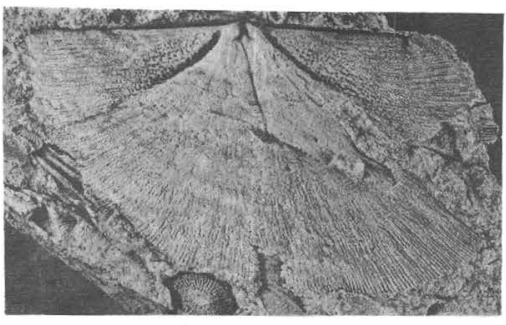

8

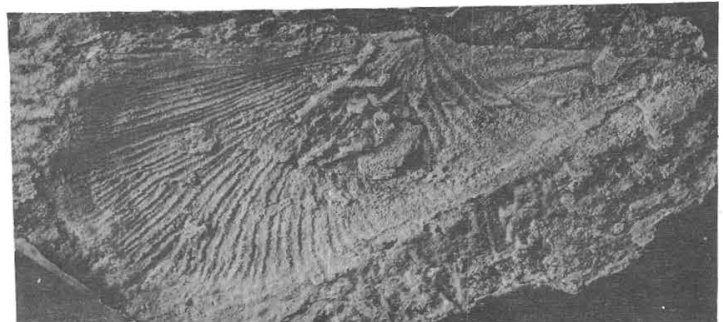

15

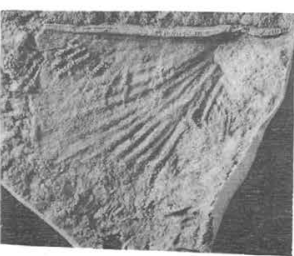

16

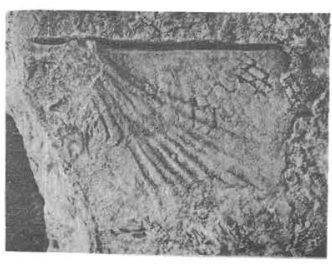

17
PROFESSIONAL PAPER 784 PLATE 8

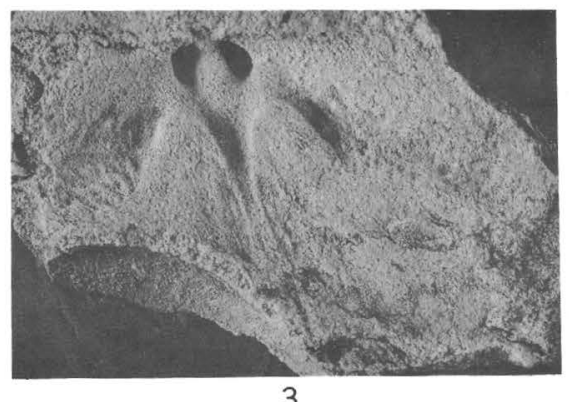

3
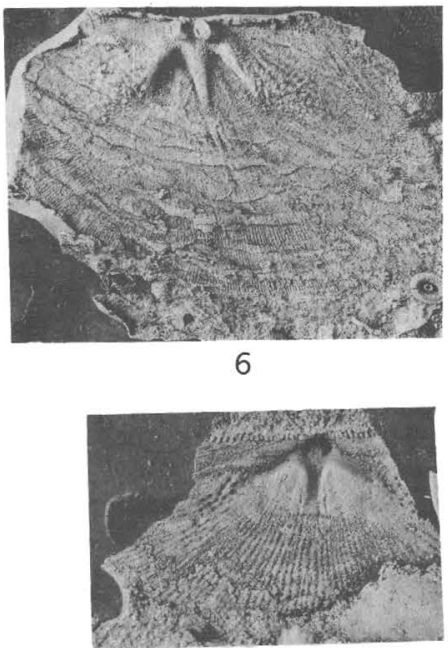

11

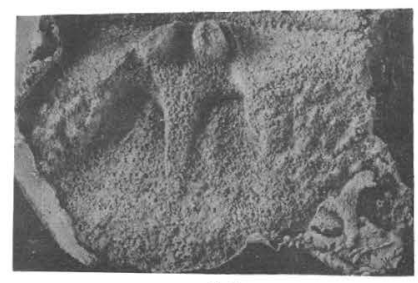

12

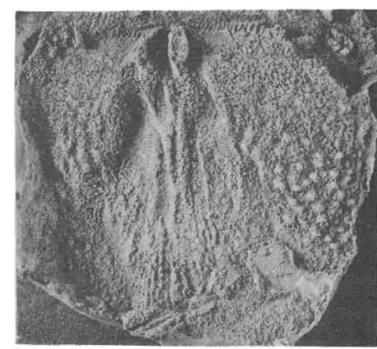

13

PROTOLEPTOSTROPHIA AND STROPHONELLA

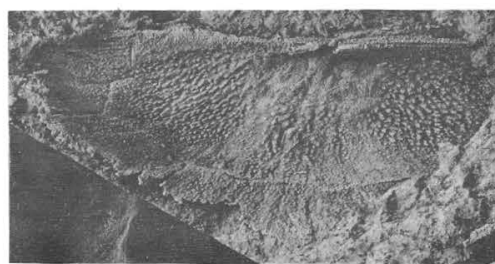

18 


\section{PLATE 9}

FIGURES 1-11. "Schuchertella" becraftensis (Clarke, 1900) (p. 24).

1-6. Lower sandstone of Tarratine Formation. Long Pond quadrangle, Somerset County, Maine.

1, 3. Impression and latex replica of interior of brachial valve $(\times 3)$. USNM 126138. USGS loc. 2719-SD.

2, 4. Impression and latex replica of brachial valve $(\times 3)$. USNM 126151B, A. USGS loc. 2777-SD.

5. Latex replica of interior of brachial valve $(\times 2)$. USNM $126160 \mathrm{~B}$. USGS loc. 2719-SD.

6. Latex replica of exterior of pedicle valve (posterior view $\times 4$ ). USNM 126162A. USGS loc. 2719-SD.

7. Impression of exterior of brachial valve $(\times 1)$. USGS 126139B. Seboomook Formation. USGS loc. 2761-SD, Brassua Lake quadrangle, Somerset County, Maine.

8, 11. Impression and latex replica of interior of pedicle valve $(\times 1)$. USNM 126156B. Seboomook Formation. USGS 3091-SD, Long Pond quadrangle, Somerset County, Maine.

9, 10. Impression and latex replica of interior of pedicle valve $(\times 3)$. USNM 126124. Lower sandstone of Tarratine Formation. USGS loc. 2720-SD, Long Pond quadrangle, Somerset County, Maine.

12-14. "Schuchertella" sp." (p. 24).

Tomhegan Formation. USGS loc. 2820-SD, Brassua Lake quadrangle, Somerset County, Maine.

12. Latex replica of interior of brachial valve (posterior view $\times 2$ ). USNM 126148A.

13, 14. Latex replicas of interior and exterior of brachial valve $(\times 1)$. USNM 126148A, B.

15-17. Hipparionyx sp. (p. 24).

McKenney Ponds member of Tarratine Formation. USGS loc. 2810-SD, Pierce Pond quadrangle, Somerset County, Maine. $\times 1$.

15. Impression of interior of pedicle valve. USNM $126149 \mathrm{~A}$.

16. Interior of pedicle valve. USNM $126149 \mathrm{~B}$.

17. Impression of interior of brachial valve. USNM $126150 \mathrm{C}$.

18-20. Leptaenisca sp. (p. 25).

Beck Pond Limestone. USGS loc. 3499-SD, Spencer Lake quadrangle, Somerset County, Maine. $\times 2$.

18. Exterior of pedicle valve (posterior view). USNM 126129.

19, 20. Partly exfoliated pedicle valves. USNM 126129, 126128B.

21-37. Cyrtoniscus nectus (Clarke, 1907) (p. 25).

Tomhegan Formation. USGS loc. 2852-SD, Brassua Lake quadrangle, Somerset County, Maine.

21. Latex replica of interior of pedicle valve $(X 3)$. Specimen misplaced.

22. Impression of interior of pedicle valve $(X 4)$. USNM 127392B.

23,24 . Latex replicas of exterior and intr of brachial valve $(\times 4)$. USNM 126223B, A.

25,26 . Impression of interior and latex replica of exterior of pedicle valve $(\times 4)$. USNM 126229 .

27, 35. Impressions of exterior and interior of brachial valve $(\times 4)$. USNM 126223B, A.

28. Impression of exterior of brachial valve $(\times 3)$. USNM 126248

29, 30. Impressions of interior and exterior of brachial valve (× 4). USNM 126228.

31. Latex replica of interior of pedicle valve $(\times 3)$. USNM 126247.

32-34. Latex replicas of interior of brachial valve $(\times 4)$. USNM 126227, 126222, 126223A.

36. Latex replica of exterior of pedicle valve $(\times 4)$. USNM 126231A.

37. Impression of interior of pedicle valve $(\times 4)$. USNM 127391A. 
GEOLOGICAL SURVEY
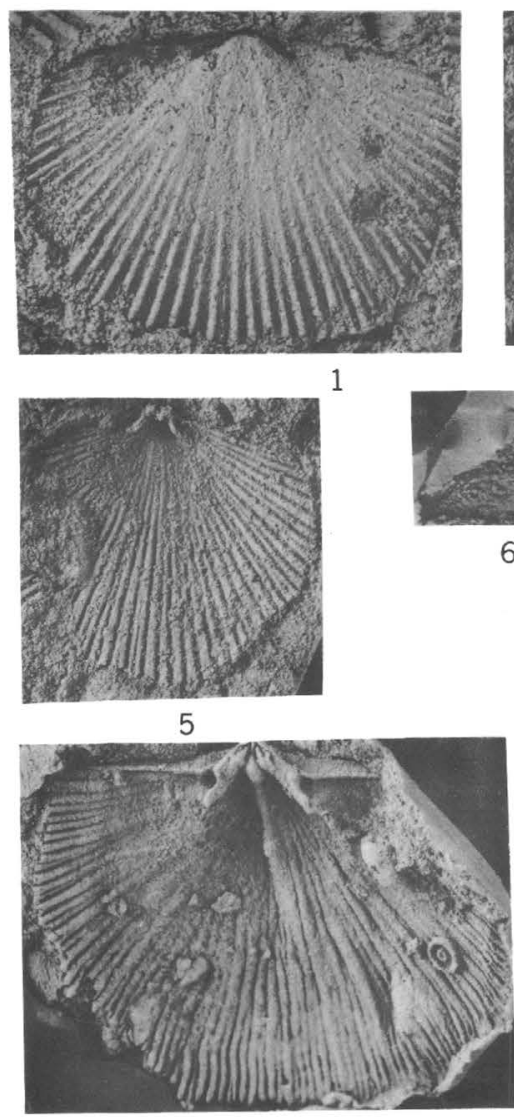

12
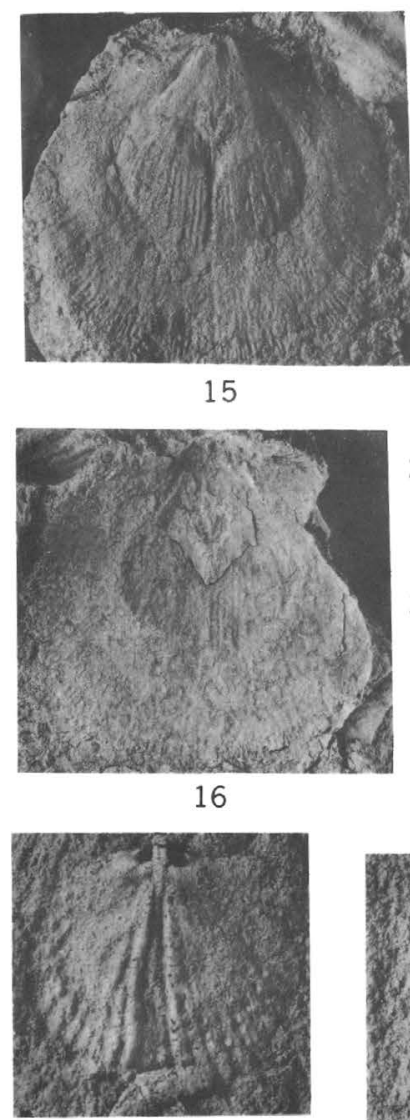

33

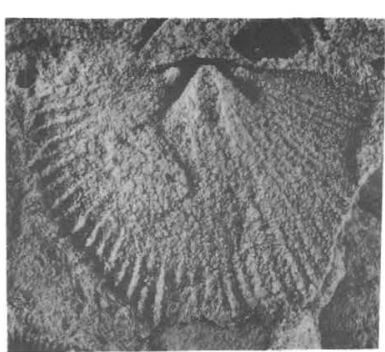

2

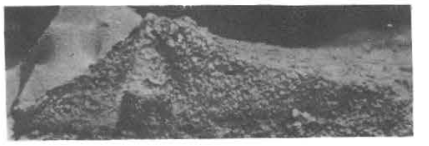

6
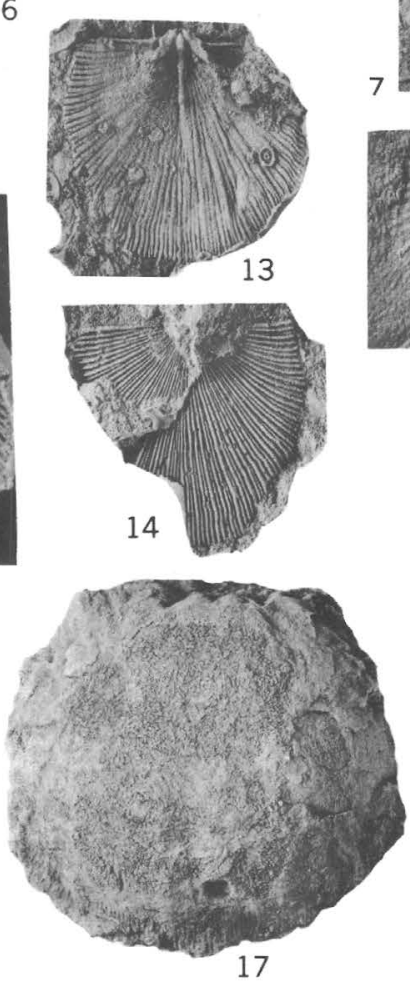

23 fon
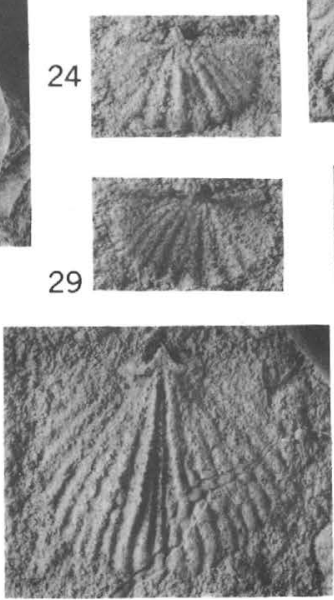

34
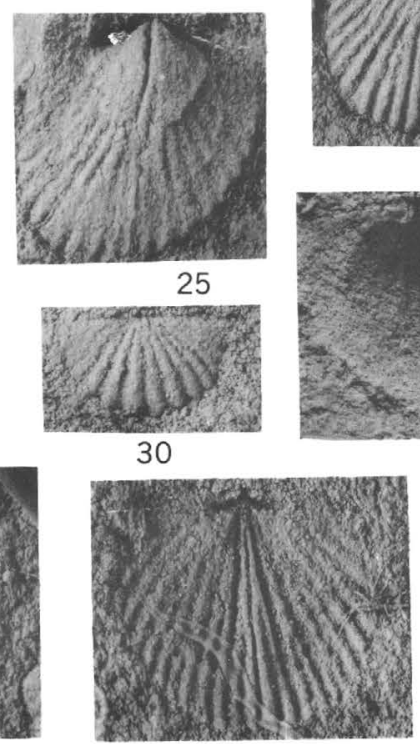

35

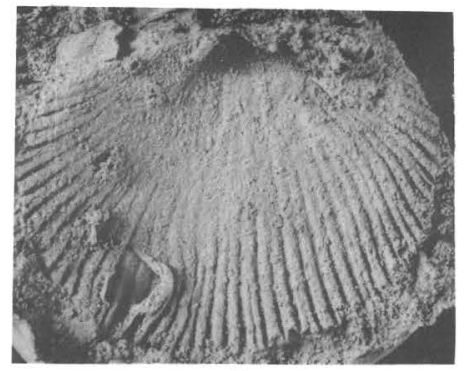

3
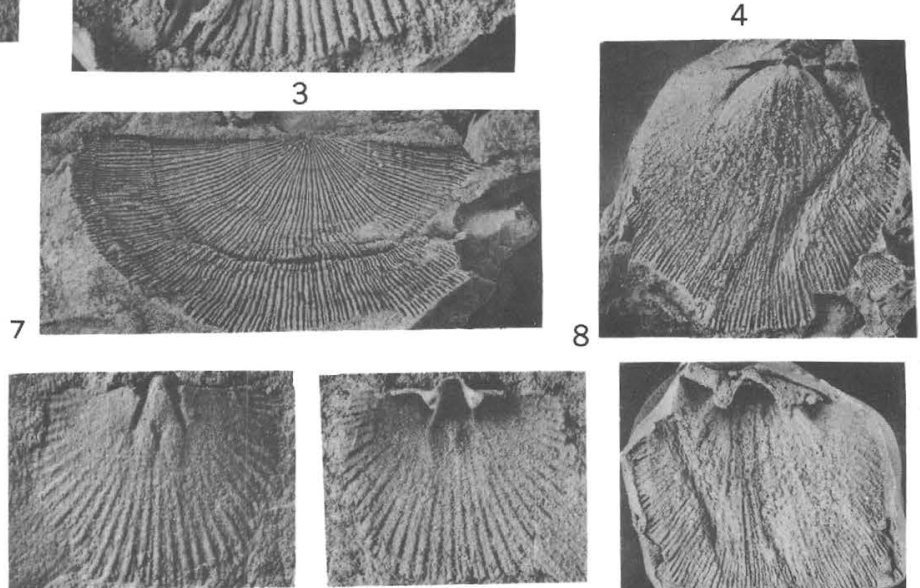

9
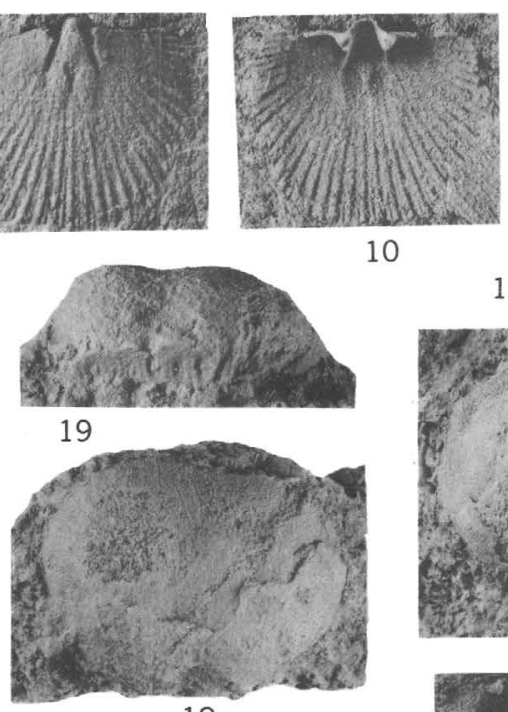

10

11
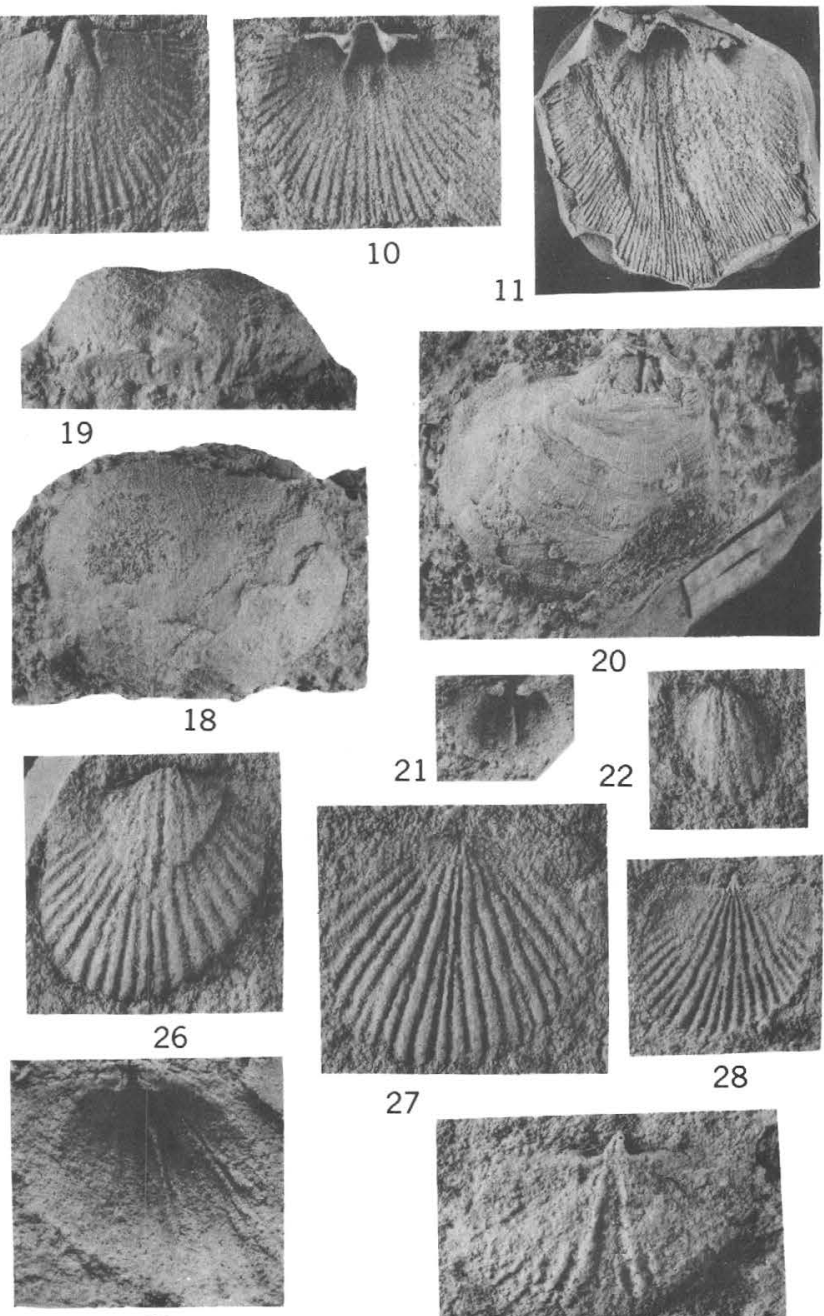

31

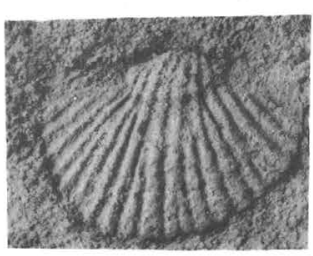

36

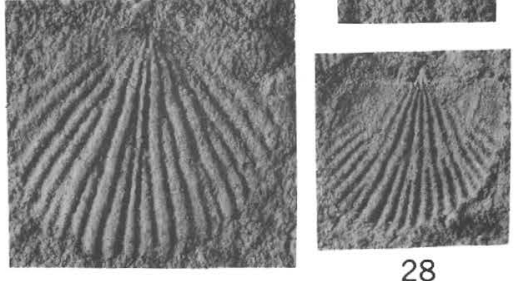

27
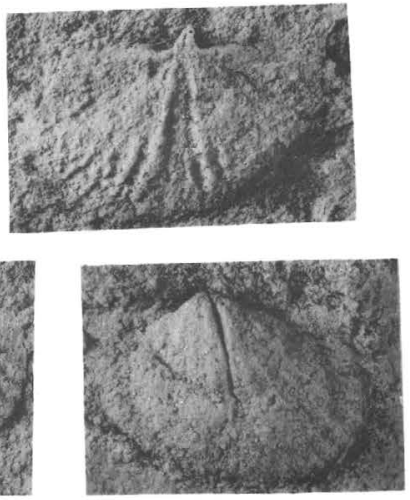

37

“SCHUCHERTELLA", HIPPARIONYX, LEPTAENISCA, AND CYRTONISCUS 


\section{PLATE 10}

FIGURES 1-7. Eccentricosta sp. (p. 25).

Hardwood Mountain Formation. Attean quadrangle, Somerset County, Maine.

1. Impression of exterior of brachial valve (X 2). USNM 160121. USGS loc. 5583-SD.

2. Impression of exterior of pedicle valve $(X 3)$. Note impression of spines and undulating costellae. USNM 160122A. USGS loc. 5995-SD.

3. Impression of interior of pedicle valve $(X 3)$. Note the short myophragm at the posterior of the valve. USNM 160122B. USGS loc. 5995-SD.

4. Impression of exterior of pedicle valve $(\times 2)$. Note impression of spines and undulating costellae. USNM 160123. USGS loc. 4841-SD.

5. Impression of exterior of pedicle valve $(\times 2)$. Note undulating costellae. USNM 160124. USGS loc. 5583-SD.

6. Impression of interior of pedicle valve $(\times 3)$. USNM 160125. USGS loc. 4841-SD.

7. Impression of exterior of pedicle valve $(\times 2)$. Note impressions of spine bases and undulating costellae. USNM 160126. USGS loc. 4841-SD.

8-12. Dawsonelloides canadensis (Billings, 1874) (p 26).

Lower sandstone of Tarratine Formation, Somerset County, Maine.

8. Impression of interior of pedicle valve $(X 1)$. USNM 126244. USGS loc. 2813-SD, Pierce Pond quadrangle.

9. Impression of interior of brachial valve $(\times 2)$. USNM 126246 . USGS loc. 2813-SD, Pierce Pond quadrangle.

10. Impression of interior of pedicle valve $(\times 1)$. USNM 126233. USGS loc. 2701-SD, Brassua Lake quadrangle.

11. Impression of interior of pedicle valve $(\times 1)$. USNM $126251 \mathrm{~B}$. USGS loc. 2701-SD, Brassua Lake quadrangle.

12. Latex replica of exterior of brachial valve (posterior view $\times$ 2). USNM 126252. USGS loc. 2701-SD, Brassua Lake quadrangle. 
GEOLOGICAL SURVEY

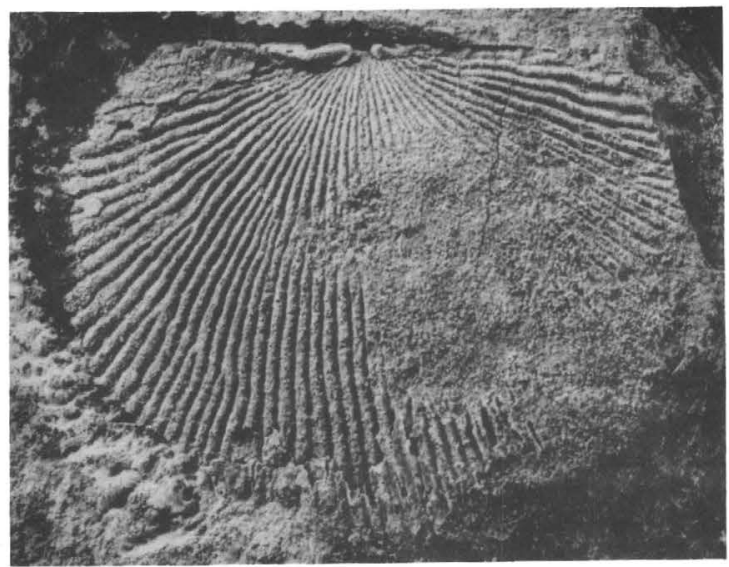

1

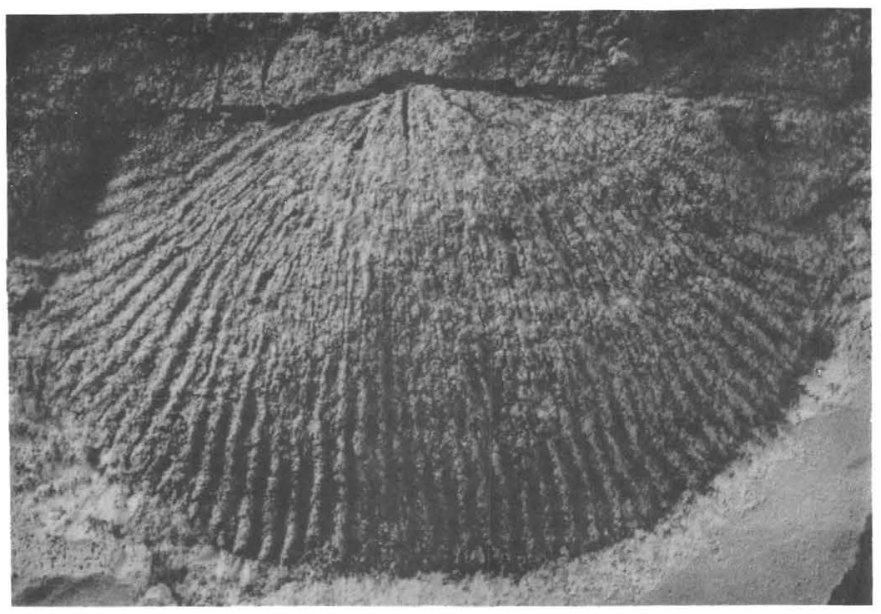

3

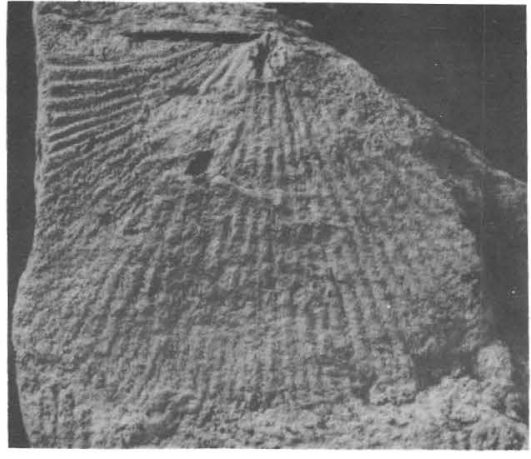

6

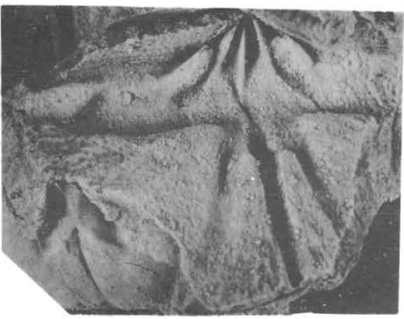

PROFESSIONAL PAPER 784 PLATE 10

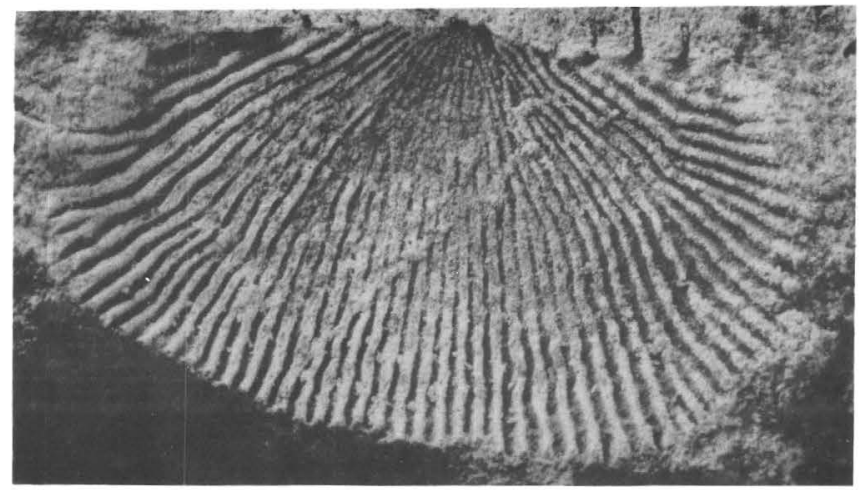

2
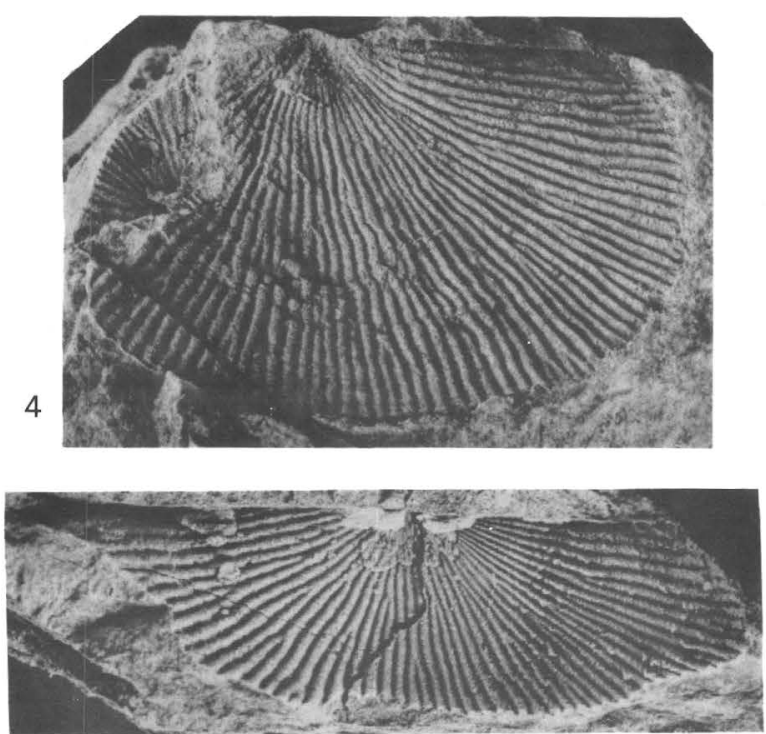

5
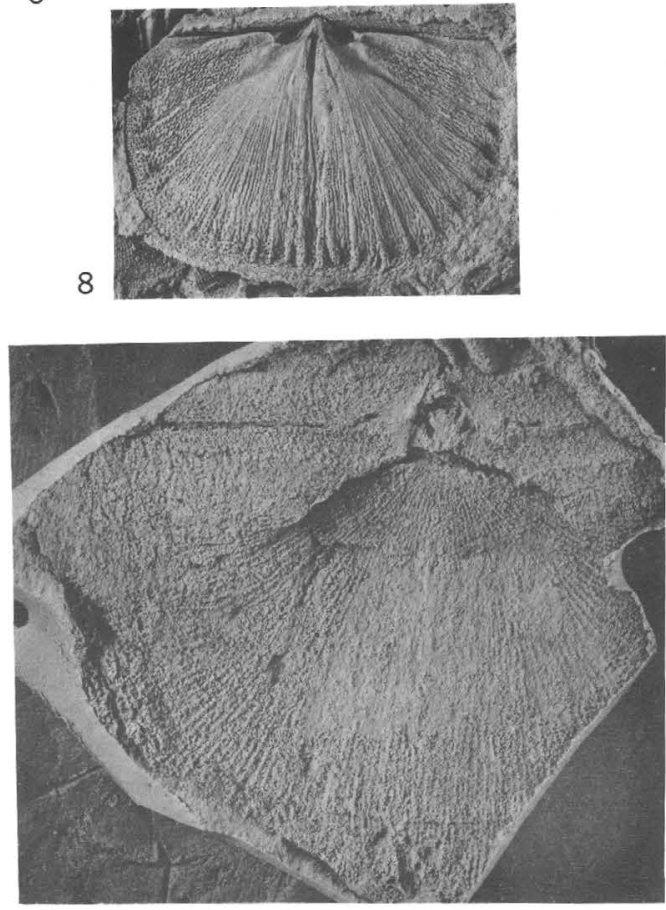

12 


\section{PLATE 11}

FIgURE 1-7. Dawsonelloides canadensis (Billings, 1874) (p. 26).

Lower sandstone of Tarratine Formation. Somerset County, Maine.

1, 2. Latex replicas of interior of pedicle and brachial valves $(\times 1)$. USNM 126250, 126245. USGS loc. 2701-SD, Brassua Lake quadrangle.

3 , 4. Latex replicas of interior of pedicle valve $(\times 1, \times 4)$. USNM 126233, 126253B. USGS loc. 2813-SD, Brassua Lake quadrangle.

5. Latex replica of interior of brachial valve $(X 1)$. USNM 126239A, USGS loc 2701-SD, Brassua Lake quadrangle.

6. Latex replica of exterior of pedicle valve $(x 1)$. USNM 126253C. USGS loc. 2813-SD, Pierce Pond quadrangle.

7. Impression of interior of pedicle valve $(\times 1)$. USNM 126250. USGS loc. 2701-SD, Brassua Lake quadrangle.

8-16. Eodevonaria arcuata (Hall, 1857) (p. 27).

Tomhegan Formation. USGS loc. 2820-SD, Brassua Lake quadrangle, Somerset County, Maine.

8, 9. Impressions of interior of pedicle valve $(X 2)$. USNM $126235 \mathrm{~A}, 126230 \mathrm{~A}$.

10. Latex replica of exterior of pedicle valve $(X 2)$. USNM 126230B.

11, 14. Latex replica and impression of interior of brachial valve $(\times 2)$. USNM 126238A.

12, 16. Impression and latex replica of exterior of brachial valve $(\times 2, \times 4)$. USNM $126234 \mathrm{~B}, \mathrm{~A}$.

13. Impression of interior of pedicle valve $(X 2)$. USNM $126232 \mathrm{~A}$.

15. Impression of exterior of brachial valve $(X 2)$. USNM $126226 \mathrm{~A}$.

17-25. Chonostrophiella complanata (Hall, 1857) (p. 28).

Lower sandstone of Tarratine Formation. USGS loc. 2718-SD, Long Pond quadrangle, Somerset County, Maine.

17, 23. Impression and latex replica of interior of brachial valve ( $X$ 2). USNM 126236A.

18. Impression of interior of pedicle valve $(X 2)$. USNM $126254 \mathrm{~B}$.

19. Impression of interior of brachial valve $(X 2)$. USNM 126241.

20. Impression of interior of brachial valve $(\times 1)$. USNM $126237 \mathrm{C}$.

21, 22. Impression and latex replica of interior of pedicle valve ( $X$ 1). USNM 126225.

24,25 . Latex replicas of interior and exterior of pedicle valve ( $X$ 2). USNM 126240, 126243. 


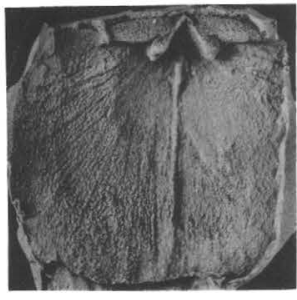

1

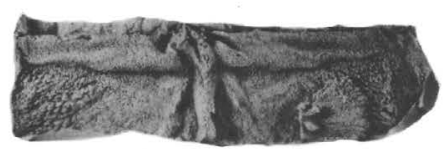

5

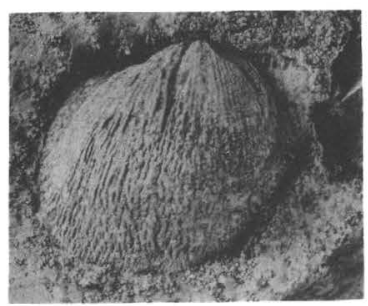

9

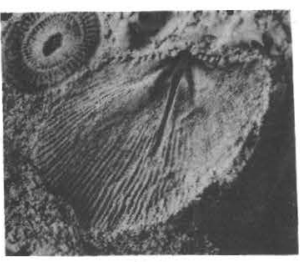

14

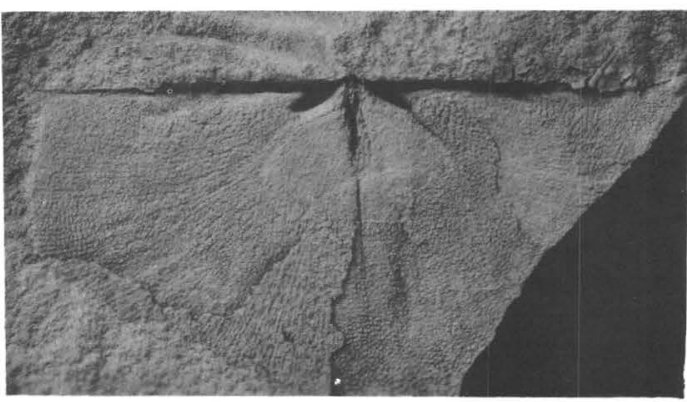

18

21

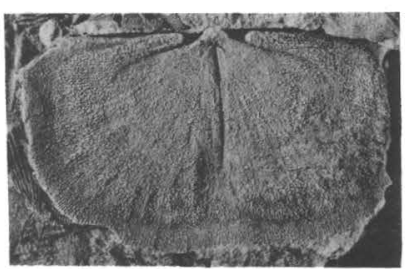

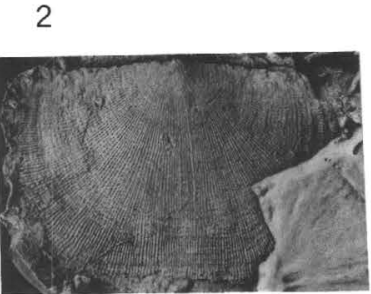

6

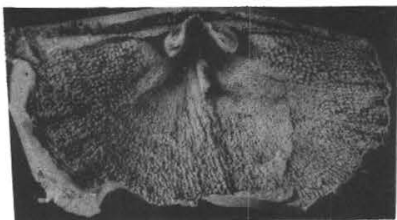

3

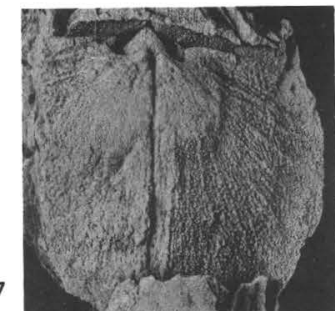

8

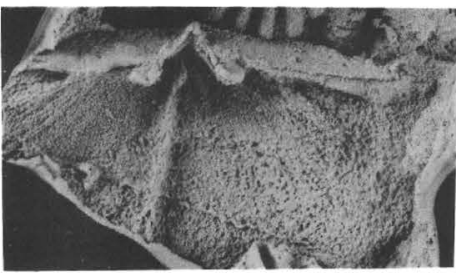

4
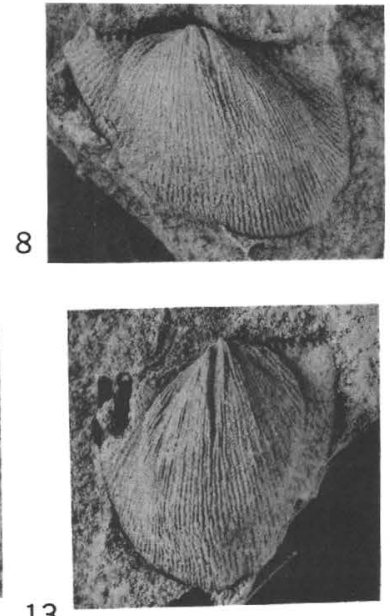

13

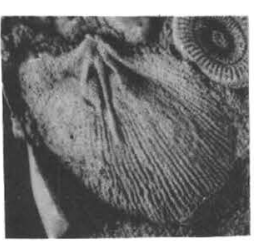

11

12
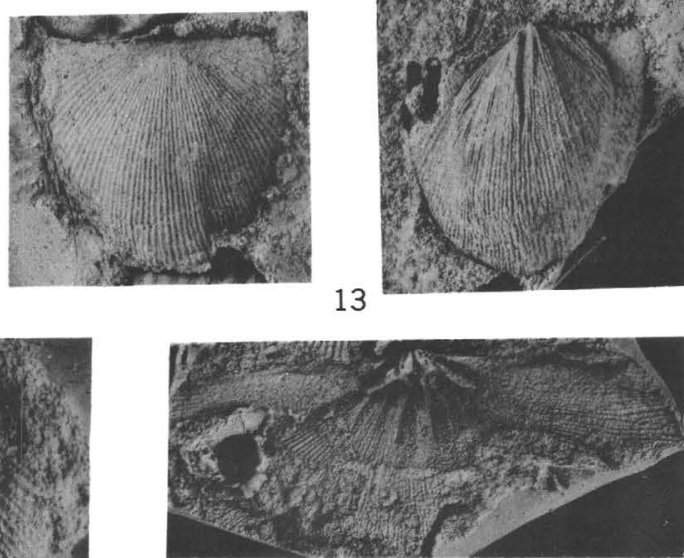

17
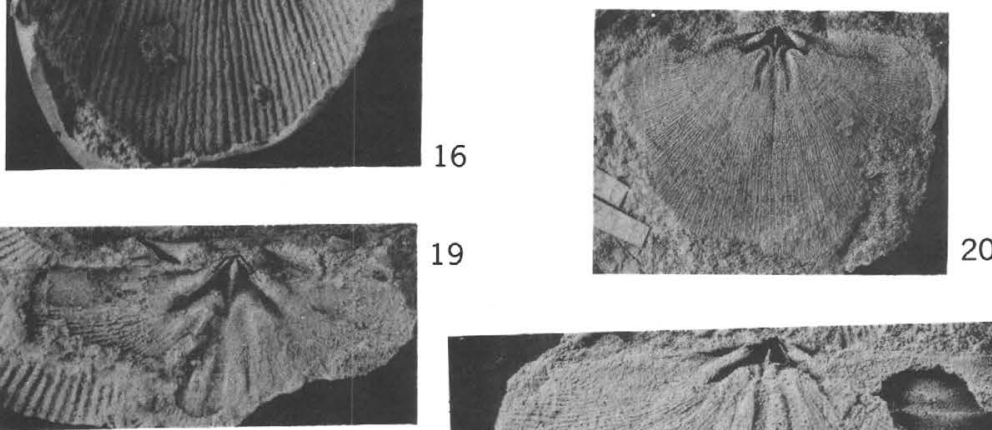

16

19

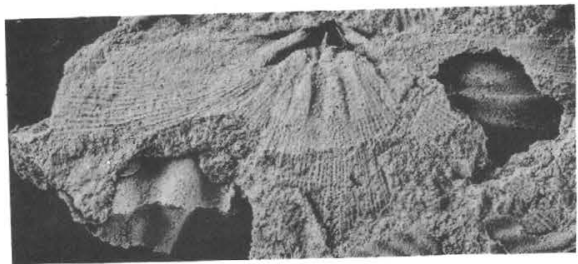

25

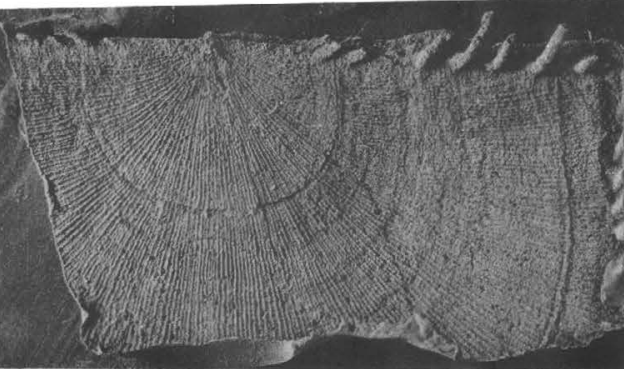




\section{PLATE 12}

Figures 1, 2. Chonostrophiella complanata (Hall, 1857) (p. 28).

Latex replica of interior $(X 2)$ and exterior $(X 1)$ of pedicle valve. USNM 126242A, B. Lower sandstone of Tarratine Formation. USGS loc. 2718-SD, Long Pond quadrangle, Somerset County, Maine.

3-11. Cupularostrum macrocosta Boucot, n. sp. (p. 29).

Tomhegan Formation, Brassua Lake quadrangle, Somerset County, Maine.

3. Latex replica of exterior of pedicle valve $(\times 1)$. USNM 125856. USGS loc. 2750-SD.

4. Impression of the interior of pedicle valve $(\times 1)$. USNM 125857. USGS loc. 2842-SD.

5. Impression of interior of brachial valve (posterior view $\times 3$ ). USNM 125855A. USGS loc. 2750-SD.

6 , 7. Impressions of interior of brachial valve $(\times 3, \times 1)$. USNM 125904B. USGS loc. 2750-SD.

8, 10. Impression (posterior view $\times 3$ ) and latex replica $(\times 2)$ of exterior of brachial valve. USNM 125852. USGS loc. 2842-SD.

9. Impression of interior of pedicle valve $(\times 1)$. Holotype, USNM 125851A. USGS loc. 2750-SD.

11. Latex replica of interior of pedicle valve $(X 1)$. USNM 125852A. USGS loc. 2842-SD.

12-21. Cupularostrum? sp. (p. 30).

Beck Pond Limestone. USGS loc. 3601-SD, Spencer Lake quadrangle, Somerset County, Maine. $\times 3$.

12, 13, 16, 19, 21 . Exterior: brachial valve, pedicle valve, posterior, side, and anterior views. USNM 125859.

14, 15, 17, 18, 20. Exterior: side, anterior, pedicle valve, brachial valve, and anterior views. USNM 125862

22-26. Ancillotoechia sp. (p. 30).

Exterior: side, posterior, anterior, and brachial valve views $(X$ $3)$; pedicle valve $(X 4)$. USNM 125902. Beck Pond Limestone. USGS loc. 3499-SD, Spencer Lake quadrangle, Somerset County, Maine.

27-31. "Ancillotoechia" cf. A. altisulcata (Amsden, 1951) (p. 31).

Exterior: posterior, anterior, side, brachial valve, and pedicle valve views $(\times 2)$. USNM 125854. Hardwood Mountain Formation. USGS loc. 3488-SD, Spencer Lake quadrangle, Somerset, County, Maine.

32-36. Sphaerirhynchia sp. 1 (p. 31).

Exterior: side, pedicle valve, brachial valve, posterior, and anterior views $(\times 2)$. USNM 125874. Hardwood Mountain Formation. USGS loc. 3470-SD, Spencer Lake quadrangle, Somerset, County, Maine. 
GEOLOGICAL SURVEY

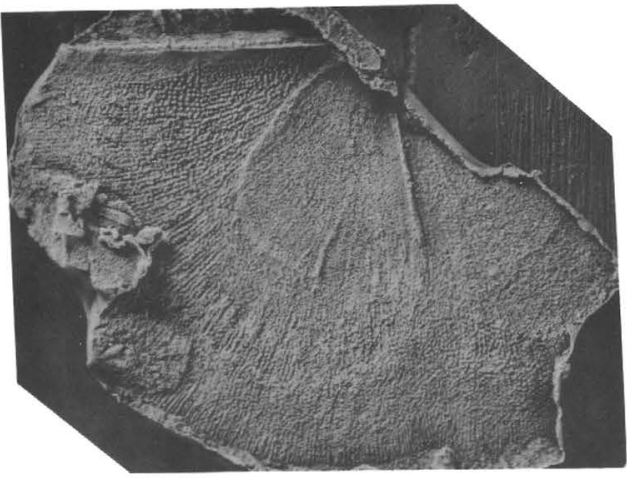

1

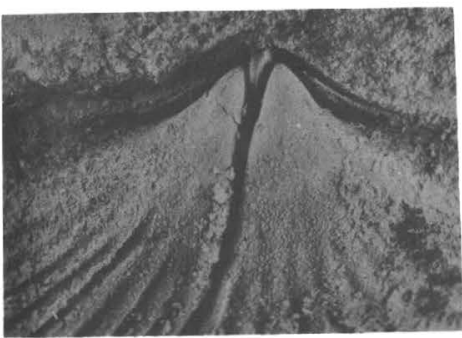

6

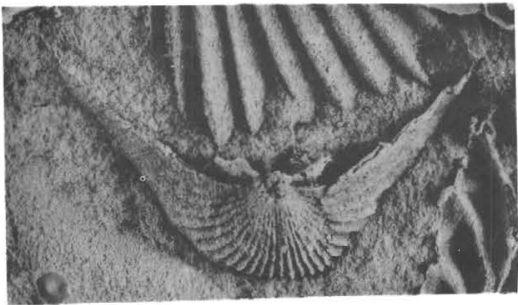

10

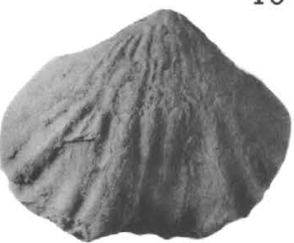

17

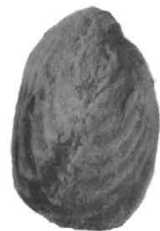

21

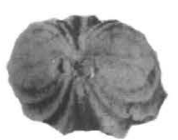

23

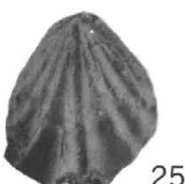

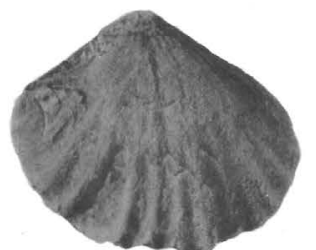

18

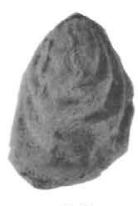

22

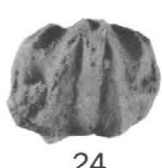

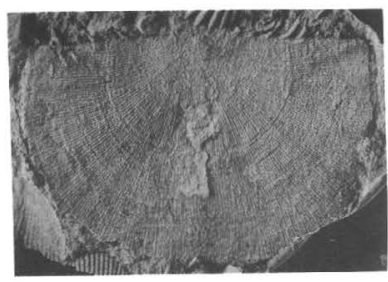

2

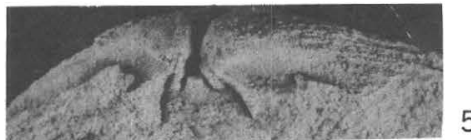

3
PROFESSIONAL PAPER 784 PLATE 12
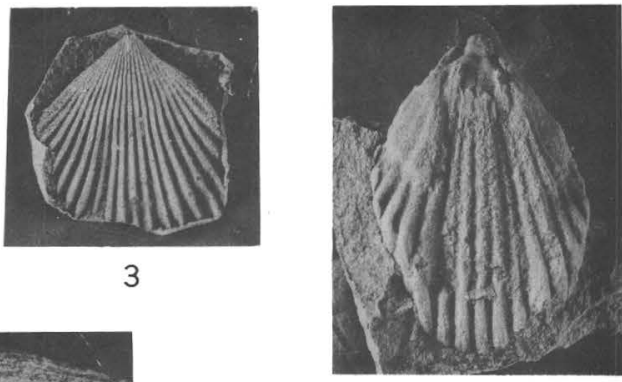

4

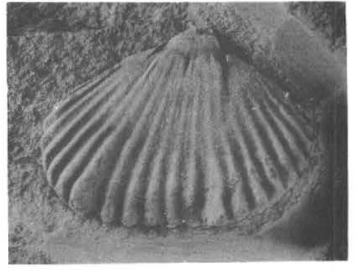

9

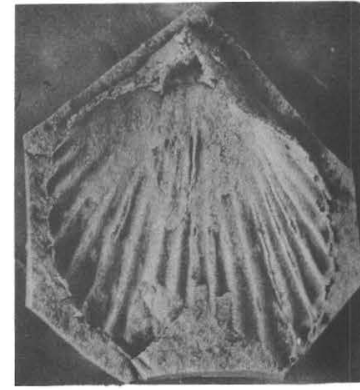

11

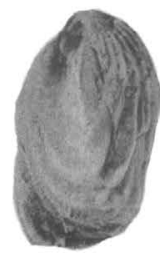

14

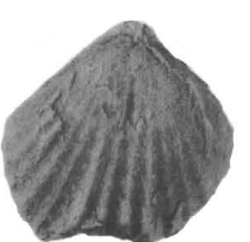

12

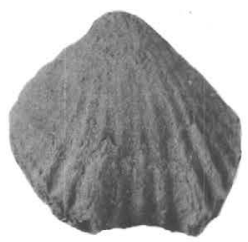

13

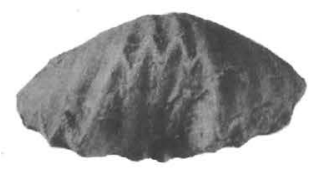

15

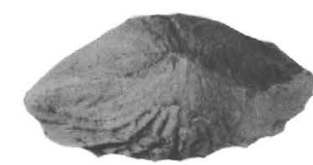

19

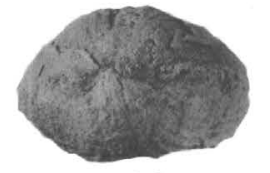

16

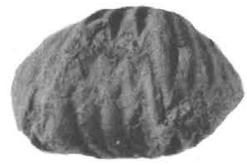

20

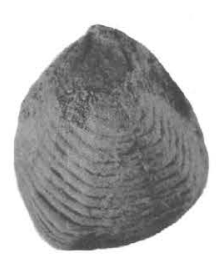

32

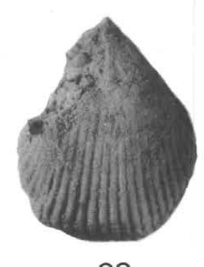

33
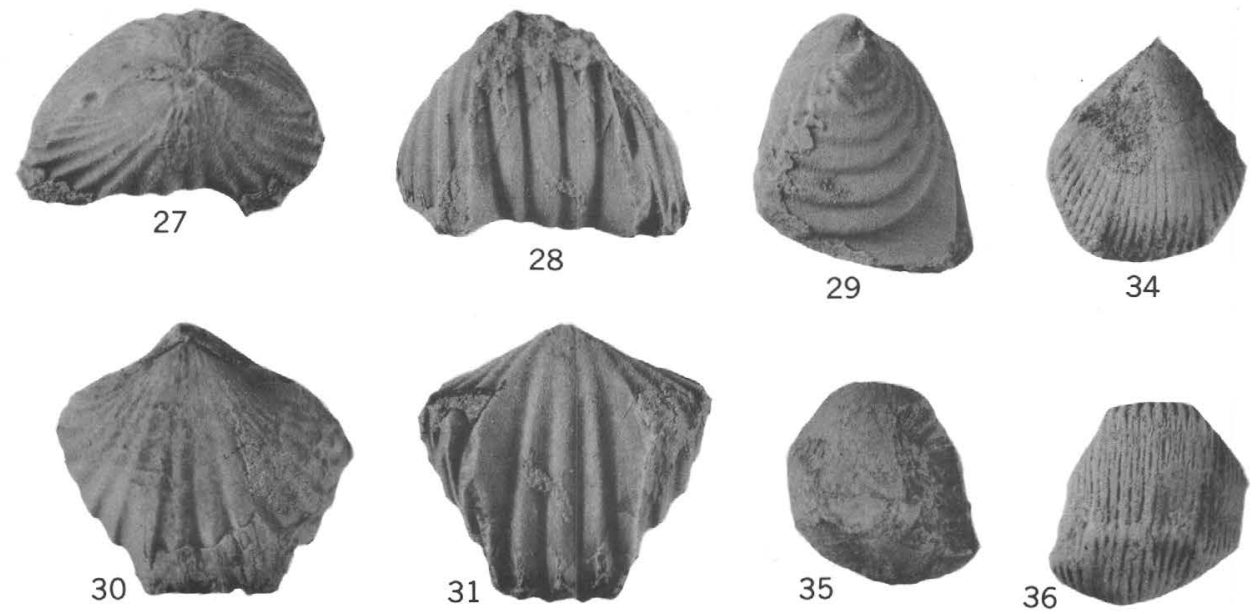

CHONOSTROPHIELLA, CUPULAROSTRUM, CUPULAROSTRUM?, ANCILLOTOECHIA " ANCILLOTOECHIA", AND SPHAERIRHYNCHIA 


\section{PLATE 13}

FIGURES 1-6. Sphaerirhynchia sp. 2 (p. 32).

Beck Pond Limestone. USGS loc. 3499-SD, Spencer Lake quadrangle, Somerset County, Maine.

1, 3-6. Exterior: pedicle valve, posterior, brachial valve, anterior, and side views $(\times 3)$. USNM 125876.

2. Impression of interior of brachial valve $(\times 1)$. USNM 125877.

7-12. Sphaerirhynchia sp. 3 (p. 33).

Beck Pond Limestone. USGS loc. 3601-SD, Spencer Lake quadrangle, Somerset County, Maine. $\times 1$.

7. Impression of interior of pedicle valve. USNM 125871.

8-12. Exterior: brachial valve, pedicle valve, posterior, anterior, and side views. USNM 125870.

13-18. Sphaerirhynchia? sp. (p. 33).

Hardwood Mountain Formation. USGS loc. 3488-SD, Spencer Lake quadrangle, Somerset, County, Maine.

13-15. Impression of interior of pedicle valve, brachial valve, and posterior view $(\times 2)$. USNM 127385A.

16, 17. Exterior: side and anterior views $(\times 2)$. USNM 127385A.

18. Section of brachial and pedicle valves $(X 5)$. USNM $127385 \mathrm{~B}$.

19-25. Sulcatina sp. (p. 33).

Hardwood Mountain Formation. USGS loc. 3488-SD, Spencer Lake quadrangle, Somerset County, Maine. $\times 1$.

19. Latex replica of exterior (posterior view). USNM 125853A.

20, 25. Partly exfoliated exterior (side and posterior views). USNM 125847B.

21. Exterior of brachial valve. USNM 125848.

22. Impression of interior (anterior view). USNM 125847A.

23,24 . Impression of interior of pedicle and brachial valves. USNM 125850.

26-28. Sphaerirhynchia sp. 1 (p. 31).

Hardwood Mountain Formation. USGS loc. 5586-SD, Attean quadrangle, Somerset County, Maine. $\times 2$.

26, 27. Impressions of interior (posterior view). USNM 160127, 160128.

28. Impression of interior of pedicle valve. Note raised impressions for adductor atttachment surrounded by diductor field. USNM 160129. 
GEOLOGICAL SURVEY

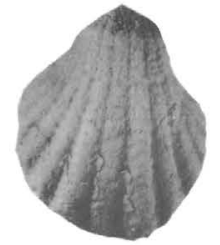

1

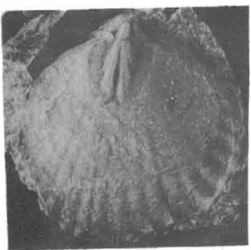

7

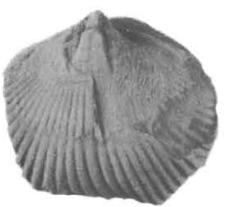

13

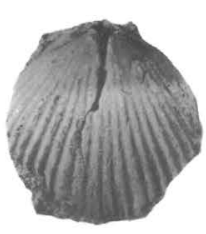

2

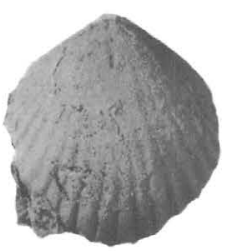

8

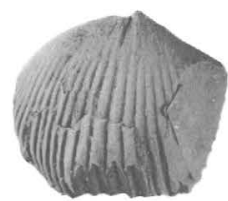

14

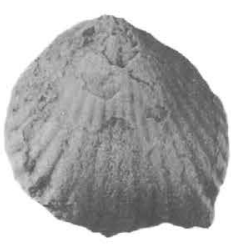

9

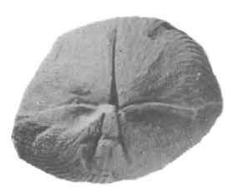

1.5

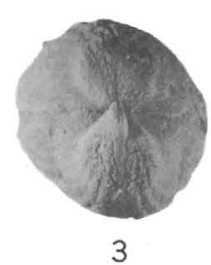

PROFESSIONAL PAPER 784 PLATE 13

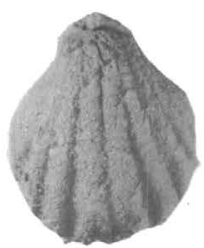

4

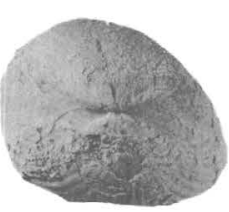

10

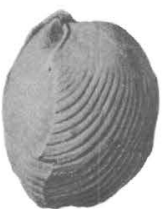

16

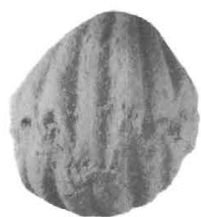

5

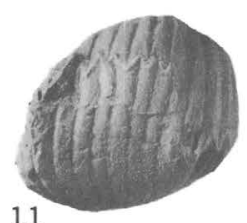

11

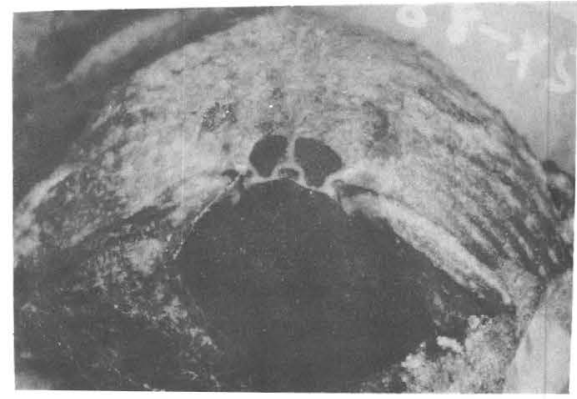

18

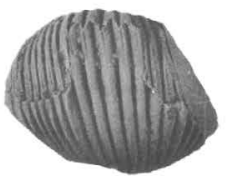

17

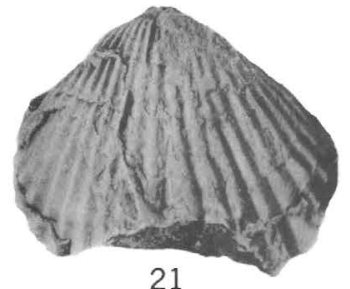

20

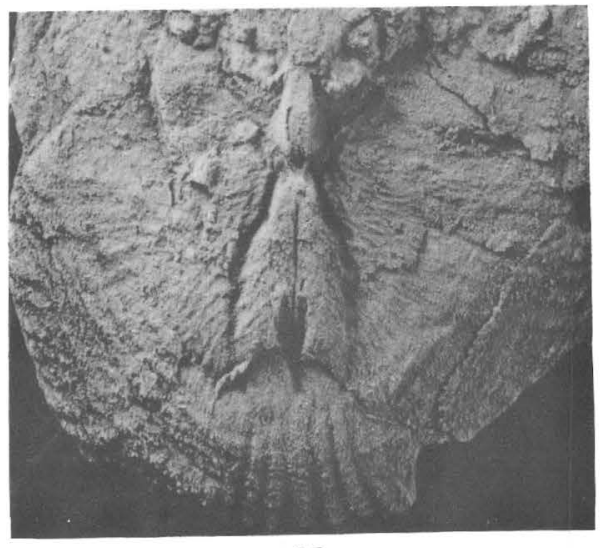

28

23

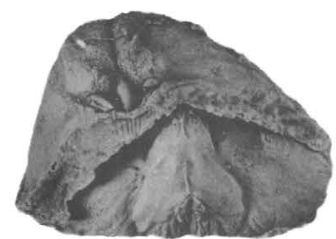

24

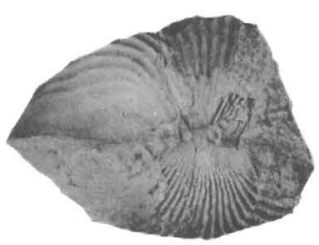

25

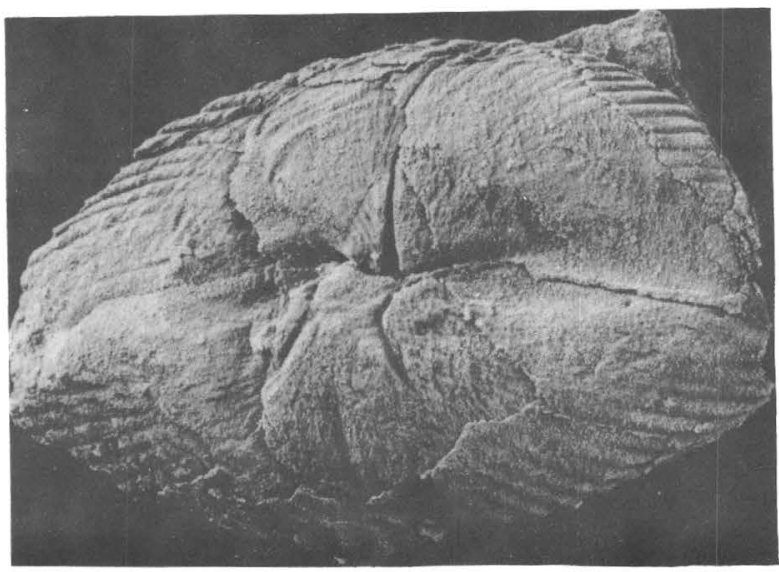

26
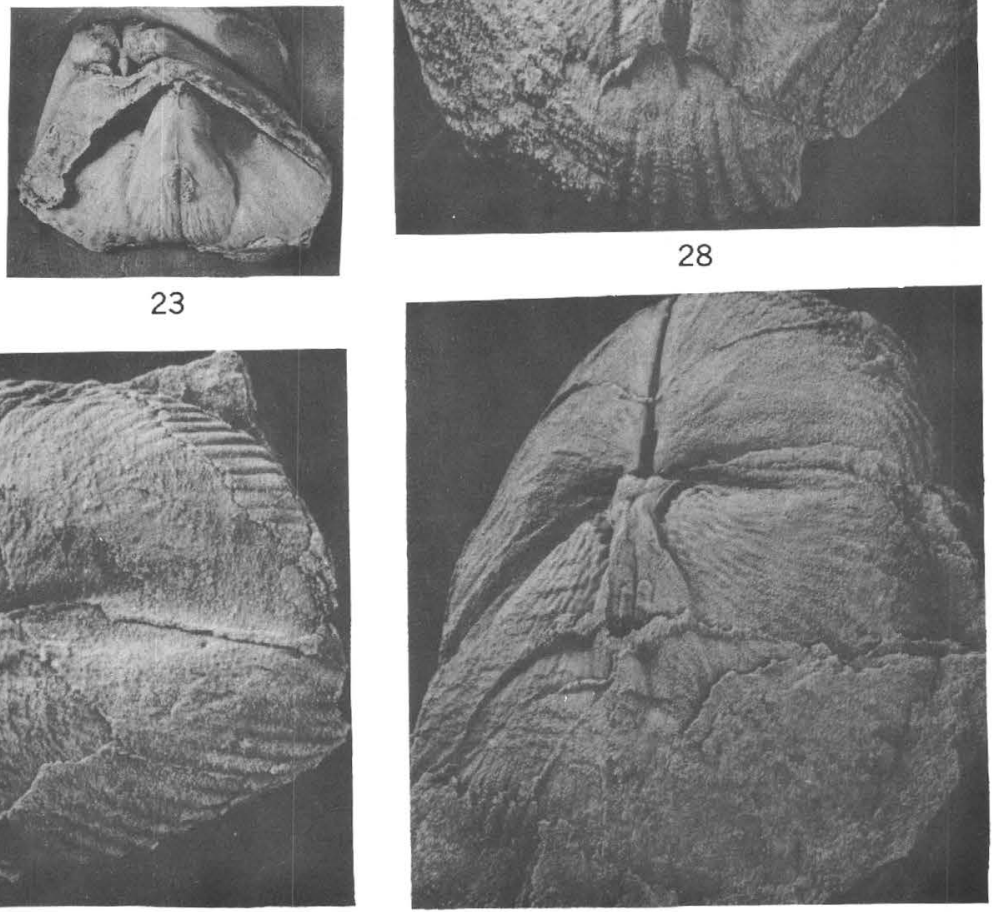

27
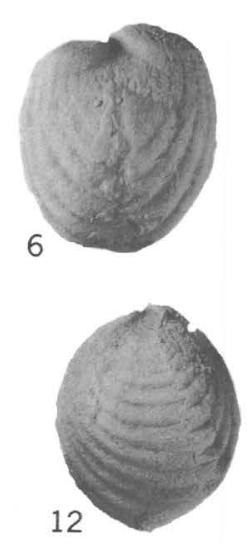

12 


\section{PLATE 14}

Figures 1-5. Costellirostra sp. (p. 34).

Exterior: brachial valve, pedicle valve, posterior, anterior, and side views $(\times 3)$. USNM 125885. McKenney Ponds Member of Tarratine Formation. USGS loc. 2806-SD, Pierce Pond quadrangle, Somerset County, Maine.

6-13. Eatonia ef E. medialis (Vanuxem, 1842) (p. 34).

Beck Pond Limestone. USGS loc. 3499-SD, Spencer Lake quadrangle, Somerset County, Maine.

6, 8-11. Exterior: side $(\times 2)$, brachial valve $(X 1)$, anterior $(X$ $2)$, posterior $(X 2)$, and pedicle valve $(X 2)$ views. USNM 125882B.

7, 12. Impressions of interior of pedicle $(X 1)$ and brachial $(X$ 3) valves. USNM 125873.

13. Impression of interior of brachial valve $(x 1)$. USNM 125872.

14-21. Machaeraria mainensis Boucot, n. sp. (p. 35).

Base of Hobbstown Formation. USGS loc. 3479-SD, Spencer Lake quadrangle, Somerset County, Maine.

14, 15. Impression and latex replica of interior of pedicle valve $(\times 2)$. USNM $125867 \mathrm{~A}$.

16. Latex replica of exterior of pedicle valve $(\times 2)$. USNM $125867 \mathrm{~A}$.

17, 19. Impression $(\times 3)$ and latex replica $(\times 4)$ of interior of brachial valve. Holotype, USNM 125869A.

18. Latex replica of interior (posterior view $\times 4$ ). Holotype, USNM 125869A.

20. Latex replica of exterior of pedicle valve $(\times 3)$. USNM 125868.

21. Latex replica of exterior (posterior view $\times 3$ ). USNM 125868.

22-27. Atrypa cf. A. tennesseensis Amsden, 1949 (p. 36).

Base of Hobbstown Formation. USGS loc. 3479-SD, Spencer Lake quadrangle, Somerset, County, Maine.

22, 23. Impressions of exterior of pedicle and brachial valves ( $X$ 2). USNM $126003 \mathrm{~A}, \mathrm{~B}$.

24. Impression of interior of brachial valve $(\times 2)$. USNM $126003 \mathrm{C}$.

25, 27. Latex replica and impression of interior of pedicle valve (X 3). USNM 126002.

26. Latex replica of exterior of pedicle valve $(X 3)$. USNM 126004.

28, 29. Atrypa cf. A. arctostriata Foerste, 1903 (p. 36).

Impressions of exterior and interior of brachial valve $(X 3)$.

USNM 126014A, 126015B. Base of Hobbstown Formation. USGS

loc. 3479-SD, Spencer Lake quadrangle, Somerset County, Maine. 


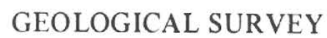
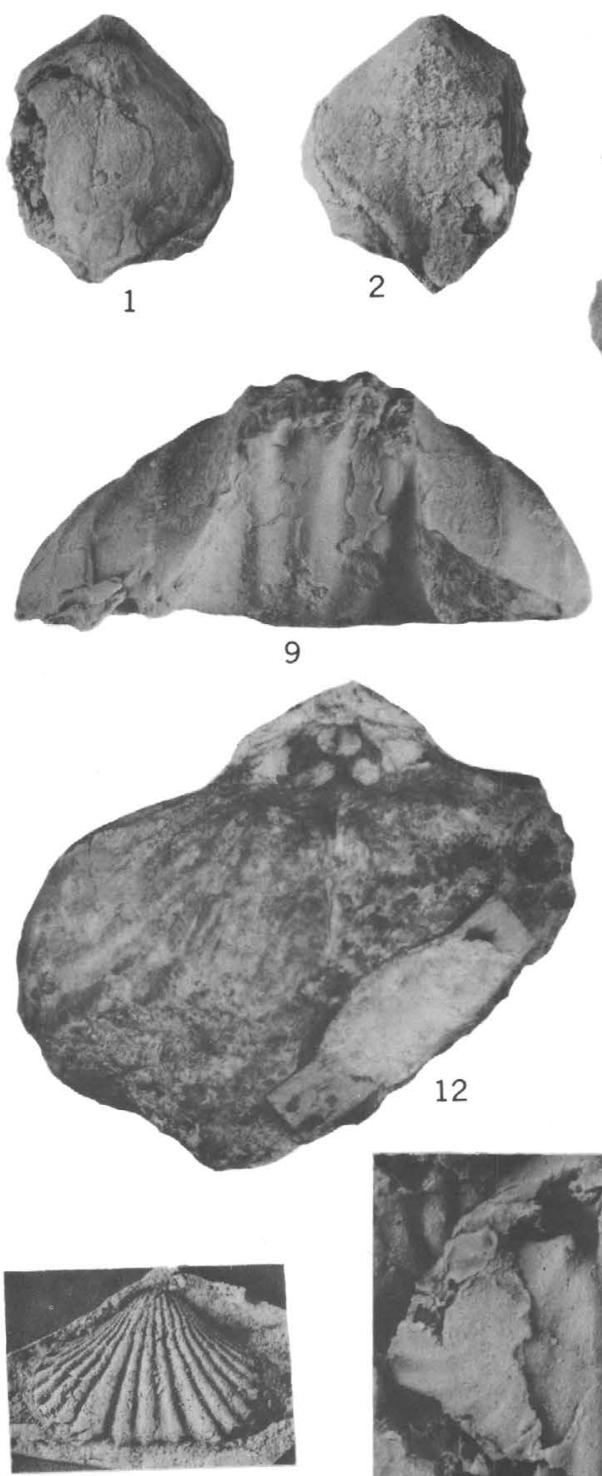

16

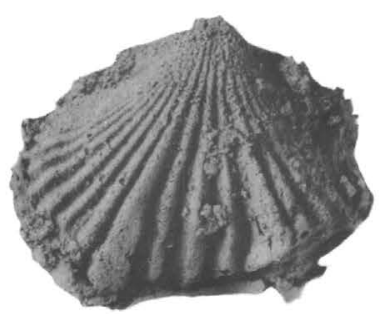

20

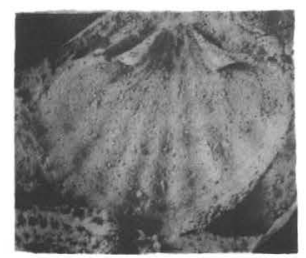

25

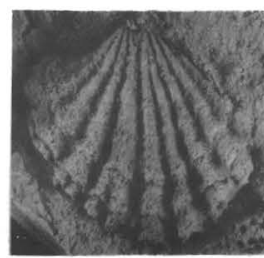

26
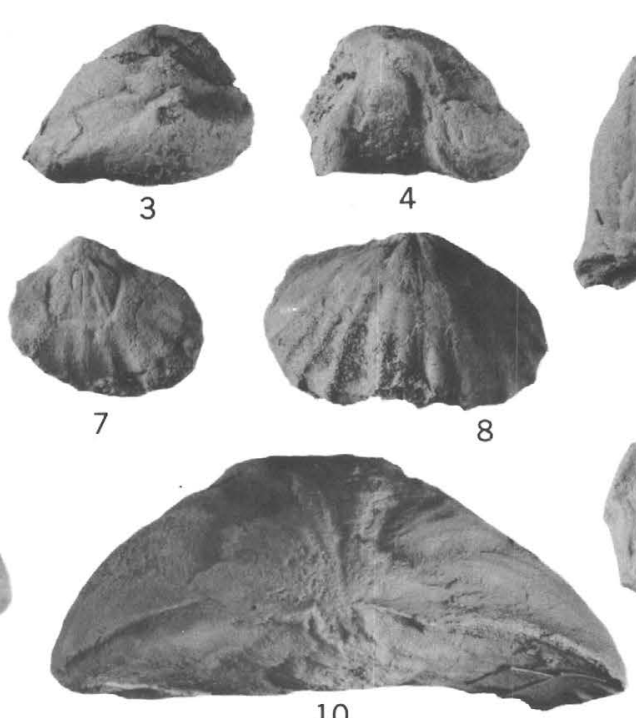

10

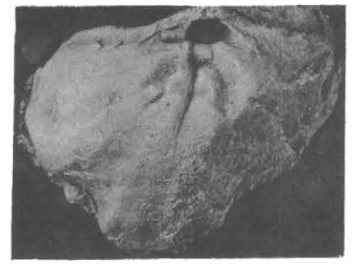

13

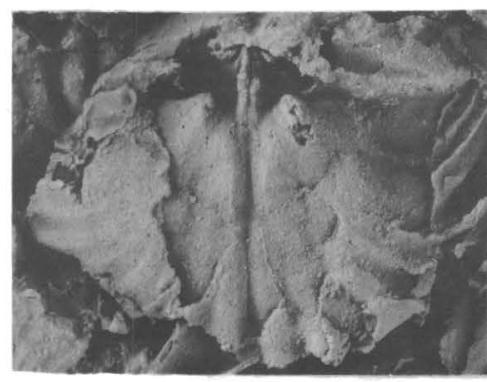

17

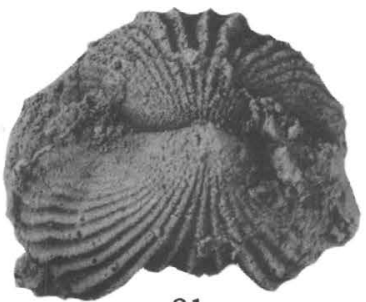

21

18

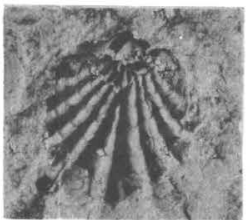

22

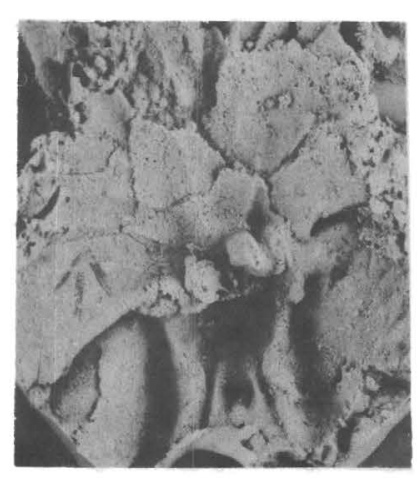

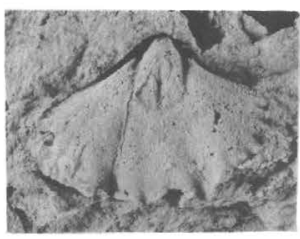

14

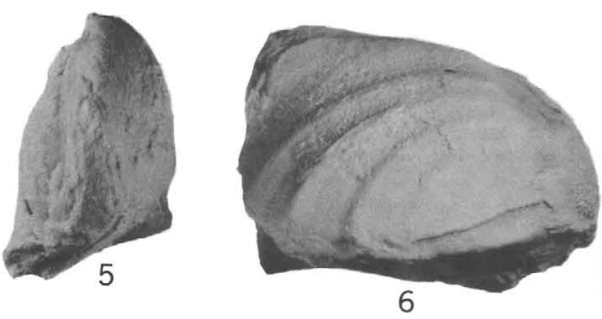

6

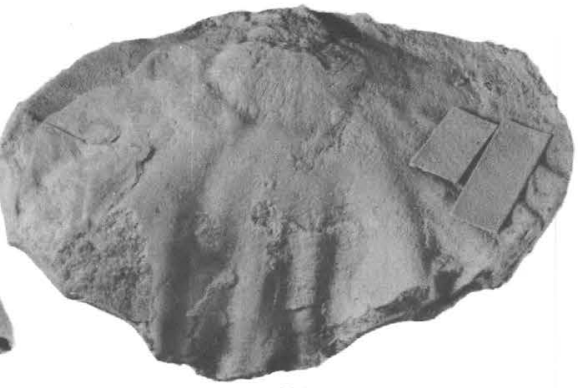

11

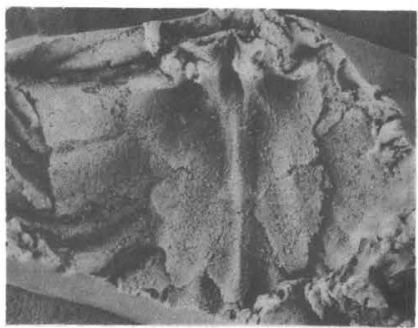

19

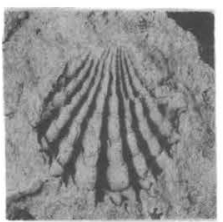

23

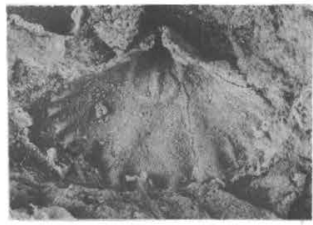

15

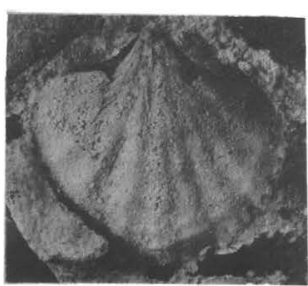

27

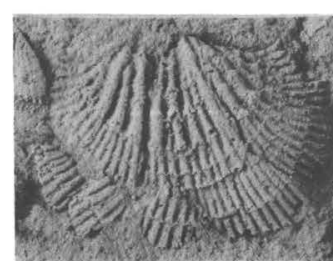

28

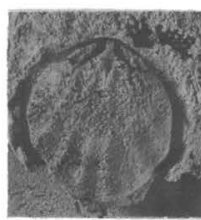

24

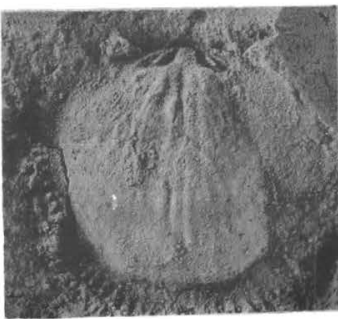

29

COSTELLIROSTRA, EATONIA, MACHAERARIA, AND ATRYPA 


\section{PLATE 15}

Figures 1-6. Atrypa "reticularis" (Linnaeus, 1767) (p. 36).

1-3. Tomhegan Formation. USGS loc. 2750-SD, Brassua Lake quadrangle, Somerset County, Maine. $\times 1$.

1, 3. Impression and latex replica of interior of pedicle valve. USNM 126011.

2. Latex replica of exterior of pedicle valve. USNM 126010A.

4. Exterior of brachial valve $(\times 1)$. USNM 126008A. Hardwood Mountain Formation. USGS loc. 3488-SD, Spencer Lake quadrangle, Somerset County, Maine.

5, 6. Latex replica and impression of interior of brachial valve $(\times 1)$. USNM 126068B. Tomhegan Formation. USGS loc. 2820-SD, Brassua Lake quadrangle, Somerset County, Maine.

7-15. Lissatrypa sp. (p. 37).

7-13. Hardwood Mountain Formation. Spencer Lake quadrangle, Somerset County, Maine.

7, 8. Latex replicas of interior of pedicle $(\times 2)$ and brachial $(\times 3)$ valves. USNM 125908B, A. USGS loc. 3473-SD.

9. Partly exposed spire $(\times 3)$. USNM 126000 . USGS loc. 3488-SD.

10,11 . Impression and latex replica of interior of brachial valve $(\times 3)$. USNM $125905 \mathrm{~B}, \mathrm{~A}$. USGS loc. 3473-SD.

12. Impression of interior of pedicle valve $(\times 2)$. USNM 125908B. USGS loc. 3473-SD.

13. Impression of interior of brachial valve $(\times 3)$. USNM 125905A. USGS loc. 3473-SD.

14, 15. Impressions of interior and exterior of pedicle valve $(\times 3)$. Note the trapezoidal impression of the muscle field (fig. 14) and faint, concentric growth lines (fig. 15). USNM 160130A, B. Hardwood Mountain Formation. USGS loc. 4843-SD, Attean quadrangle, Somerset County, Maine.

16. Nanospira? sp. (p. 37).

Partly exfoliated exterior of brachial valve ( $\times 5$ ). USNM 126108A. Base of Hobbstown Formation.

USGS loc. 3479-SD, Spencer Lake quadrangle, Somerset County, Maine.

17-24. Leptocoelia flabellites (Conrad, 1841) (p. 38).

17-19, 22-24. Lower sandstone of Tarratine Formation. USGS loc. 2718-SD, Long Pond quadrangle, Somerset County, Maine.

17. Impression of interior of brachial valve $(\times 2)$. USNM $126005 \mathrm{~B}$

18, 22. Impression and latex replica of interior of pedicle valve $(\times 2)$. USNM 126001

19. Impression of exterior of pedicle valve $(\times 2)$. USNM $126005 \mathrm{~A}$.

23. Latex replica of interior of brachial valve $(\times 2)$. USNM 127387.

24. Latex replica of exterior of brachial valve $(\times 3)$. USNM 126012.

20. Exterior of brachial valve $(\times 2)$. USNM 126009. Seboomook Formation. USGS loc. 3094-SD, Long Pond quadrangle, Somerset County, Maine.

21. Exterior of brachial valve $(\times 2)$. USNM 125907. Seboomook Formation. USGS loc. 2880-SD, Attean quadrangle, Somerset County, Maine.

25-32. Coelospira sp. (p. 38).

25-28. Hardwood Mountain Formation. USGS loc. 3488-SD, Spencer Lake quadrangle, Somerset County, Maine. $\times 4$.

25, 26. Impressions of interior of pedicle and brachial valves. USNM $126007 \mathrm{C}$.

27. Latex replica of exterior of brachial valve. USNM 126007A.

28. Latex replica of exterior of brachial valve. USNM 126007AA.

29-32. Hardwood Mountain Formation. USGS loc. 5995-SD, Attean quadrangle, Somerset County, Maine. $\times 3$.

29. Impression of interior of pedicle valve. USNM 160131.

30. Impression of interior of pedicle valve (turned to side) USNM 160132A.

31,32 . Impressions of exterior and interior of pedicle valve. USNM 160132B. 160133.

33-35. Hedeina cf. H. macropleura (Conrad, 1840) (p. 39).

33. Partly exfoliated exterior of brachial valve $(\times 1)$. USNM 126076A. Beck Pond Limestone. USGS loc. 3499-SD, Spencer Lake quadrangle, Somerset County, Maine.

34. Exterior of pedicle valve $(\times 1)$. USNM 126006. McKenney Ponds Member of Tarratine Formation. USGS loc. 2806-SD, Pierce Pond quadrangle, Somerset County, Maine.

35. Impression of interior of brachial valve (posterior view $\times 2$ ). USNM 126076A. Beck Pond Limestone. USGS loc. 3499-SD, Spencer Lake quadrangle, Somerset County, Maine. 
GEOLOGICAL SURVEY
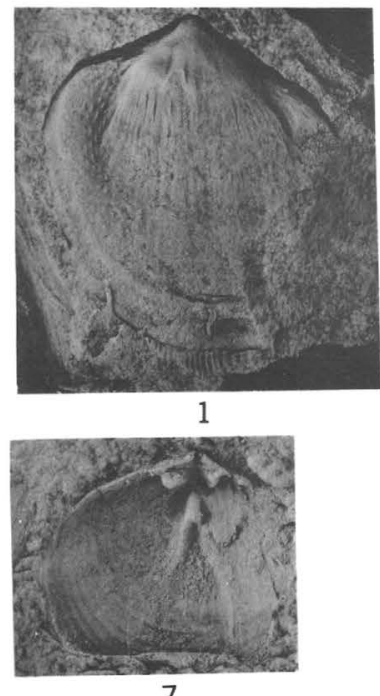

7

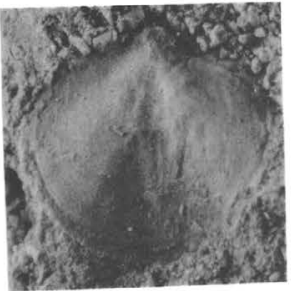

16
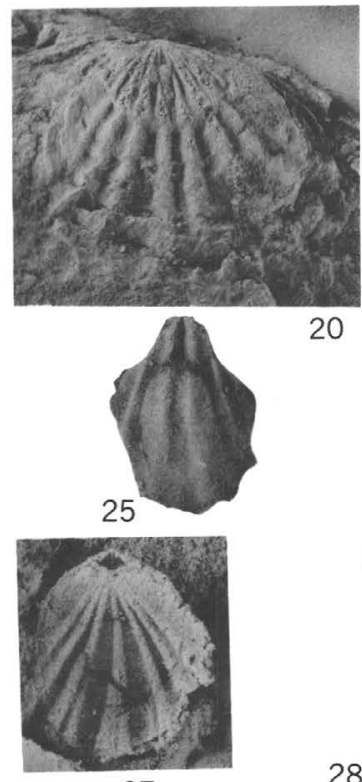

27

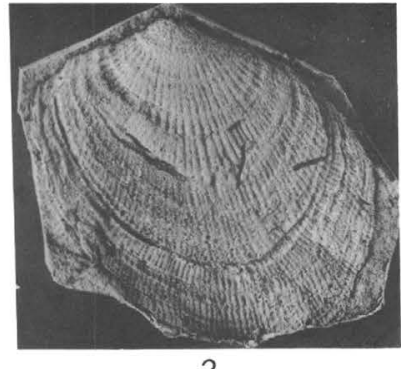

2

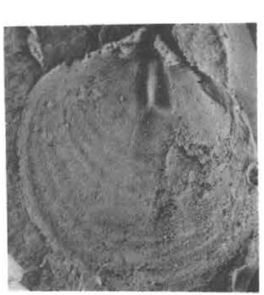

8

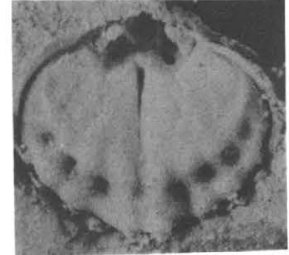

17

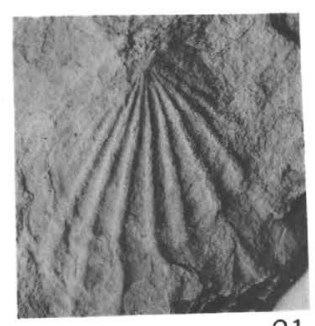

21
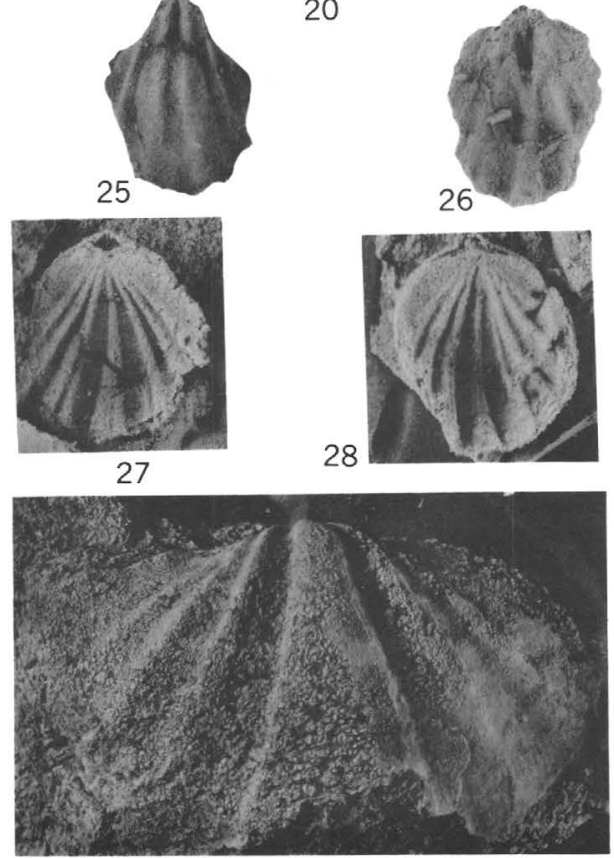

33

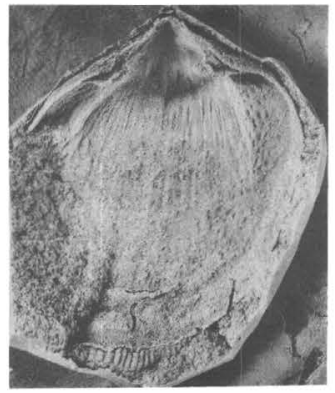

3
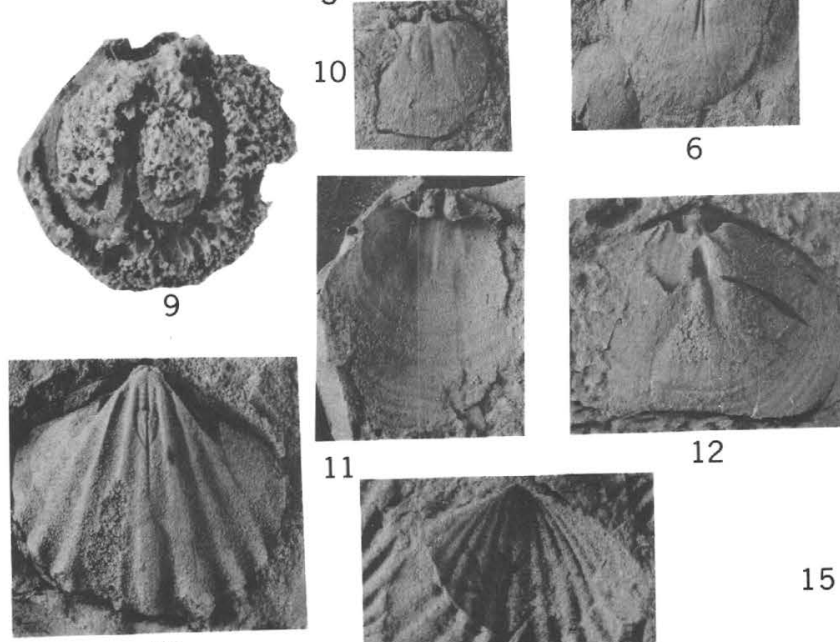

18
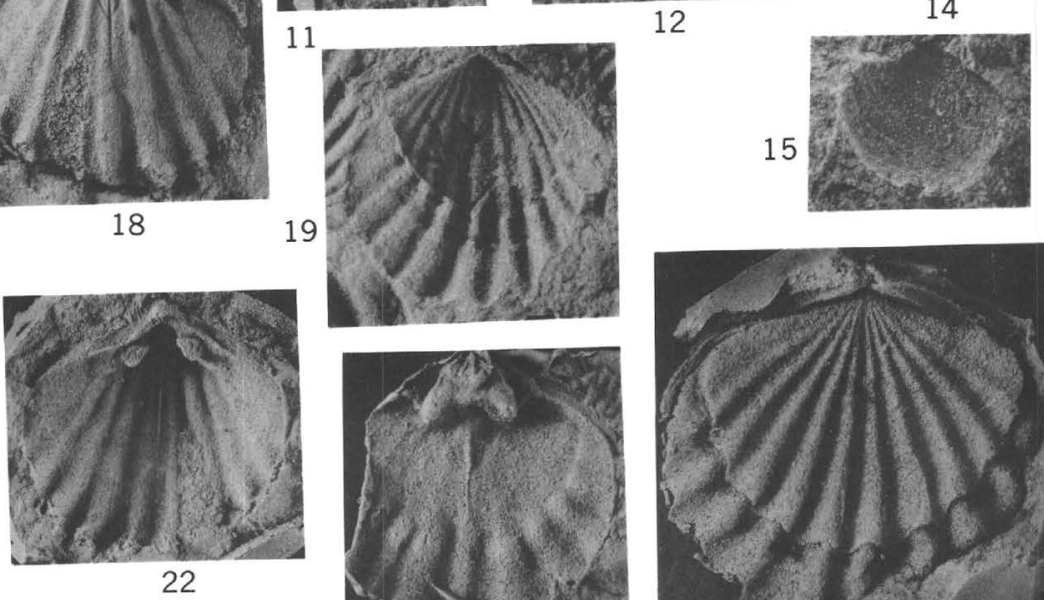

19
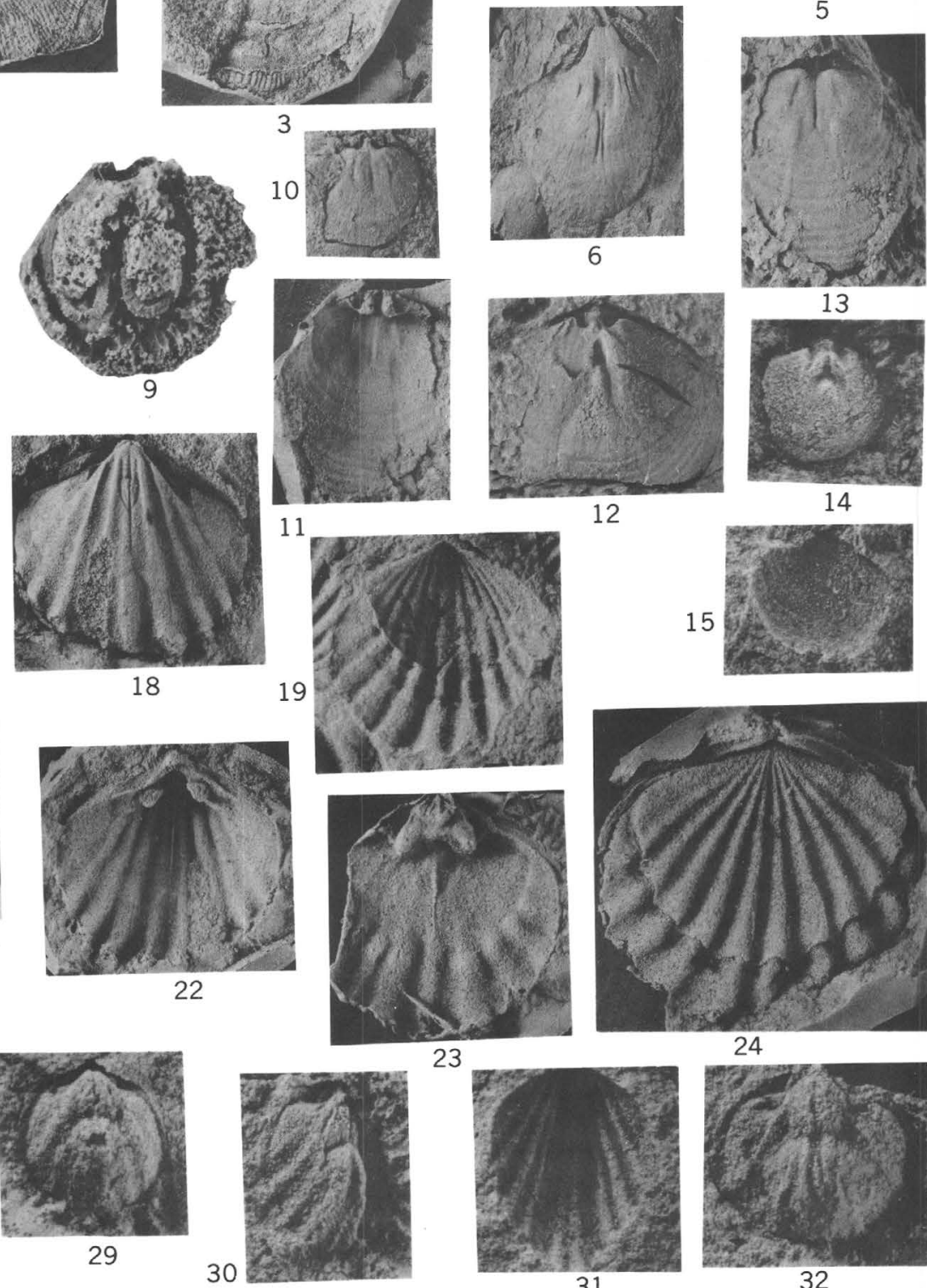

31

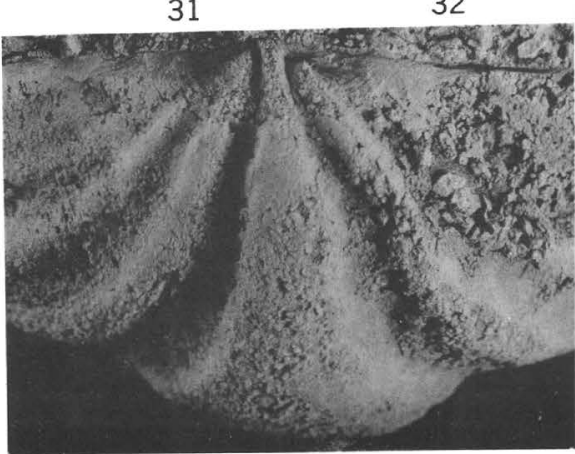

35

ATRYPA, LISSATRYPA, NANOSPIRA?, LEPTOCOELIA, COELOSPIRA, AND HEDEINA 


\section{PLATE 16}

Figures 1-5. Delthyris cf. D. kozlowskii Amsden, 1951 (p. 39).

Base of Hobbstown Formation. USGS loc. 3479-SD, Spencer Lake quadrangle, Somerset County, Maine.

1. Impression of interior of pedicle valve $(\times 2)$. USNM 126038 .

2. Impression of interior of brachial valve $(\times 3$. USNM $126027 \mathrm{~A}$.

3. Latex replica of exterior of pedicle valve $(\times 2)$. USNM $126036 \mathrm{~B}$.

4. Impression of exterior of pedicle valve $(\times 6)$. USNM $126036 \mathrm{~B}$.

5. Impression of interior of pedicle valve $(\times 2)$. USNM $126025 \mathrm{~B}$.

6, 7. Howellella? sp. (p. 39).

6. Cross section $(\times 3)$, showing presence of short dental lamellae and absence of a median septum. USNM 160134. Hardwood Mountain Formation. USGS loc. 4841-SD, Attean quadrangle, Somerset County, Maine.

7. Impression of interior of pedicle valve $(\times 3)$. USNM 126020 . Hardwood Mountain Formation. USGS loc. 2950-SD, Spencer Lake quadrangle, Somerset County, Maine.

8, 9. Howellella? cf. H. cyclopterus (Hall, 1857) (p. 40).

Latex replica and impression of exterior of pedicle valve $(\times 1)$. USNM 126257A. Beck Pond Limestone. USGS loc. 3499-SD, Spencer Lake quadrangle, Somerset County, Maine.

10-18. "Howellella" tomheganensis Boucot, n. sp. (p. 40).

Tomhegan Formation. USGS loc. 2750-SD, Brassua Lake quadrangle, Somerset County, Maine.

10. Latex replica of interior of pedicle valve $(x 1)$. USNM $126017 \mathrm{~B}$

11. Latex replica of interior of brachial valve $(\times 2)$. USNM $126032 \mathrm{~B}$.

12. Latex replica of exterior of brachial valve $(\times 1)$. Holotype, USNM 126016B.

13. Impression of interior of brachial valve, posterior view ( $X$ 2). Holotype, USNM 126016A.

14. Impression of interior of brachial valve $(X 1)$. Holotype, USNM 126016A.

15. Latex replica of exterior of pedicle valve $(\times 2)$. USNM $126026 \mathrm{~A}$.

16. Impression of interior of pedicle valve $(x 3)$. USNM $125026 \mathrm{~A}$.

17, 18. Latex replica and impression of interior of pedicle valve $(\times 2)$. USNM 126045B, A.

19-25. Acrospirifer murchisoni (Castelnau, 1843) (p. 41).

Lower sandstone of Tarratine Formation. USGS loc. 2718-SD,

Long Pond quadrangle, Somerset County, Maine. $\times 1$.

19. Latex replica of exterior of pedicle valve. USNM 126047A.

20, 23. Latex replica and impression of interior of pedicle valve. USNM $126047 \mathrm{D}$.

21, 24. Latex replica and impression of interior of brachial valve. USNM 126043.

22. Latex replica of exterior of brachial valve. USNM 127386B.

25. Impression of interior of pedicle valve. USNM 126042A. 
GEOLOGICAL SURVEY

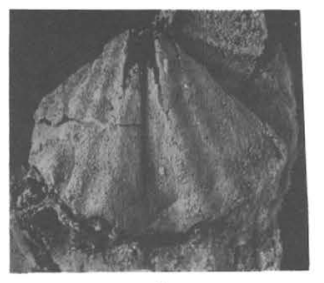

1
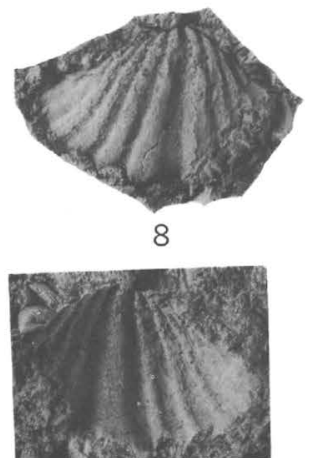

9

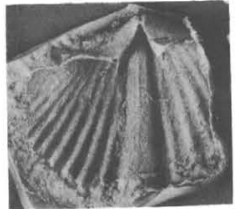

10

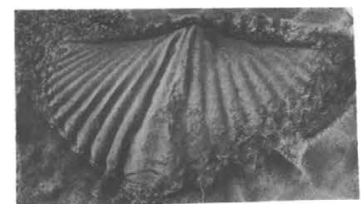

14

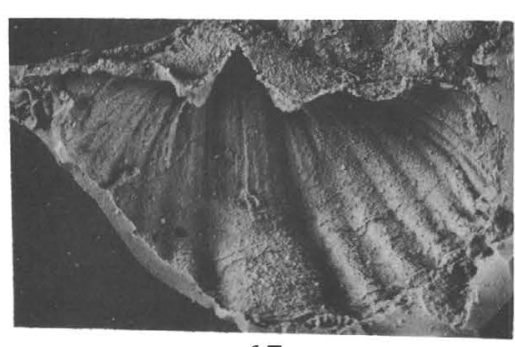

17

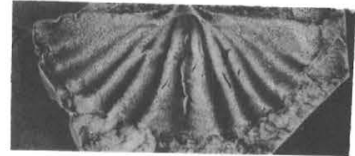

21

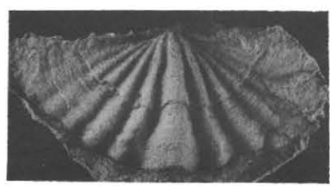

22

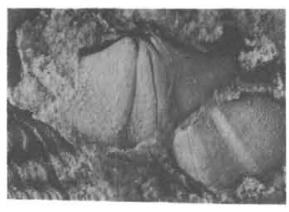

2
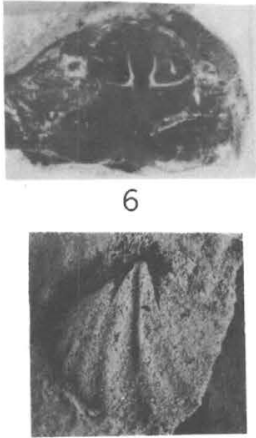

7

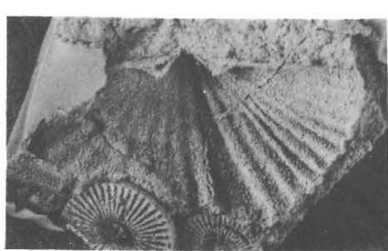

11

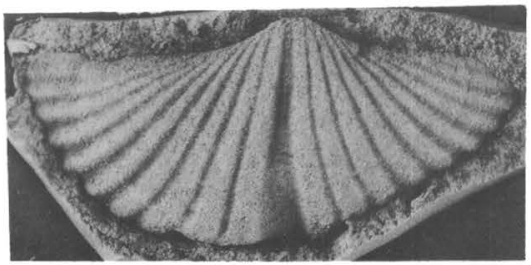

15

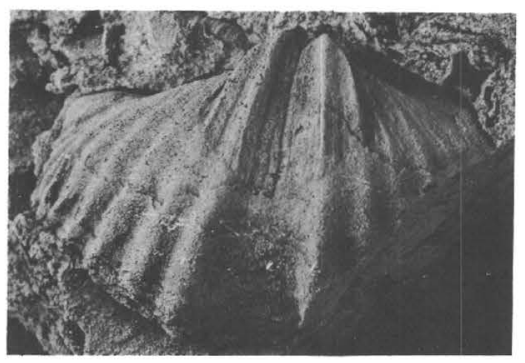

18

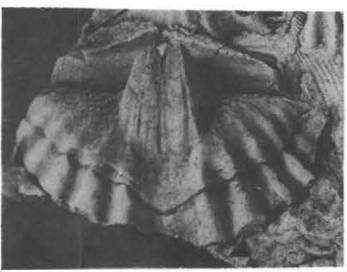

23

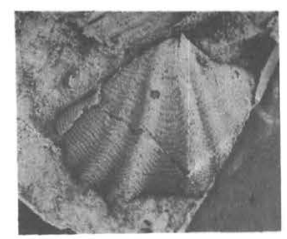

3

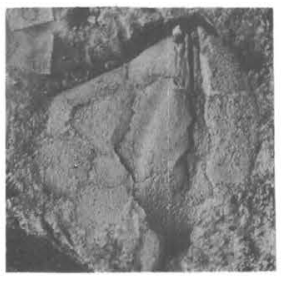

5

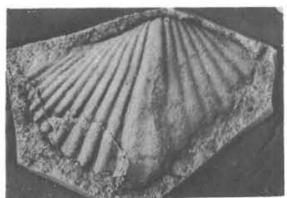

12

PROFESSIONAL PAPER 784 PLATE 16

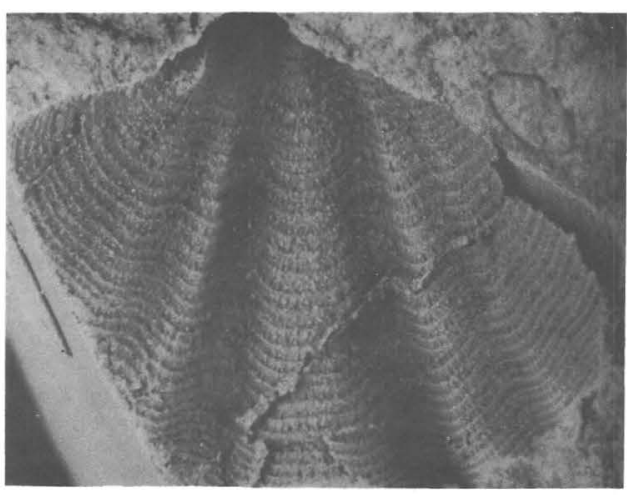

4

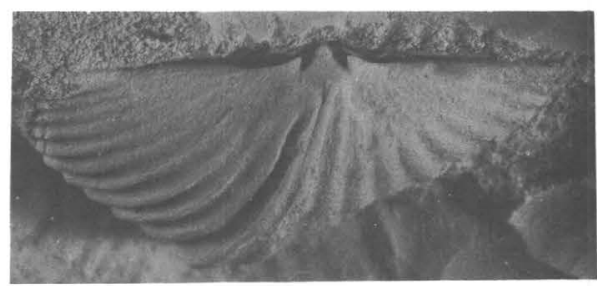

13

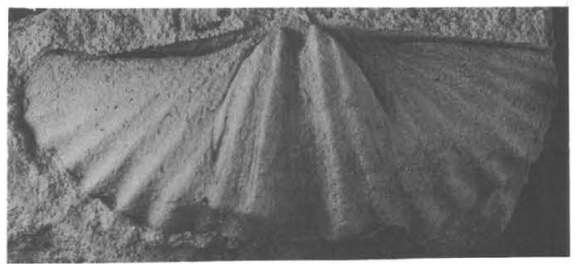

16

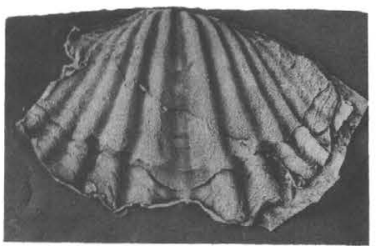

19
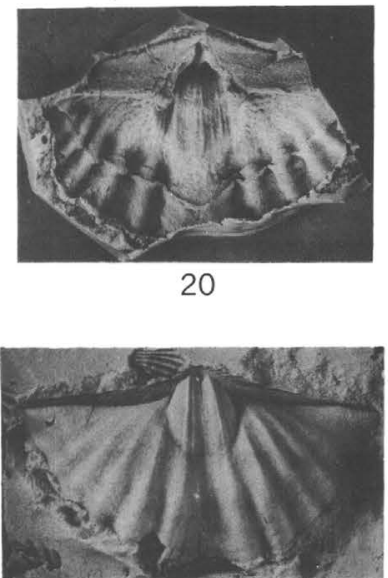

25

DELTHYRIS, HOWELLELLA?, "HOWELLELLA", AND ACROSPIRIFER 


\section{PLATE 17}

Figures 1-9. Acrospirifer atlanticus (Clarke, 1907) (p. 46).

Tomhegan Formation. Brassua Lake quadrangle, Somerset County, Maine.

1, 2. Impression and latex replica of interior of brachial valve $(\times 1)$. USNM 126041B. USGS loc. 2750-SD.

3. Latex replica of exterior of brachial valve $(\times 1)$. USNM 126041A. USGS loc. 2750-SD.

4, 9. Latex replica of exterior of brachial valve $(\times 1, \times 4)$. USNM 126163B. USGS loc. 2750-SD.

5, 6. Impression and latex replica of interior of pedicle valve ( $\times 1)$. USNM 126019B. USGS loc. 2820-SD.

7. Latex replica of interior of pedicle valve $(X 1)$. USNM 127388B. USGS loc. 2750-SD.

8. Impression of interior of pedicle valve $(\times 1)$. USNM 126031B. USGS loc. 2820-SD.

10-14. Acrospirifer sp. 1 (p. 47).

Lower sandstone of Tarratine Formation. USGS loc. 2796-SD,

Pierce Pond quadrangle, Somerset County, Maine. $\times 1$

10, 13. Impression and latex replica of interior of brachial valve. USNM 126090.

11, 12. Latex replica and impression of interior of pedicle valve. USNM 126075.

14. Latex replica of exterior of brachial valve. USNM 126090. 
GEOLOGICAL SURVEY

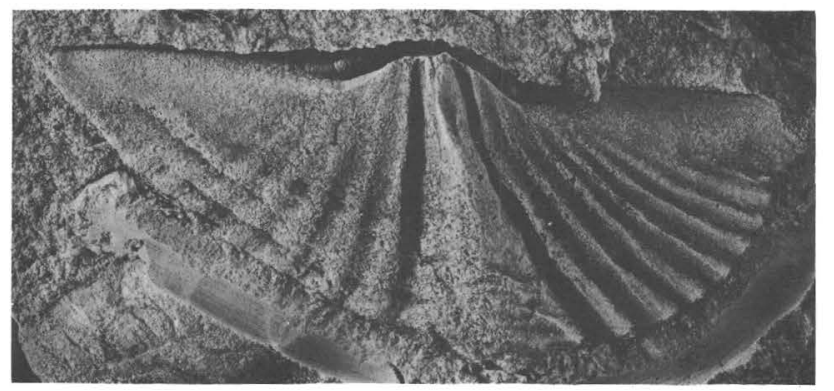

1

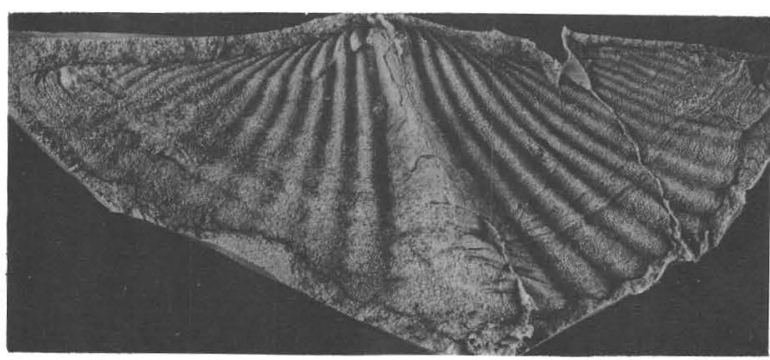

3

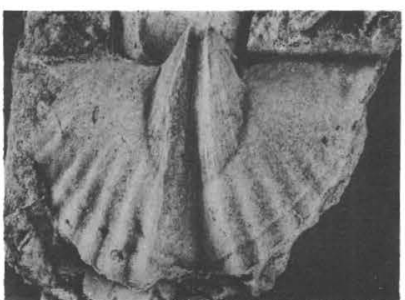

5

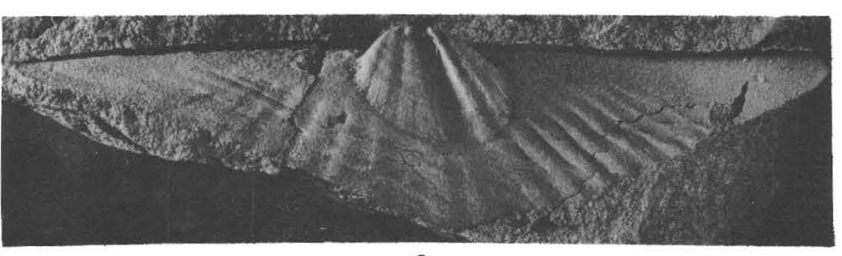

8

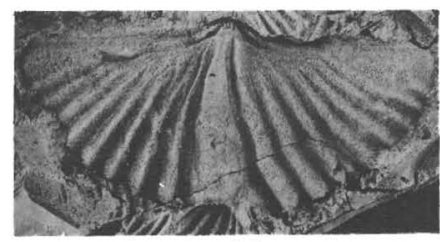

10

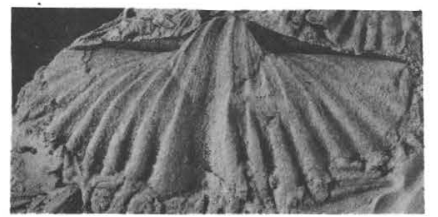

12

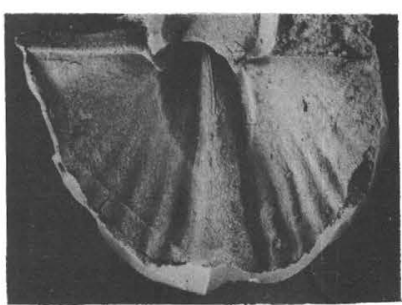

6

PROFESSIONAL PAPER 784 PLATE 17

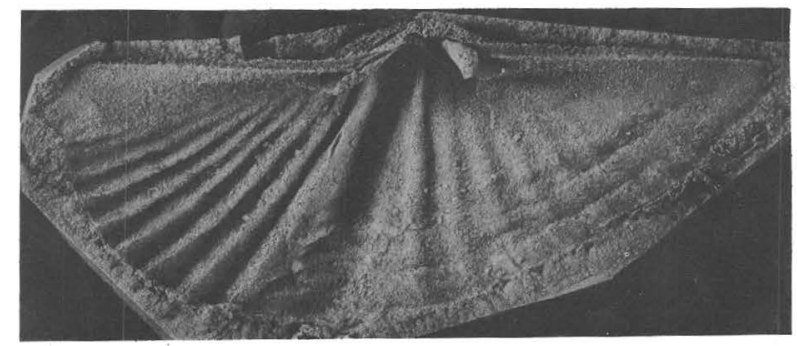

2

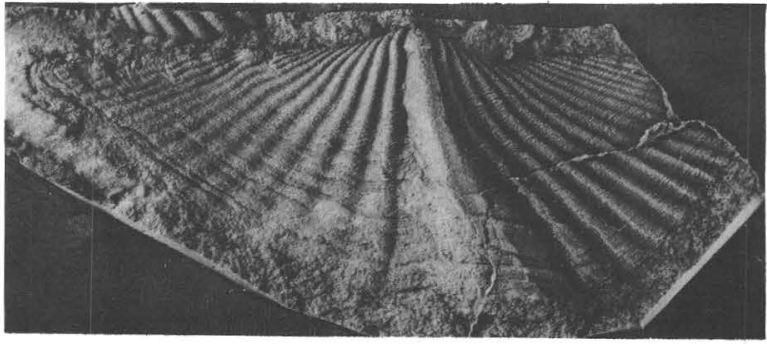

4

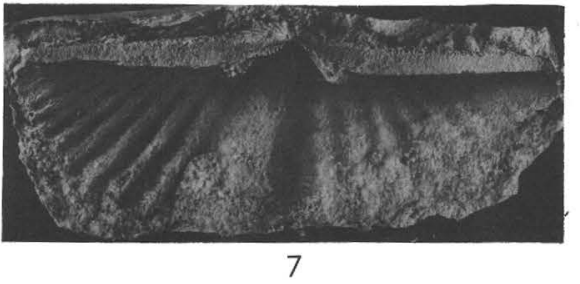

7

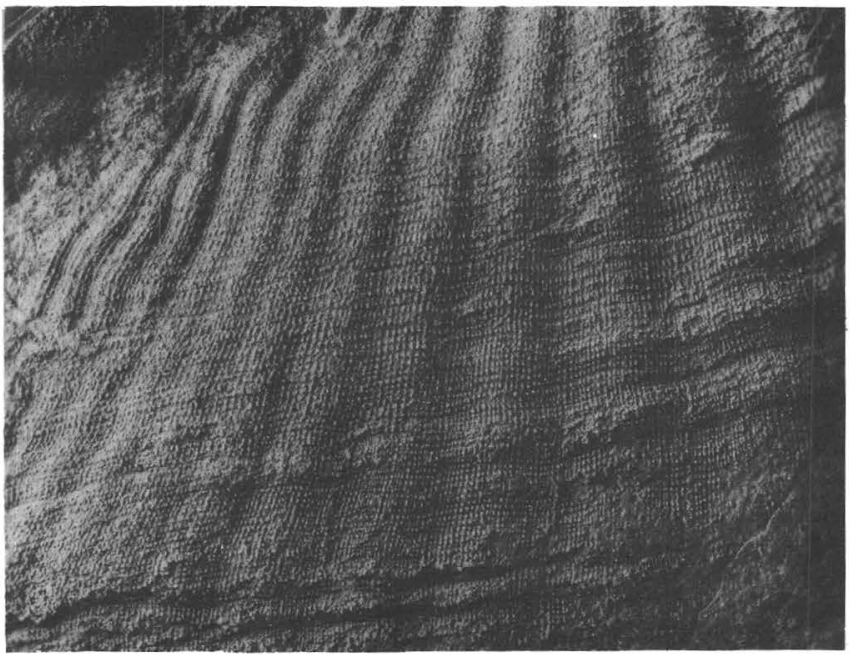

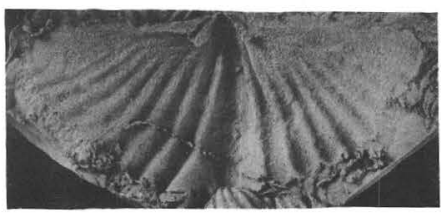

13

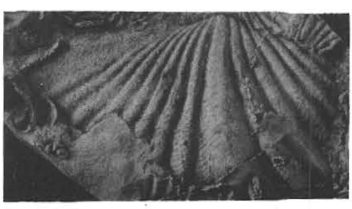

14 


\section{PLATE 18}

Figures 1-5. Acrospirifer sp. 2 (p. 48).

Lower sandstone of Tarratine Formation. USGS loc. 2872-SD,

Pierce Pond quadrangle, Somerset County, Maine.

1,2. Latex replica $(\times 3)$ and impression $(X 1)$ of interior of pedicle valve. USNM 126113.

3. Latex replica of exterior of brachial valve $(\times 1)$. USNM 126089B.

4, 5. Latex replica and impression of interior of brachial valve $(\times 1)$. USNM 126089A.

6-14. Antispirifer harroldi Williams and Breger, 1916 (p. 50).

Lower sandstone of Tarratine Formation. Long Pond quadrangle,

Somerset County, Maine.

6. Impression of interior of brachial valve $(x 1)$. USNM 126039. USGS loc. 2720-SD.

7. Impression of interior of pedicle valve $(\times 1)$. USNN 126040. USGS loc. 2721-SD.

8, 10. Latex replica $(X 1)$ and impression $(X 3)$ of exterior of brachial valve. USNM 126024B. USGS loc. 2721-SD.

9. Latex replica of exterior of pedicle valve $(\times 2)$. USNM 126028A. USGS loc. 2722-SD.

11. Impression of interior of brachial valve $(\times 2)$. USNM 126034B. USGS loc. 2720-SD.

12, 14. Latex replica and impression of interior of brachial valve $(\times 2)$. USNM 126034B. USGS loc. 2720-SD.

13. Latex replica of exterior of pedicle valve $(X, 2)$. USNM 126033B. USGS loc. 2720-SD.

15-20. Costellispirifer perimele (Clarke, 1907) (p. 51).

Tomhegan Formation. USGS loc. 2750-SD, Brassua Lake quadrangle, Somerset County, Maine.

15. Impression of interior of pedicle valve $(X 1)$. USNM $126029 \mathrm{~B}$.

16. Latex replica of exterior of brachial valve $(X 2)$. USNM $126037 \mathrm{~A}$.

17. Latex replica of exterior of pedicle valve $(x 1)$. USNM $126035 \mathrm{~A}$

18, 19. Latex replica and impression of interior of brachial valve $(\times 1)$. USNM 126030B.

20. Impression of interior of pedicle valve $(X 1)$. USNM $126035 \mathrm{~B}$.

21, 22. "Mucrospirifer"cf. "M." macra (Hall, 1857) (p. 60).

Ventral and posterior views of internal mold $(\times 2)$. USNM

160135. Tomhegan Formation. USGS loc. 2723-SD, Brassua

Lake quadrangle, Somerset County, Maine.

23-26. Costispirifer sp. (p. 61).

23, 25. Latex replica of exterior and impression of interior of pedicle valve $(\times 1)$. USNM 126023B, A. Seboomook Formation. USGS loc. 3482-SD, Spencer Lake quadrangle, Somerset County, Maine.

24,26 . Impression of interior and latex replica of exterior of brachial valve $(\times 1)$. USNM 126018B, A. Lower sandstone of Tarratine Formation. USGS loc. 2767-SD, Moosehead Lake quadrangle, Somerset County, Maine. 
GEOLOGICAL SURVEY

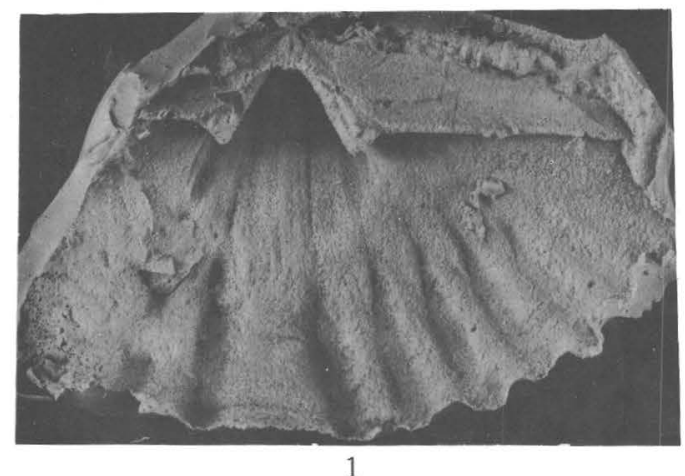

1
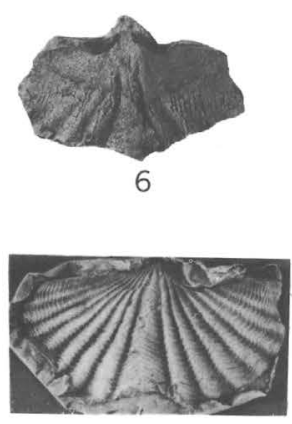

8

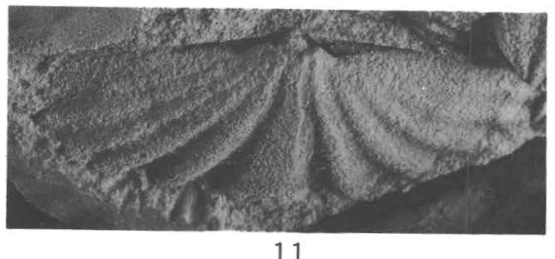

11

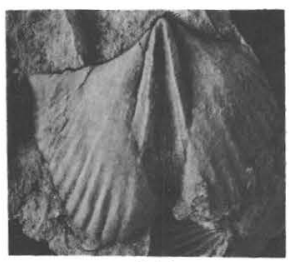

15

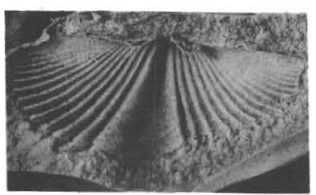

18

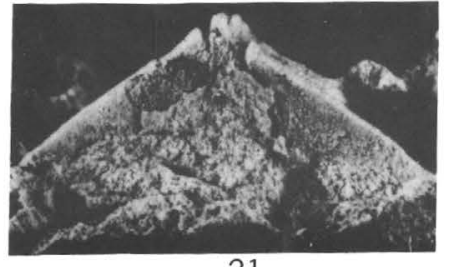

21

16

19

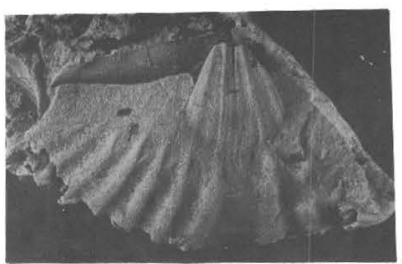

2

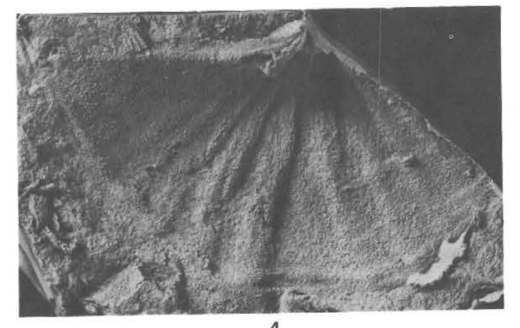

4
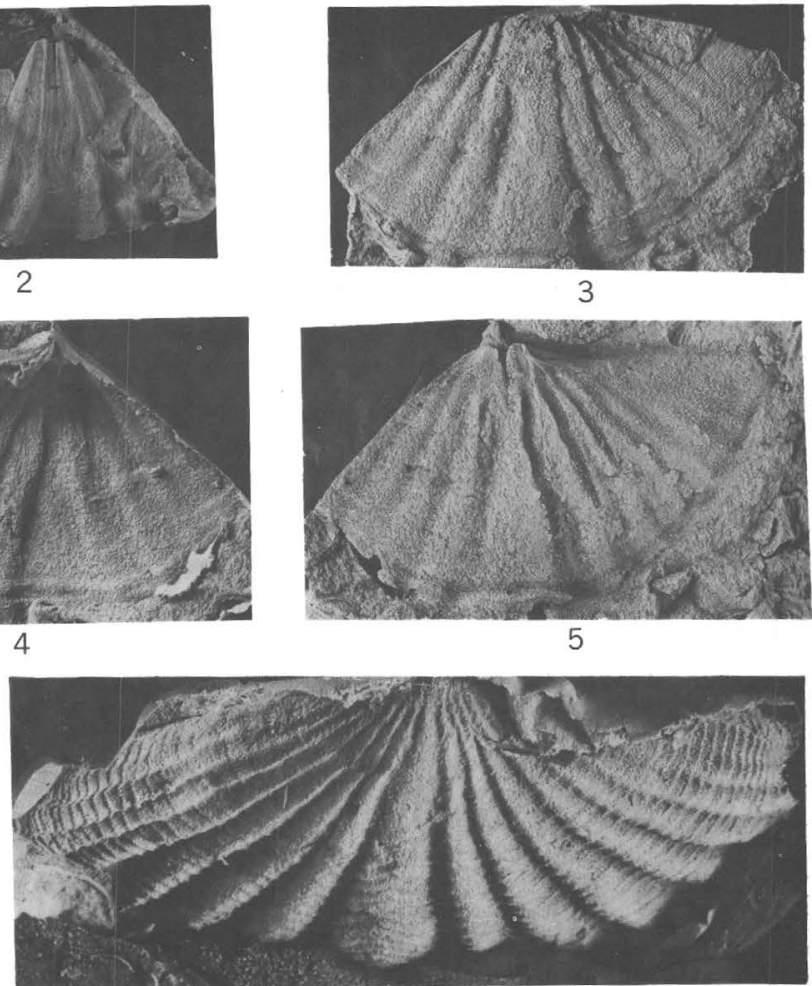

3
PROFESSIONAL PAPER 784 PLATE 18
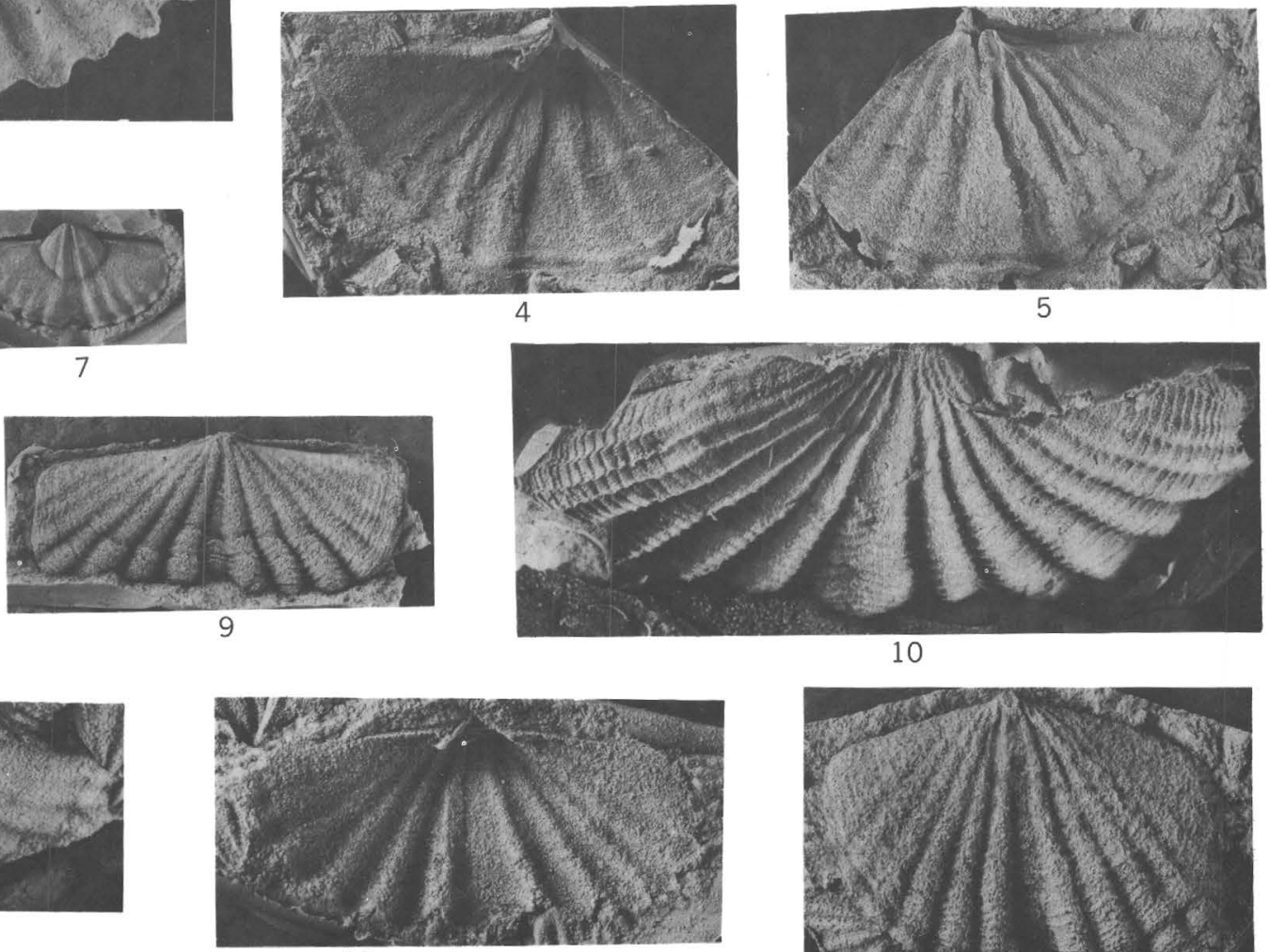

12
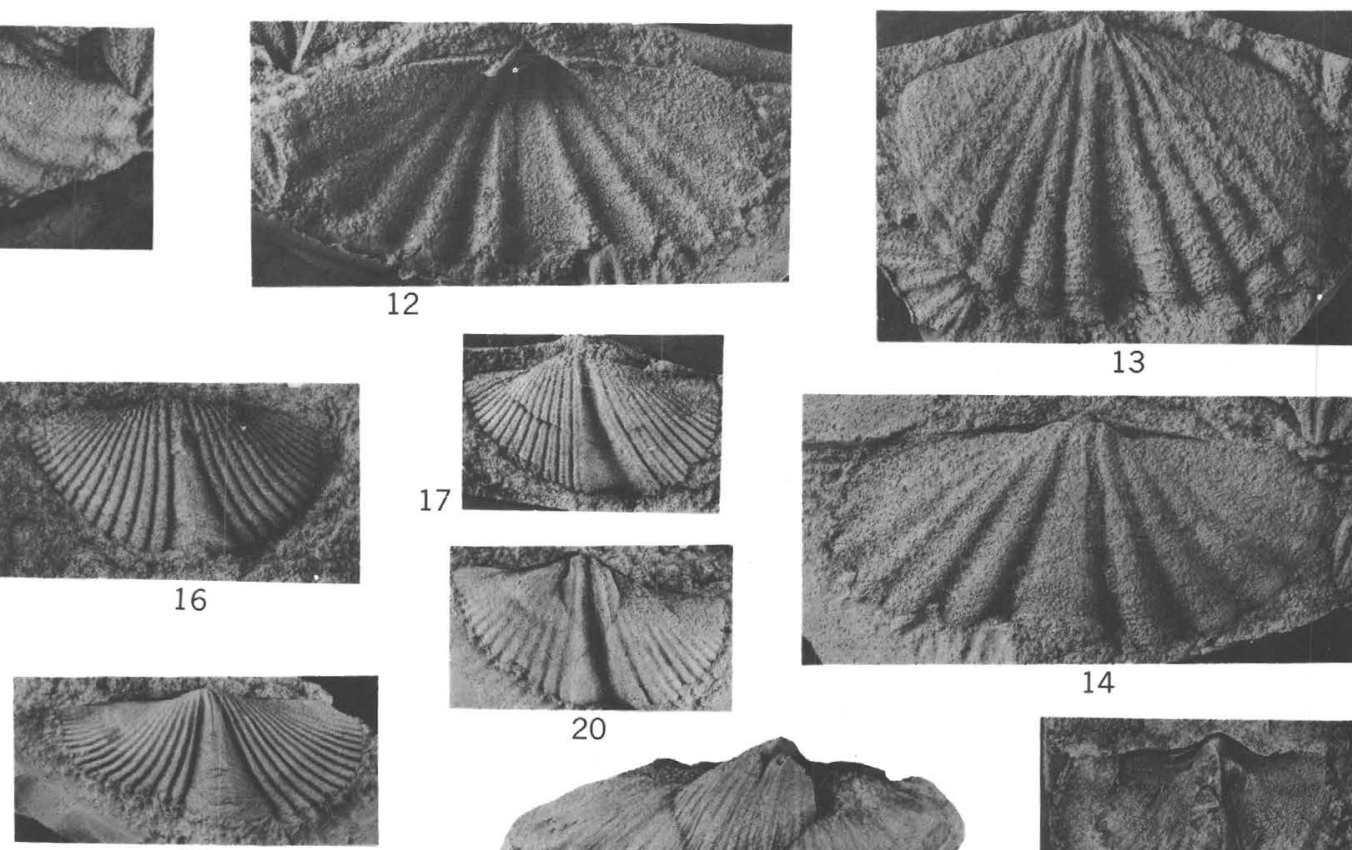

13

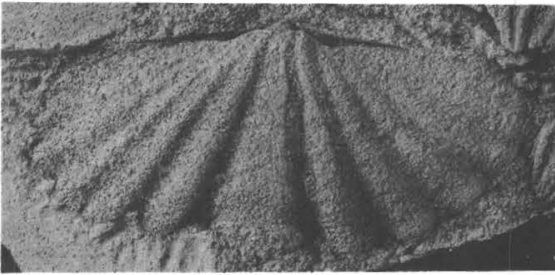

14

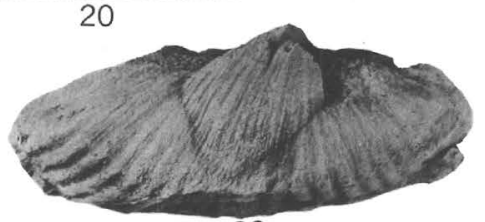

23

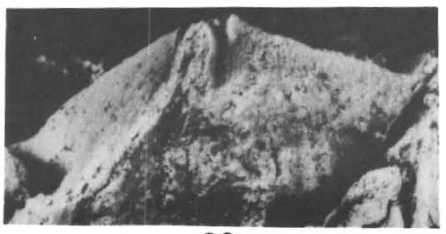

22

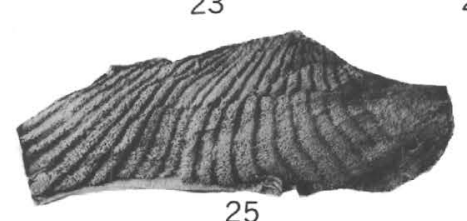

25

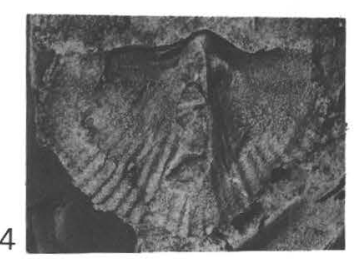

26

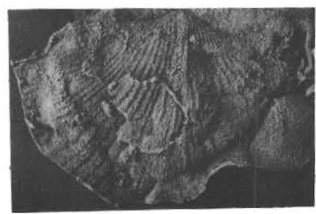

ACROSPIRIFER, ANTISPIRIFER, COSTELLISPIRIFER, “MUCROSPIRIFER”, AND COSTISPIRIFER 


\section{PLATE 19}

Figures 1-6. Megakozlowskiella sp. (p. 62).

Beck Pond limestone. Spencer Lake quadrangle, Somerset County, Maine. $\times 2$.

1. Impression of interior of pedicle valve. USNM $126044 \mathrm{~B}$. USGS loc. 3497-SD.

2-6. Exterior: brachial valve, pedicle valve, side view, posterior view, and anterior view. USNM 126046. USGS loc. 3601-SD.

7-11. Metaplasia cf. M. paucicostata (Schuchert, 1913) (p. 62).

McKenney Ponds Member of Tarratine Formation. USGS loc. 2806-SD, Pierce Pond quadrangle, Somerset County, Maine.

7. Latex replica of exterior of pedicle valve $(\times 3)$. USNM $126115 \mathrm{~A}$.

8, 9. Impression of interior of brachial and pedicle valves ( $X$ 4). USNM 126115B.

10, 11. Latex replica $(\times 3)$ and impression of interior of pedicle valve. USNM $126115 \mathrm{C}$.

12-18. Metaplasia minuta Boucot, 1959 (p. 62).

Tomhegan Formation. USGS loc. 2750-SD, Brassua Lake quadrangle, Somerset County, Maine.

12. Latex replica of exterior of pedicle valve (posterior view $\times 4)$. USNM 126110B.

13, 17. Impression and latex replica of interior of brachial valve $(\times 4)$. USNM 126086A.

14. Latex replica of exterior of pedicle valve $(X 3)$. USNM $126067 \mathrm{~A}$.

15. Impression of interior of pedicle valve $(\times 3)$. USNM 126067B.

16. Impression of interior of pedicle valve (posterior view ( $X$ 4). USNM 126110C.

18. Latex replica of exterior of brachial valve $(\times 4)$. USNM 126086B.

19-29. Plicoplasia plicata (Weller, 1903) (p. 63).

19-28. Lower sandstone of Tarratine Formation USGS loc. 2813SD, Pierce Pond quadrangle, Somerset County, Maine.

19. Latex replica of exterior of brachial valve $(X$ 2). USNM 126114A.

20. Latex replica of exterior of pedicle valve $(\times 2)$. USNM 126087A.

21. Impression of interior of pedicle valve $(X 2)$. USNM $126087 \mathrm{~B}$.

22. Impression of interior of brachial valve $(\times 2)$. USNM 126114B.

23. Latex replica of interior of brachial valve $(X$ 3). USNM 126106.

24, 25. Latex replica and impression of interior of pedicle valve $(\times 3)$. USNM 126260 .

26, 27. Latex replica and impression of interior of pedicle valve $(\times 3)$. USNM 126259 .

28. Latex replica of exterior of pedicle valve $(X$ $3)$. USNM 126087A.

29. Impression of interior of brachial valve $(\times 3)$. Seboomook Formation. USGS loc. 2884-SD, Chesuncook quadrangle, Picataquis County, Maine. USNM 126256B.

30-32. Cyrtina? cf. C. rostrata (Hall, 1857), (p. 63).

Brachial, posterior, and side views of internal mold $(\times 2)$. USNM 160136. Seboomook Formation. USGS loc. 2883-SD, Spencer Lake quadrangle, Somerset County, Maine. 
GEOLOGICAL SURVEY
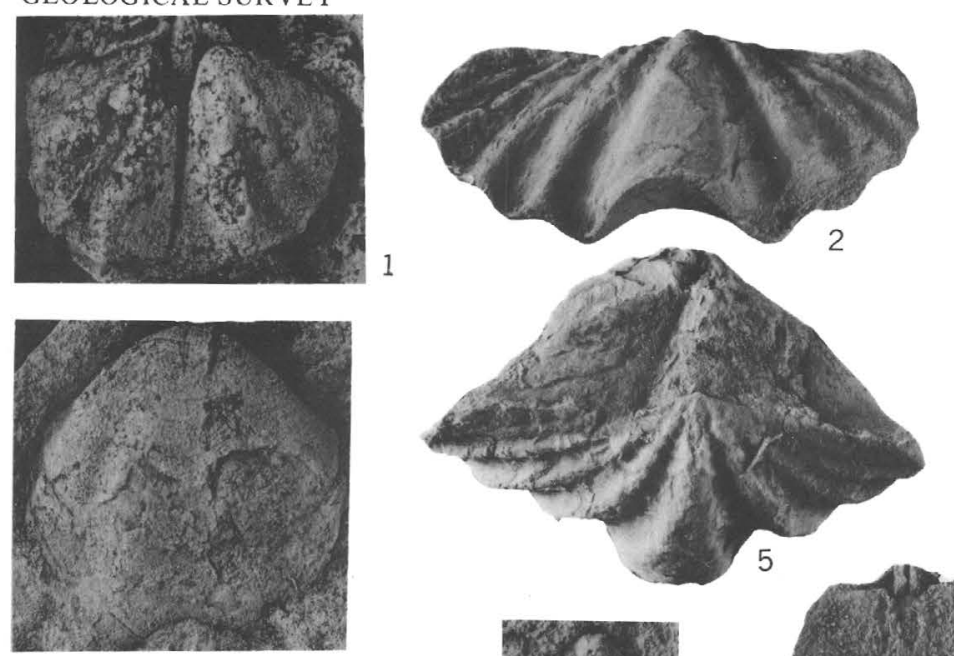

7
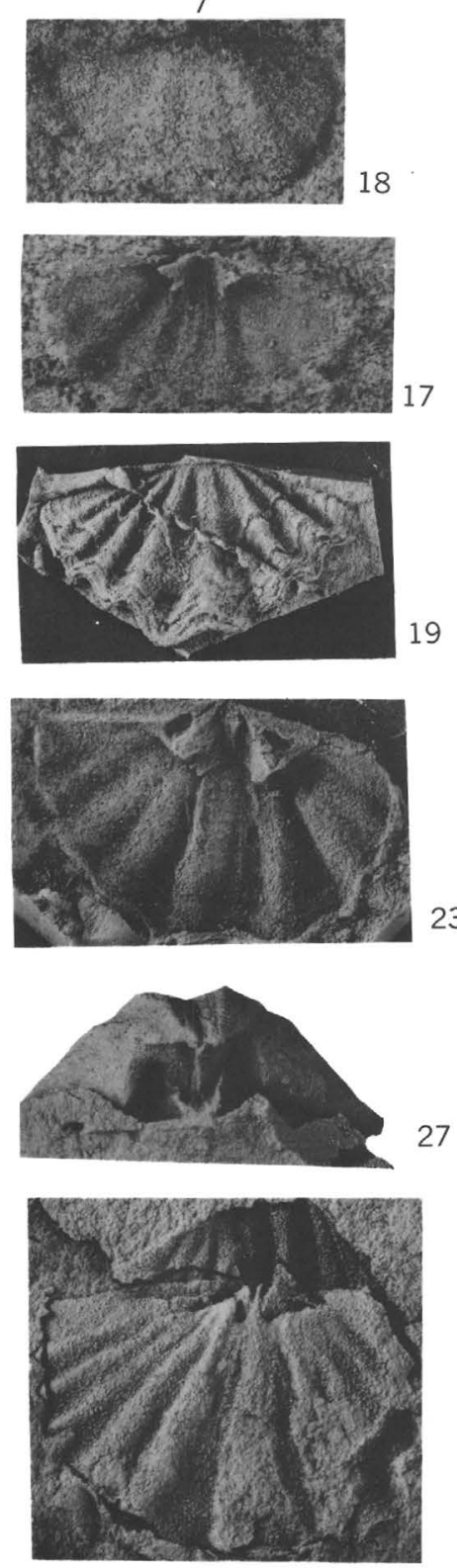

29
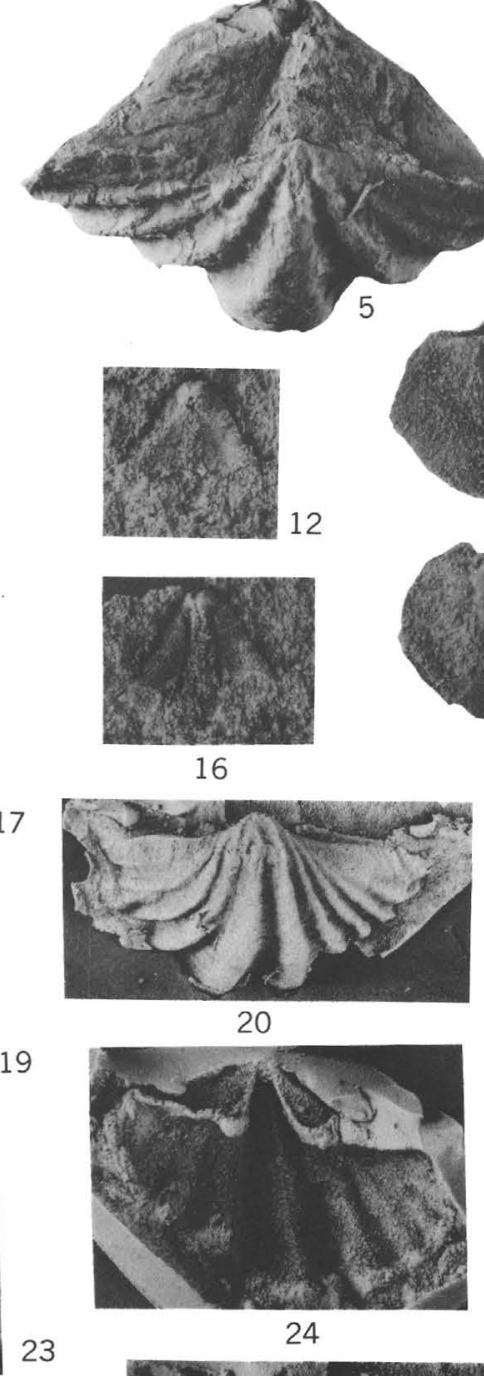

24

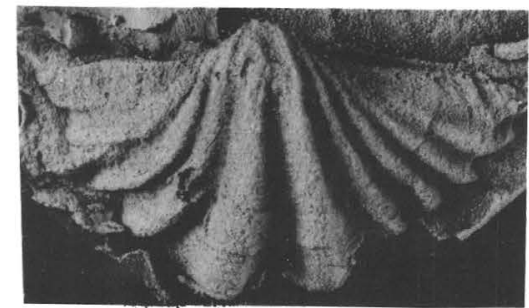

28

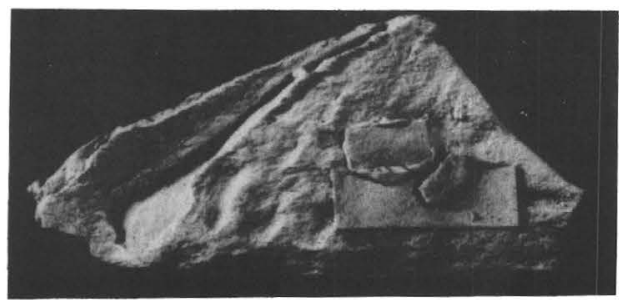

30

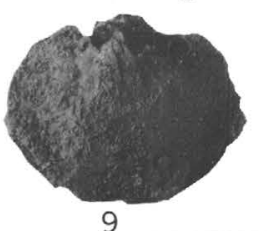

PROFESSIONAL PAPER 784 PLATE 19

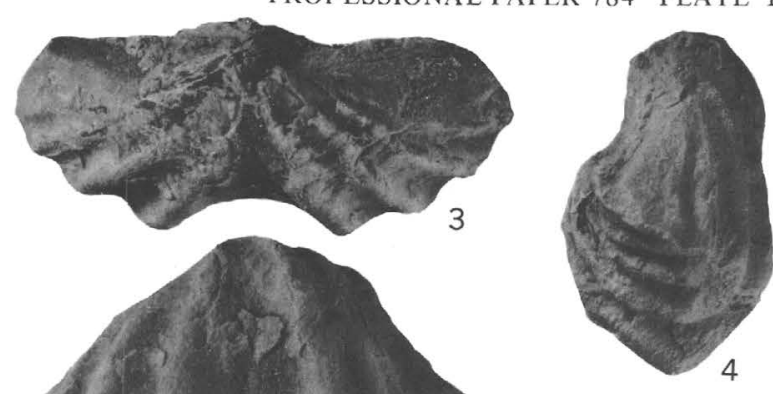

4

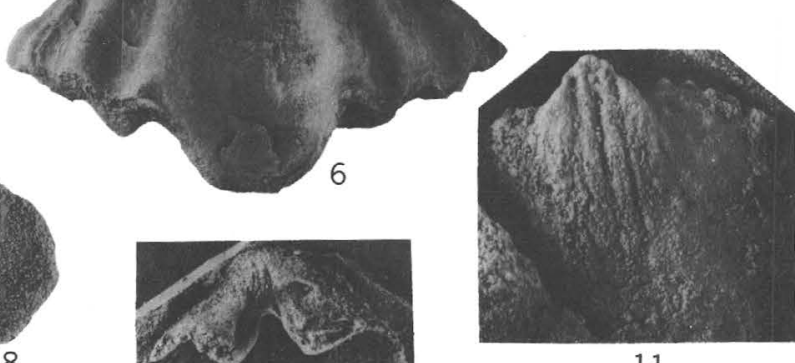

11

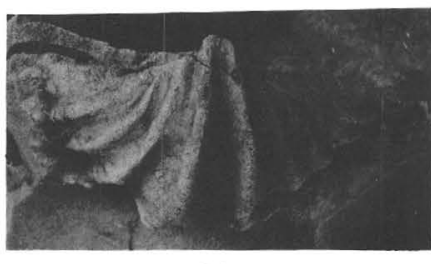

21

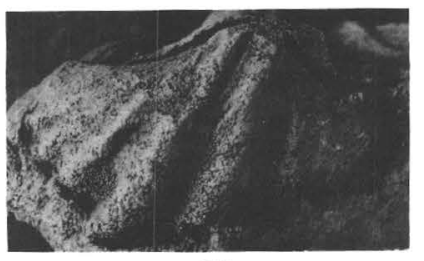

25

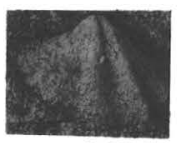

13

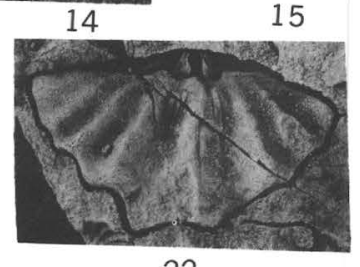

22
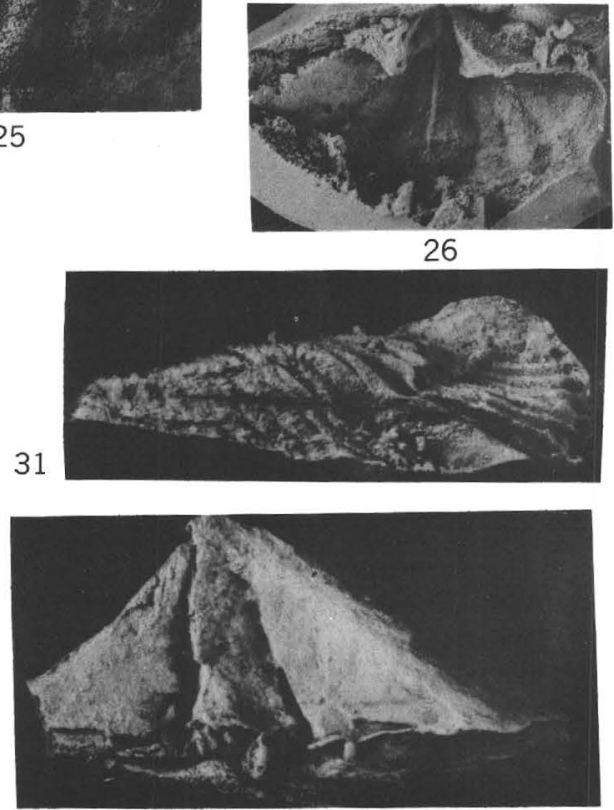

32

MEGAKOZLOWSKIELLA, METAPLASIA, PLICOPLASIA, AND CYRTINA? 


\section{PLATE 20}

Figures 1-6. Merista cf. M. tennesseensis Hall and Clarke, 1895 (p. 63).

Hardwood Mountain Formation. USGS loc. 3488-SD, Spencer Lake quadrangle, Somerset County, Maine.

1-4. Exterior: side, anterior, posterior, and pedicle valve valve (partly exfoliated) views $\left(X^{1} 1\right)$. USNM 126105B.

5. Impression of interior of pedicle valve $(\times 2)$. USNM 126085.

6. Exterior of brachial valve ( $\times 1)$. USNM $126105 \mathrm{~B}$.

7-13. Meristella lata (Hall, 1859), (p. 64).

7, 8, 10-12. Lower sandstone of Tarratine Formation. Long Pond quadrangle, Somerset County, Maine.

7. Latex replica of exterior of pedicle valve $(X 1)$. USNM 126116A. USGS loc. 2721-SD.

8. Impression of spire $(X 1)$. USNM 126079A. USGS loc. 2777-SD.

10. Latex replica of interior of pedicle valve ( $\times$ 2). USNM 127390. USGS loc. 2777--SD.

11, 12. Latex replica and impression of interior of brachial valve $(\times 2)$. USNM 126261A.. USGS loc. 2721-SD.

9. Impression of interior of brachial valve $(\times 1)$. USNM 126103. Seboomook Formation. USGS loc. 3482-SD, Spencer Lake quadrangle, Somerset County, Maine.

13. Impression of interior of brachial valve $(\times 2)$. USNM 126082B. Seboomook Formation. USGS loc. 2884-SD, Chesuncook quadrangle, Piscataquis County, Maine.

14-22. Charionoides doris (Hall, 1860), (p. 64).

Tomhegan Formation. Brassua Lake quadrangle, Somerset County, Maine.

14-16. Impression of interior of pedicle and brachial valves and side view $(\times 2)$. USNM 126111B. USGS loc. 2820-SD.

17. Latex replica of beak of pedicle valve $(\times 3)$. USNM 126117B. USGS loc. 2750-SD.

18. Impression of interior of brachial valve $(\times 1)$. USNM 126102. USGS loc. 2750-SD.

19, 20. Latex replica and impression of interior of brachial valve $(\times 2)$. USNM 126081. USGS loc. 2750-SD.

21. Impression of interior of pedicle valve $(X 2)$. USNM 126080A. USGS loc. 2750-SD.

22. Impression of interior of pedicle valve $(\times 2)$. USNM 126092. USGS loc. 2750-SD.

23-27. Nucleospira sp. (p. 65).

Base of Hobbstown Formation. USGS loc. 3479-SD, Spencer Lake quadrangle, Somerset County, Maine.

23,24 . Impression and latex replica of interior of pedicle valve $(\times 3)$. USNM 126091B.

25, 27. Latex replica and impression of interior of brachial valve $(\times 4)$. USNM 126262.

26. Latex replica of exterior of pedicle valve $(X 4)$. USNM $126091 \mathrm{~A}$.

28-37. Protathyris sp. (p. 65).

Hardwood Mountain Formation. USGS loc. 2822-SD, Attean quadrangle, Somerset County, Maine. $\times 2$.

28-31, 33. Exterior: brachial valve, pedicle valve, posterior, anterior, and side views. USNM 126262.

32, 34-37. Exterior: posterior, pedicle valve, side, brachial valve, and anterior views. USNM 126070. 
GEOLOGICAL SURVEY

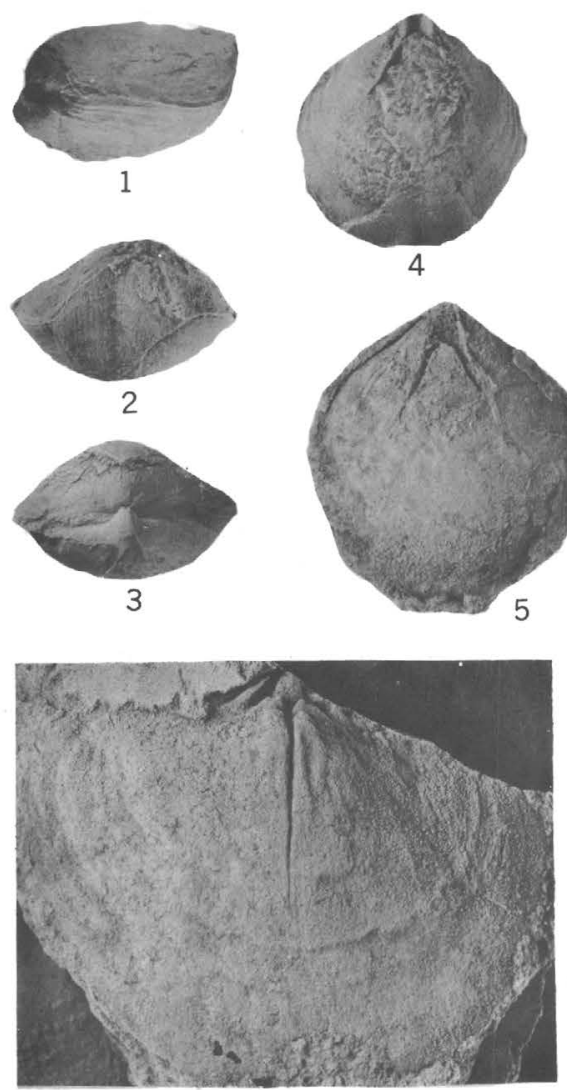

13
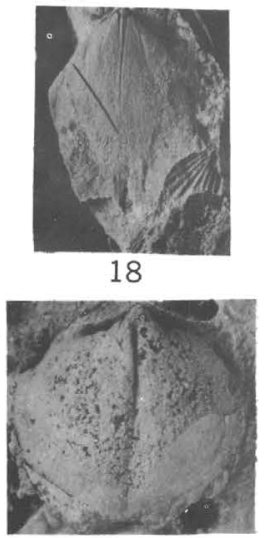

23

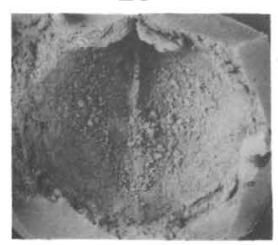

24

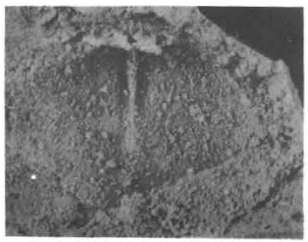

25

26

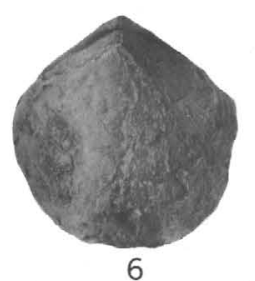

6

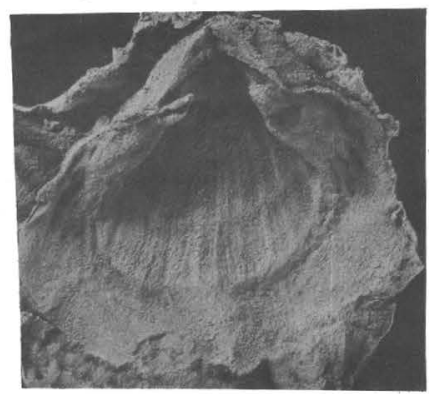

10
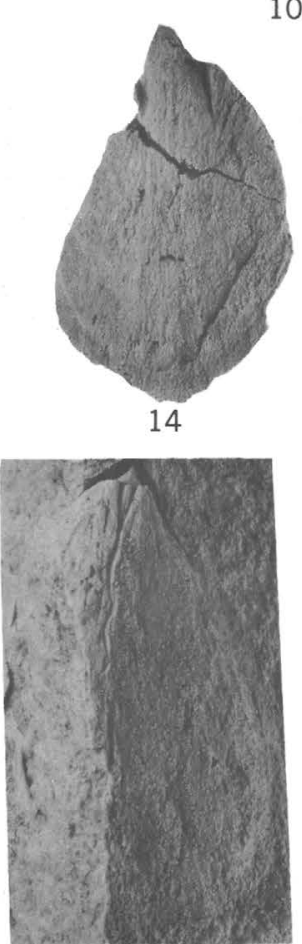

20

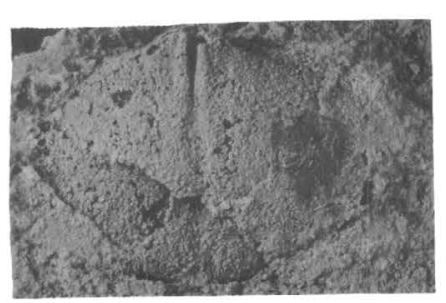

27
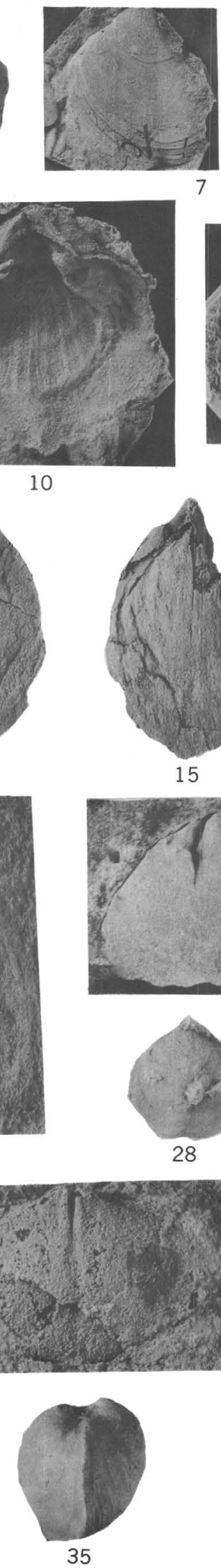

PROFESSIONAL PAPER 784 PLATE 20

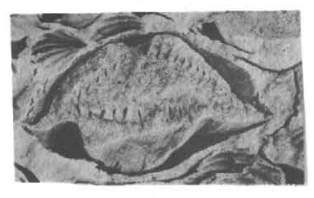

8
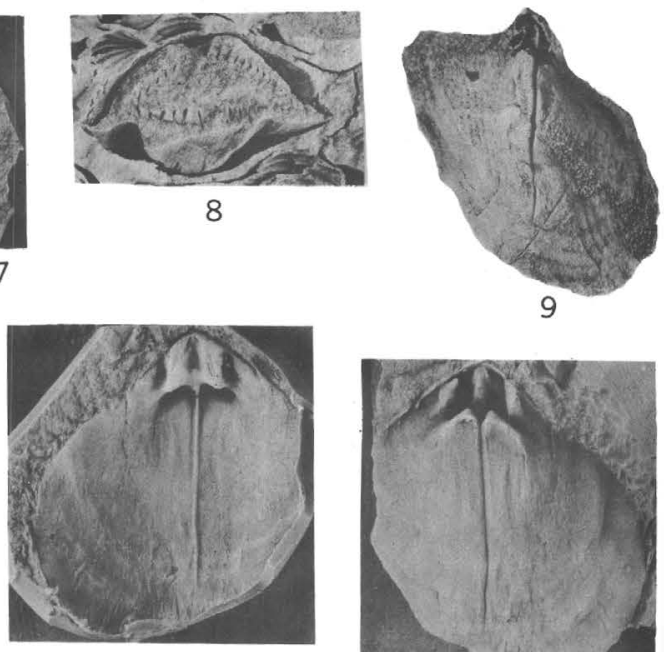

11
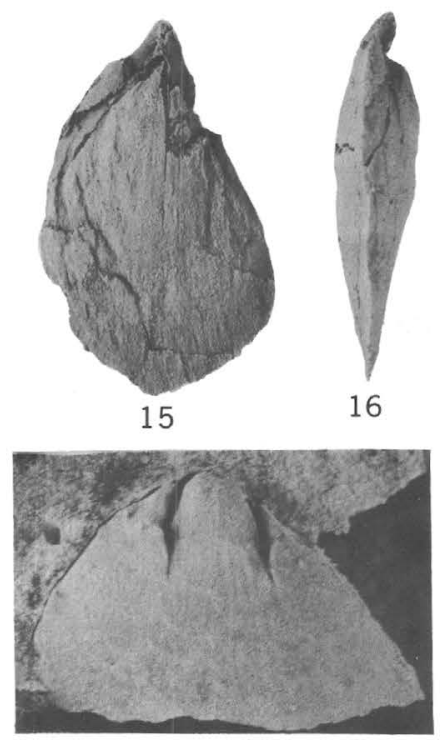

21

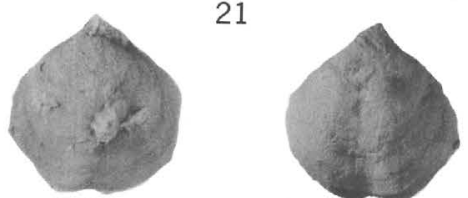

29

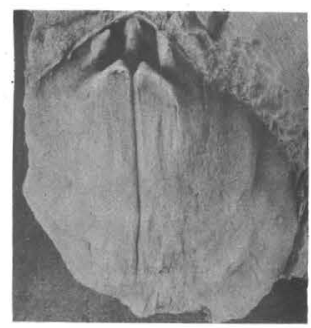

12

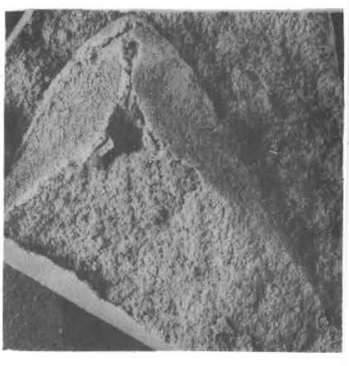

17

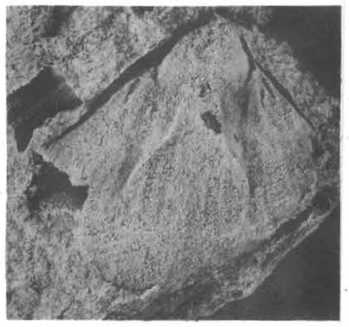

22
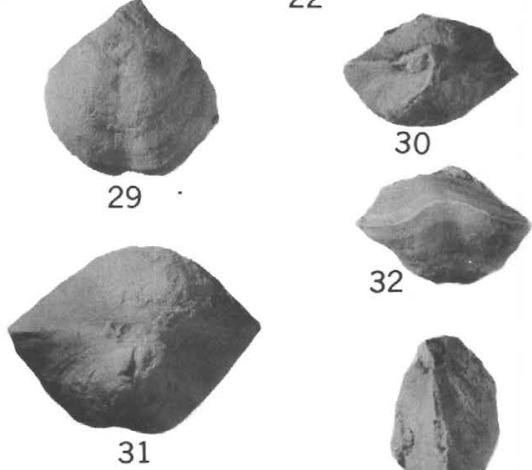

32
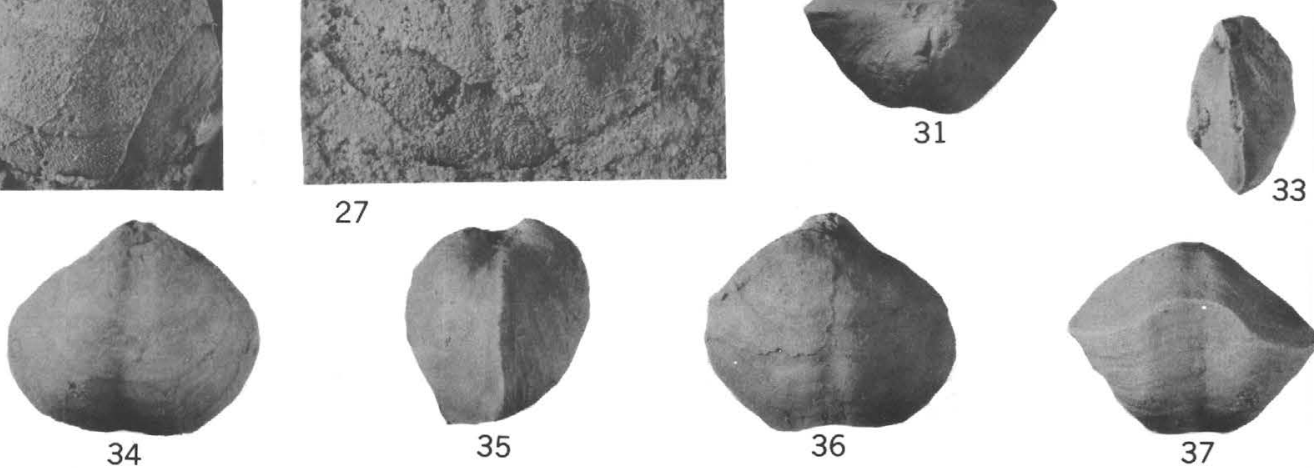

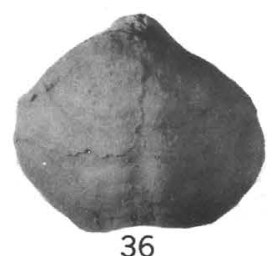




\section{PLATE 21}

Figures 1-6. Nanothyris hodgei Boucot, n. sp. (p. 65).

Lower sandstone of Tarratine Formation. USGS loc. 2832-SD, Brassua Lake quadrangle, Somerset County, Maine.

1. Latex replica of interior of brachial valve $(\times 3)$. Holotype, USNM 126194.

2. Impression of exterior (posterior view $\times 2$ ). Paratype, USNM 125943.

3,4 . Impression of interior of brachial and pedicle valves $(\times 2)$. Paratype, USNM 126191

5. Latex replica of exterior of pedicle valve $(X 3)$. Paratype, USNM $126183 \mathrm{~A}$.

6. Latex replica of exterior of brachial valve $(\times 3)$. Paratype, USNM $126220 \mathrm{~A}$

7-13. Nanothyris cf. N. subglobosa (Weller, 1903) (p. 66).

Beck Pond Limestone. USGS loc. 3601- SD, Spencer Lake quadrangle, Somerset County, Maine.

7-11. Exterior: pedicle valve, brachial valve, side, posterior, and anterior views $(\times 2)$. USNM 126192A.

12. Exterior of pedicle valve $(X 1)$. USNM 126192B.

13. Cross section of brachial valve $(\times 3)$. USNM 126187.

14-17. Rensselaeria sp. (p. 66).

Lower sandstone of Tarratine Formation. USGS loc. 2767-SD, Moosehead Lake quadrangle, Somerset County, Maine. $\times 2$.

14, 15. Impressions of interior of brachial valves. USNM 126216C, D.

16,17 . Impressions of interior of pedicle valves. USNM 126216B, 126214.

18-30. Beachia thunii (Clarke, 1907) (p. 69).

Lower sandstone of Tarratine Formation. Somerset County, Maine.

18, 23-25, 29. Exterior: brachial valve, anterior, side, posterior, and pedicle valve views $(\times 1)$. USNM 126198. USGS loc. 2813-SD, Pierce Pond quadrangle.

19. Impression of interior of pedicle valve $(\times 1)$. USNM 126207B. USGS loc. 2796-SD, Pierce Pond quadrangle.

20. Latex replica of interior of pedicle valve $(X 1)$. USNM 126217C. USGS loc. 2813-SD, Pierce Pond quadrangle.

21. Impression of interior of brachial valve $(X 1)$. USNM 126206A. USGS loc. 2796-SD, Pierce Pond quadrangle.

22. Impression of interior of brachial valve $(X 1)$. USNM 126202. USGS loc. 2813-SD, Pierce Pond quadrangle.

26, 30. Impression and latex replica of interior of pedicle valve $(X 1)$. USNM 126200. USGS loc. 2731-SD, Long Pond quadrangle.

27. Latex replica of interior of brachial valve $(x 1)$. USNM 126199. USGS loc. 2813-SD, Pierce Pond quadrangle.

28. Impression of interior of brachial valve $(x 3)$. USNM 126203. USGS loc. 2813-SD, Pierce Pond quadrangle. 
GEOLOGICAL SUR VEY
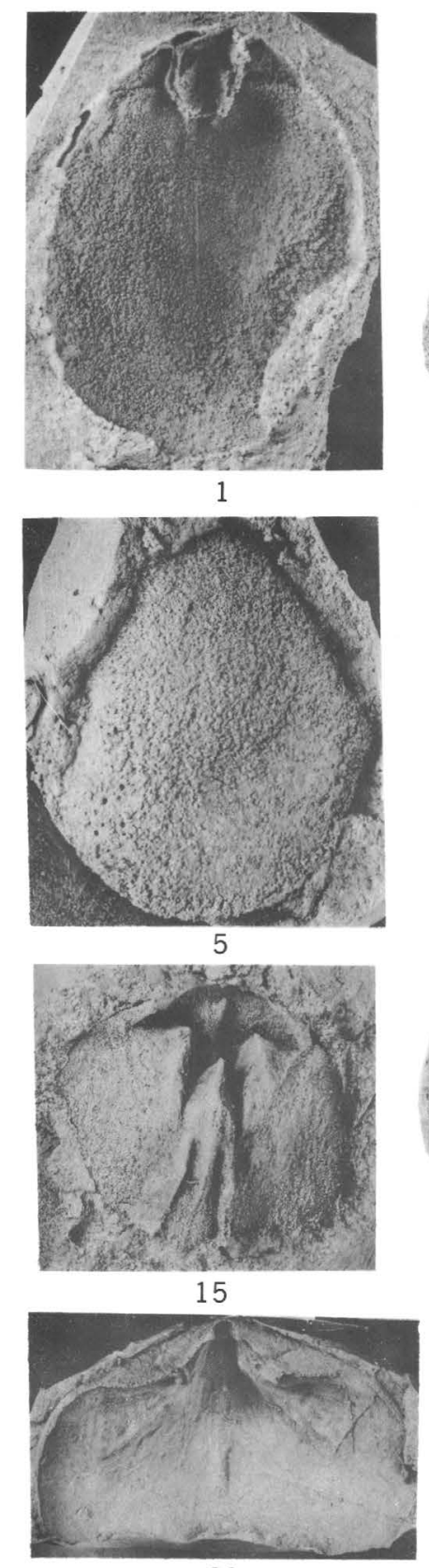

20
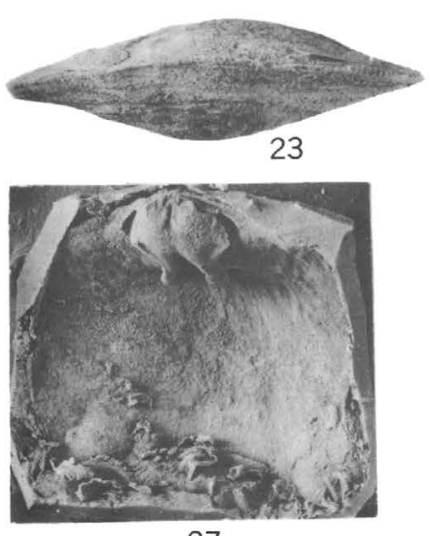

27
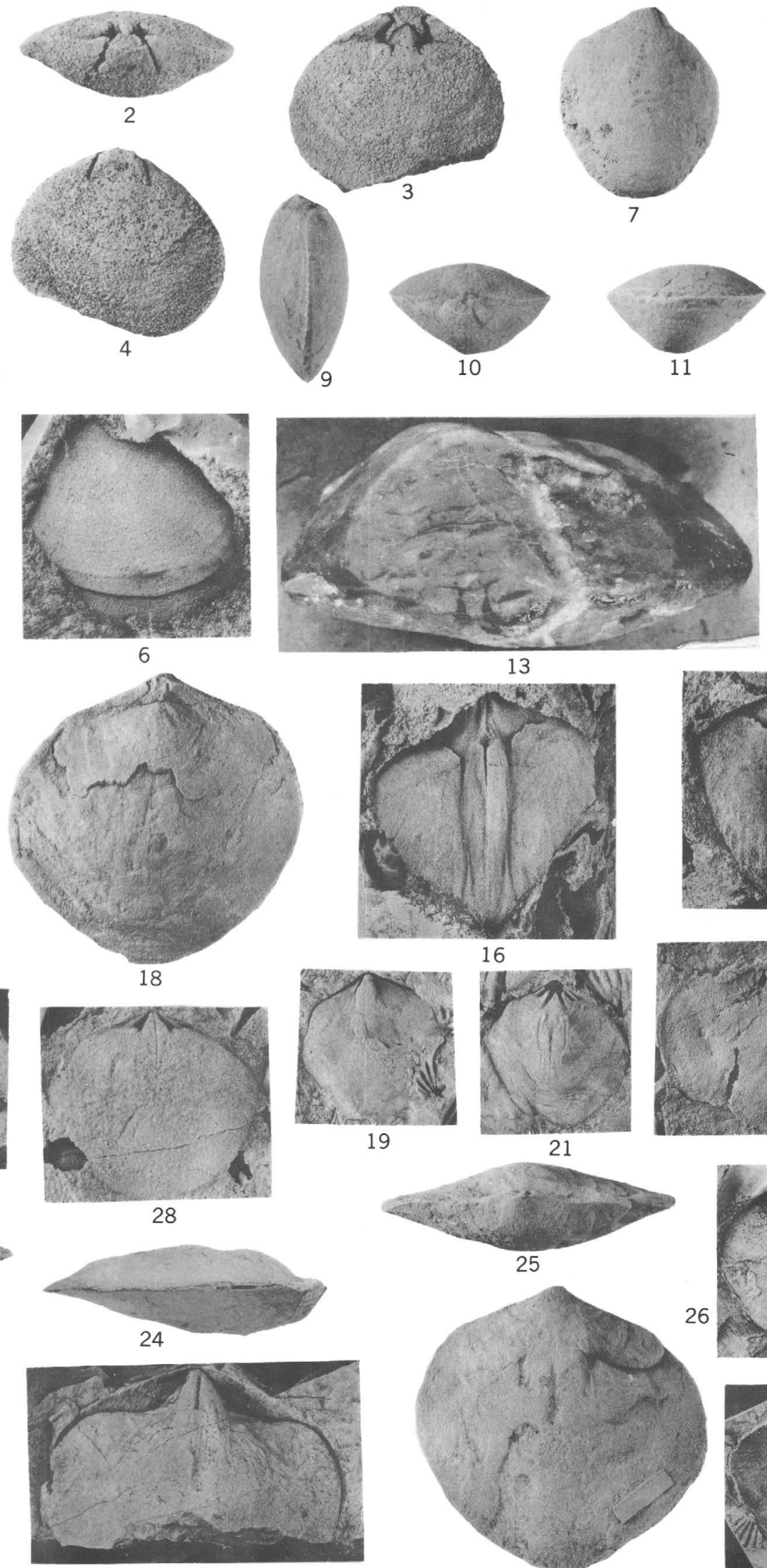

31

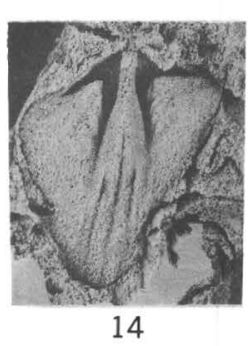

PROFESSIONAL PAPER 784 PLATE 21
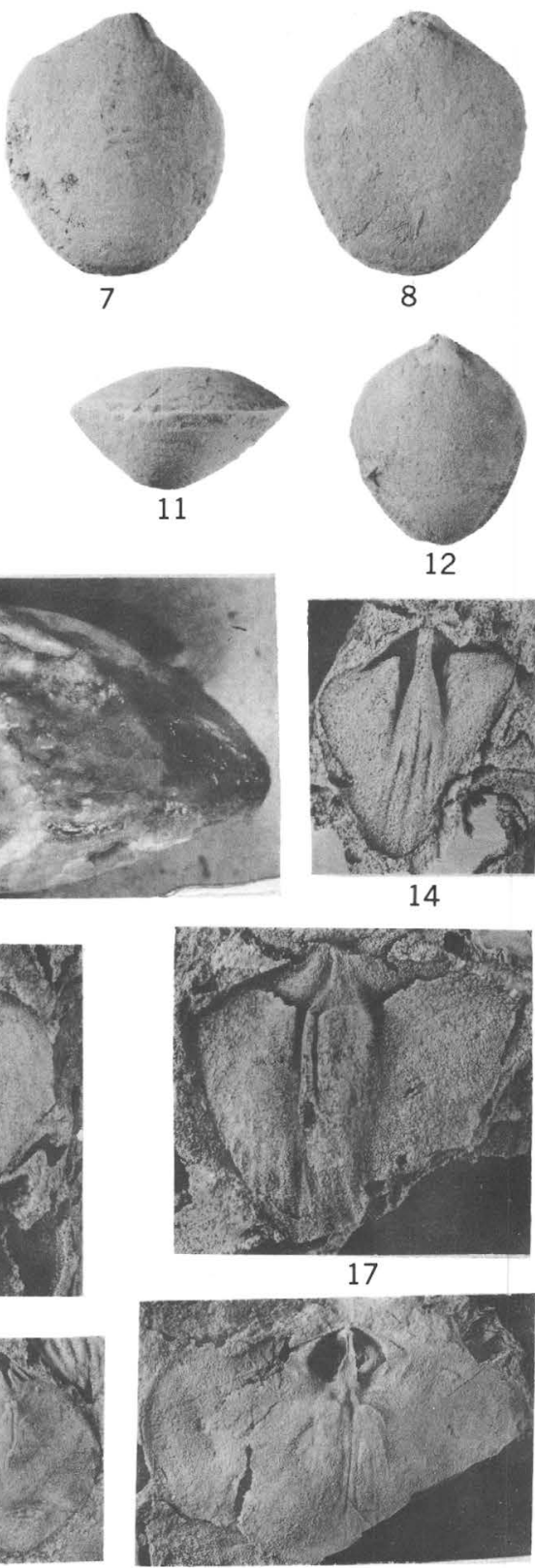

22
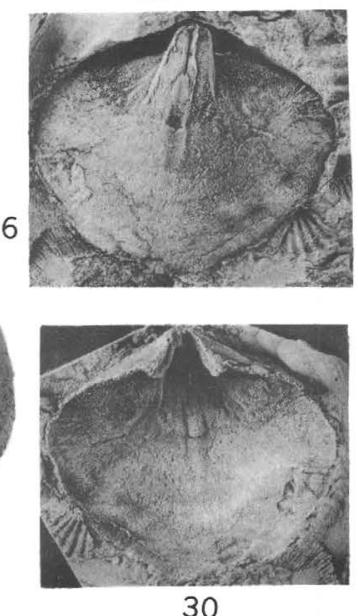


\section{PLATE 22}

Figures 1-5. Beachia thunii (Clarke, 1907) (p. 69).

1. Impression of interior of brachial valve $(x)$ ). NYSM 8436 . Unnamed sandstone. Telos Lake Dam, Telos quadrangle, Piscataquis County, Maine.

2. Impression of interior of brachial valve $(\times 1)$. USNM 126199. Lower sandstone of Tarratine Formation. USGS loc. 2813$\mathrm{SD}$, Pierce Pond quadrangle, Somerset County, Maine.

3. Impression of interior of brachial valve $(\times 1)$. USNM 126204. Seboomook Formation. USGS loc. 2884-SD, Chesuncook quadrangle, Piscataquis County, Maine.

4. Latex replica of interior of pedicle valve $(\times 2)$. USNM 126205. Lower sandstone of Tarratine Formation. USGS loc. 2813SD, Pierce Pond quadrangle, Somerset County, Maine.

5. Impression of exterior of pedicle valve $(\times 2)$. USNM 126209 . Lower sandstone of Tarratine Formation. USGS loc. 2777$\mathrm{SD}$, Long Pond quadrangle, Somerset County, Maine.

6-13. Cloudothyris postovalis Boucot and Johnson, 1968 (p. 69).

Tomhegan Formation. Brassua Lake quadrangle, Somerset County, Maine.

6. Impression of interior of brachial valve $(X 2)$. USNM 126210A. USGS loc. 2750-SD.

7, 12. Impression and latex replica of interior of brachial valve ( $\times$ 2). USNM 126218. USGS loc. 3238-SD.

8, 9. Latex replica and impression of interior of pedicle valve ( $\times 1$ ). USNM 126208A. USGS loc. 2750-SD.

10. Impression of cardinal process $(\times 5)$. USNM 126195. USGS loc. 2814-SD.

11. Latex replica of interior of pedicle valve (posterior view $\times 3)$. USNM 126208A. USGS loc. $2750-S D$.

13. Latex replica of exterior of pedicle valve $(\times 1)$. USNM 126208B. USGS loc. 2750-SD.

14-24. Amphigenia parva Clarke, 1907 (p. 70).

Tomhegan Formation. USGS loc. 2750-SD, Brassua Lake quadrangle, Somerset County, Maine.

14. Impression of interior of pedicle valve (posterior view $\times 2)$. USNM $126193 \mathrm{~B}$.

15. Impression of interior of pedicle valve $(X 1)$. USNM $126190 \mathrm{~A}$.

16. Impression of interior of pedicle valve (posterior view $\times 2$ ). USNM $126196 \mathrm{~A}$.

17. Impression of interior of pedicle valve $(X 1)$. USNM $126219 \mathrm{C}$.

18. Impression of interior of brachial valve $(\times 2)$. USNM $126197 \mathrm{~B}$.

19. Latex replica of exterior of brachial valve $(\times 1)$. USNM $126219 \mathrm{~B}$.

20, 21. Latex replica and impression of interior of brachial valve $(\times 1)$. USNM 126219A.

22. Impression of interior of pedicle valve $(\times 2)$. USNM $126196 \mathrm{~A}$.

23. Impression of interior of brachial valve $(X 2)$. USNM $126188 \mathrm{~A}$.

24. Latex replica of interior of pedicle valve $(X 2)$. USNM 127389. 
GEOLOGICAL SURVEY

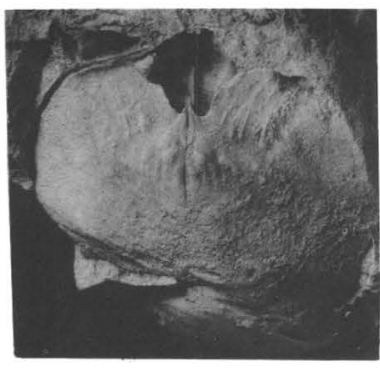

1

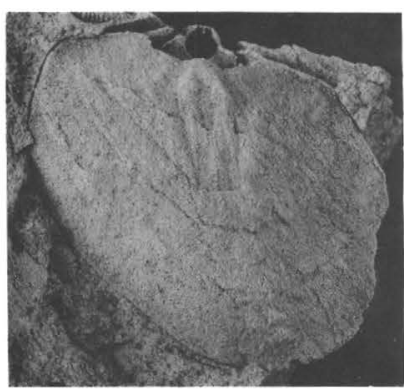

6

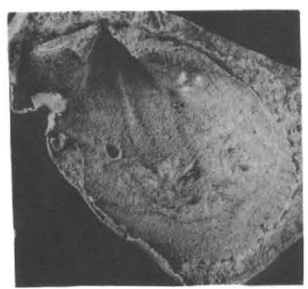

8
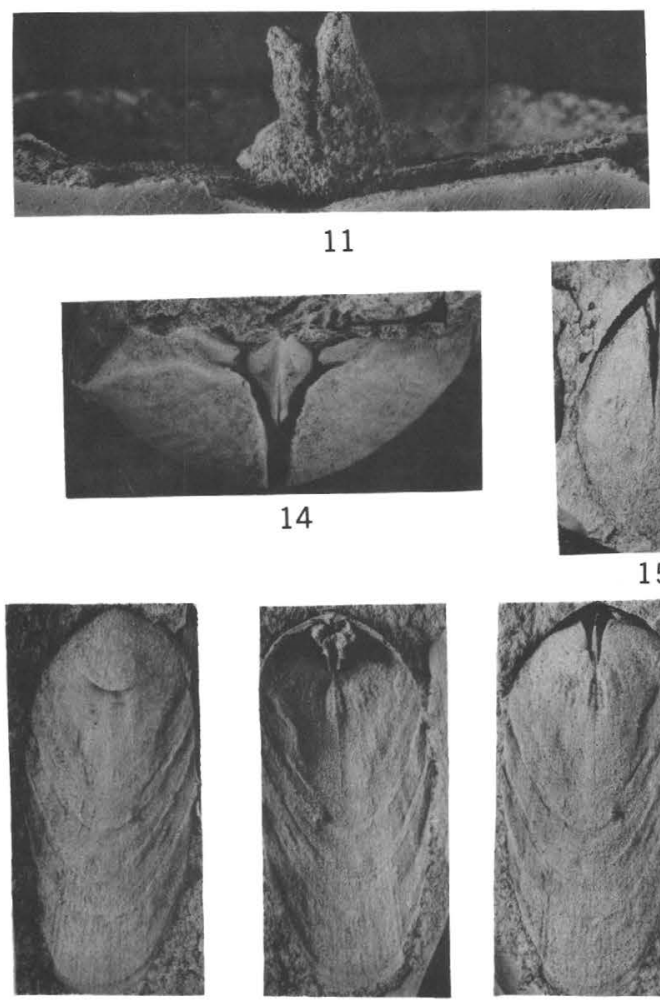

19
11

14

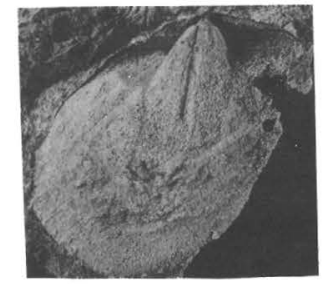

9

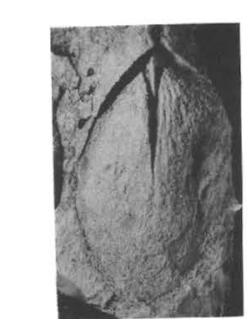

15

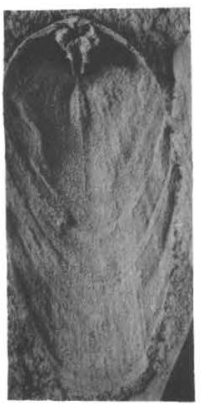

20

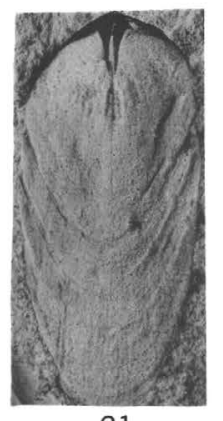

21

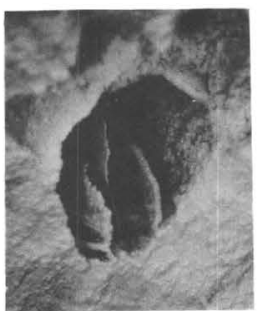

10

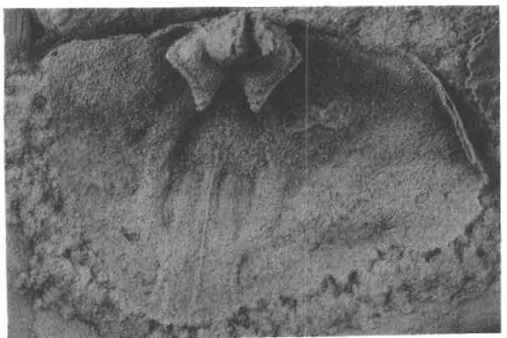

12

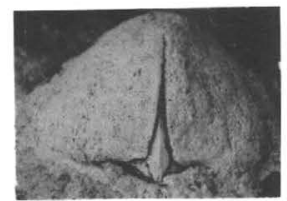

16

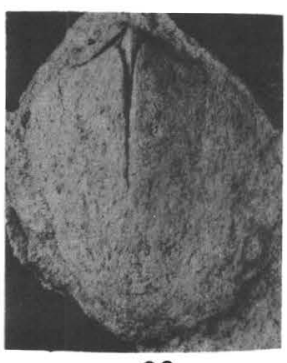

22

23
PROFESSIONAL PAPER 784 PLATE 22
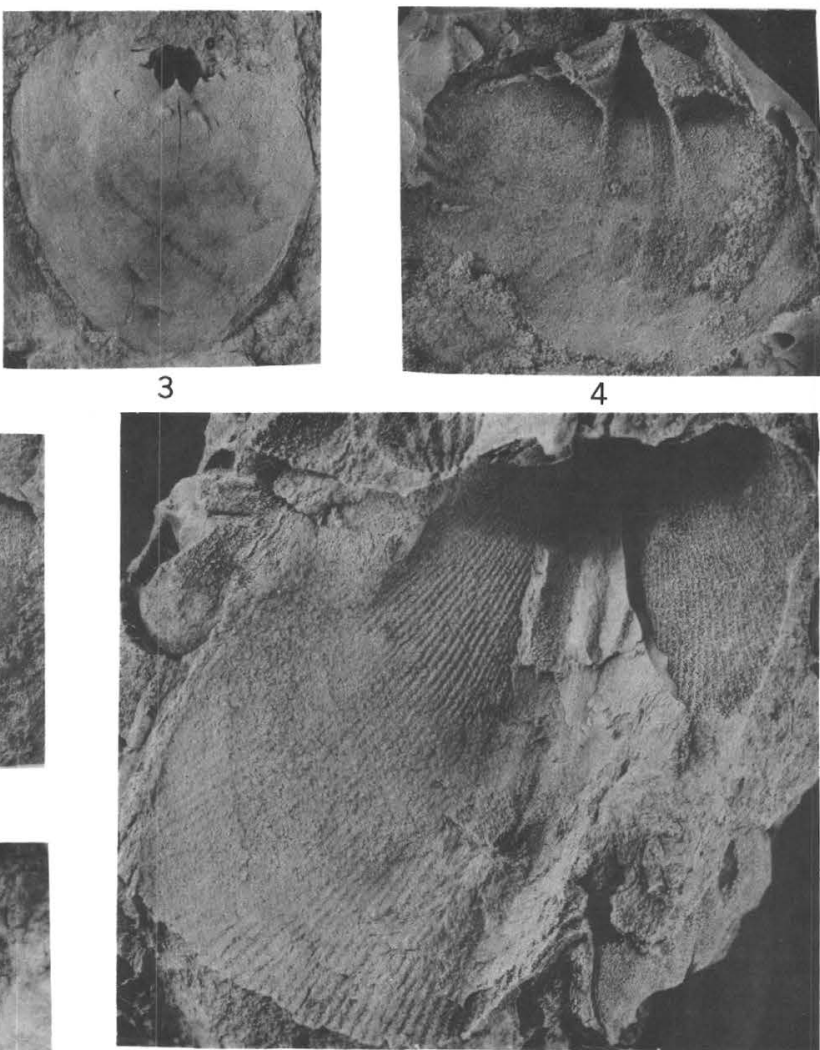

5

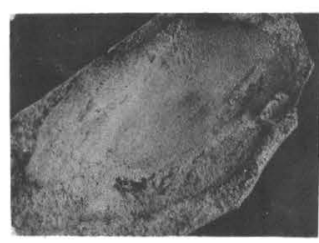

13

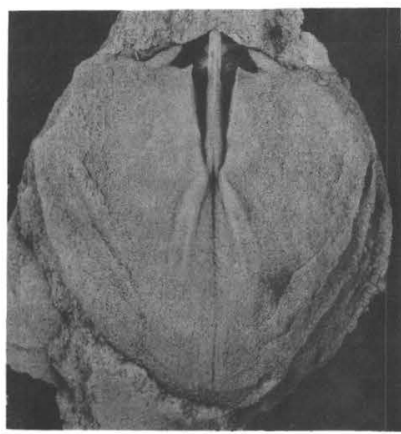

18
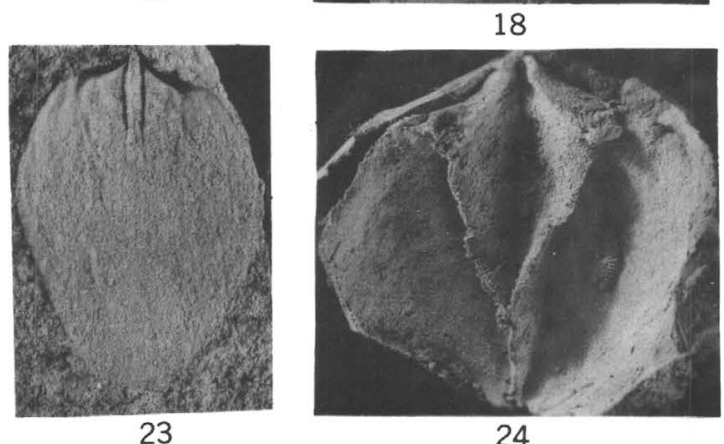

BEACHIA, CLOUDOTHYRIS, AND AMPHIGENIA 


\section{PLATE 23}

FIGURES 1-5. Globithyris callida (Clarke, 1907) (p. 72).

Tomhegan Formation. Brassua Lake quadrangle, Somerset County, Maine.

1. Exterior of pedicle valve $(X 1)$. USNM 126165A. USGS loc. 2713-SD.

2. Anterior view of interior of shell $(\times 5)$. USNM 126180. USGS loc. 2713-SD.

3. Exterior of brachial valve $(\times 2)$. USNM 126165B. USGS loc. 2713-SD.

4. Interior view of brachial valve $(\times 5)$. USNM 126180. USGS loc. 2713-SD.

5. Impression of interior of brachial valve $(\times 2)$. USNM 67778. East side of Brassua Lake opposite inlet of Moose River.

6-13. Globithyris diania (Clarke, 1907), (p. 73).

Tomhegan Formation. Brassua Lake quadrangle, Somerset County, Maine.

6. Impression of interior (posterior view $\times 1$ ). USNM 126182. USGS loc. 2869-SD.

7-11. Impression of interior: brachial valve, pedicle valve, side, posterior, and anterior views $(\times 2)$. USNM 126164B. USGS loc. 2869-SD.

12, 13. Impression and latex replica of interior of brachial valve ( $\times 2$ ). USNM 126167A. USGS loc. 2715-SD.

14-26. Mutationella parlinensis Boucot, Caster, Ives, and Talent, 1963. (p. 73).

Lower sandstone of Tarratine Formation. USGS loc. 2718-SD,

Long Pond quadrangle, Somerset County, Maine.

14-18. Impression of interior: posterior $(X 2)$, pedicle valve $(X$ $1)$, side $(\times 1)$, anterior $(\times 1)$, and brachial valve $(\times 2)$ views. Holotype, USNM 126178A.

19. Impression of interior of brachial valve $(\times 2)$. USNM $126168 \mathrm{~A}$.

20. Latex replica of exterior of pedicle valve $(\times 1)$. USNM $126173 \mathrm{~B}$.

21. Latex replica of exterior of brachial valve $(\times 2)$. USNM 126186.

22, 26. Latex replica and impression of interior of pedicle valve $(\times 2)$. USNM 126166B.

23, 25. Latex replica $(X 3)$ and impression $(X 2)$ of interior of pedicle valve. USNM 126171.

24. Impression of interior of brachial valve $(\times 2)$. USNM $126185 \mathrm{~A}$. 


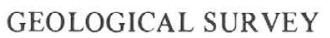

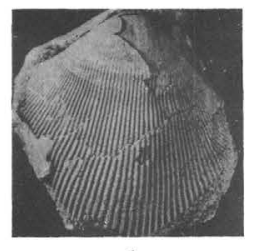

1
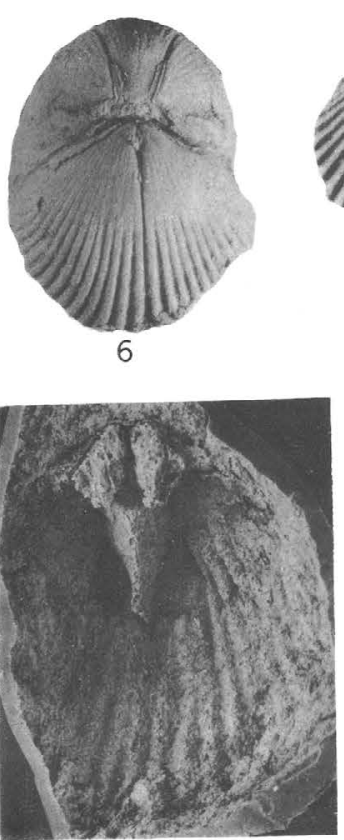

13
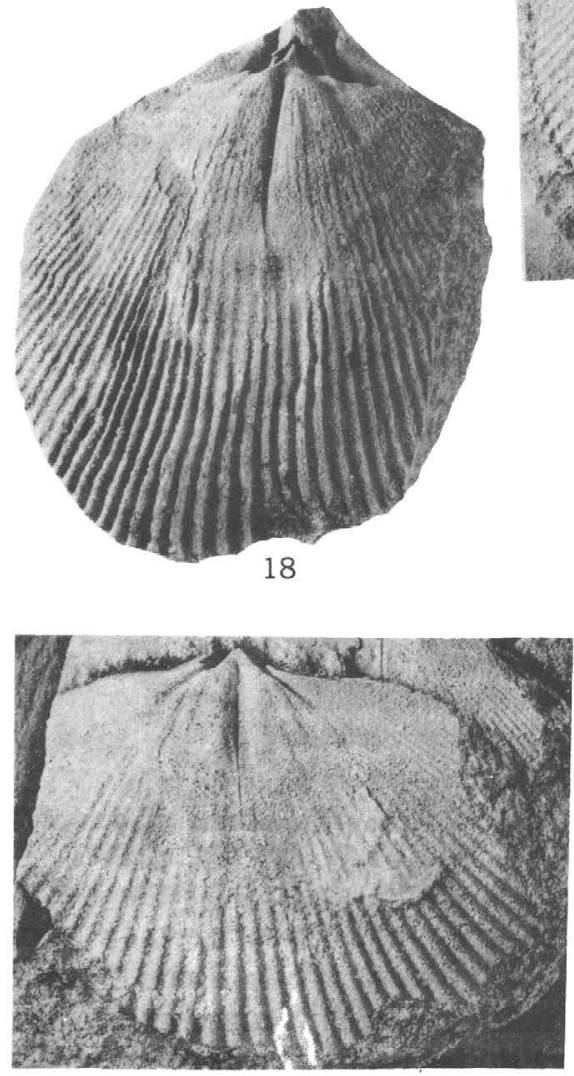

$\angle 4$

2

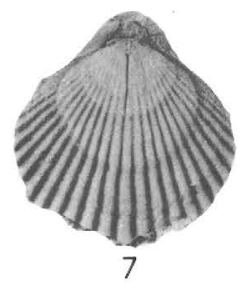

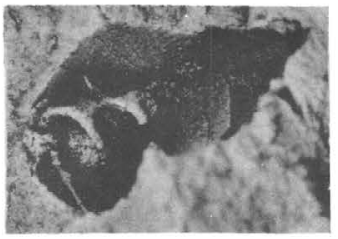
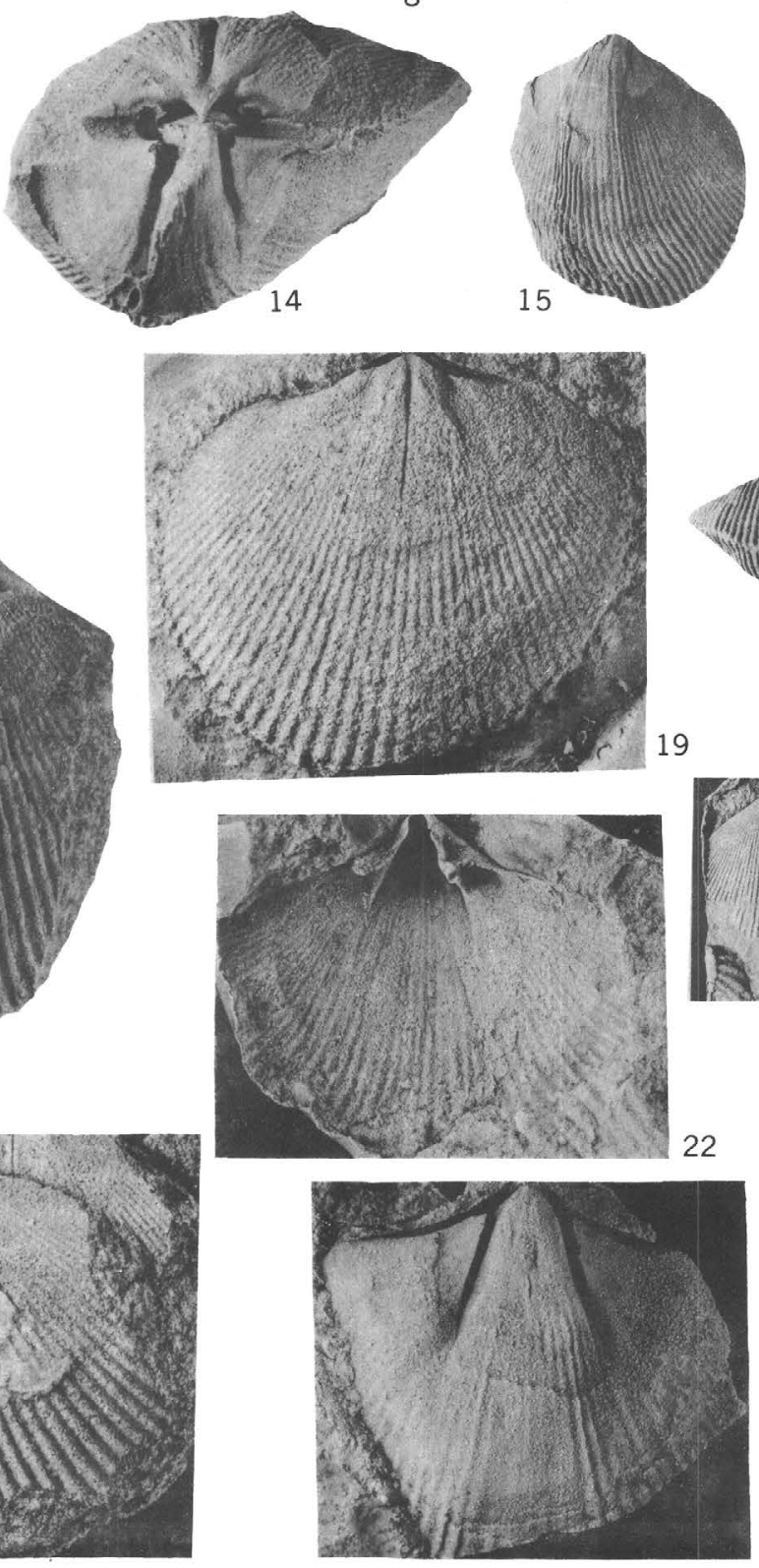

25

PROFESSIONAL PAPER 784 PLATE 23

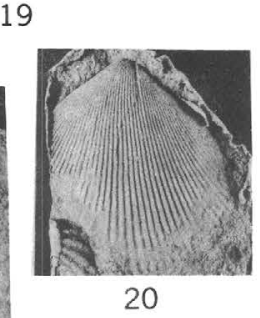

22
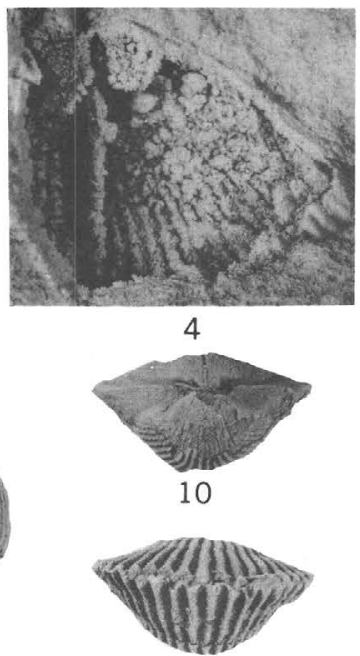

11

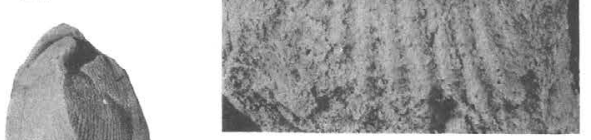

12

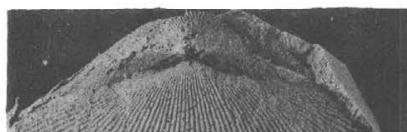

16

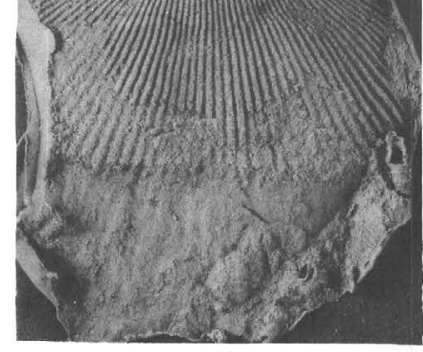

21

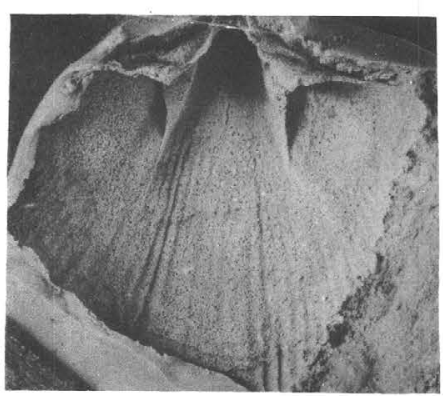

23

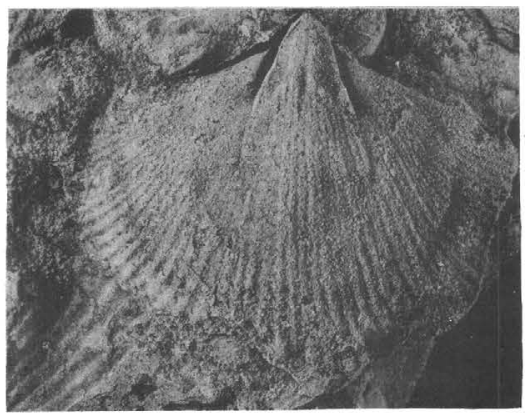

26

GLOBITHYRIS AND MUTATIONELLA 
